\title{
Науково-технічний журнал
}

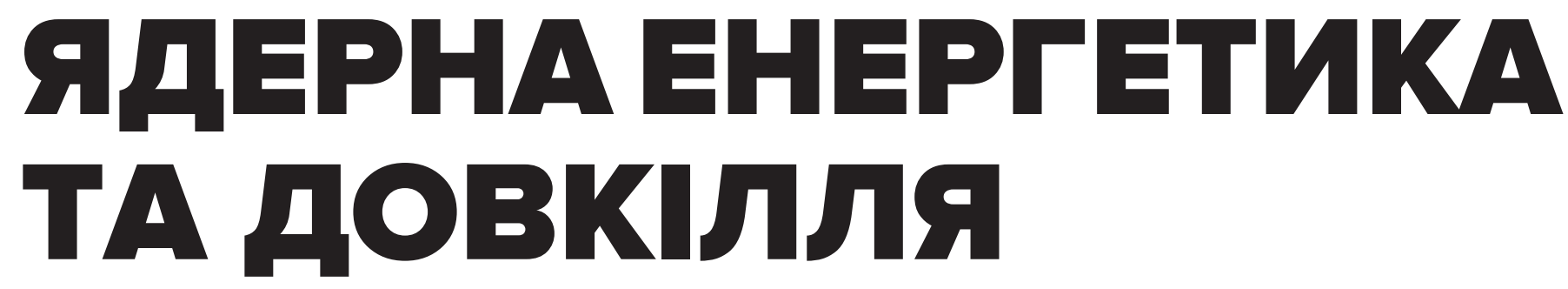

\section{NUCLEAR POWER AND THE ENVIRONMENT}

\section{№ 1 (13) 2019}

\section{Співзасновники:}

ДП «Державний науково-інженерний центр систем контролю та аварійного реагування» (ДП «ДНІЦ СКАР») Інститут проблем безпеки атомних електростанцій Національної академії наук України (ІПБ АЕС НАН України) ГО «Українське ядерне товариство»

\section{Виходить 4 рази на рік}

Свідоцтво про державну реєстрацію друкованого засобу масової інформації Серія КВ № 23679-13519ПР від 20.12.2018 p.

Видання входить до затвердженого Департаментом атестації кадрів МОН України переліку фахових видань (Наказ Міністерства освіти і науки України № 1528 від 29.12.2014 р.)

\section{Адреса редакції:}

Інститут проблем безпеки атомних електростанцій НАН України, 03028, м. Київ, вул. Лисогірська, 12, тел.: (044) 525-24-72.

E-mail: i.kutsyna@ispnpp.kiev.ua,o.a.purtov@gmail.com

Затверджено до друку вченою радою Інституту проблем безпеки атомних електростанцій НАН України (протокол № 3 від 19.04.2019)

Підписано до друку 17.05.2019. Формат 60×90 1/8. Папір крейдяний. Друк офсет. Умов. друк. арк. 11,2 Тираж 200 пр. Зам. № 18

Віддруковано в ТОВ «Календар ТМ», 02099, м. Київ, вул. Бориспільська, 9.
Головний редактор

Носовський А. В., чл.-кор. НАН України, д-р техн. наук, проф. (ІПБ АЕС НАН України)

\section{Заступники головного редактора}

Щербін В. М., канд. фіз.-мат. наук (ІПБ АЕС НАН України), Масько О. М., канд. хім. наук (ДП «ДНІЦ СКАР»)

\section{Редакційна колегія}

Бондарьков М. Д., д-р техн. наук (ДНДУ «Чорнобильський центр з проблем ядерної безпеки, радіоактивних відходів та радіоекології), Борисенко B. I., д-р техн. наук (ІПБ АЕС НАН України), Васильченко В. М., канд. техн. наук (ДП «ДНІЦ СКАР»), Габєлков С. В., д-р фіз.-мат. наук (ІПБ АЕС НАН України), Дубковський В. О., Д-р техн. наук, проф. (ОНПУ), Інюшев В. В., канд. техн. наук (ДП «ДНІЦ СКАР»), Кравченко В. П., д-р техн. наук, проф. (ОНПУ), Корольов О. В., д-р техн. наук, проф. (ОНПУ), Куи В. М., канд. фіз.-мат. наук (ДП «ДНІЦ СКАР»), Новосьолов Г. М., канд. фіз.-мат. наук (ДП «ДНІЦ СКАР»), Прістер Б. С., акад. УААН, д-р біол. наук, проф. (ІПБ АЕС НАН України),

Протасов О. О., д-р біол. наук, проф., Інститут гідробіології НАН України

Пшинко Г. М., д-р хім. наук (ІКХХВ ім. А. В. Думанського НАН України)

Рязанов В. В., д-р фіз.-мат. наук (ІЯД НАН України), Талерко М. М., д-р техн. наук (ІПБ АЕС НАН України), Шараєвський I. Г., д-р техн. наук (ІПБ АЕС НАН України), Hyatt N., PhD, BSc, проф. (Ун-т Шеффілда, Велика Британія), Pretzsch G., Dr., (GRS, Німеччина),

Schillebeeckx P., Dr., (JRC, Бельгія),

Washiya T., Dr., (JAEA, Японія)

Відповідальні секретарі Куичина I. В. (ІПБ АЕС НАН України), Пуртов О. А., канд. фіз.-мат. наук (ДП «ДНІЦ СКАР»)

Комп'ютерна верстка Куциної I. В., Толкач О. П.

(c) ДП «Державний науково-інженерний центр систем контролю та аварійного реагування», 2019

(C) Інститут проблем безпеки АЕС НАН України, 2019 (C) ГО «Українське ядерне товариство», 2019 
Gulik V. I., Pavlovych V. M.

The development of neutron-physical model for two-zone research subcritical reactor for nuclear waste transmutation

Борисенко В. I., Горанчук В. В., Піонтковський Ю. Ф., Тітімецьь I. O. Результати валідації розрахункових кодів SCALE i MCNP на даних критичних бенчмарк-експериментів на установці SF-9.

Матченко Т. І. , Верюжська Т. Ю., Сирота Н. О., Шаміс Л. Б.

Аналіз міцності захисної оболонки реактора протягом зміни температури та тиску, спричинених аварією.

Куров В. А., Посох В. О., Пирогов Т. В. Разработка и реализация компенсирующих мероприятий по обеспечению сейсмостойкости оборудования и трубопроводов систем, важных для безопасности 33

Матченко T. I.

Визначення реологічних змін полімерних каналів арматурних канатів

Mykhailov O. V., Krasnov V. O., Bezmylov V. M. Theoretical and practical aspects of using scaling factor method to characterize operational solid radioactive waste producible at nuclear power plants

ОльховикЮ. О., Федоренко Ю. Г., Розко А. М., Саєнко С. Ю., Шкуропатенко В. А. Цементування боратвмісних рідких радіоактивних відходів за підвищеної температури

Максименко А. М., Бондарьков М. Д., Осколков Б. Я., Сейда В. А., Дубас В. Н. Результаты исследований трудноизмеряемых радионуклидов в металле демонтируемого оборудования Чернобыльской АЭС и оценка коэффициентов масштабирования.

Шинкаренко В. К., Кашпур В. О., Скоряк Г. Г., Свирид О. А.

Новий безпечний конфайнмент і радіоактивні аерозолі в ближній зоні Чорнобильської атомної електростанції.

Лагуненко А. С., Хан В. Е., Одиниов А. А., Ковальчук В. П., Кравчук Т. А., Калиновский А. К., Кашпур В. А., Свирид А. А., Ткач А. В., Юрчук С. В. Радиоактивные аэрозоли около скопления лавообразных топливосодержащих материалов в помещении 012/7 объекта «Укрытие» в 2017-2018 гг. .
Gulik V. I., Pavlovych V. M.

The development of neutron-physical model for two-zone research subcritical reactor for nuclear waste transmutation 6

Borysenko V. I., Goranchuk V. V., Piontkovskyi Yu. F., Titimets I. O.

Validation results of scale and MCNP calculation codes on data of benchmark critical experiments at SF-9 intransmutation.

Matchenko T. I., Veryuzhskaya T. Yu.,

Sirota N. O., Shamis L. B.

Analysis of the strenght of the protective shell of the reactor with the change of temperature and pressure caused by the accident

Kurov V. O., Posokh V. O., Pirogov T. V.

Development and implementation of compensating activities for providing the seismic resistance of equipment and pipelines of systems important for safety 33

Matchenko T. I.

Determination of relogic changes

of polymeric channels of armature hands 42

Mykhailov O. V., Krasnov V. O., Bezmylov V. M.

Theoretical and practical aspects of using scaling factor method to characterize operational solid radioactive waste producible at nuclear power plants

Olkhovik Yu. A., Fedorenko Yu. G.,

Rozko A. N., SaenkoS. Yu., Shkuropatenko V. A.

Cementation of boron-containing liquid

radioactive waste at elevated temperature 59

Maksymenko A. M., Bondarkov M. D., Oskolkov B. Ya., Seida V. A., Dubas V. N.

Results for studies of hard-to-measure radionuclides in the metal of Chornobyl nuclear power plant equipment being dismanlted, and estimation of scaling factor ...

Shynkarenko V. K., Kashpur V. A., Skorjak G. G., Svirid A. A.

New safe confinement and radioactive aerosols in short-range region of Chornobyl nuclear power plant. 76

Lagunenko A. S., Khan V. E., Odintsov O. O., Kovalchuk V. P., Kravchuk T. A., Kalinovskiy A. K., Kashpur V. O., Svirid O. A., Tkach A. V., Yurchuk S. V. Radioactive aerosols in 2017-2018 near lava-like fuel contained materials in premise $012 / 7$

of the Shelter object 83

Author Guidelines 91 


\section{Шановні читачі!}

Наприкінці 2018 р. було проведено засідання робочої групи представників Державного підприємства «Державний науково-інженерний центр систем контролю та аварійного реагування» (ДП «ДНІЦ СКАР»), Інституту проблем безпеки атомних електростанцій Національної академії наук України (ІПБ АЕС НАН України) та Громадської організації «Українське ядерне товариство» (ГО «УкряТ»), на якому було ухвалено рішення щодо спільного випуску науково-технічного журналу «Ядерна енергетика та довкілля». Це рішення було оформлено відповідним протоколом, який був підписаний директором ДНІЦ СКАР Васильченком В. М., директором ІПБ АЕС НАН України Носовським А. В. та головою УкрЯТ Муляром Г. М. Після підготовки необхідних документів 20.12.2018 р. було отримано свідоцтво про державну реєстрацію друкованого засобу масової інформації.

Окрім зміни співвласників журналу, до яких тепер належить і ІПБ АЕС НАН України, ухвалено новий склад редакційної колегії, до якого увійшли фахівці з провідних наукових установ України та зарубіжжя. Видавцем журналу обрано ДНІЦ СКАР, головним редактором - А. В. Носовського, заступниками головного редактора - В. М. Щербіна та О. М. Масько, відповідальними секретарями - I. В. Куцину та О. А. Пуртова.

3 метою розширення можливостей для ознайомлення фахівців та громадськості із науковими досягненнями в галузі ядерної енергетики журнал публікуватиме науково-дослідні, інженерно-технічні та експертно-аналітичні статті з напрямів: загальні питання ядерної енергетики, безпека ядерних установок, поводження з відпрацьованим ядерним паливом та радіоактивними відходами, зняття з експлуатації ядерних установок, об’єкт «Укриття», екологічна безпека.

До друку приймаються раніше неопубліковані авторські статті, що відповідають профілю видання та мають наукове та практичне значення. Порядок публікації в журналі передбачає обов’язкове рецензування, що здійснюється членами редакційної колегії або запрошеними фахівцями. 3 метою входження журналу до провідних міжнародних баз даних матеріали супроводжуватимуться розширеними анотаціями англійською мовою та списком використаної літератури, оформленим відповідно до міжнародних стандартів. Кожна наукова стаття матиме власний цифровий ідентифікатор DOI.

Відповідно до політики відкритого доступу електронна версія кожного випуску після виходу у світ розміщуватиметься на офіційному сайті журналу www.npe.org.ua.

Основна мета видання журналу - інформувати наукову громадськість і фахівців ядерної галузі про нові результати досліджень і робіт у галузі безпеки ядерних технологій.

Раніше журнал «Ядерна енергетика та довкілля» видавався вже понад сім років і за цей час зарекомендував себе як науково-технічне видання з питань радіаційної фізики, ядерної, радіаційної та екологічної безпеки, радіаційного матеріалознавства, безпеки та надійності ядерно-енергетичних установок, аналітичної та радіаційної хімії, використання нанотехнологій, IT-технологій та промислових технологій тощо і став настільною книгою для багатьох профільних фахівців.

Оновлена редакційна колегія, як і раніше, планує публікувати в журналі аналітичні огляди, результати досліджень у галузі безпеки атомних електростанцій, а також інших об’єктів, на яких використовуються джерела іонізуючого випромінювання. Наукові публікації будуть орієнтовані, в першу чергу, на виявлення дефіцитів безпеки і розробку науково обгрунтованих заходів щодо підвищення рівня безпеки на етапах проектування, будівництва, введення в експлуатацію, експлуатації, подовження ресурсу експлуатації, зняття з експлуатації ядерних установок, об'єктів, призначених для поводження з відпрацьованим ядерним паливом, радіоактивними відходами та іншими джерелами іонізуючого випромінювання.

Стратегією розвитку паливно-енергетичного комплексу України до 2030 р. передбачається подальший розвиток ядерно енергетичної складової. Перед галуззю стоять такі важливі завдання, як: будівництво нових 
ядерних установок, подовження ресурсу експлуатації діючих енергоблоків АЕС, підвищення ї безпеки; зняття з експлуатації енергоблоків Чорнобильської АЕС, зокрема перетворення об’єкта «Укриття» на екологічно безпечну систему; поводження з радіоактивними відходами та відпрацьованим ядерним паливом, а також їх остаточне захоронення та багато інших.

Для реалізації стратегічних завдань ядерної галузі необхідні кваліфіковані кадри, здатні не тільки експлуатувати ядерні установки, але й займатися питаннями їх проектування, будівництва, налагодження, ремонту й зняття з експлуатації, а також забезпечувати якісне регулювання ядерної та радіаційної безпеки. Нині в Україні, як і в багатьох інших країнах, відчувається нестача кваліфікованих фахівців. На атомних електростанціях та підприємствах ядерного профілю створюються і діють внутрішні структури з підготовки персоналу, до яких входять навчально-тренувальні центри, аналітичні тренажери, курси підвищення кваліфікації тощо. Таким чином, для більшості підприємств збереження й передання накопичених знань i практичного досвіду вже стали необхідною реальністю.

Завдання збору, збереження й передання ядерних знань в Україні є актуальними не тільки для галузевих структур, що опікуються питаннями розвитку ядерних технологій, але й для багатьох інших відомств і організацій, пов’язаних із цією тематикою, у тому числі й вищих навчальних закладів, які готують фахівців-ядерників. Однією з важливих складових системи управління ядерними знаннями є публікація інформації про появу нових знань у засобах масової інформації, орієнтованих на спеціальну аудиторію, у нашому випадку на фахівців і наукових співробітників, які професійно опікуються проблемами безпеки ядерних технологій.

Редакційна колегія планує публікувати наукову і технічну інформацію з теорії загальної безпеки, фізики активних зон реакторів, термогідравлічних процесів, імовірнісного аналізу безпеки, радіаційного захисту, матеріалознавства і конструкційної надійності обладнання, поводження з ядерними матеріалами, радіоактивними відходами та джерелами іонізуючих випромінювань. Особлива увага буде приділятися науковим публікаціям з питань перетворення об’єкта «Укриття» на екологічно безпечну систему.

На сторінках видання вітчизняні та зарубіжні фахівці можуть викладати свою точку зору стосовно спірних питань безпеки, регламентації радіаційних впливів, радіаційного захисту, а також результатів вивчення наслідків аварій та інцидентів. Журнал також займатиме активну позицію у висвітленні найбільш актуальних філософських і концептуальних питань з ядерної та радіаційної безпеки і принципово важливих 3 практичної точки зору проблем, пов'язаних з аваріями на Чорнобильській AЕС, на АЕС Фукушіма, методології оцінок рівня безпеки тощо.

Заповнюючи прогалину, що виникла через брак наукових знань із цієї тематики, журнал буде узагальнювати міжнародний і національний досвід забезпечення безпеки під час проектування, ліцензування, експертизи, будівництва, експлуатації і зняття з експлуатації об’єктів, що використовують ядерні технології.

Редакційна колегія сподівається, що журнал стане професійним науково-технічним виданням, призначеним для фахівців атомних електростанцій, інших підприємств і організацій, що займаються питаннями безпеки, викладачів, аспірантів, студентів вишів, наукових працівників. Він виконуватиме просвітницьку роль, формуючи у читачів об'єктивні, засновані на наукових даних і досвіді уявлення про реальний сучасний рівень безпеки ядерних технологій, визначаючи таким чином ставлення різних груп населення, громадських організацій, політиків і законодавців до атомної енергетики. Видання прагне займати об’єктивну і неупереджену позицію в складній проблемі забезпечення безпеки, активно пропагуючи рекомендації МАГАТЕ та інших міжнародних організацій.

Об’єктивно відображати досягнення в галузі безпеки ядерних технологій, радіаційного захисту та охорони навколишнього середовища означає забезпечувати тим самим сучасною науковою інформацією широке коло фахівців, які працюють у цих галузях.

У світі наукових журналів існує певне упередження, коли редактори видань не схильні публікувати результати досліджень, що спростовують раніше отримані результати. Основна мета багатьох відомих журналів полягає в інформуванні наукової громадськості про нові відкриття, а не про рутинні дослідження, які повторюють раніше проведені експерименти і дають при цьому менш цікаві результати. Тому рецензенти здебільшого відмовляють авторам критичних статей у публікації, що в свою чергу призводить до того, що багато нових результатів залишаються невідомими для наукової громадськості. 
3 огляду на це наш журнал приймає до публікації не тільки статті, в яких наводяться нові результати досліджень у галузі ядерної енергетики, але й ті, в яких описано добре продумані плани майбутніх досліджень ще до отримання їх остаточних результатів, проміжні результати, а також статті з критикою раніше виконаних досліджень. Редакційна колегія з розумінням ставиться до молодих науковців і студентів вищих навчальних закладів, приймаючи до публікації результати їх ще не зовсім зрілих робіт, у тому числі й оглядово-постановочні статті.

Маю впевненість, що і в майбутньому наукове і практичне значення видання буде зміцнюватись $\mathrm{i}$ зростати в інтересах безпеки людства і навколишнього природного середовища.

Головний редактор, чл.-кор. НАН України, д-р техн. наук, проф. Анатолій Носовський 


\author{
V. I. Gulik ${ }^{1}$, V. M. Pavlovych ${ }^{2}$ \\ ${ }^{1}$ Institute for Safety Problems of Nuclear Power Plants, NAS of Ukraine, 12, Lysogirska st., Kyiv, 03028, Ukraine \\ ${ }^{2}$ Institute for Nuclear Research of NAS, 47, Nauky av., Kyiv, 03680, Ukraine
}

\title{
The Development of Neutron-Physical Model for Two-Zone Research Subcritical Reactor for Nuclear Waste Transmutation
}

Keywords:

Accelerator Driven Systems, subcritical system, transmutation of nuclear waste, optimization of subcritical core.

\begin{abstract}
The creation of small-scale research subcritical reactors is necessary, in particular, for the development of the technology for nuclear waste transmutation in Accelerator Driven Systems. The construction of such facilities will allow the development of the technology of nuclear waste transmutation without constructing an expensive industrial scale subcritical reactor. The low-cost neutron generator can serve as a driver for such research subcritical reactors. A two-zone model of subcritical system driven by high-intensity neutron generator is proposed in this work. The proposed system can use two separated cores with different neutron spectra: fast and thermal. This paper also represents the main stages of the proposed model of two-zone subcritical reactor development. The results of simulations, aimed at optimizing of the geometry and fuel composition of the two-zone subcritical system, performed in Serpent and MCNP codes are presented. An overview of the analysis of different facilities that can be used as an external neutron source for subcritical reactor is shown, however a high-intensity neutron generator based on $\mathrm{D}$ - $\mathrm{T}$ reaction was chosen as the optimal neutron source for low-cost research subcritical reactor for investigation of nuclear waste transmutation. Generally, it is observed that the two-zone subcritical system can effectively amplify neutron flux from external neutron sources.
\end{abstract}

\section{Introduction}

After Three Mile Island accident in the United States (1979), the Chornobyl disaster in Ukraine (1986) and Fukushima Daiichi disaster in Japan (2011), the safe operation of nuclear reactors has become a very controversial topic. Since the mid-twentieth century the huge quantity of spent nuclear fuel and vitrified nuclear waste obtained by the operation of conventional nuclear reactors has been accumulated. Currently, many countries have still not implemented a strategy for dealing with spent nuclear fuel and nuclear waste management. On the other hand, there are also some countries (such as Sweden and Finland) which adopted a strategy for the final disposition of spent nuclear fuel in deep geological repositories, but so far there is no existing storage of spent nuclear fuel or nuclear waste for a long-term period with the exception of the experimental facility in Sweden.

Over the past twenty years the possibility of solving nuclear waste problem by means of nuclear waste transmutation has been heavily investigated [1-3]. The nuclear waste can be divided into two main categories: minor actinides and long-lived fission products [4]. The minor actinides include isotopes such as: ${ }^{237} \mathrm{~Np},{ }^{241} \mathrm{Am},{ }^{243} \mathrm{Am}$, ${ }^{244} \mathrm{Cm}$ etc. The transmutation of minor actinides occurs mainly as a result of fission reaction. As shown in number studies, the most favorable conditions for minor actinides transmutation are observed in fast neutron spectrum [5]. Therefore, the fast reactors or the subcritical systems driven by an external neutron source with sufficiently high neutron energy (Accelerator Driven Systems (ADS)) are considered to be the most realistic scheme

(C) V. I. Gulik, V. N. Pavlovych, 2019 
for minor actinides transmutation. On the other hand, the long-lived fission products include some of the following isotopes: ${ }^{129} \mathrm{I},{ }^{99} \mathrm{Tc},{ }^{99} \mathrm{Zr},{ }^{135} \mathrm{Cs},{ }^{126} \mathrm{Sn}$ etc. The long-lived fission products transmutation occurs mainly as a result of capture reaction. It has been found in several studies that the most favorable conditions for transmutation of long-lived fission products are observed in the thermal neutron spectrum $[6,7]$. However, the transmutation of long-lived fission products in the traditional critical reactors is complicated due to a number of technical issues. Therefore, the subcritical systems with thermal neutron spectrum are a great option to investigate long-lived fission products transmutation.

The development of neutron-physical model of twozone research subcritical reactor driven by high-intensity neutron generator for investigations of minor actinides and long-lived fission products transmutation has been described in the present paper.

\section{Model development}

\section{High-intensity D-T neutron generator as a driver for subcritical core}

The analysis of the latest research of subcritical systems driven by external neutron source (Fig. 1) helps to summarize what type of facilities of external neutron source could be used:

1. The proton (cyclotron or linear) accelerator that uses spallation reactions to produce neutron flux in the subcritical reactor [8]. Advantage: high intensity of neutron source; disadvantages: high cost and difficulties in beam-window construction. MYRRHA project in the European Union [9] can be given as an example to this type of facility.

2. Electron accelerators that use photon-neutron reactions to produce neutron flux in the subcritical reactor [10]. Advantage: the possibility to obtain sufficiently high current of electrons and therefore the relatively high intensity of neutron source; disadvantage: high cost. An example of this type of facility is the KIPT neutron source facility in Kharkiv, Ukraine [11].

3. High-intensity neutron generator and plasma focusing (PF) devices that use deuterium-tritium (D-T) reactions to produce neutron flux in the subcritical reactor [12-14]. Advantages: relatively low cost and well-known technology; disadvantages: relatively low intensity of neutron source and necessity to have tritium producing facility. A good example is the YALINA-booster facility in Belarus [15].

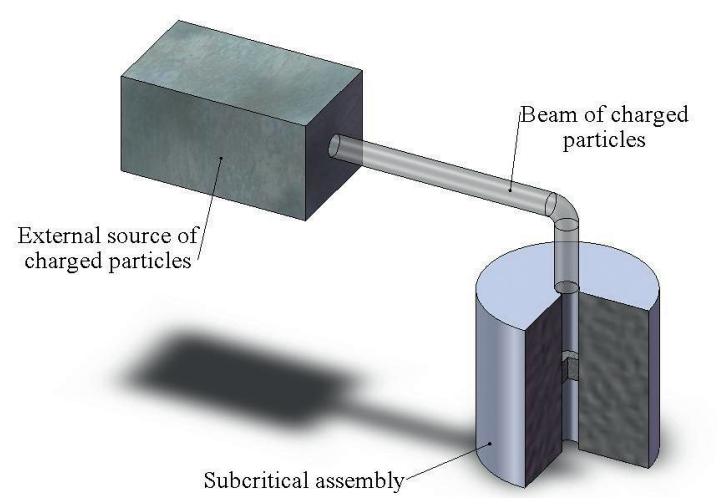

Fig. 1. Simple scheme of ADS

4. Fusion neutron sources based on the fusion reaction to produce neutrons in the subcritical reactor [16]. Advantage: high intensity of neutron source; disadvantages: still under development, so not ready for immediate use.

In the condition of limiting funds, such as in Ukraine at present time, it is impossible to develop and construct the expensive high current proton and electron accelerators, so the option of D-T neutron source is an optimal solution for the development of experimental facilities for the investigation of nuclear waste transmutation in such cases.

Another useful feature of the proposed subcritical reactor is the existence of two cores with different neutron spectra in a single facility (fast and thermal). There are two major advantages in such a two-zone subcritical system: 1) the ability of more effectively enhancing the neutron flux from the external source [17];2) the fact that it is very convenient to investigate transmutation of minor actinides and long-lived fission products, due to the existence of fast and thermal neutron spectra in a single facility $[5,6]$.

\section{The using of MCNP Monte Carlo code for model development}

The investigations of two-zone subcritical system driven by high-intensity neutron generator were performed in Institute for Nuclear Research in Kyiv, Ukraine, whose scientists had a big experience in high intensity neutron generators design and production [18], as well as in study of neutron flux amplification in subcritical assemblies of different types and different material composition [19-22]. The neutron and energy amplification factor were selected as basic parameters for this study. 
The neutron codes MCNP-4c and SCALE-5 as well as ENDF/B-VI nuclear data library were used for the simulation stage [23].

Thereafter, the research of amplifying abilities of two-zone subcritical system, geometrical optimization and optimization of material composition of such systems were performed [24-27]. It has been found that two-zone subcritical system can more effectively amplify the neutron flux from external source than one-zone subcritical system, from the point of view of neutron economy. The optimal geometric and material characteristics for inner and outer zones of subcritical reactor also were established.

Nuclear waste transmutation was simulated using codes MCNP, ORIGEN and Monteburns for developed MCNP model of two-zone subcritical reactor. The transmutation of main minor actinides in the inner zone with fast neutron spectrum was carried out along with the transmutation of main long-lived fission products in the outer zone with thermal neutron spectrum. The main results for the modeling of nuclear waste transmutation were presented in our previous publications $[28,29]$.

The diagram of the final version of MCNP code model is presented in Fig. 2. The overall conditions for the present MCNP model were:

1) geometry and material parameters of fuel elements for VVER-1000 reactor;

2) the fuel in pins - uranium dioxide with different enrichments for ${ }^{235} \mathrm{U}$ (in inner zone - $15 \%$, in outer zone - $4 \%$ );

3) fuel density - $10.96 \mathrm{~g} / \mathrm{cm}^{3}$;

4) cladding material - zirconium $+1 \%$ niobium;

5) hexagonal lattice of fuel elements was used in both zones;

6) coolant of inner zone is helium whereas coolant of outer zone is light water;

7) the effective neutron multiplication factor is 0.97. The ENDF/B-VI nuclear reaction database containing evaluated (recommended) cross sections was also used for MCNP calculations.

In addition, there are also MCNP visualizations for the developed two-zone subcritical model which are presented in Figs. 3-6.

\section{Serpent Monte Carlo code for model development}

The second stage of the presented work was the model development of the two-zone research subcritical reactor driven by high-intensity neutron generator

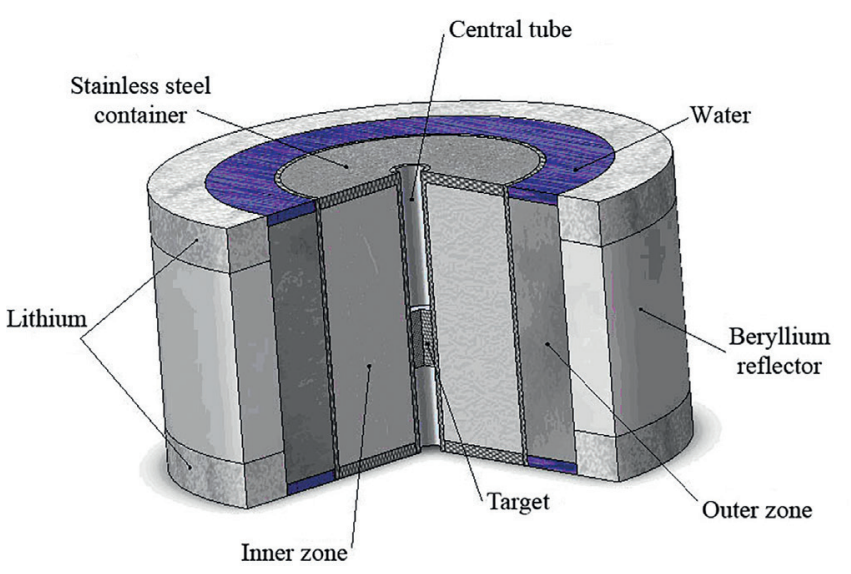

Fig. 2. Diagram of the two-zone subcritical reactor model developed by MCNP code

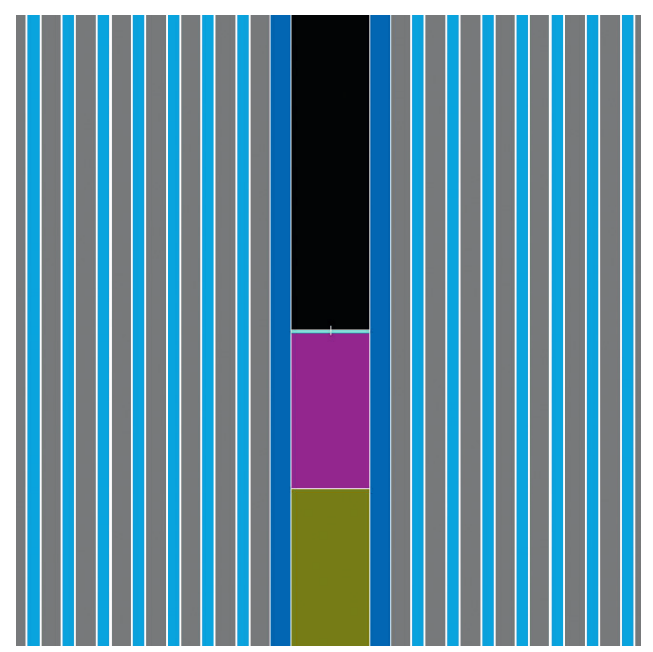

Fig. 3. Vertical cross-section view of central part for calculated model in MCNP code

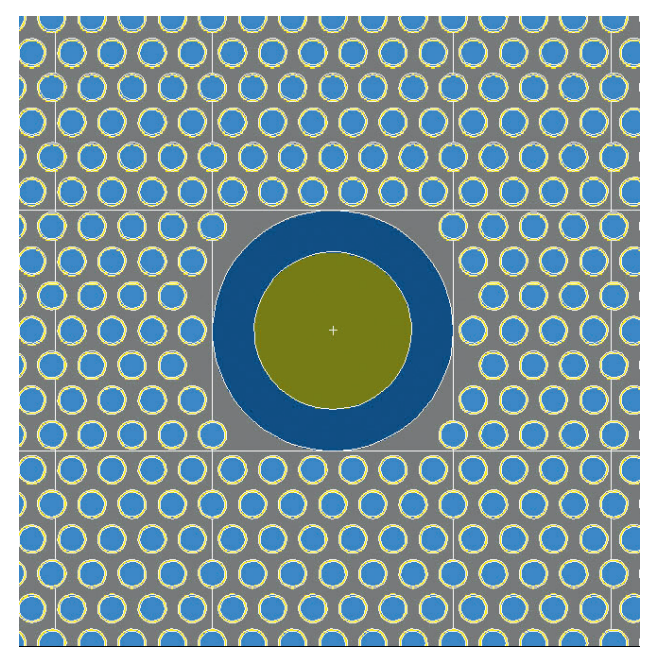

Fig. 4. Horizontal cross-section view of central part for calculated model in MCNP code 


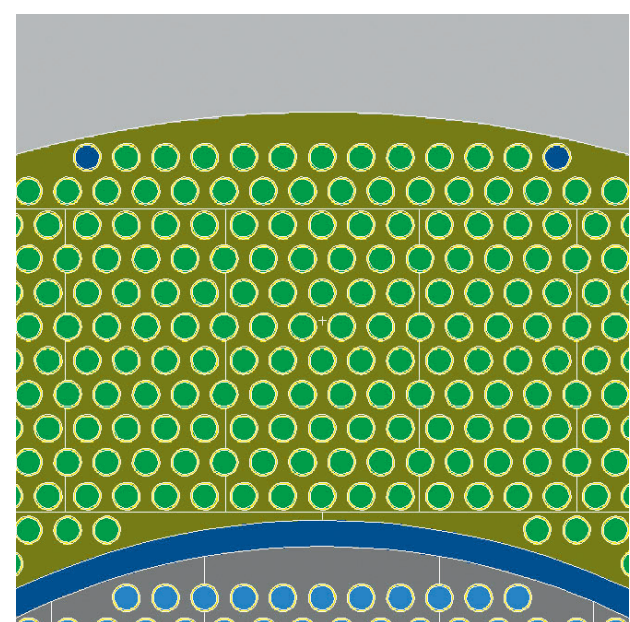

Fig. 5. Horizontal cross-section view of outer zone for the calculated model in MCNP code

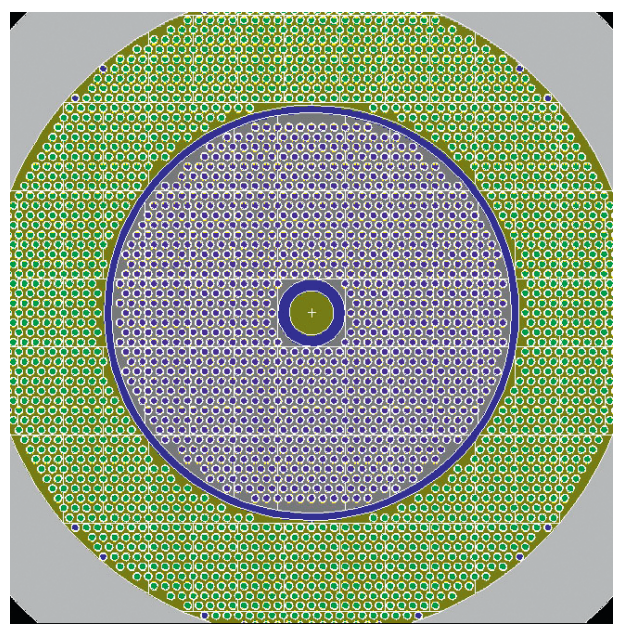

Fig. 6. Horizontal cross-section view of the whole core for the calculated model in MCNP code

using new Monte Carlo Serpent code [30]. Serpent code has been developed in Finland in VTT Technical Research Centre since 2004. There are two main advantages of studying the subcritical systems in Serpent Monte Carlo code: i) the possibility of modeling of a subcritical system with external neutron source and ii) the possibility of burnup calculation for the simulation of nuclear waste transmutation.

The first modelling results of the two-zone subcritical system with uranium dioxide for homogeneous case with the help of the Serpent code were presented in our previous publication [31]. Additional calculation results of the modelled homogeneous subcritical system with uranium metallic fuel without coolant and cladding materials are also presented in this paper. The diagram of the final version of Serpent code model is shown in
Fig. 7 and visualization Serpent code is displayed in Fig. 8. The typical conditions for the present Serpent model were: 1) homogenizing fuel - uranium metallic with different enrichments for ${ }^{235} \mathrm{U}$ (in inner zone $20 \%$, in outer zone $-4 \%$ ); 2) fuel density $-19.07 \mathrm{~g} / \mathrm{cm}^{3}$; 3) effective neutron multiplication factor set to 0.97. The ENDF/B-VII nuclear data library was used for Serpent calculations.

The optimization results of the two-zone subcritical system with heterogeneous fuel were presented in our previous work [32] with the help of Serpent simulation.

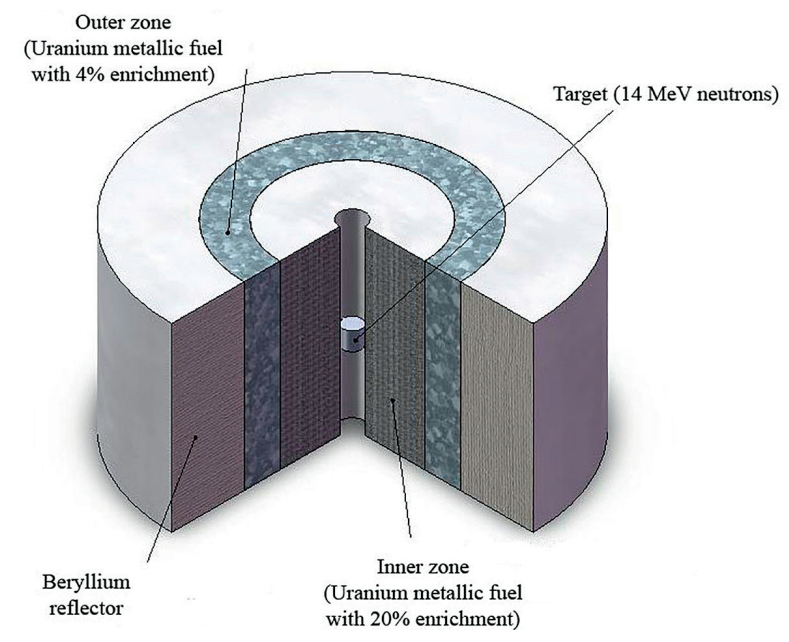

Fig. 7. Diagram of the two-zone subcritical reactor model for homogeneous systems

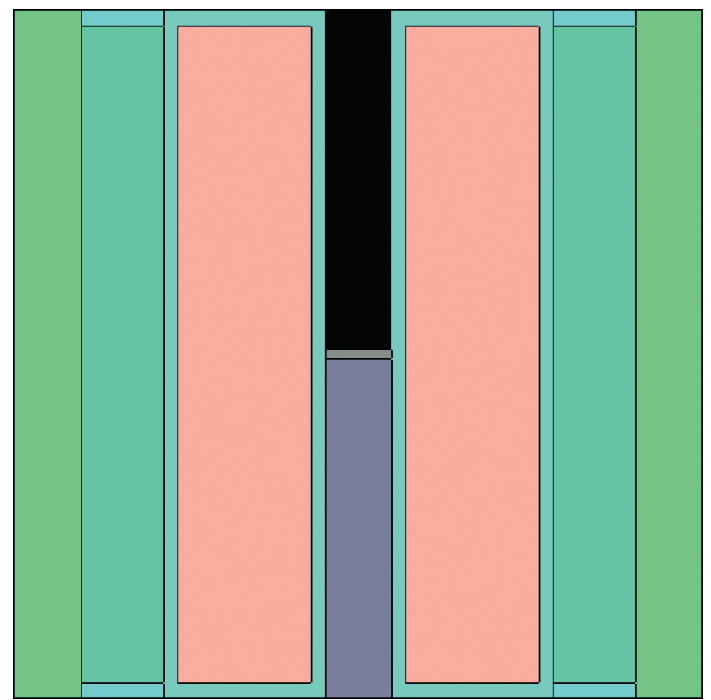

Fig. 8. The scheme of the calculated homogeneous model in Serpent code 


\section{MCNP and Serpent modelling results}

\section{The modelling of transmutation characteristics for two-zone subcritical system}

Homogeneous mixture of uranium metallic enriched in ${ }^{235} \mathrm{U}$ for $20 \%$ in the inner zone and a homogeneous mixture of uranium metallic with $4 \%$ enrichment in ${ }^{235} \mathrm{U}$ in the outer zone were considered as fuel material in the present model. Zones have neither coolant nor cladding materials, therefore both zones have fast neutron spectrum in neutron-physical model. Other characteristics for this case are presented in section 2.3. The Serpent code was used for this modelling.

The following are some of the additional parameters in the developed model:

diameter of the target is $5 \mathrm{~cm}$;

thickness of stainless steel container wall is $1 \mathrm{~cm}$;

thickness of the beryllium reflector is $5 \mathrm{~cm}$;

diameter-to-height ratio of subcritical core is 1 for minimization of the leakage of neutrons;

neutron source is isotropic point sources with

$14 \mathrm{MeV}$ monoenergetic neutrons;

effective neutron multiplication factor is 0.97 ;

total number of source neutrons is 50,000 ;

number of batches is 500 .

The seven two-zone subcritical systems with different geometrical parameters were analyzed as well as the onezone subcritical system that was calculated for comparison. Every two-zone system has varied radius of the inner zone given ranging from 9.5 to $15.5 \mathrm{~cm}$. The radius of the outer zone was selected in such a way that $k_{\text {eff }}$ of all system is equal to 0.97 and in a way to provide a diameter-to-height ratio equal to 1 . Radioactive isotopes ${ }^{237} \mathrm{~Np}$ and ${ }^{243} \mathrm{Am}$ were chosen as the examples of nuclear waste for the investigation of transmutation characteristics. The volume normalized neutron flux integrated over space and energy (Flux), fission microscopic cross-section $\left(\sigma_{f}\right)$, capture microscopic cross-section $\left(\sigma_{c}\right)$ and ratio of these cross-sections $(\alpha)$ are used as main parameters in this work [5]. The fission microscopic cross-section $\left(\sigma_{f}\right)$ is the microscopic cross-section of fission reaction for the chosen isotopes $\left({ }^{237} \mathrm{~Np}\right.$ and $\left.{ }^{243} \mathrm{Am}\right)$ averaged by inner or outer zones. The capture microscopic cross-section $\left(\sigma_{c}\right)$ is the microscopic cross-section of capture reaction for the chosen isotopes $\left({ }^{237} \mathrm{~Np}\right.$ and ${ }^{243} \mathrm{Am}$ ) averaged by inner or outer zones. In addition, the value $(\alpha)$ is the ratio of the average capture to fission cross section for the chosen isotopes $\left({ }^{237} \mathrm{~Np}\right.$ and $\left.{ }^{243} \mathrm{Am}\right)$ in the inner or outer zones [5]. Finally, the value $(\alpha)$ is useful for un- derstanding transmutation potential of subcritical systems that are being analyzed. The optimal conditions of the two-zone subcritical system with respect to the transmutation efficiency (Flux and $\alpha$ ) were defined as the main goal for the present calculation results.

Figs. 9-22 represent the modelling results for homogeneous mixture of uranium metallic in the inner zone enriched to $20 \%$ and in the outer zone enriched to $4 \%$ for ${ }^{235} \mathrm{U}$. The data in the figures are laid out with the data on the ordinate and the radius of the inner zone in the abscissa, in the two-zone subcritical system. The certain square marker (point) on figures correspond to the one-zone subcritical system and they are represented in the figures for comparison.

First, we analyzed the change of the neutron flux in inner and outer zones (see Figs. 9 and 10) in case of changing the inner zone radius (and as the result, the volume of more enriched uranium).

Fig. 10 represents a natural increase for the neutron flux in outer zone in case of increasing the volume of inner zone due to increasing the amount of more enriched uranium ( $20 \%$ for $\left.{ }^{235} \mathrm{U}\right)$ in inner zone. And Fig. 9 shows the peak of the neutron flux with the radius of inner zone of approximately $14 \mathrm{~cm}$. This indicates that it is possible to choose the ratio of the volumes of both zones so that the neutron fluxes in inner and outer zones would be maximum and, as a result, the number of neutrons that can be used for the transmutation of minor actinides would be higher.

Then we investigated the transmutation characteristics of inner and outer zones with respect to the chosen isotopes which belong to minor actinides: ${ }^{237} \mathrm{~Np}$ and ${ }^{243} \mathrm{Am}$. We attributed the fission microscopic cross section, as the cross section of the most important process

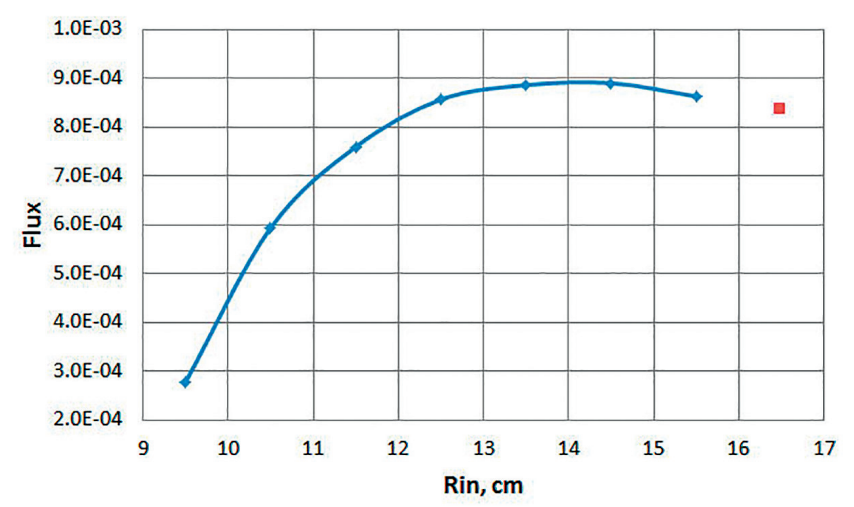

Fig. 9. The volume normalized neutron flux integrated over space and energy for inner zone 


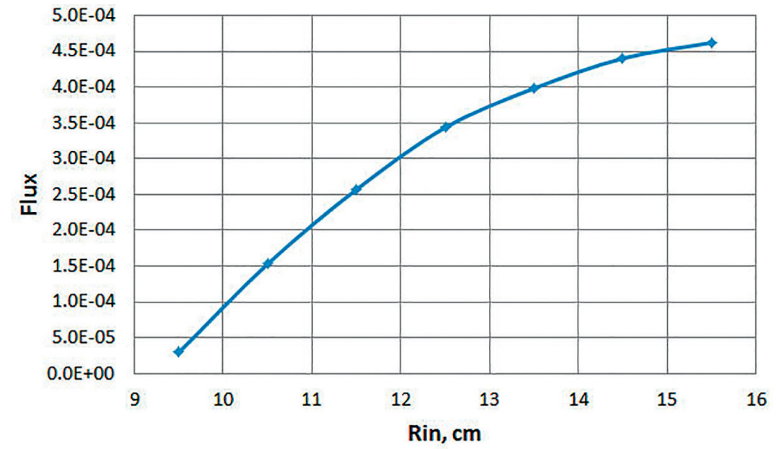

Fig. 10. The volume normalized neutron flux integrated over space and energy for outer zone

for the transmutation of minor actinides, to the transmutation characteristics. The capture microscopic cross section is important since the capture reaction plays the role of a competing process with respect to fission and significantly affects the "economy" of neutrons. The ratio of these two cross sections is an excellent indicator of the transmutation potential of the reactor; it was proposed by Massimo Salvatores in [5].

Microscopic cross sections of fission and capture in inner zone for ${ }^{237} \mathrm{~Np}$ and ${ }^{243} \mathrm{Am}$ are presented in Figs. 11-14. In case of increasing the volume of inner zone with more enriched uranium, the possibility of fission naturally increases for both isotopes. For capture cross section it is possible to choose the optimal volume ratio of both zones at which the probability of a capture reaction will be minimal. For both isotopes, the optimal volume ratio of inner and outer zones occurs when the radius of inner zone is approximately $13 \mathrm{~cm}$.

Figs. 15-18 show fission and capture microscopic cross sections in outer zone for ${ }^{237} \mathrm{~Np}$ and ${ }^{243} \mathrm{Am}$. The fission and capture cross sections for outer zone increase in case of increasing the volume of inner zone. As a result, a change in the geometric parameters of outer zone does not allow optimizing the transmutation characteristics of the two-zone subcritical system.

Figs. 19-22 show the ratios of capture and fission microscopic cross sections in inner and outer zones for ${ }^{237} \mathrm{~Np}$ and ${ }^{243} \mathrm{Am}$. Figures 19 and 20 show that it is possible to choose such a ratio of the volumes of inner and outer zones at which the probability of transmutation for both ${ }^{237} \mathrm{~Np}$ and ${ }^{243} \mathrm{Am}$ will be maximum. This optimal volume ratio is observed when the radius of inner zone is approximately $13-14 \mathrm{~cm}$ for both isotopes. For outer zone, it is slightly different (Figs. 21 and 22), here in case of decreasing the volume of outer zone, the probability of transmutation of the chosen isotopes will decrease. But at the same time, with optimal radii for inner zone, it is possible to

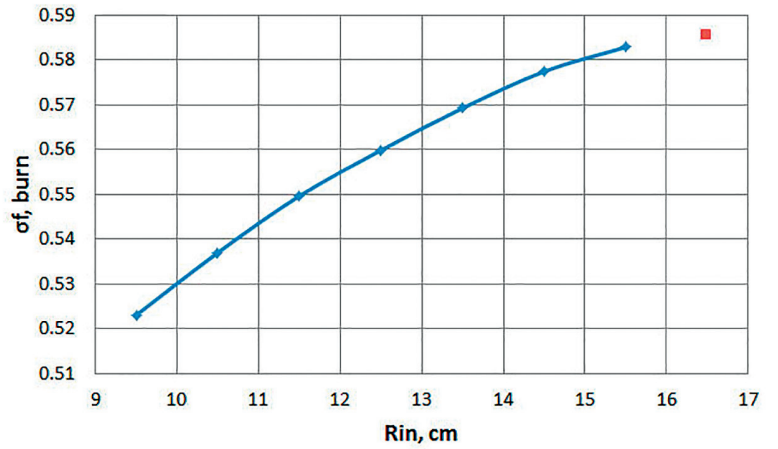

Fig. 11. The fission microscopic cross-section of ${ }^{237} \mathrm{~Np}$ for inner zone

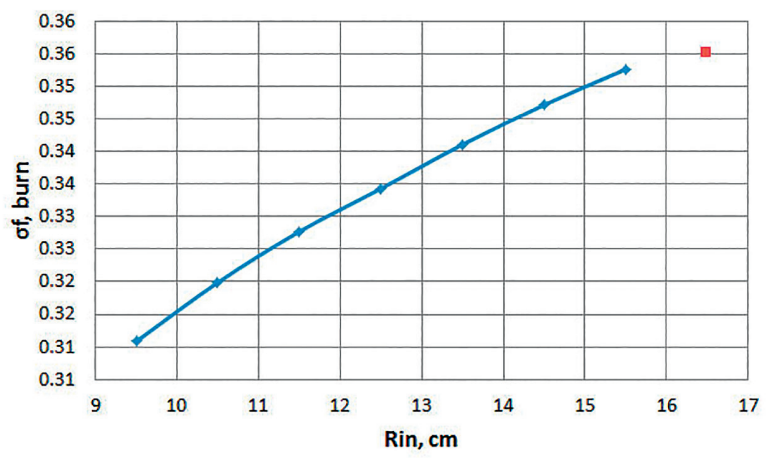

Fig. 12. The fission microscopic cross-section of ${ }^{243} \mathrm{Am}$ for inner zone

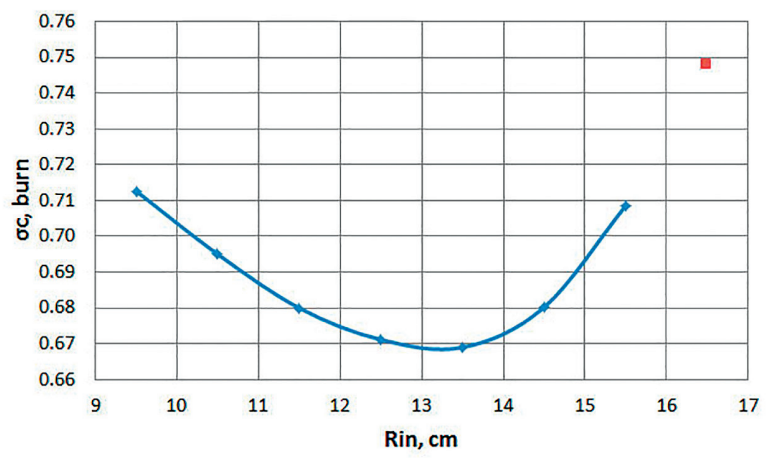

Fig. 13. The capture microscopic cross-section of ${ }^{237} \mathrm{~Np}$ for inner zone

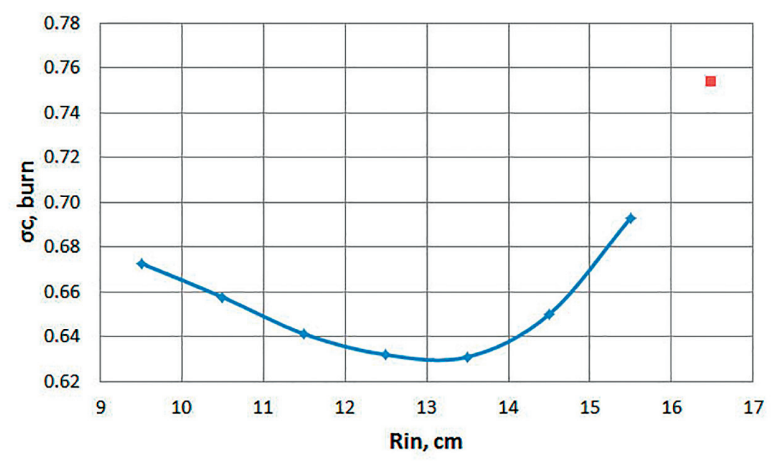

Fig. 14. The capture microscopic cross-section of ${ }^{243} \mathrm{Am}$ for inner zone 


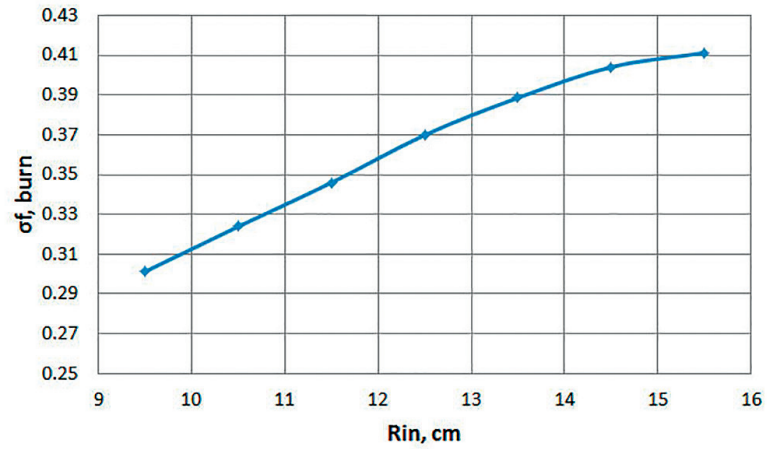

Fig. 15. The fission microscopic cross-section of ${ }^{237} \mathrm{~Np}$ for outer zone

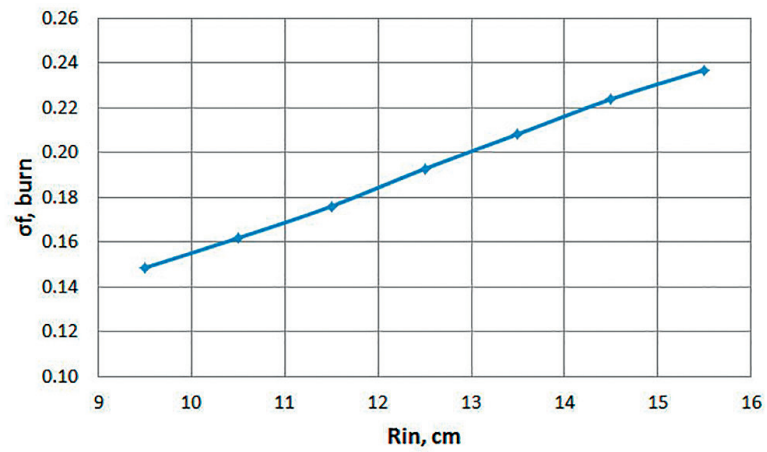

Fig. 16. The fission microscopic cross-section of ${ }^{243} \mathrm{Am}$ for outer zone

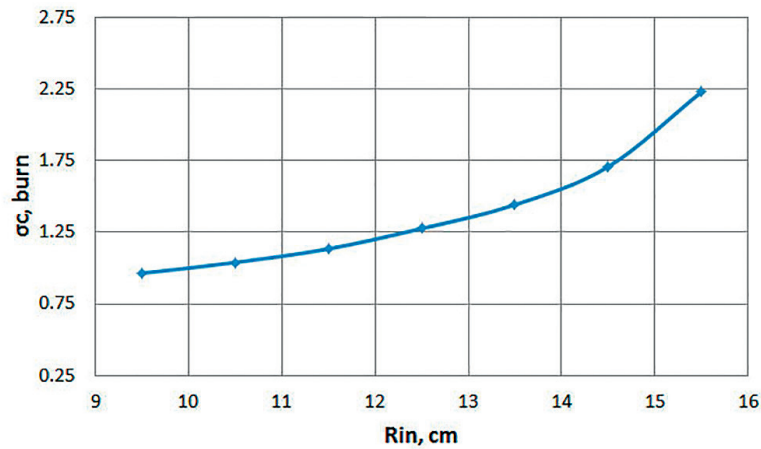

Fig. 17. The capture microscopic cross-section of ${ }^{237} \mathrm{~Np}$ for outer zone

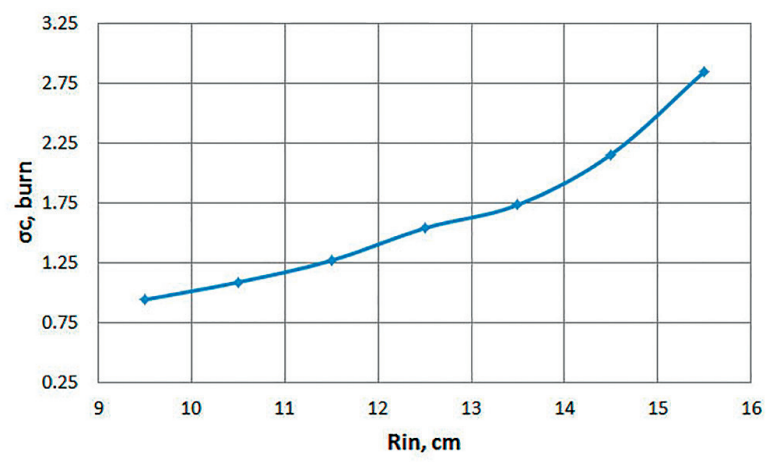

Fig. 18. The capture microscopic cross-section of ${ }^{243} \mathrm{Am}$ for outer zone

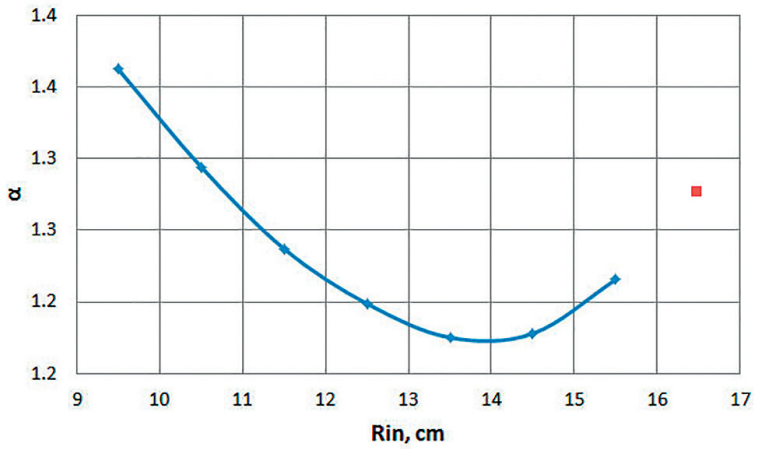

Fig. 19. The ratio of the average capture to fission cross section of ${ }^{237} \mathrm{~Np}$ in the inner zone

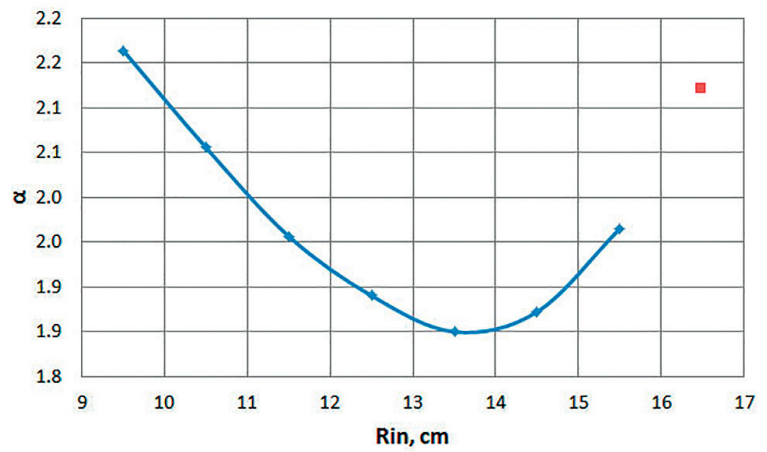

Fig. 20. The ratio of the average capture to fission cross section of ${ }^{243} \mathrm{Am}$ in the inner zone

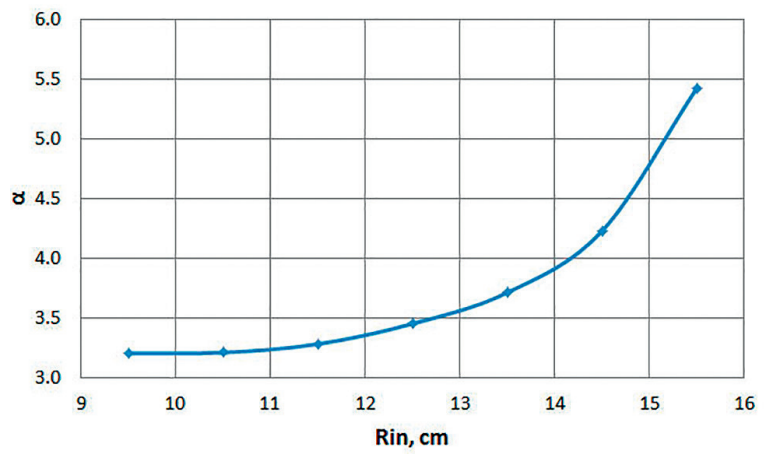

Fig. 21. The ratio of the average capture to fission cross section of ${ }^{237} \mathrm{~Np}$ in the outer zone

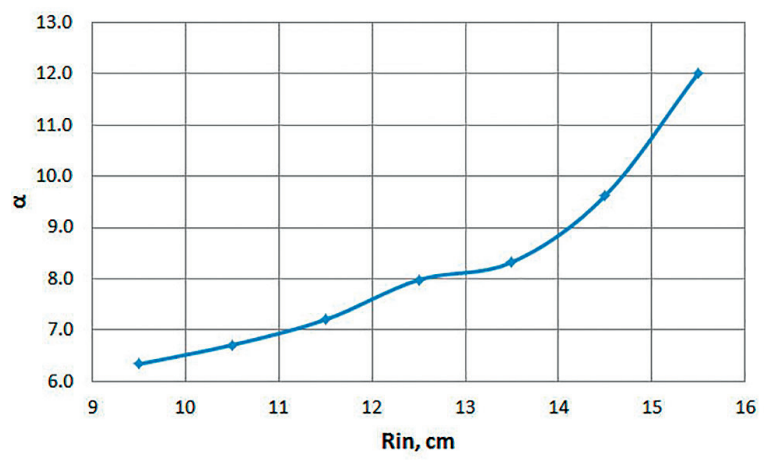

Fig. 22. The ratio of the average capture to fission cross section of ${ }^{243} \mathrm{Am}$ in the outer zone 
maintain acceptable values of the ratios of capture and fission microscopic cross sections for outer zone.

The presented modelling results show that even a simple distribution of materials with different nuclear properties (different enrichment for ${ }^{235} \mathrm{U}$ ) in the core can have an effect on the transmutation characteristics of the system. In this case, it is possible to choose the ratios of the volumes of different materials in such a way that these characteristics are optimal. Also, such a distribution of different materials may, if necessary, reduce the cost of a subcritical reactor due to a more efficient arrangement of highly enriched uranium. The presented example of division into subzones with different materials can be applied in the internal "fast" zone of the subcritical reactor shown in Fig. 2.

The Figs. 10, 14, 15, 20 and 21 display the optimal fuel composition for two-zone subcritical reactor from a viewpoint of transmutation efficiency for minor actinides. The optimization research presented in our previous publication [32] showed that the optimal fuel composition could be obtained for two-zone subcritical reactor from fuel cost perspective. The presented calculation results for two-zone homogeneous subcritical system without coolant and cladding materials could be a good basis for the development of effective heterogeneous model for future research in subcritical reactor systems.

\section{The energy-release calculations for two-zone subcritical system}

If we return to the model of a reactor with separate zones with fast and thermal neutron spectra, then it is of interest to consider the distribution of energy-release in the active core composed of two zones with different neutron spectra.

The energy-release calculations for two-zone subcritical system described in Chapter 2.2 were estimated with the help of the developed MCNP model. The total energy-release within the entire subcritical system was found to be $412.67 \mathrm{~kW}$ (for intensity of neutron generator = $1 \cdot 10^{13}$ neutron/s), while the energy-release in inner zone was found to be $70.85 \mathrm{~kW}$ and the energy-release in outer zone was $341.82 \mathrm{~kW}$. The energy-release $(Q)$ for each pin located on $\mathrm{x}$ axis from the target to the beryllium reflector (see Figs. 3-6) is presented in Fig. 9. The energy-release $(Q)$ in subcritical reactor was calculated with taking into account total neutron fissions in the core, averaged energy release from fission (about $200 \mathrm{MeV}$ ) and intensity of neutron generator (in this case $=1 \cdot 10^{13}$ neutron $/ \mathrm{s}$ ).

From Fig. 23 we can identify which pin's layer has the maximum and minimum of energy-release. It is clear that pins in outer zone possess higher energy-release due to thermal neutron spectrum. In addition, it can also be noted that the thermal neutron spectrum has influence on inner zone where pins 13 and 14 have higher energy-release compared with the other pins in inner zone.

From Fig. 23 we can see that the average energy-release, and as a result, the fuel burn-up in outer ("thermal") zone is about five times higher than the average energy-release in inner ("fast") zone. This may conduct additional difficulties in the operation of the future two-zone subcritical reactor.

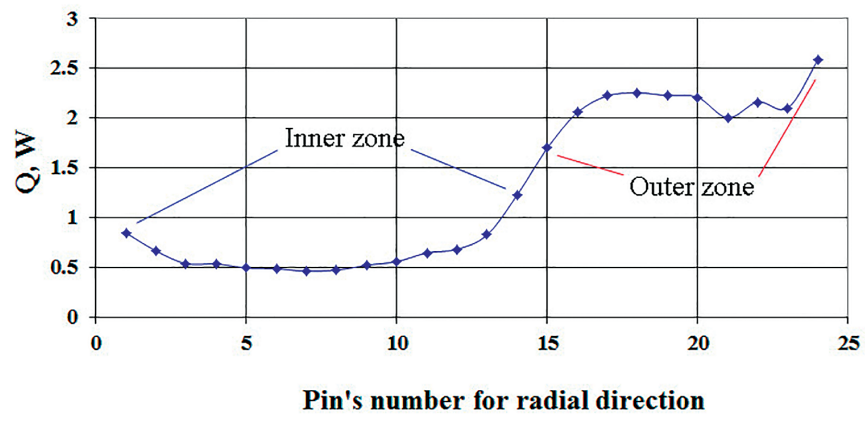

Fig. 23. The energy-release for individual pin located on $\mathrm{x}$ axis for radial direction versus the pin's number

\section{Conclusions}

This paper presents the idea behind the development of the two-zone subcritical research reactor driven by high-intensity neutron generator for investigation of nuclear waste transmutation along with the methodology and results of the performed simulations by various Monte Carlo codes.

The neutron-physical model of the presented subcritical reactor with the help of MCNP and Serpent Monte Carlo codes was developed and the energy-release calculations with the help of MCNP model were carried out.

The microscopic fission cross-section, microscopic capture cross-section and ratio of these cross-sections for ${ }^{237} \mathrm{~Np}$ and ${ }^{243} \mathrm{Am}$ were estimated for the developed model. It was found that there is an optimal value of ratio of inner zone volume to outer zone volume from the viewpoint of transmutation efficiency for minor actinides.

This research was carried out with the financial support of the State Projects of the National Academy of Sciences of Ukraine "Study of nonlinear and stochastic properties of multiplying nuclear systems" (State number: 0111U001944) and "The neutron distribution and 
the investigations of neutron-physical behavior for different types of nuclear reactors" (State number: 0106U005599). We acknowledge support from State Project of the National Academy of Sciences of Ukraine for young scientists "The investigation of optimal geometric and material characteristics for two-zone subcritical reactor driven by external neutron source" (State number: 0111U007144). This research was carried out with the financial support of the IAEA Coordinated Research Project (CRP) "Accelerator Driven Systems (ADS) Applications and use of Low-Enriched Uranium in ADS (T33002)" within the project 'The Two-Zone Subcritical Systems with Fast and Thermal Neutron Spectra for Transmutation of Minor Actinides and Long-Lived Fission Products'.

\section{References}

1. IAEA-TECDOC-985. Accelerator Driven Systems: Energy Generation and Transmutation of Nuclear Waste. Status report. Vienna: IAEA, 1997, 482 p.

2. A European Roadmap for Developing Accelerator Driven Systems (ADS) for Nuclear Waste Incineration. The European Technical Working Group on ADS, 2001, 145 p.

3. Salvatores M. (2006) Fuel Cycle Strategies for the Sustainable Development of Nuclear Energy: The Role of Accelerator Driven Systems. Nuclear Instruments and Methods in Physics Research A, vol. 562, pp. 578-584.

4. Taczanowski S. (2003) Transmutations of Nuclear Waste in Accelerator-Driven Subcritical Systems. Applied Energy, vol. 75, pp. 97-117.

5. Salvatores M. (2002) The Physics of Transmutation in Critical or Subcritical Reactors. C. R. Physique, vol. 3, pp. 999-1012.

6. Salvatores M. (2002) Transmutation: Issues, Innovative Options and Perspectives. Progress in Nuclear Energy, vol. 40, pp. 375-402.

7. Yang W. S., Kim Y., Hill R. N., Taiwo T. A., Khalil H. S. (2004) Long-Lived Fission Product Transmutation Studies. Nuclear Science and Engineering, vol. 146, pp. 291-318.

8. Jongen Y. et al. (2002) High-Intensity Cyclotrons for Radioisotope Production and Accelerator Driven Systems. Nuclear Physics, vol. 701, pp. 100-103. doi: 10.1016/S03759474(01)01555-X.

9. Abderrahim H., Baeten P., Bruyn D., Fernandez R. (2012) MYRRHA - A Multi-Purpose Fast Spectrum Research Reactor. Energy Conversion and Management, vol. 63, pp. 4-10. https://doi.org/10.1016/j.enconman.2012.02.025.

10. Gohar Y. et al. (2006) Accelerator-Driven Subcritical Facility: Conceptual Design Development. Nuclear Instruments and Methods in Physics Research A, vol. 562, pp. 870-874.

11. Zhong Z., Gohar Y., Talamo A. (2011) Analysis of Fuel Management in the KIPT Neutron Source Facility. Annals of Nuclear Energy, vol. 5, pp. 1014-1022.
12. Verbeke J. M., Leung K. N., Vujic J. (2000) Development of a Sealed-Accelerator-Tube Neutron Generator. Applied Radiation and Isotopes, vol. 53, pp. 801-809.

13. Markovskij D. V. et al. (2001) Experimental Activation Study of Some Russian Vanadium Alloys with $14-\mathrm{MeV}$ Neutrons at SNEG-13 Facility. Fusion Engineering and Design, vol. 58-59, pp. 591-594.

14. Sadowski M. J., Scholz M. (2003) Comments on Status of Plasma Focus Research. Proc. Int. Workshop "Dense Magnetized Plasmas" (Warsaw, Poland, November 25-26, 2003).

15. Talamo A., Gohar Y., Sadovich S., Kiyavitskaya H., Bournos V., Fokov Y., Routkovskaya C. (2014) High enriched to low enriched fuel conversion in YALINA Booster facility. Progress in Nuclear Energy, vol. 70, pp. 43-53.

16. Stacey W. M. (2001) Capabilities of a DT Tokamak Fusion Neutron Source for Driving a Spent Nuclear Fuel Transmutation Reactor. Nuclear Fusion, vol. 41, pp. 135-154.

17. Daniel H., Petrov Yu. V. (1996) Subcritical Fission Reactor Driven by the Low Power Accelerator. Nuclear Instruments and Methods in Physics Research A, vol. 373, pp. 31-134.

18. Kolomiec N. F. (1985) Investigation and Development of Metal-Tritium Neutron-Produced Targets for Accelerators of charged particles (Ph.D. thesis). Kyiv, Institute for Nuclear Research, 156 p.

19. Gulik V. I. (2012) The Model of Two-zone Research Subcritical Nuclear Reactor driven by High-Intensity Neutron Generator (Ph.D. thesis). Kyiv, Institute for Nuclear Research, 143 p.

20. Babenko V. A., Gulik V. I., Jenkovszky L. L., et al. (2005) Study of One-zone Subcritical Amplifier of Neutron Flux Involving Enriched Uranium. Problems of Atomic Science and Technology, vol. 45, no. 6, pp. 122-126.

21. Babenko V.A., Gulik V.I., Jenkovszky L. L., Pavlovych V.M., Pupirina E. A. (2006) On the Subcritical Amplifier of Neutron Flux Based on Enriched Uranium. In: Čechák T., Jenkovszky L., Karpenko I. (eds.) Nuclear Science and Safety in Europe. Springer Heidelberg, pp. 253-263. doi: 10.1007/978-1-4020-4965-1_21.

22. Gulik V. I., Pavlovich V. N., Pupirina E. A., Babenko V. A. (2006) The Research Subcritical Reactor. Proc. Int. Conf. "Research Reactors in 21 $1^{\text {st }}$ century" (Moscow, Russia, June 20-23, 2006).

23. Briesmeister J. MCNP-A General Monte Carlo Code $N$-Particle Transport Code Version 4A, LA-12625. Los Alamos National Laboratory, 1993.

24. Babenko V. O., Gulik V. I., Pavlovych V. M., Pupirina O. M. (2006) Two-zone subcritical nuclear reactors. Problems of Nuclear Power Plants' Safety and of Chornobyl, vol. 6, pp. 8-15.

25. Babenko V. O., Gulik V. I., Pavlovych V. M. (2008) The Research Subcritical Reactor. Nuclear Physics and Atomic Energy, vol. 9, no. 1, pp. 56-61.

26. Babenko V. O., Gulik V. I., Pavlovych V. M. (2010) The New 
Research Subcritical Reactor driven by a High-intensity Neutron Generator for Transmutation of the Nuclear Waste. Proc. Int. Conf. "WM2010" (Phoenix, Arizona, US, 7-11 March, 2010).

27. Babenko V. O., Gulik V. I., Pavlovych V. M. (2012) Modeling of Two-zone Accelerator-Driven Systems. Nuclear Physics and Atomic Energy, vol. 13, no. 3, pp. 266-275.

28. Babenko V. O., Gulik V. I., Pavlovych V. M., Rybalova A. P. (2011) About Possibility of Nuclear Waste Transmutation in Subcritical System Driven by High-Intensity Neutron Generator. Problems of Nuclear Power Plants' Safety and of Chornobyl, vol. 16, pp. 8-16.

29. Babenko V. O., Gulik V. I., Pavlovych V. M. (2012) The Transmutation of Nuclear Waste in the Two-Zone Subcritical System Driven by High-Intensity Neutron Generator. Proc. Int. Conf. "WM2012” (Phoenix, Arizona, US, February 26 -March 1, 2012).

30. Leppänen J., Pusa M., Viitanen T., Valtavirta V., Kaltiaisenaho T. (2015) The Serpent Monte Carlo code: Status, development and applications in 2013. Annals of Nuclear Energy, vol. 82, pp. 142-150.

31. Gulik V., Tkaczyk A. H. (2013) Optimization of Geometry, Material and Economic Parameters of a TwoZone Subcritical Reactor for Transmutation of Nuclear Waste with SERPENT Monte Carlo Code. Proc. Int. Conf. Supercomputing in Nuclear Applications \& Monte Carlo (SNA\&MC2013) (Paris, France, October 27-31, 2013).

32. Gulik V., Tkaczyk A. H. (2014) Cost Optimization of ADS Design: Comparative Study of Externally Driven Heterogeneous and Homogeneous Two-Zone Subcritical Reactor Systems. Nuclear Engineering and Design, vol. 270, pp. 133-142.

\author{
В. І. Гулік ${ }^{1}$, В. М. Павлович ${ }^{2}$ \\ ${ }^{1}$ Iнститут проблем безпеки АЕС НАН Украӥни, \\ вул. Лисогірська, 12, м. Київ, 03028, Україна \\ ${ }^{2}$ Iнститут ядерних досліджень НАН України, \\ просп. Науки, 47, м. Київ, 03680, Украйна
}

\section{Розробка нейтронно-фізичної моделі двозонного дослідницького підкритичного реактора для трансмутації ядерних відходів}

Створення невеликих дослідницьких підкритичних реакторів необхідно, зокрема, для розробки технології трансмутації ядерних відходів у підкритичних системах, що керуються зовнішнім джерелом нейтронів. Будівництво таких установок дає змогу розробити технологію трансмутації ядерних відходів без будівництва дорогого промислового підкритичного реактора. Недорогий генератор нейтронів може служити зовнішнім джерелом нейтронів для таких дослідницьких підкритичних реакторів. У роботі запропоновано двозонну модель підкритичної системи, що керується генератором нейтронів високої інтенсивності. Така система може використовувати дві окремі зони реактора з різними нейтронними спектрами: швидким та тепловим. Представлено основні етапи розробки запропонованої моделі двозонного підкритичного реактора. Результати моделювання виконано в кодах Serpent i MCNP з метою оптимізації геометрії і складу палива у двозонній підкритичній системі. Також представлено огляд різних установок, які можуть бути використані як зовнішнє джерело нейтронів для підкритичного реактора. Однак оптимальним джерелом нейтронів для недорогого дослідницького підкритичного реактора для дослідження трансмутації ядерних відходів був обраний D-T генератор нейтронів високої інтенсивності. У цілому спостерігається, що двозонна підкритична система може ефективно посилювати потік нейтронів від зовнішніх джерел нейтронів.

Ключові слова: підкритичні системи, що керуються прискорювачами, підкритичний реактор, трансмутація радіоактивних відходів, оптимізація підкритичної зони.

\section{В. И. Гулик ${ }^{1}$, В. Н. Павлович ${ }^{2}$}

${ }^{1}$ Институт проблем безопасности АЭС НАН Украины, ул. Льсогорская, 12, г. Киев, 03028, Украина

${ }^{2}$ Институт ядерных исследований НАН Украинь, просп. Науки, 47, г. Киев, 03680, Украина

\section{Разработка нейтронно-физической модели двухзонного исследовательского подкритического реактора для трансмутации ядерных отходов}

Создание небольших исследовательских подкритических реакторов необходимо, в частности, для разработки технологии трансмутации ядерных отходов в подкритических системах, управляемых внешними источниками нейтронов. Строительство таких установок позволит разработать технологию трансмутации ядерных отходов без строительства дорогостоящего промышленного подкритического реактора. Недорогой генератор нейтронов может служить внешним источником нейтронов для таких исследовательских подкритических реакторов. В данной работе предложена двухзонная модель подкритической системы, которая управляется генератором нейтронов 
высокой интенсивности. Данная система может использовать две отдельные зоны реактора с разными нейтронными спектрами: быстрым и тепловым. Представлены основные этапы развития предлагаемой модели двухзонного подкритического реактора. Результаты моделирования выполнены в кодах Serpent и MCNP с целью оптимизации геометрии и состава топлива двухзонной подкритической системы. Представлен обзор анализа различных установок, которые могут быть использованы в качестве внешнего источника нейтронов для подкритического реактора. Однако в качестве оптимального источника нейтронов для недорогого исследовательского подкритического реактора для исследования трансмутации ядерных отходов был выбран D-T генератор нейтронов высокой интенсивности. В целом показано, что двухзонная подкритическая система может эффективно усиливать поток нейтронов от внешних источников нейтронов.

Ключевые слова: подкритические системы, управляемые ускорителями; подкритический реактор; трансмутация радиоактивных отходов; оптимизация подкритической зоны.

Надійшла 24.01.2019

Received 24.01.2019 


\author{
В. І. Борисенко ${ }^{1,2}$, В. В. Горанчук ${ }^{1}$, Ю. Ф. Піонтковський ${ }^{2}$, I. О. Тітімець ${ }^{2}$ \\ ${ }^{1}$ Інститут проблем безпеки АЕС НАН Украӥни, вул. Лисогірська, 12, м. Київ, 03028, Украӥна \\ ${ }^{2}$ Київський національний університет імені Тараса Шевченка, просп. акад. Глушкова, 4, м. Київ, 03022, Україна
}

\title{
Результати валідації розрахункових кодів SCALE i MCNP на даних критичних бенчмарк-експериментів на установці SF-9
}

Ключові слова:

ядерна безпека, критичний експеримент, твел, відпрацьоване ядерне паливо, ефективний коефіцієнт розмноження.

\begin{abstract}
Представлено результати розрахунків у кодах SCALE i MCNP критичних бенчмарк-експериментів на установці SF-9. Установка SF-9 побудована для проведення досліджень з досягнення критичності залежно від кількості твелів (типу ВВЕР1000) і рівня теплоносія (вода) у баці установки. Проведення таких досліджень $€$ обов'язковим при обгрунтуванні можливості застосування розрахункових кодів, що вибираються для аналізу ядерної безпеки технологічних операцій із переміщення, перевезення та зберігання як свіжого ядерного палива (вузол зберігання ядерного палива на енергоблоці), а також і відпрацьованого ядерного палива (контейнери перевантаження, сховища відпрацьованого ядерного палива) реакторів різних типів. Наприклад, при обгрунтуванні ядерної безпеки систем зберігання відпрацьованого ядерного палива необхідно підтвердити, що максимальне значення ефективного коефіцієнта розмноження нейтронів $k_{\text {еф }}$ нижче встановленої нормативної межі 0,95 для умов нормальної експлуатації, за порушень нормальної експлуатації та в випадку проектних аварій.

Наведено результати розрахунків $k_{\text {еф }}$ для 12 критичних експериментів на установці SF-9, що дає змогу зробити висновки стосовно похибки визначення $k_{\text {еф }}$ у кодах SCALE і MCNP, а також обгрунтовано за результатами валідації обрати розрахунковий код для проведення аналізу з ядерної безпеки систем зберігання ядерного палива, у тому числі й відпрацьованого ядерного палива.
\end{abstract}

\section{Вступ}

У статті розглядається питання процедури (обгрунтування) вибору розрахункових кодів, які рекомендовано використовувати для обгрунтування ядерної безпеки різних систем поводження 3 ядерним паливом (свіжим або відпрацьованим). Одне 3 основних завдань під час обгрунтування ядерної безпеки систем поводження з ядерним паливом $є$ підтвердження необхідної підкритичності при всіх операціях з ядерним паливом на етапах його доставки та експлуатації на AEC, а також при всіх операціях із відпрацьованим ядерним паливом (ВЯП) як на $\mathrm{AEC}$, так і у сховищах ВЯП.
Для підтвердження консерватизму прийнятих припущень при проведенні аналізу з ядерної безпеки систем поводження з ВЯП необхідно обгрунтовано підтвердити виконання вимог нормативних документів [1-3] щодо забезпечення підкритичності в системі поводження з ВЯП за нормальних умов експлуатації, у разі порушення нормальних умов експлуатації та при проектних аваріях. У тому числі це стосується й задачі визначення максимальної похибки розрахунку ефективного коефіцієнта розмноження нейтронів $k_{\text {еф }}$ в обраних для аналізу ядерної безпеки розрахункових кодах.

Розрахунки критичності $€$ невід'ємною частиною аналізу з ядерної та радіаційної безпеки. Згідно

(c) В. І. Борисенко, В. В. Горанчук, Ю. Ф. Піонтковський, І. О. Тітімець, 2019 
з вимогами нормативних документів [1-3] у матеріалах, що містять елементи, які здатні до поділу, під час транспортування та зберігання не повинно виникнути самопідтримувальної ланцюгової реакції, тому 3 урахуванням запасу ефективний коефіцієнт розмноження нейтронів має не перевищувати значення $k_{\text {eф }}<0,95$. Така ситуація може виникнути, наприклад, при транспортуванні, зберіганні свіжого ядерного палива у вузлах зберігання свіжого палива, ВЯП у басейні витримки чи сховищі ВЯП. Згідно з аналізом критичності розробляються системи зберігання та транспортування, що не допускають виникнення самопідтримувальної ланцюгової реакції поділу навіть у найсприятливіших для цього умовах.

Для розрахунку критичності у наш час використовують спеціалізовані розрахункові коди, яких на сьогодні чимало. Тому постає питання обгрунтованого вибору. У цій роботі буде порівняно два розрахункових коди MCNP та SCALE.

\section{Опис експерименту}

Для верифікації розрахункових кодів було використано дані експериментів, проведених у національному науковому центрі «Курчатовський інститут» на установці SF-9, що експлуатувалась у 1966-1987 рр. Серія досліджень нейтронно-фізичних параметрів водо-уранових решітчастих структур типу ВВЕР була проведена в 1973 р. Суть експериментів полягала у визначенні висоти сповільнювача як функції числа паливних стрижнів - твелів. Паливний стовп мав довжину 1250 мм, а стрижні розташовувались у трикутній решітці з кроком 12,7 мм, що відповідає кроку розташування твелів у тепловидільній збірці (ТВ3) ВВЕР-1000. Збагачення за ${ }^{235} \mathrm{U}$ становило 3,5 \% мас. Усього в серії критичних експериментів було досліджено 12 різних конфігурацій. Паливні стрижні розміщуються всередині циліндричного резервуара, виготовленого 3 нержавіючої сталі (12Х18Н10T). Резервуар відкрито у верхній частині. Внутрішній діаметр ємності 2040 мм, висота 3700 мм, а товщина стінки 4 мм. Резервуар заповнюється водою до критичного рівня $\mathrm{H}_{\text {кр }}$ для забезпечення критичності обраного паливного завантаження. Паливні стрижні розміщені на нижній пластині опорної решітки та закріплені верхньою решіткою. Повна висота стрижнів 1356,5 мм. Паливо виготовляють з $\mathrm{UO}_{2}$ без центрального отвору. Діаметр паливної таблетки 7,65 мм. Оболонка виготовлена з цирконій-ніобієвого сплаву (внутрішній і зовнішній діаметри 7,7 та 9,1 мм відповідно). Верхня частина паливного стрижня містить пласт цирконій- ніобієвого сплаву (висота 7 мм, зовнішній і внутрішній діаметри 7,7 та 3 мм відповідно) і сталеву пружину. Діаметр нижнього та верхнього кінців тепловидільного елемента становить 6 мм. Висота сповільнювача під плитою опорної решітки 1600 мм. Схематично структуру установки SF-9 показано на рис. 1.

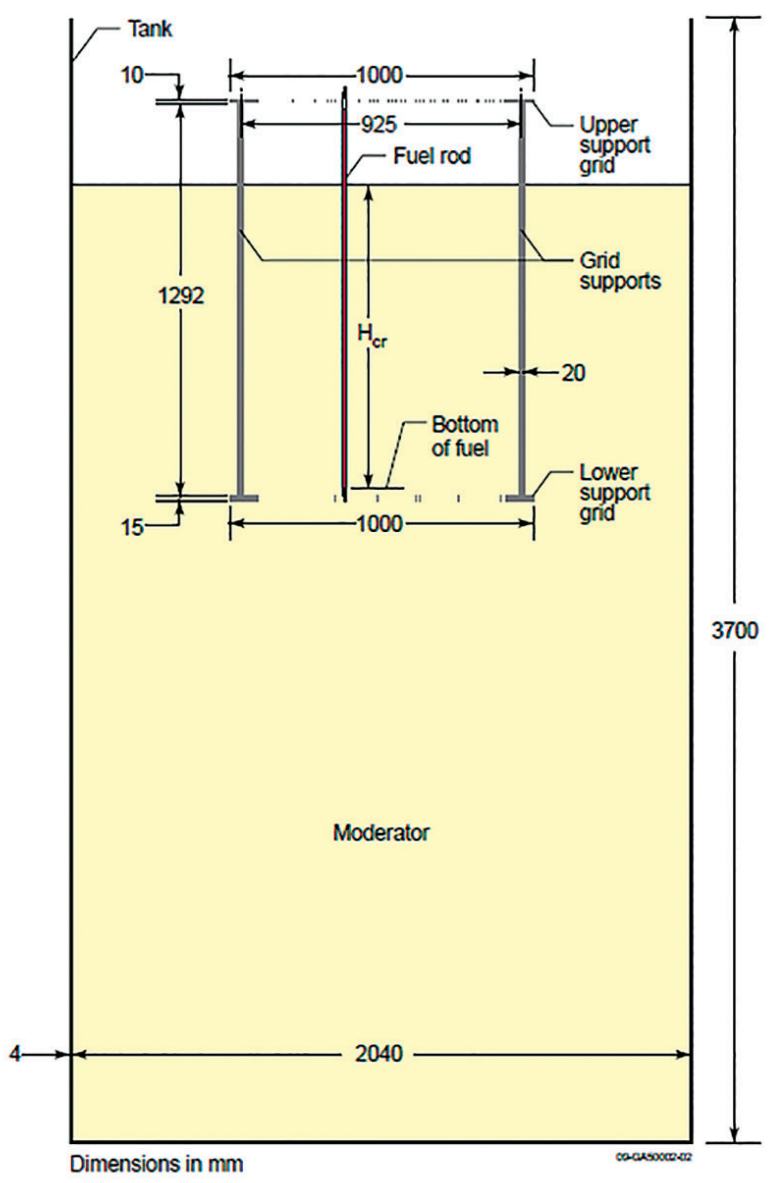

Рис. 1. Вертикальний розріз експериментальної установки SF-9

\section{Програмні коди}

Моделювання критичних бенчмарк-експериментів було виконано із застосуванням кодів MCNP4 [4] та SCALE-4 [5].

Програмний код SCALE використовується для проведення аналізу з ядерної безпеки і проектування паливовмісних систем. Код SCALE розроблено на замовлення Комісії з ядерного регулювання США в ОкРіджській національній лабораторії США в 1980 р. і широко використовується як у США, так і за його межами для виконання аналізів критичності, радіаційної безпеки, вигоряння тощо [6-8].

Програмний код SCALE застосовується для обгрунтування ядерної безпеки систем зберігання ВЯП 
у багатьох країнах, серед яких Болгарія, Німеччина, Угорщина, Словаччина, Швеція, США, Японія. Також SCALE застосовувався для обгрунтування ядерної безпеки сховищ відпрацьованого ядерного палива (СВЯП) ЗАЕС, СВЯП-2 ЧАЕС та централізованого СВЯП $[7,8]$.

Програмний код MCNP розроблено в Лос-Аламоській національній лабораторії США і застосовується для розрахунку задач із перенесення частинок (нейтронів, $\gamma$-квантів тощо). Код MCNP створено на основі методу Монте-Карло, що дає змогу проводити моделювання тривимірних систем будь-якої складності. MCNP широко застосовується для розрахунків критичності. При розрахунках MCNP використовувалася безперервна за енергією бібліотека нейтронно-фізичних констант, створена на основі ENDF/B-VII [7, 8].

\section{Опис створених моделей та результати}

Відповідно до опису в кодах MCPN та SCALE було створено по 12 моделей із різною кількістю паливних стрижнів і різною висотою сповільнювача $\mathrm{H}_{\text {кр }}$. Приклади таких моделей у кодах SCALE та MCNP наведено на рис. 2 i 3.

На рис. 2 і 3 прийняті такі позначення матеріалів: матеріал 1 - $\mathrm{UO}_{2}$ зі збагаченням по ${ }^{235} \mathrm{U} 3,5$ \% мас., матеріал 2 - цирконій-ніобієвий сплав, матеріал 3 сталь 12Х18Н10Т, матеріал 4 - вода.

Розрахункові значення $k_{\text {еф}}$, отримані в кодах SCALE і MCPN, а також експериментальні значення $k_{\text {eф }}$ для 12 критичних експериментів наведено у таблиці.

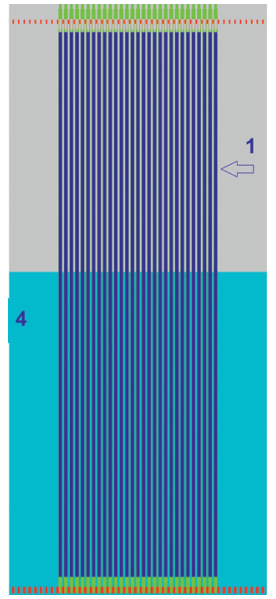

a

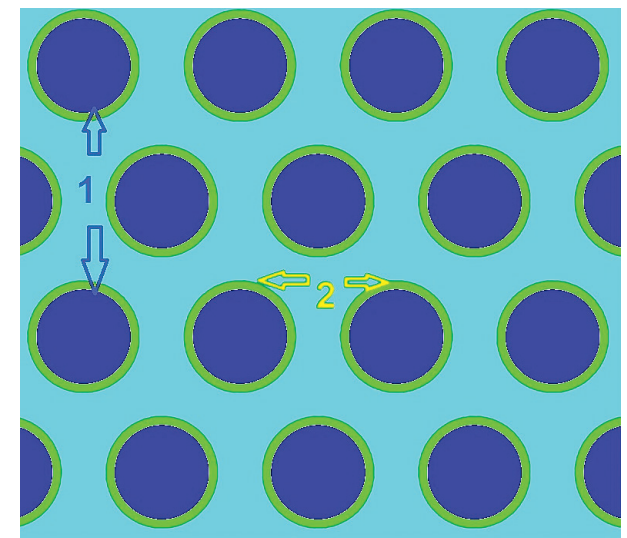

6

Рис. 2. Модель у коді SCALE: а - вертикальний розріз моделі (фрагмент); б - горизонтальний розріз моделі (фрагмент пучка твелів)

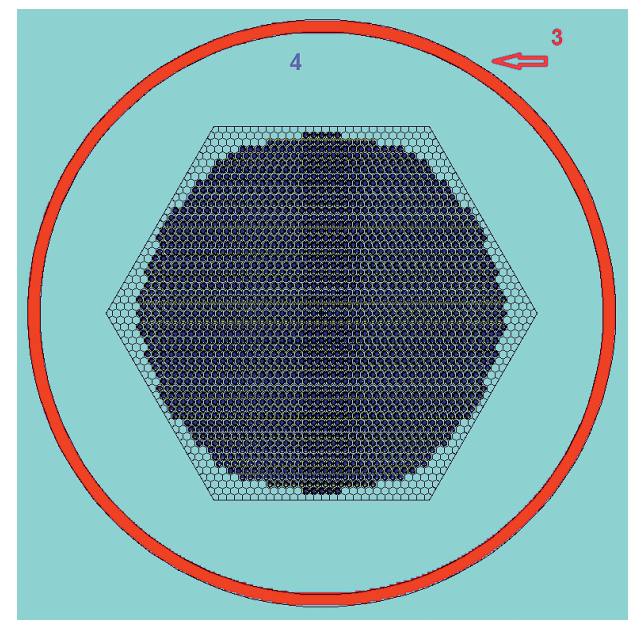

a

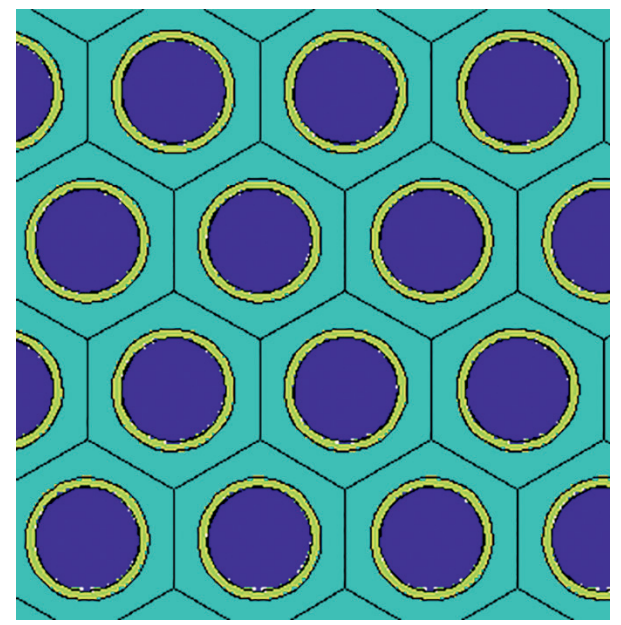

6

Рис. 3. Модель у коді MCNP: a - горизонтальний розріз моделі; 6 - фрагмент пучка твелів 


\section{Розрахункові значення $k_{\text {еф }}$ у кодах SCALE і MCNP та експериментальні значення $k_{\text {еф }}$ для 12 критичних експериментів}

\begin{tabular}{|c|c|c|c|c|c|c|c|}
\hline $\begin{array}{c}\text { № } \\
\text { конфігурації }\end{array}$ & $\begin{array}{c}\text { Кількість } \\
\text { твелів }\end{array}$ & $\mathrm{H}_{\text {кр }}, \mathrm{cm}$ & SCALE & СКВ, $\sigma_{\text {SCALE }}$ & МСNP & СКВ, $\sigma_{\text {мслр }}$ & Експеримент \\
\hline 1 & 1897 & 30,68 & 1,01000 & 0,00100 & 1,00115 & 0,00038 & 1,0024 \\
\hline 2 & 1495 & 35,31 & 1,01167 & 0,00087 & 1,00203 & 0,00039 & 1,0024 \\
\hline 3 & 1357 & 37,88 & 1,01350 & 0,00110 & 1,00127 & 0,00038 & 1,0024 \\
\hline 4 & 1141 & 43,81 & 1,01146 & 0,00097 & 1,00257 & 0,00038 & 1,0024 \\
\hline 5 & 931 & 55,15 & 1,00700 & 0,00120 & 1,00135 & 0,00046 & 1,0024 \\
\hline 6 & 823 & 67,23 & 1,00510 & 0,00100 & 1,00089 & 0,00039 & 1,0024 \\
\hline 7 & 793 & 72,52 & 1,00403 & 0,00093 & 1,00096 & 0,00034 & 1,0024 \\
\hline 8 & 769 & 78,03 & 1,00420 & 0,00080 & 1,00015 & 0,00033 & 1,0024 \\
\hline 9 & 745 & 85,66 & 1,00590 & 0,00110 & 1,00051 & 0,00035 & 1,0024 \\
\hline 10 & 727 & 94,00 & 1,00460 & 0,00100 & 1,00116 & 0,00031 & 1,0024 \\
\hline 11 & 709 & 104,6 & 1,00453 & 0,00098 & 1,00226 & 0,00044 & 1,0024 \\
\hline 12 & 691 & 117,89 & 1,00292 & 0,00090 & 1,00048 & 0,00031 & 1,0024 \\
\hline
\end{tabular}

Значення $\mathrm{H}_{\text {кр }}$ позначають висоту води, що відмірюється від нижнього рівня палива у твелі. Значення ефективного коефіцієнта розмноження нейтронів наведено у вигляді $k_{\text {eф }}=k_{\text {еф }}+1 \sigma(\sigma-$ середнє квадратичне відхилення, СКВ).

Проведено моделювання підкритичних станів при наближенні рівня води до критичного рівня для всіх 12 конфігурацій. На рис. 4 і 5 наведено залежності $k_{\text {еф }}$ від рівня води для конфігурацій № 5 i 11.

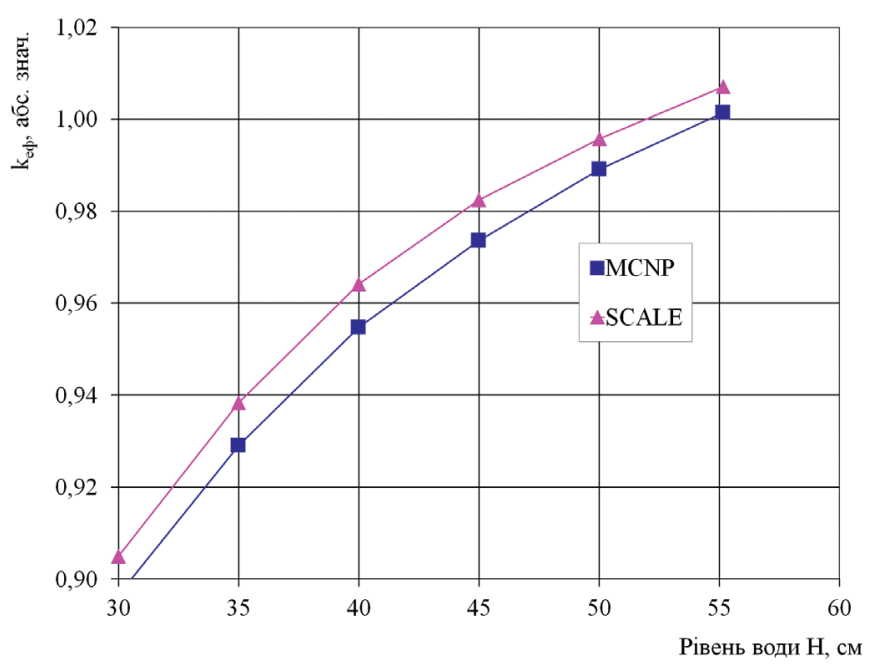

Рис. 4. Залежність $k_{\text {еф }}$ від рівня води для критичного експерименту № 5

\section{Висновки}

Результати проведеного аналізу з визначення похибки визначення $k_{\text {еф }}$ для критичних бенчмарк-експериментів у програмних кодах SCALE i MCNP дозволяють обгрунтовано підтвердити можливість їхнього використання для проведення аналізу з ядерної безпеки систем зберігання ядерного палива реакторів типу ВВЕР-1000. Максимальне значення СКВ визначення $k_{\text {еф }}$ становить для коду SCALE - 0,00120, а для коду MCNP - 0,00046.

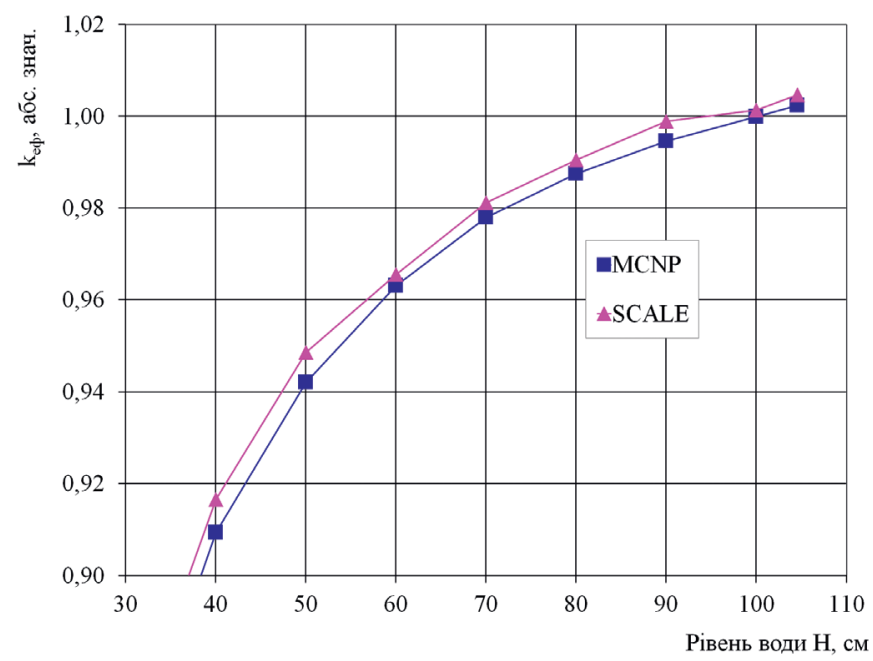

Рис. 5. Залежність $k_{\text {еф }}$ від рівня води для критичного експерименту № 11 


\section{Список використаної літератури}

1. Правила безопасности при хранении и транспортировании ядерного топлива на объектах ядерной энергетики, ПНАЭ Г-14-029-91. - Госпроматомнадзор СССР, 1991.

2. НП 306.2006.124-2006 (ПБПРМ-2006) Правила ядерної та радіаційної безпеки при перевезенні радіоактивних матеріалів / ГИЯРу. - 2006.

3. НП 306.2.105-2004. Основные положения обеспечения безопасности промежуточных хранилищ сухого типа / ГИЯРУ. - 2004.

4. MCNP - A General Monte Carlo N-Particle Transport Code, Version 4C, Manual / edited by J. F. Briesmeister. LA-13709-M. - 2000. - 790 p.

5. SCALE-4.4a: A Modular Code System for Performing Standardized Computer Analyses for Licensing Evaluation, NUREGCR-0200, Rev. 6 / Oak Ridge National Laboratory. - 1998.

6. Солдатов С. А. Определение систематической ошибки и дисперсии расчетной последовательности CSAS26 пакета программ SCALE-5 / C. А. Солдатов, С. В. Черницкий, С. Н. Леонов // Ядерна та радіаційна безпека. - 2011. - № 3 (51). - С. 47-52.

7. Борисенко В. И. Выбор консервативных допущений при обосновании ядерной безопасности систем хранения отработанного ядерного топлива / В. И. Борисенко, В. В. Горанчук, Ю. Ф. Пионтковский, Н. Н. Сапон // Ядерна та радіаційна безпека. - 2017. № 2 (74). - С. 48-53.

8. Борисенко В. І. Визначення консервативних припущень при обгрунтуванні ядерної безпеки систем зберігання ВТВ3 ВВЕР-440 / В. I. Борисенко, В. В. Горанчук, Ю. Ф. Піонтковський // Ядерна енергетика та довкілля. - 2017. - № 1 (9). - С. 13-17.

\section{В. И. Борисенко ${ }^{1,2}$, В. В. Горанчук ${ }^{1}$, Ю. Ф. Пионтковский ${ }^{2}$, И. А. Титимец ${ }^{2}$}

${ }^{1}$ Институт проблем безопасности АЭС НАН Украинь, ул. Льссогорская, 12, г. Киев, 03028, Украина

${ }^{2}$ Киевский национальньй университет имени Тараса

Шевченко, просп. акад. Глушкова, 4, г. Киев, 03022, Украина

Результаты валидации расчетных кодов SCALE и MCNP на данных критических бенчмарк-экспериментов на установке SF-9

Представлены результаты применения расчетных кодов SCALE и MCNP для моделирования критических бенчмарк-экспериментов на установке SF-9. Установка SF-9 создана для проведения исследований условий достижения критичности в зависимости от числа твэлов (типа
ВВЭР-1000) и уровня воды в баке установки. Проведение таких расчетных исследований является обязательным при обосновании возможности применения расчетных кодов, выбранных для анализа ядерной безопасности технологических операций по перемещению, транспортировке и хранению как свежего ядерного топлива (в узлах хранения свежего топлива на энергоблоках АЭС), так и отработанного ядерного топлива (контейнеры перегрузки, хранилища отработанного ядерного топлива) реакторов различных типов. Например, при обосновании ядерной безопасности систем хранения отработанного ядерного топлива необходимо подтвердить, что максимальное значение эффективного коэффициента размножения нейтронов $k_{\text {еф }}$ ниже установленного нормативного предела 0,95 для условий нормальной эксплуатации, при нарушениях нормальной эксплуатации и при проектных авариях.

Представлены результаты расчетов $k_{\text {eф }}$ для 12 критических экспериментов на установке SF-9, которые позволяют сделать выводы относительно погрешности определения $k_{\text {еф }}$ в кодах SCALE и MCNP, а также обоснованно, по результатам валидации, выбрать расчетные коды для проведения анализа ядерной безопасности систем хранения ядерного топлива, в том числе и отработанного ядерного топлива.

Ключевые слова: ядерная безопасность, критический эксперимент, твэл, отработанное ядерное топливо, эффективный коэффициент размножения.

\section{I. Borysenko ${ }^{1,2}$, V. V. Goranchuk ${ }^{1}$, Yu. F. Piontkovskyi ${ }^{2}$ I. O. Titimets ${ }^{2}$}

${ }^{1}$ Institute for Safety Problems of Nuclear Power Plants, NAS

of Ukraine, Lysogirska str., 12, Kyiv, 03028, Ukraine

${ }^{2}$ Nuclear Physics Department, Taras Shevchenko National University, Prospect Glushkova, 4, building 1, Kyiv, 03022, Ukraine

\section{Validation Results of Scale and MCNP Calculation Codes on Data of Benchmark Critical Experiments at SF-9 Installation}

The article presents the results of calculations of benchmark critical experiments in the codes SCALE and MCNP. Experiments were performed on SF-9 installation, which was operated by Russian Research Centre "Kurchatov Institute" in 1966-1987. The SF-9 is designed to conduct criticality studies, depending on the number of fuel rods (type VVER-1000) and the level of coolant (water) in the installation tank. Such research is obligatory when substantiating the possibility of using 
the calculation codes selected for the analysis of nuclear safety of technological operations on the transfer, transportation and storage of fresh nuclear fuel (the storage site of nuclear fuel on the power unit), as well as spent nuclear fuel (transfer casks, repositories of spent nuclear fuel) reactors of various types. For example, when substantiating the nuclear safety of spent fuel storage systems, it must be confirmed that the maximum value of the effective neutron multiplication factor $k_{\text {ef }}$ is lower than the established normative limit of 0.95 for normal operation conditions, in case of violations of normal operation and in case of design accident.

A series of 12 experiments on the SF-9 installation investigating the neutron-physics parameters of VVER-type uranium-water lattices was carried out in 1973. Near-cylindrical cores with a regular hexagonal lattice at a pitch of 12.7 $\mathrm{mm}$ and $3.5 \mathrm{wt} . \%{ }^{235} \mathrm{U}$ fuel enrichment were build. Criticality was reached by varying the moderator height. The number of fuel rods varied from 691 to 1897 and the critical moderator height varied from $30.68 \mathrm{~cm}$ to $117.89 \mathrm{~cm}$ above the bottom surface of the fissile column.

The article presents the results of calculations of $k_{\text {ef }}$ for these 12 critical experiments, which allow us to draw conclusions regarding the error of the value determination of $k_{\text {ef }}$ of SCALE and MCNP codes, and to select a calculation code for the analysis of nuclear safety of nuclear fuel storage systems, including spent nuclear fuel, on the base of validation results.

Keywords: nuclear safety, critical experiments, fuel rod, spent nuclear fuel, effective neutron multiplication factor.

\section{References}

1. PNAE G-14-029-91. Safety Regulations for the Storage and Transportation of Nuclear Fuel at Nuclear Power Sites. Gospromatomnadzor of USSR, 1991. (in Russ.)

2. NP 306.6.124-2006 (PBPRM-2006). Nuclear and Radiation Safety Regulations for Shipment of Radioactive Materials. State Nuclear Regulatory Inspectorate of Ukraine, 2006. (in Ukr.)

3. NP 306.2.105-2004. Basic Provisions on Safety Ensuring of Interim Storage Facilities of Dry Type. State Nuclear Regulatory Inspectorate of Ukraine, 2004. (in Ukr.)

4. Briesmeister J. F. (ed.) (2000). MCNP - A General Monte Carlo $N$-Particle Transport Code, Version 4C. LA-13709-M, 790 p.

5. SCALE-4.4a: A Modular Code System for Performing Standardized Computer Analyses for Licensing Evaluation / NUREG-CR-0200, Rev.6. Oak Ridge National Laboratory, September, 1998.

6. Soldatov S. A., Chernitskiy S. V., Leonov S. N. (2011). Determination of Systematic Error and Dispersion of Estimated Sequence CSAS26 of the SCALE-5 Software Package for Hexagonal Geometry. Yaderna ta radiatsiina bezpeka [Nuclear and Radiation Safety], vol. 51, no. 3, pp. 47-52. (in Russ.)

7. Borysenko V. I., Goranchuk V. V., Piontkovskyi Yu. F., Sapon M. M. (2017). Selection of Conservative Assumptions in Nuclear Safety Justification of SNF Storage Systems. Yaderna ta radiatsiina bezpeka [Nuclear and Radiation Safety], vol. 74, no. 2, pp. 48-53. (in Russ.)

8. Borysenko V. I., Goranchuk V. V., Piontkovskyi Yu. F. (2017). Choice of conservative assumptions in justification of nuclear safety of VVER 440 SFA storage systems. Yaderna enerhetyka ta dovkillia [Nuclear Power and the Environment], vol. 9, no. 1, pp. 13-17. (in Ukr.) 


\section{Т. І. Матченко, Т. Ю. Верюжська, Н. О. Сирота, Л. Б. Шаміс}

AT «Київський науково-дослідний та проектно-конструкторський інститут «Енергопроект», просп. Перемоги, 4, м. Київ, 01135, Україна

\section{Аналіз міцності захисної оболонки реактора протягом зміни температури та тиску, спричинених аварією}

Ключові слова:

захисна оболонка,

герметичне огородження, локалізуючі системи безпеки, максимальна проектна аварія, арматурний канат.

\begin{abstract}
Розроблено розрахункову модель реакторного відділення в цілому та його захисну оболонку з використанням оболонкових скінченних елементів на базі розрахункового комплексу SCAD, що дає змогу задавати будь-які зусилля в будь-якому з 36 арматурних канатів купола і в будь-якому з 96 арматурних канатів циліндра захисної оболонки. Розраховано зусилля в арматурних канатах, які забезпечують міцність і герметичність залізобетонних конструкцій захисної оболонки при максимальній проектній аварії для усіх комбінацій температур і надлишкових тисків протягом 10 год аварії.
\end{abstract}

\section{Вступ}

Для виконання функцій локалізуючих систем безпеки (ЛСБ) та систем герметичного огородження (СГО) реакторних відділень атомних електростанцій (АЕС) з реакторами ВВЕР-1000 застосовують захисну оболонку (3О), завдання якої полягає в недопущенні виходу радіоактивних речовин з реакторного відділення в зовнішній простір у випадку аварії реактора чи паропроводів (рис. 1).

Захисна оболонка складається з залізобетонних огороджувальних конструкцій (ЗОК), які забезпечують міцність і за можливості герметичність на випадок максимальної проектної аварії (МПА) і внутрішнього сталевого облицювання ЛСБ, яке забезпечує герметичність у випадку МПА. 30 з опорною плитою на позначці 13,2 м є основним елементом СГО. Вона запроектована 3 попередньо напруженого залізобетону у вигляді циліндра з внутрішнім діаметром $45 \mathrm{M}$ i висотою 53,35 м, покритого пологим сферичним куполом. Циліндрична частина споруди на позначці 13,2 м спирається на залізобетонну плиту перекриття (опорну плиту оболонки). Попереднє напруження ЗОК забезпечується зусиллями натягнення 96 арматурних канатів (АК) у циліндричній частині 30 і 36 АК у купольній частині.

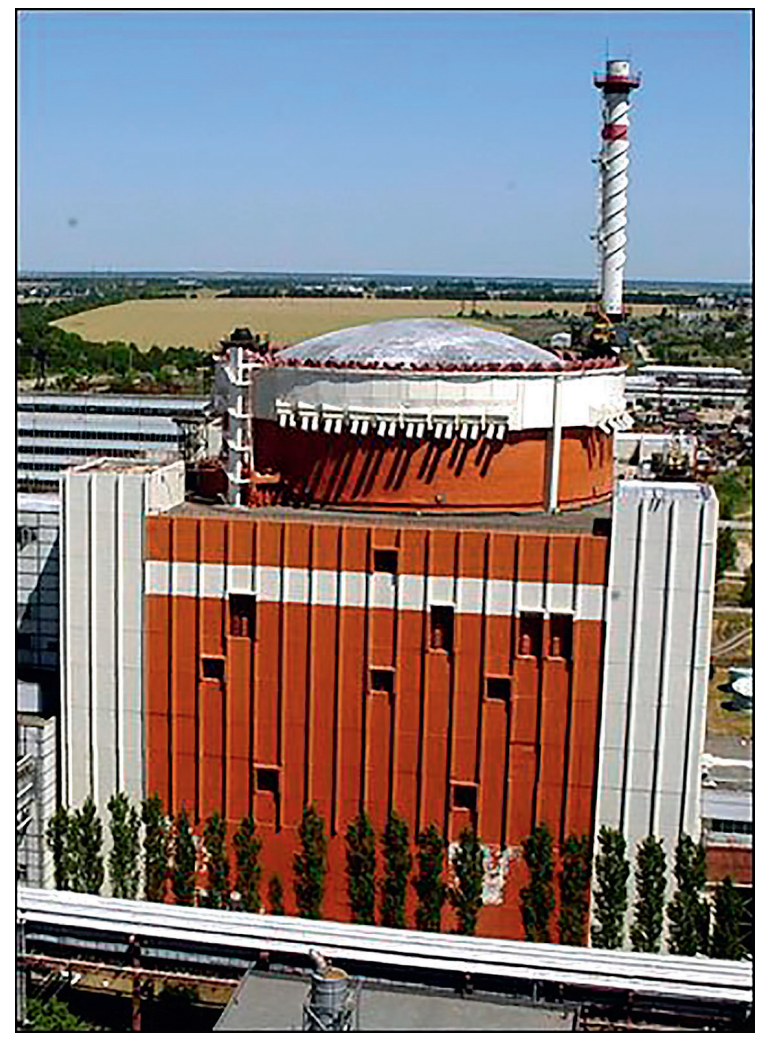

Рис. 1. Загальний вигляд реакторного відділення BВEР-1000 Южно-Української АЕС із 30

() Т. І. Матченко, Т. Ю. Верюжська, Н. О. Сирота, Л. Б. Шаміс, 2019 
У випадку МПА відбувається збільшення температури і тиску в реакторному відділенні. Цей процес триває 10 год, і 30 повинна забезпечувати міцність і герметичність протягом усього періоду дії МПА для всіх реальних комбінацій тиску і температури.

Проблема полягає в тому, що в разі натягнення AK із зусиллям, яке створює напруження у дротах, що перевищує межу пропорційності сталі, відбувається релаксація напружень (втрата зусиль у канатах) протягом експлуатації, що створює необхідність періодичного підтягування канатів до проектних значень зусиль. У процесі підтягування відбувається збільшення довжини дротів канату, що зменшує їхній деформаційний ресурс. Коли деформаційний ресурс буде вичерпаний унаслідок декількох підтягувань АК, канат може розірватися, навіть якщо напруження у дротах не перевищили межу текучості сталі.

У випадку розриву АК може відбутися руйнування каналу і його забивання уламками. Це в свою чергу ускладнює заміну зруйнованого канату новим. У разі розриву декількох канатів, може створитися ситуація, коли інші канати з будь-якими зусиллями натягнення не зможуть забезпечити міцність та герметичність 30 у випадку МПА.

Таким чином, актуальним $є$ завдання розрахувати такі мінімальні зусилля в АК куполу і циліндричної частини 30 реального реакторного відділення, що знаходиться в експлуатації, які забезпечать міцність і герметичність 30 для всіх комбінацій температури і тиску протягом дії МПА з урахуванням накопичених пошкоджень у ЗОК і АК та сталевому облицюванні.

\section{Навантаження протягом МПА}

У разі МПА через 15 с після іï̈ початку температура середовища (повітря) підвищується до $150{ }^{\circ} \mathrm{C}$, надлишковий тиск при цьому досягає 0,4 МПа. Після включення спринклерних систем параметри середовища (температура, тиск) змінюються залежно від часу проходження МПА. Час існування аварії приймається рівним 10 год. Розрахунок розподілення температур у стінках $30 К 30$ в різні моменти проходження МПА був виконаний для умов нестаціонарної теплопровідності. Розподілення температур за товщиною стінки циліндричної частини ЗОК [1] наведено в табл. 1 і 2 за умови, що на зовнішній поверхні ЗОК температура становить $-5{ }^{\circ} \mathrm{C}$. Для часу 15 с або 0,004 год після початку аварії розподілення температур показано на рис. 2.
Таблиця 1. Значення температури для різного часу проходження МПА протягом перших 5 год після МПА, ${ }^{\circ} \mathrm{C}$

\begin{tabular}{|c|c|c|c|c|c|c|}
\hline Показник & $\begin{array}{c}\text { чере3 } \\
\text { 0,004 год }\end{array}$ & $\begin{array}{c}\text { чере3 } \\
1 \text { год }\end{array}$ & $\begin{array}{c}\text { чере3 } \\
\text { 2 год }\end{array}$ & $\begin{array}{c}\text { через } \\
\text { 3 год }\end{array}$ & $\begin{array}{c}\text { чере3 } \\
\text { 4 год }\end{array}$ & $\begin{array}{c}\text { чере3 } \\
\text { год }\end{array}$ \\
\hline $\begin{array}{c}t_{6}- \\
\text { внутрішня } \\
\text { поверхня }\end{array}$ & 39,8 & 58 & 67 & 73 & 75 & 76,4 \\
\hline$t_{1}$ & 36,1 & 41,7 & 46,9 & 50,8 & 54,2 & 57,2 \\
\hline$t_{2}$ & 32,3 & 33,9 & 35,8 & 36,9 & 37,8 & 38,7 \\
\hline$t_{3}$ & 28,6 & 29,2 & 30,2 & 30,5 & 30,8 & 31,2 \\
\hline$t_{4}$ & 24,9 & 25,2 & 26,0 & 26,1 & 26,2 & 26,4 \\
\hline$t_{5}$ & 21,1 & 21,4 & 22,1 & 22,2 & 22,3 & 22,5 \\
\hline$t_{6}$ & 17,4 & 17,6 & 18,3 & 18,4 & 18,5 & 18,7 \\
\hline$t_{7}$ & 13,7 & 13,7 & 13,7 & 13,7 & 13,7 & 13,7 \\
\hline$t_{8}$ & 9,9 & 9,9 & 9,9 & 9,9 & 9,9 & 9,9 \\
\hline$t_{9}$ & 6,2 & 6,2 & 6,2 & 6,2 & 6,2 & 6,2 \\
\hline$t_{10}$ & 2,5 & 2,5 & 2,5 & 2,5 & 2,5 & 2,5 \\
\hline$t_{11}$ & $-1,3$ & $-1,3$ & $-1,3$ & $-1,3$ & $-1,3$ & $-1,3$ \\
\hline $\begin{array}{c}t_{\text {н }}-\text { зовнішня } \\
\text { поверхня }\end{array}$ & $-5,0$ & $-5,0$ & $-5,0$ & $-5,0$ & $-5,0$ & $-5,0$ \\
\hline $\begin{array}{c}\text { Тиск середо- } \\
\text { вища, атм }\end{array}$ & 5,0 & 4,5 & 4,0 & 3,5 & 3,0 & 2,5 \\
\hline
\end{tabular}

Таблиця 2. Значення температури для різного часу проходження МПА протягом 5-10 год після МПА, ${ }^{\circ} \mathrm{C}$

\begin{tabular}{|c|c|c|c|c|c|}
\hline Показник & $\begin{array}{c}\text { через } \\
6 \text { год }\end{array}$ & $\begin{array}{c}\text { чере3 } \\
7 \text { год }\end{array}$ & $\begin{array}{c}\text { чере3 } \\
8 \text { год }\end{array}$ & $\begin{array}{c}\text { чере3 } \\
9 \text { год }\end{array}$ & $\begin{array}{c}\text { чере3 } \\
10 \text { год }\end{array}$ \\
\hline$t_{6}$ & 78 & 76 & 74 & 70 & 65 \\
\hline$t_{1}$ & 60,3 & 52,1 & 63,2 & 63,5 & 63,3 \\
\hline$t_{2}$ & 39,8 & 40,2 & 40,6 & 40,6 & 40,6 \\
\hline$t_{3}$ & 31,9 & 32,0 & 32,2 & 32,2 & 32,2 \\
\hline$t_{4}$ & 26,9 & 26,9 & 27,0 & 27,0 & 27,0 \\
\hline$t_{5}$ & 23,0 & 23,0 & 23,1 & 23,1 & 23,1 \\
\hline$t_{6}$ & 19,2 & 19,2 & 19,3 & 19,3 & 19,3 \\
\hline$t_{7}$ & 15,6 & 15,6 & 15,6 & 15,6 & 15,6 \\
\hline$t_{8}$ & 9,9 & 9,9 & 9,9 & 9,9 & 9,9 \\
\hline$t_{9}$ & 6,2 & 6,2 & 6,2 & 6,2 & 6,2 \\
\hline$t_{10}$ & 2,5 & 2,5 & 2,5 & 2,5 & 2,5 \\
\hline$t_{11}$ & $-1,3$ & $-1,3$ & $-1,3$ & $-1,3$ & $-1,3$ \\
\hline$t_{н}$ & $-5,0$ & $-5,0$ & $-5,0$ & $-5,0$ & $-5,0$ \\
\hline $\begin{array}{c}\text { Тиск середо- } \\
\text { вища, атм }\end{array}$ & 2,1 & 1,68 & 1,45 & 1,30 & 1,20 \\
\hline
\end{tabular}

\section{Моделювання 30 методом скінченних елементів}

Розрахункова схема (модель 1) складається 3 об'ємних скінченних елементів (СЕ), що моделюють роботу залізобетонних конструкцій 3О. При моде- 


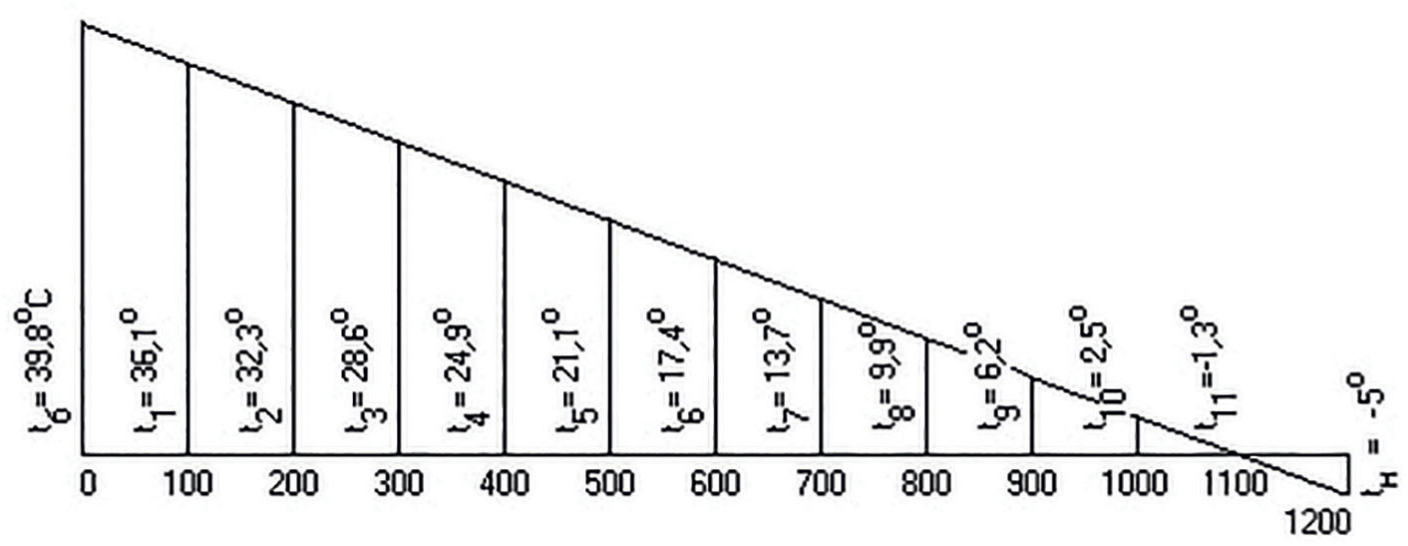

Рис. 2. Розподілення температури за товщиною в стінці циліндричної частини 3ОК (розмір за товщиною у мм) через 15 с після МПА

люванні стінка циліндра та купол поділяються на 4 основні шари бетону за товщиною без урахування сталевого облицювання, яке моделюється плоскими СЕ оболонки товщиною 8 мм.

Розрахункову модель, яка використовує об'ємні, оболонкові та стержньові елементи й дозволяє відобразити реальну геометрію та фізичні характеристики конструктивних елементів 30, показано на рис. 3.

Розрахунок напружено-деформованого стану (НДС) виконано для умов дії на споруду навантажень: власної ваги конструкцій споруди; зусиль обтискання споруди АК системи переднапруги та зусилля в анкеpax AK; аварійного тиску пароповітряної суміші від
0,2 до 0,4 МПа; температури на внутрішній поверхні оболонки, що змінюється в межах від +40 до +78 $\mathrm{C}, \mathrm{i}$ на зовнішній поверхні оболонки розрахункової температури $-5{ }^{\circ} \mathrm{C}$.

Арматурні канати моделюються стержневими елементами (рис. 4).

Канати циліндричної частини розташовані в три шари і огинають оболонку за спіральною траєкторі$є ю(а)$. Канати купольної частини розташовані в двох паралельних шарах із взаємною орієнтацією, близькою до ортогональної (б). АК мають спільні вузли тільки з шаром бетону, на який передаються зусилля обтиску.
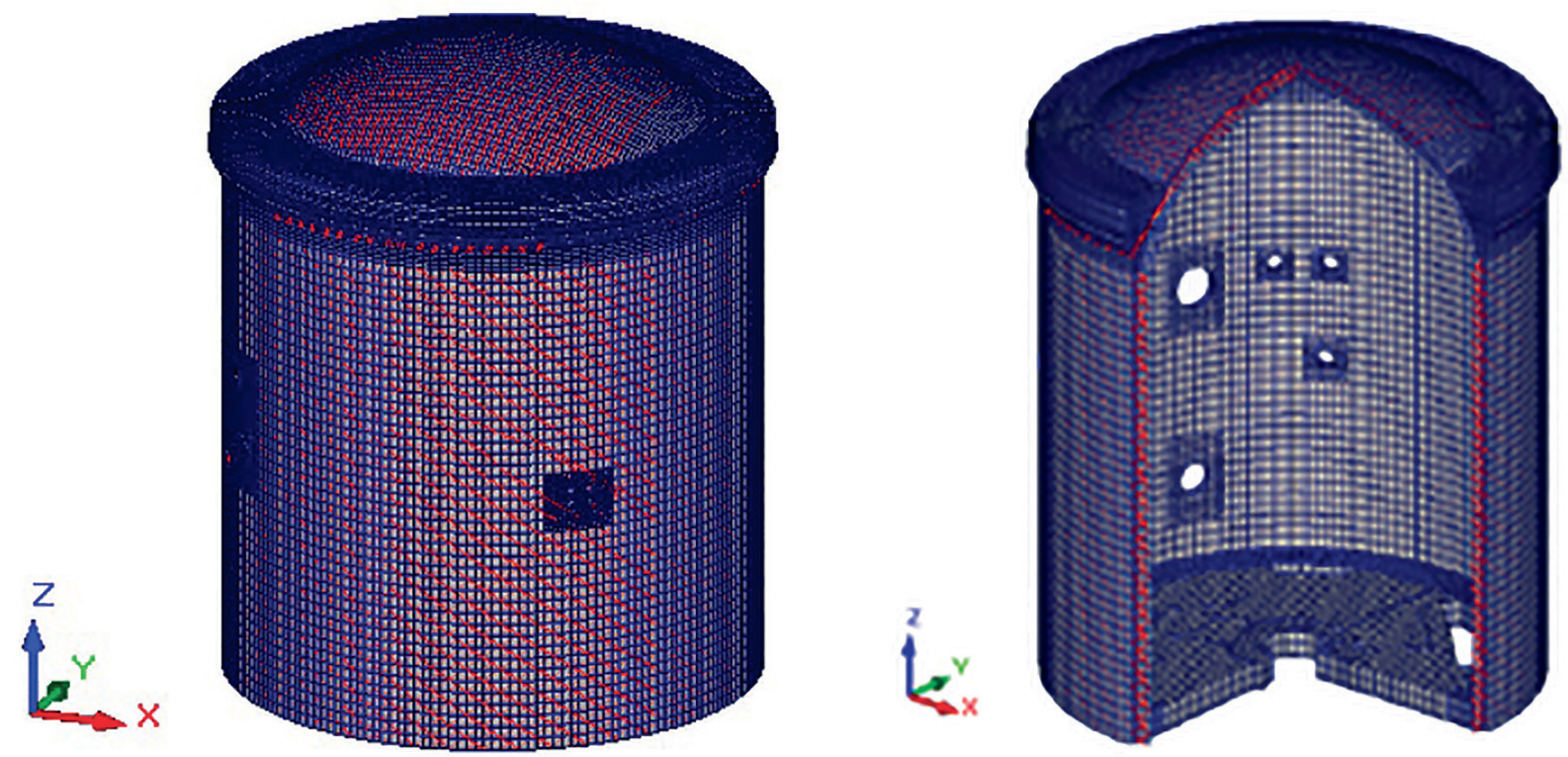

Рис. 3. Розрахункова модель 30 реакторного відділення та ЛСБ СГО (модель 1) 


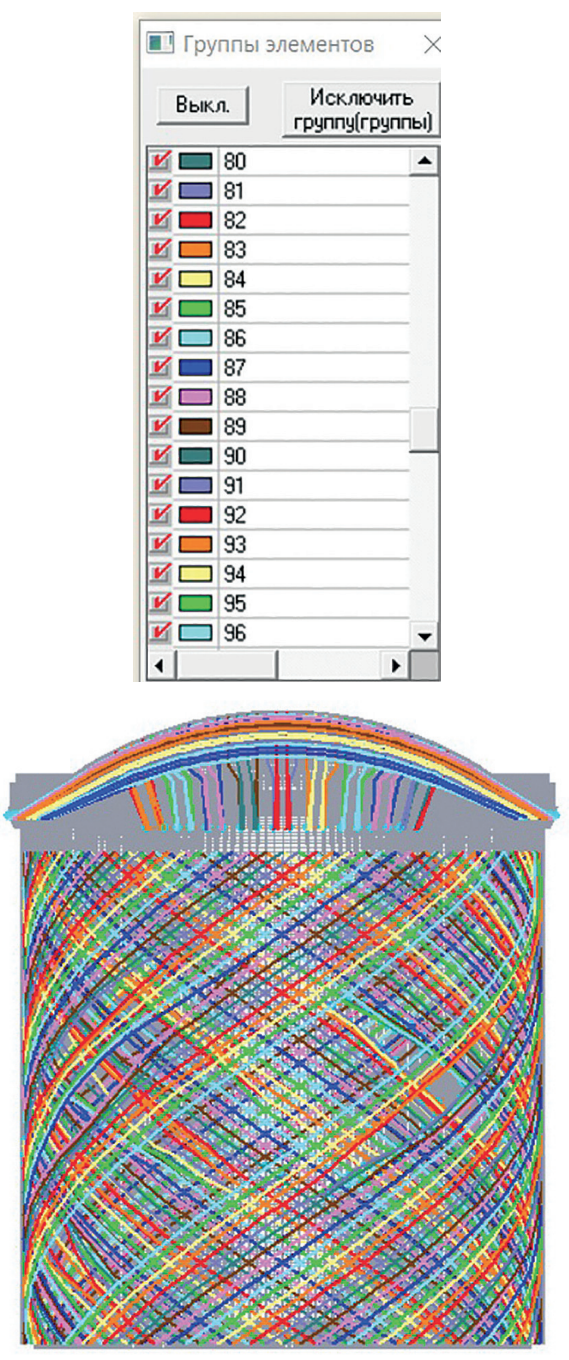

a
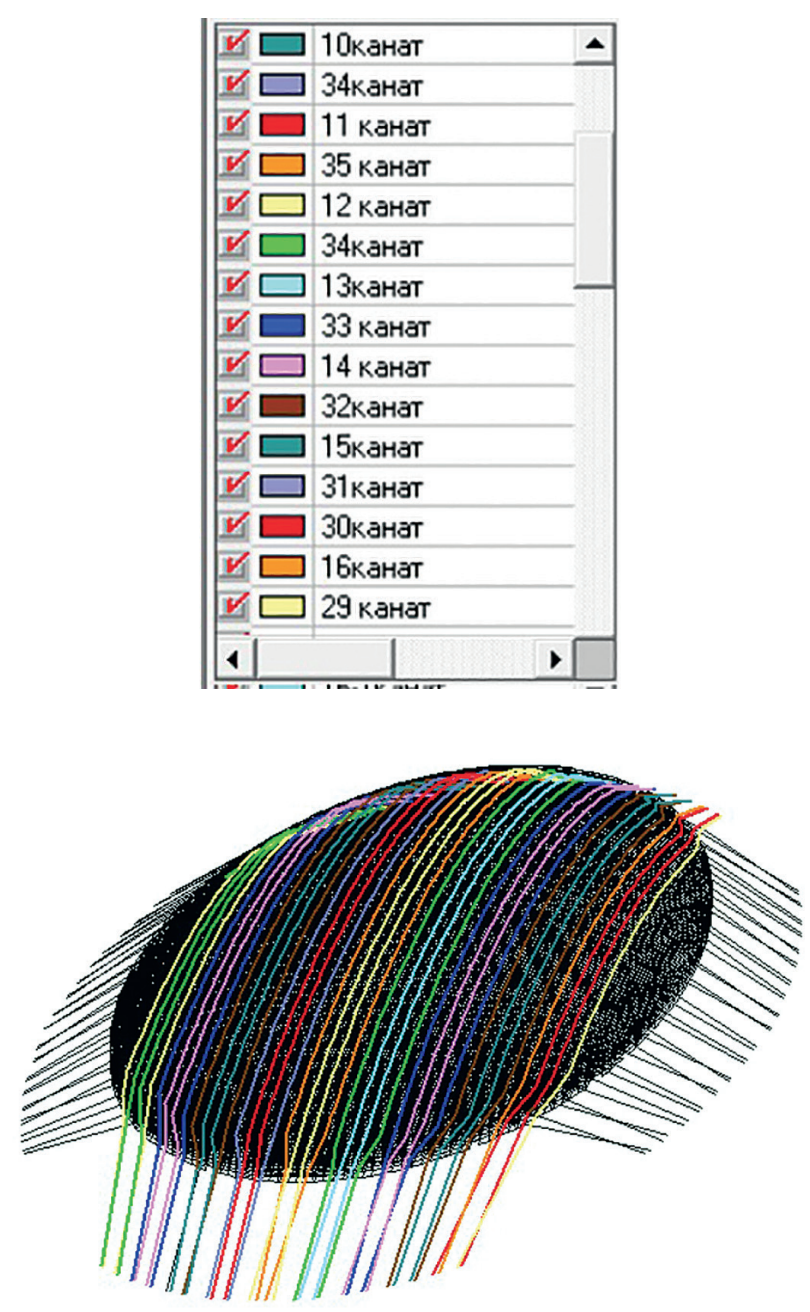

6

Рис. 4. Розрахункова модель 30 реакторного відділення (модель 1).

Різні відтінки зображення груп елементів, які відповідають номеру каната: а - моделювання АК циліндричної частини $3 \mathrm{O}$ стержневими СЕ; 6 - моделювання АК купола 3 О стержневими СЕ

Процедура завдання навантаження на 30 від власної ваги конструкцій споруди прийнята стандартною для методу CE і тому тут не деталізується.

Моделювання силової дії на 30 від обтискання АК системою попереднього напруження захисної оболонки здійснювалося за методикою, що враховує реальні траєкторії проходження канатів системи переднапруги (див. рис. 4 , а).

Значення зусилля натягнення АК у заданій точці його траєкторії визначається з урахуванням втрат зусилля по довжині АК через тертя між АК і поверхнею каналу.

Функція зміни зусилля натягнення АК по його довжині прийнята відповідно до залежності, наведеної в п. 3.3.5.6 ДСТУ Б В.2.6-156:2010.

$$
\begin{gathered}
\Delta P_{\mu}(x)=P_{\max }\left(1-\frac{1}{e^{\mu(\theta+k x)}}\right)=P 2-P 1 \\
\Delta P=P_{\text {netto }}\left(e^{-\left(\omega x_{1}+0,089 \theta_{1}\right)}-e^{-\left(\omega x_{2}+0,089 \theta_{2}\right)}\right)
\end{gathered}
$$

де $x_{1}$ i $x_{2}$ - місцева координата вузла вздовж осі АК в межах одного СЕ початку і кінця АК; $\theta$ - кут відхилення АК від своєї осі на ділянці, що розглядається між вузлами одного АК вздовж траєкторії АК, рад; $P_{1}$ і $P_{2}-$ зусилля в АК на виході і на вході у вузлах загальних - зі скінченими елементами оболонки в напрямку траєкторії АК; $e$ - основа натурального логарифму; $\mu$ - узагальнений коефіцієнт тертя між АК і поверхнею канала; $k$ - випадкове 
кутове переміщення від точки для внутрішньої арматури $(0,005<k<0,01)$.

У моделі із застосуванням оболонкових СЕ обтиснення оболонки АК і втрати на тертя канатів по бетону каналів моделюється набором сил, докладених у вузлах оболонкових СЕ по траєктоpiï AK.

У випадку проковзування АК відбувається розвантаження на ділянці ковзання. У такому випадку сили, що моделюють втрати на тертя, приймаються рівними нулю, і залишаються тільки сили, що моделюють обтиснення бетону.

Сила тиску АК на стінку канала в межах одного CE між точками 1 і 2 (вузлами СК) за правилами паралелограму визначається за формулою

$$
\Delta Q=\sqrt{P_{1}^{2}+P_{2}^{2}-2 \cdot P_{1} \cdot P_{2} \cdot \cos \left[\pi-\left(\theta_{1}-\theta_{2}\right)\right]},
$$

або за формулою

$$
\Delta Q=N_{0}\left(1-e^{-\delta \theta_{2}}+1-e^{-\delta \theta_{1}}\right) \cdot \sin \left(\theta_{2}-\theta_{1}\right)=\left(N_{2}+N_{1}\right) \cdot \sin \left(Q_{2}-Q_{1}\right) .
$$

Отже, для кожного АК розрахункової моделі згідно з траєкторією його проходження було обчислено значення зусилля обтискання в спільних вузлах АК та об'ємного СЕ розрахункової моделі. Навантаження було визначено як вузлове в глобальній системі координат.

Моделювання розташування АК в різних шарах на циліндричну 30 показано на рис. 5 .

Якщо одним з навантажень $\epsilon$ перепад температур за товщиною оболонки, тоді доцільно моделювання 30 і реакторного відділення в цілому виконувати оболонковими СЕ.

У випадку застосування оболонкових СЕ для моделювання конструкції 30 і реакторного відділення в цілому розрахунковий комплекс (РК) SCAD дозволяє визначити НДС для статичних $\mathrm{i}$ температурних впливів в одній комбінації, виходячи з умови забезпечення міцності, виникнення або обмеження розкриття тріщин визначеною величиною. Програма АРБАТ, яка входить до комплексу PK SCAD, дозволяє виконати перевірку на міцність і виявити розкриття тріщин перерізів залізобетонних конструкцій з урахуванням реальних діаметрів арматурних стрижнів, їхнього кроку, класу арматури і бетону.

Таким чином, виникла необхідність побудови розрахункової моделі 30 (модель 2) з використанням оболонкових елементів замість об'ємних. Навантаження обтиснення АК, які визначалися для моделі 1 , переносяться на оболонкову модель 2 шарами разом з АК за допомогою режиму складання, який передбачений в РК SCAD.

Моделювання передання зусиль від АК на циліндричну оболонку показано на рис. 6.

Моделювання зусиль від АК у розрахунковій моделі купольної частини 30 показано на рис. 7.

Загальний вигляд розрахункової моделі 30 реакторного відділення наведено на рис. 8.

Жорсткість основи у вертикальному напрямку під фундаментною плитою моделювалась двома параметричними коефіцієнтами жорсткості С1 і C2 3 урахуванням інженерно-геологічних характеристик грунту під фундаментом, зокрема реакторного відділення № 4 Запорізької АЕС. У горизонтальних напрямках за осями X і Y жорсткість основи моделювалася СЕ типу 56 (зв'язки кінцевої жорсткості), які прикладені до кожного вузла фундаментної плити.
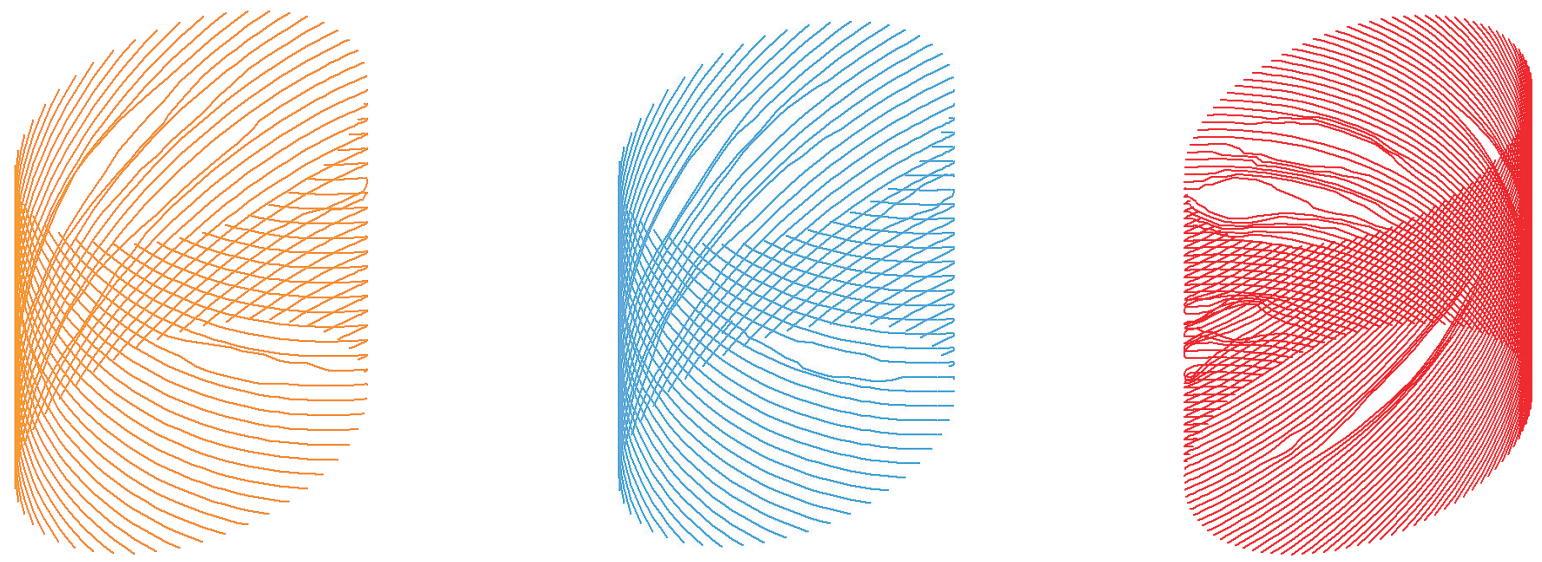

Рис. 5. Моделювання АК циліндричної частини 30 представлено за шарами їх розташування 


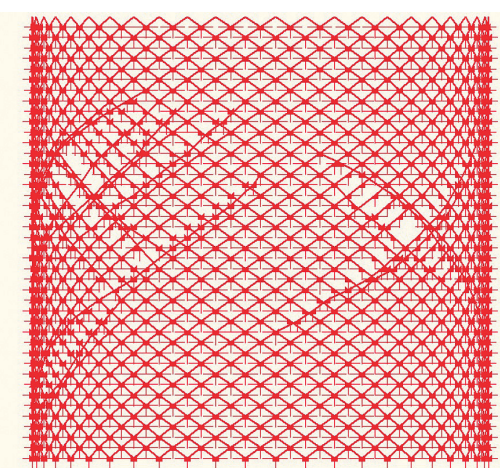

Зовнішній шар

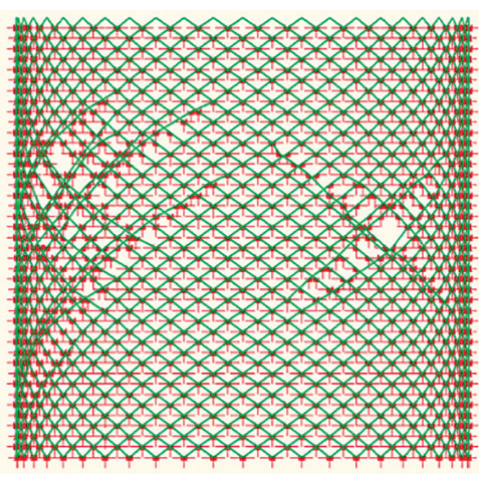

Внутрішній шар

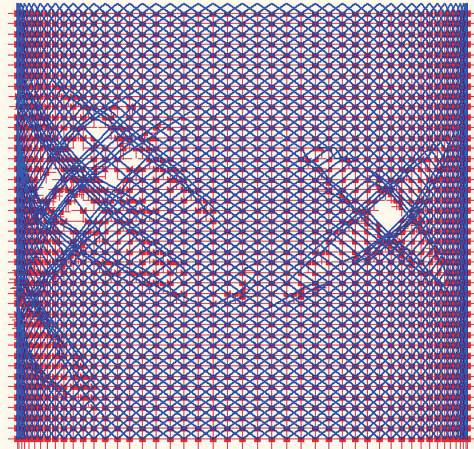

Середній шар

Рис. 6. Моделювання в розрахунковій моделі передання зусиль на циліндричну частину 30 від попереднього напруження в АК

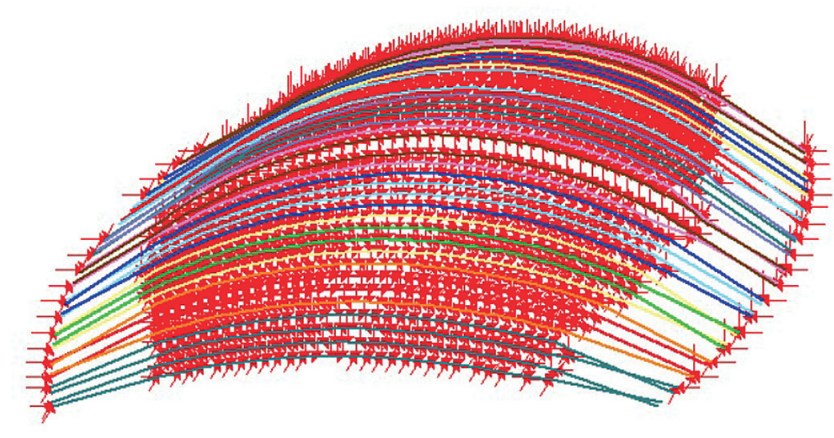

a

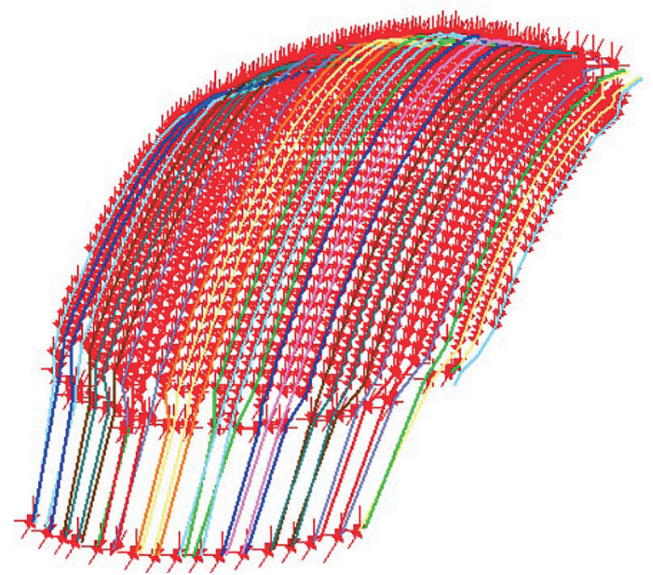

6

Рис. 7. Моделювання зусиль від АК у розрахунковій моделі купольної частини 3О: а - моделювання зусиль від АК нижнього шару купольної частини 3О; 6 - моделювання зусиль від АК верхнього шару купольної частини 30

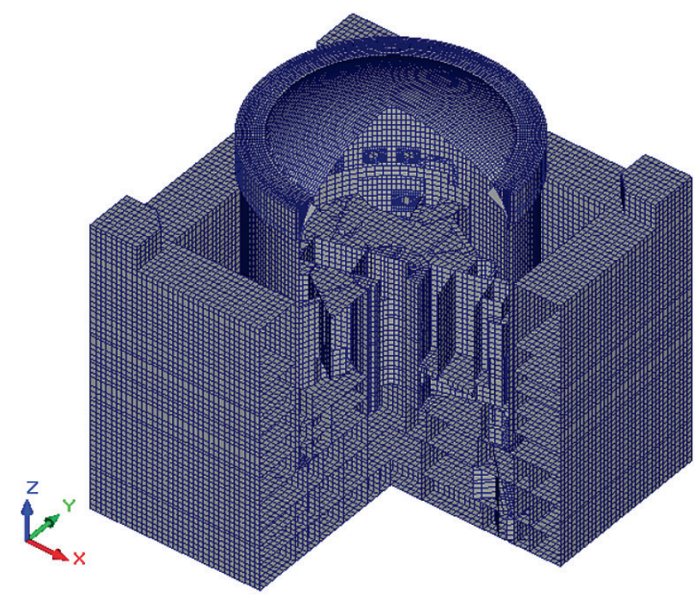

a

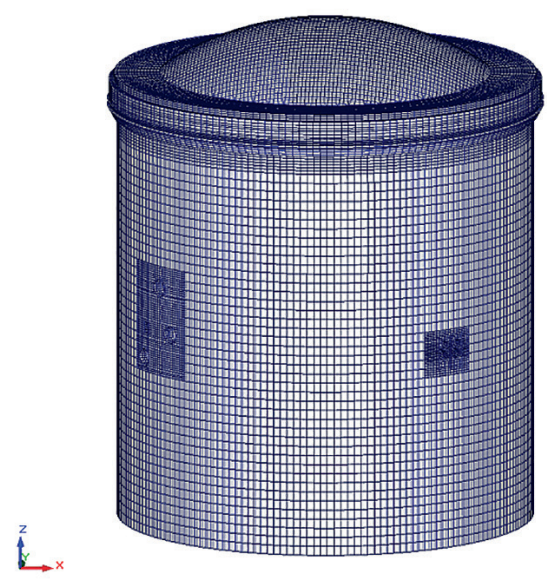

6

Рис. 8. Розрахункова модель реакторного відділення та 3О: а - загальний вигляд моделі; б - фрагмент загальної моделі 30 


\section{Критерії граничних станів ЗОК}

Протягом зміни температури і тиску герметичність і міцність ЗОК оцінюється за такими граничними станами:

критерій 1 - перехід від суцільного стану бетону до початку утворення та розкриття тріщин у залізобетоні;

критерій 2 - перехід від стабільного до інтенсивного утворення тріщин у залізобетоні, втрата герметичності ЗОК;

критерій 3 - перехід від інтенсивного утворення тріщин до повного руйнування залізобетону.

Внутрішні зусилля в розрахункових перерізах елементів ЗОК визначалися відповідно до ПНАЭ Г-10-007-89.

Умови виконання критерію 3 (руйнування) визначалися відповідно до ПНАЭ Г-10-007-89. При цьому коефіцієнти надійності при визначенні навантажень, характеристик міцності і деформацій приймалися такими, що дорівнюють одиниці.

Умови виконання критерію 2 (перехід до інтенсивного утворення тріщин) у ДБН В.2.6-98:2009 та в ДСТУ Б В.2.6-156:2010 не визначено. У таблиці 5.1 ДСТУ Б В.2.6-156:2010 визначені обмеження на розкриття тріщин з огляду на умови довговічності та прийнятного вигляду. У [1] було визначено граничне розкриття тріщини в стінці товщиною 1,2 м циліндричної частини ЗОК з огляду на умови втрати герметичності ЗОК. Граничне розкриття тріщини 1,6 мм. Але для дотримання стандартних положень, викладених в ДБН і ДСТУ, критерієм 2 приймаються граничні розкриття тріщин, які дорівнюють
0,4 мм за тимчасовими навантаженнями, що відповідають МПА.

Умови виконання критерію 1 (початок утворення тріщин) визначені в п. 5.2.1 ДСТУ Б В.2.6156:2010: «Напруження стиску в бетоні повинні обмежуватися для запобігання виникненню поздовжніх тріщин або високого рівня повзучості. Поздовжні тріщини можуть виникати, якщо рівень напружень при нормативному сполученні навантажень перевищує критичну величину. За відсутності інших заходів можливо обмежити напруження стиску до величини $k_{\nu} f_{c k}$. За відсутності більш точних даних величину $k_{1}$ рекомендується приймати $k_{1}=0,6 »$.

\section{Результати досліджень}

Дослідження з визначення мінімальних зусиль в АК, які забезпечують міцність і герметичність залізобетонних конструкцій 30 протягом 10 год МПА, були виконані разом з іншими заходами з перепризначення ресурсу 30 реакторного відділення № 4 Запорізької AEC $[1,2]$.

Дослідження граничних значень температури i надлишкового тиску, які відповідають граничній несучій здатності перерізів 3ОК для циліндричної частини 30 за критеріями 1, 2, 3 за мінімальних зусиль в АК, які дорівнюють 7,8 МН для циліндра і 7,6 МН для купола, наведено в табл. 3-5.

Розрахункові та граничні значення зусиль у залізобетонних елементах ЛСБ визначено відповідно до процедури, викладеної в ПНАЭ Г-10-007-89 (рис. 9).

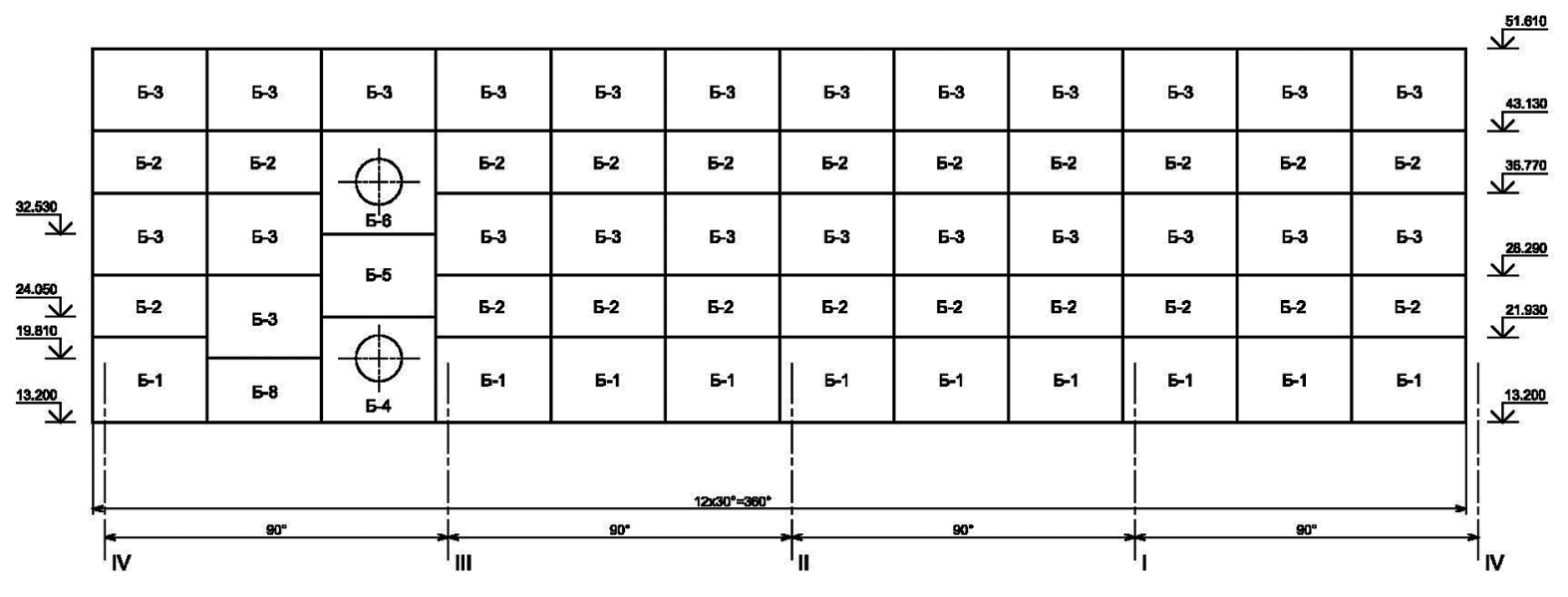

Рис. 9. Схема розкладки арматурних блоків циліндричної частини ЗОК 
Аналіз граничних значень температури і надлишкового тиску, які відповідають граничній несучій здатності перерізів для циліндричної частини (арматурний блок № 1) для позначки 13,20-24,05 у зоні перетину циліндра і опорної плити, наведено в табл. 3-5. Напівжирним шрифтом відзначені зусилля, що перевищують граничні значення за відповідними критеріями.

Таблиця 3. Для перерізів циліндричної частини (арматурний блок № 1) для позначки 13,20-24,05 за критерієм 1

\begin{tabular}{|c|c|c|c|c|}
\hline $\begin{array}{c}P, \text { тиск, } \\
\text { МПа }\end{array}$ & $0^{\circ} \mathrm{C}$ & $45^{\circ} \mathrm{C}$ & $65^{\circ} \mathrm{C}$ & $85^{\circ} \mathrm{C}$ \\
\hline $0 \mathrm{MПа}$ & 0 & $\begin{array}{l}N_{\max }=-8,66 ; \\
M_{\max }=3,30 ; \\
{\left[N_{\max }\right]=4,85 \text { при } 40-80^{\circ} \mathrm{C} ;} \\
{\left[M_{\max }\right]=4,85 \text { при } 40-80^{\circ} \mathrm{C}}\end{array}$ & $\begin{array}{l}N_{\max }=-12,26 ; \\
M_{\max }=\mathbf{5 , 8 0} \\
{\left[N_{\max }\right]=\mathbf{4 , 8 5} \text { при } 40-80^{\circ} \mathrm{C} ;} \\
{\left[M_{\max }\right]=\mathbf{4 , 8 5} \text { при } 40-80^{\circ} \mathrm{C}}\end{array}$ & $\begin{array}{l}N_{\max }=-15,86 ; \\
M_{\max }=\mathbf{8 , 5 8} ; \\
{\left[N_{\max }\right]=\mathbf{4 , 8 5} \text { при } 40-80^{\circ} \mathrm{C} ;} \\
{\left[M_{\max }\right]=\mathbf{4 , 8 5} \text { при } 40-80^{\circ} \mathrm{C}}\end{array}$ \\
\hline 0,3 МПа & $\begin{array}{l}N_{\max }=0,35 ; \\
M_{\max }=-1,13 ; \\
{\left[N_{\max }\right]=4,85 \text { при } 40-80^{\circ} \mathrm{C} ;} \\
{\left[M_{\max }\right]=4,85 \text { при } 40-80^{\circ} \mathrm{C}}\end{array}$ & $\begin{array}{l}N_{\max }=-8,08 ; \\
M_{\max }=5,12 ; \\
{\left[N_{\max }\right]=4,85 \text { при } 40-80^{\circ} \mathrm{C} ;} \\
{\left[M_{\max }\right]=4,85 \text { при } 40-80^{\circ} \mathrm{C}}\end{array}$ & $\begin{array}{l}N_{\max }=-11,68 ; \\
M_{\max }=7,90 ; \\
{\left[N_{\max }\right]=4,85 \text { при } 40-80{ }^{\circ} \mathrm{C} ;} \\
{\left[M_{\max }\right]=\mathbf{4 , 8 5} \text { при } 40-80^{\circ} \mathrm{C}}\end{array}$ & $\begin{array}{l}N_{\max }=-15,27 ; \\
M_{\max }=10,68 ; \\
{\left[N_{\max }\right]=4,85 \text { при } 40-80{ }^{\circ} \mathrm{C} ;} \\
{\left[M_{\max }\right]=4,85 \text { при } 40-80^{\circ} \mathrm{C}}\end{array}$ \\
\hline 0,4 МПа & $\begin{array}{l}N_{\max }=1,13 ; \\
M_{\max }=-0,43 ; \\
{\left[N_{\max }\right]=4,85 \text { при } 40-80{ }^{\circ} \mathrm{C} ;} \\
{\left[M_{\max }\right]=4,85 \text { при } 40-80{ }^{\circ} \mathrm{C}}\end{array}$ & $\begin{array}{l}N_{\max }=-7,89 ; \\
M_{\max }=\mathbf{5 , 8 2 ;} \\
{\left[N_{\max }\right]=\mathbf{4 , 8 5} \text { при } 40-80^{\circ} \mathrm{C} ;} \\
{\left[M_{\max }\right]=\mathbf{4 , 8 5} \text { при } 40-80^{\circ} \mathrm{C}}\end{array}$ & $\begin{array}{l}N_{\max }=-11,48 ; \\
M_{\max }=8,60 ; \\
{\left[N_{\max }\right]=4,85 \text { при } 40-80{ }^{\circ} \mathrm{C} ;} \\
{\left[M_{\max }\right]=\mathbf{4 , 8 5} \text { при } 40-80^{\circ} \mathrm{C}}\end{array}$ & $\begin{array}{l}N_{\max }=-15,08 ; \\
M_{\max }=11,38 ; \\
{\left[N_{\max }\right]=4,85 \text { при } 40-80{ }^{\circ} \mathrm{C} ;} \\
{\left[M_{\max }\right]=4,85 \text { при } 40-80^{\circ} \mathrm{C}}\end{array}$ \\
\hline 0,5 МПа & $\begin{array}{l}N_{\max }=1,98 ; \\
M_{\max }=0,26 ; \\
{\left[N_{\max }\right]=4,85 \text { при } 40-80{ }^{\circ} \mathrm{C} ;} \\
{\left[M_{\max }\right]=4,85 \text { при } 40-80^{\circ} \mathrm{C}}\end{array}$ & $\begin{array}{l}N_{\max }=-7,68 ; \\
M_{\max }=6,51 ; \\
{\left[N_{\max }\right]=4,85 \text { при } 40-80{ }^{\circ} \mathrm{C} ;} \\
{\left[M_{\max }\right]=\mathbf{4 , 8 5} \text { при } 40-80^{\circ} \mathrm{C}}\end{array}$ & $\begin{array}{l}N_{\max }=-11,28 ; \\
M_{\max }=9,29 ; \\
{\left[N_{\max }\right]=4,85 \text { при } 40-80{ }^{\circ} \mathrm{C} ;} \\
{\left[M_{\max }\right]=\mathbf{4 , 8 5} \text { при } 40-80^{\circ} \mathrm{C}}\end{array}$ & $\begin{array}{l}N_{\max }=-14,87 ; \\
M_{\max }=12,07 ; \\
{\left[N_{\max }\right]=4,85 \text { при } 40-80^{\circ} \mathrm{C} ;} \\
{\left[M_{\max }\right]=4,85 \text { при } 40-80^{\circ} \mathrm{C} ;}\end{array}$ \\
\hline
\end{tabular}

Таблиця 4. Для перерізів циліндричної частини (арматурний блок № 1) для позначки 13,20-24,05 за критерієм 2

\begin{tabular}{|c|c|c|c|c|}
\hline $\begin{array}{c}P, \text { тиск, } \\
\text { МПа }\end{array}$ & $0^{\circ} \mathrm{C}$ & $45^{\circ} \mathrm{C}$ & $65^{\circ} \mathrm{C}$ & $85^{\circ} \mathrm{C}$ \\
\hline $0 \mathrm{MПа}$ & 0 & $\begin{array}{l}N_{\max }=-8,66 ; \\
M_{\max }=3,30 ; \\
{\left[N_{\max }\right]=\mathbf{6 , 5} \text { при } 40-80^{\circ} \mathrm{C} ;} \\
{\left[M_{\max }\right]=6,5 \text { при } 40-80{ }^{\circ} \mathrm{C}}\end{array}$ & $\begin{array}{l}N_{\max }=-\mathbf{1 2 , 2 6} \\
M_{\max }=5,80 ; \\
{\left[N_{\max }\right]=\mathbf{6 , 5} \text { при } 40-80{ }^{\circ} \mathrm{C} ;} \\
{\left[M_{\max }\right]=6,5 \text { при } 40-80{ }^{\circ} \mathrm{C}}\end{array}$ & $\begin{array}{l}\boldsymbol{N}_{\max }=-\mathbf{1 5 , 8 6 ;} \\
\boldsymbol{M}_{\max }=\mathbf{8 , 5 8} ; \\
{\left[\boldsymbol{N}_{\max }\right]=\mathbf{6 , 5} \text { при } 40-80{ }^{\circ} \mathrm{C} ;} \\
{\left[\boldsymbol{M}_{\max }\right]=\mathbf{6 , 5} \text { при } 40-80{ }^{\circ} \mathrm{C}}\end{array}$ \\
\hline $0,3 \mathrm{MПа}$ & $\begin{array}{l}N_{\max }=0,35 ; \\
M_{\max }=-1,13 ; \\
{\left[N_{\max }\right]=6,5 \text { при } 40-80{ }^{\circ} \mathrm{C} ;} \\
{\left[M_{\max }\right]=6,5 \text { при } 40-80{ }^{\circ} \mathrm{C}}\end{array}$ & $\begin{array}{l}N_{\max }=-\mathbf{8 , 0 8} \\
M_{\max }=5,12 ; \\
{\left[N_{\max }\right]=\mathbf{6 , 5} \text { при } 40-80^{\circ} \mathrm{C} ;} \\
{\left[M_{\max }\right]=6,5 \text { при } 40-80^{\circ} \mathrm{C}}\end{array}$ & $\begin{array}{l}N_{\max }=-11,68 ; \\
M_{\max }=7,90 ; \\
{\left[N_{\max }\right]=\mathbf{6 , 5} \text { при } 40-80{ }^{\circ} \mathrm{C} ;} \\
{\left[M_{\max }\right]=\mathbf{6 , 5} \text { при } 40-80{ }^{\circ} \mathrm{C}}\end{array}$ & $\begin{array}{l}N_{\max }=-\mathbf{1 5 , 2 7} \\
M_{\max }=\mathbf{1 0 , 6 8 ;} \\
{\left[N_{\max }\right]=\mathbf{6 , 5} \text { при } 40-80{ }^{\circ} \mathrm{C} ;} \\
{\left[M_{\max }\right]=\mathbf{6 , 5} \text { при } 40-80{ }^{\circ} \mathrm{C}}\end{array}$ \\
\hline $0,4 \mathrm{MПа}$ & $\begin{array}{l}N_{\max }=1,13 ; \\
M_{\max }=-0,43 ; \\
{\left[N_{\max }\right]=6,5 \text { при } 40-80{ }^{\circ} \mathrm{C} ;} \\
{\left[M_{\max }\right]=6,5 \text { при } 40-80{ }^{\circ} \mathrm{C}}\end{array}$ & $\begin{array}{l}N_{\max }=-7,89 ; \\
M_{\max }=5,82 ; \\
{\left[N_{\max }\right]=6,5 \text { при } 40-80^{\circ} \mathrm{C} ;} \\
{\left[M_{\max }\right]=6,5 \text { при } 40-80{ }^{\circ} \mathrm{C}}\end{array}$ & $\begin{array}{l}N_{\max }=-\mathbf{1 1 , 4 8 ;} \\
M_{\max }=\mathbf{8 , 6 0} \\
{\left[N_{\max }\right]=\mathbf{6 , 5} \text { при } 40-80{ }^{\circ} \mathrm{C} ;} \\
{\left[\boldsymbol{M}_{\max }\right]=\mathbf{6 , 5} \text { при } 40-80{ }^{\circ} \mathrm{C}}\end{array}$ & $\begin{array}{l}N_{\max }=-\mathbf{1 5 , 0 8 ;} \\
M_{\max }=\mathbf{1 1 , 3 8 ;} \\
{\left[N_{\max }\right]=\mathbf{6 , 5} \text { при } 40-80{ }^{\circ} \mathrm{C} ;} \\
{\left[M_{\max }\right]=6,5 \text { при } 40-80{ }^{\circ} \mathrm{C}}\end{array}$ \\
\hline $0,5 \mathrm{MПа}$ & $\begin{array}{l}N_{\max }=1,98 ; \\
M_{\max }=0,26 ; \\
{\left[N_{\max }\right]=6,5 \text { при } 40-80{ }^{\circ} \mathrm{C} ;} \\
{\left[M_{\max }\right]=6,5 \text { при } 40-80{ }^{\circ} \mathrm{C}}\end{array}$ & $\begin{array}{l}N_{\max }=-7,68 ; \\
M_{\max }=\mathbf{6 , 5 1} ; \\
{\left[N_{\max }\right]=\mathbf{6 , 5} \text { при } 40-80{ }^{\circ} \mathrm{C} ;} \\
{\left[\boldsymbol{M}_{\max }\right]=\mathbf{6 , 5} \text { при } 40-80^{\circ} \mathrm{C}}\end{array}$ & $\begin{array}{l}N_{\max }=-\mathbf{1 1 , 2 8} \\
M_{\max }=\mathbf{9 , 2 9} \\
{\left[N_{\max }\right]=\mathbf{6 , 5} \text { при } 40-80{ }^{\circ} \mathrm{C} ;} \\
{\left[M_{\max }\right]=\mathbf{6 , 5} \text { при } 40-80{ }^{\circ} \mathrm{C}}\end{array}$ & $\begin{array}{l}N_{\max }=-\mathbf{1 4 , 8 7} ; \\
M_{\max }=\mathbf{1 2 , 0 7 ;} \\
{\left[N_{\max }\right]=\mathbf{6 , 5} \text { при } 40-80{ }^{\circ} \mathrm{C} ;} \\
{\left[M_{\max }\right]=\mathbf{6 , 5} \text { при } 40-80{ }^{\circ} \mathrm{C}}\end{array}$ \\
\hline
\end{tabular}


Таблиця 5. Для перерізів циліндричної частини (арматурний блок № 1) для позначки 13,20-24,05 за критерієм 3

\begin{tabular}{|c|c|c|c|c|}
\hline $\begin{array}{c}P, \text { тиск, } \\
\text { МПа }\end{array}$ & $0^{\circ} \mathrm{C}$ & $45^{\circ} \mathrm{C}$ & $65^{\circ} \mathrm{C}$ & $85^{\circ} \mathrm{C}$ \\
\hline $0 \mathrm{M \Pi а}$ & 0 & $\begin{array}{l}N_{\max }=-8,66 ; \\
M_{\max }=3,30 ; \\
{\left[N_{\max }\right]=8,1 \text { при } 40-80^{\circ} \mathrm{C} ;} \\
{\left[M_{\max }\right]=8,1 \text { при } 40-80^{\circ} \mathrm{C}}\end{array}$ & $\begin{array}{l}N_{\max }=-12,26 ; \\
M_{\max }=5,80 ; \\
{\left[N_{\max }\right]=8,1 \text { при } 40-80^{\circ} \mathrm{C} ;} \\
{\left[M_{\max }\right]=8,1 \text { при } 40-80^{\circ} \mathrm{C}}\end{array}$ & $\begin{array}{l}N_{\max }=-\mathbf{1 5 , 8 6 ;} \\
M_{\max }=\mathbf{8 , 5 8 ;} \\
{\left[N_{\max }\right]=\mathbf{8 , 1} \text { при } 40-80^{\circ} \mathrm{C} ;} \\
{\left[M_{\max }\right]=\mathbf{8 , 1} \text { при } 40-80^{\circ} \mathrm{C}}\end{array}$ \\
\hline 0,3 МПа & $\begin{array}{l}N_{\max }=0,35 ; \\
M_{\max }=-1,13 ; \\
{\left[N_{\max }\right]=8,1 \text { при } 40-80^{\circ} \mathrm{C} ;} \\
{\left[M_{\max }\right]=8,1 \text { при } 40-80^{\circ} \mathrm{C}}\end{array}$ & $\begin{array}{l}N_{\max }=-8,08 ; \\
M_{\max }=5,12 ; \\
{\left[N_{\max }\right]=8,1 \text { при } 40-80^{\circ} \mathrm{C} ;} \\
{\left[M_{\max }\right]=8,1 \text { при } 40-80^{\circ} \mathrm{C}}\end{array}$ & $\begin{array}{l}N_{\max }=-11,68 ; \\
M_{\max }=7,90 ; \\
{\left[N_{\max }\right]=8,1 \text { при } 40-80^{\circ} \mathrm{C} ;} \\
{\left[M_{\max }\right]=8,1 \text { при } 40-80^{\circ} \mathrm{C}}\end{array}$ & $\begin{array}{l}N_{\max }=-15,27 ; \\
M_{\max }=10,68 ; \\
{\left[N_{\max }\right]=8,1 \text { при } 40-80^{\circ} \mathrm{C} ;} \\
{\left[M_{\max }\right]=8,1 \text { при } 40-80^{\circ} \mathrm{C}}\end{array}$ \\
\hline $0,4 \mathrm{MПа}$ & $\begin{array}{l}N_{\max }=1,13 ; \\
M_{\max }=-0,43 ; \\
{\left[N_{\max }\right]=8,1 \text { при } 40-80^{\circ} \mathrm{C} ;} \\
{\left[M_{\max }\right]=8,1 \text { при } 40-80^{\circ} \mathrm{C}}\end{array}$ & $\begin{array}{l}N_{\max }=-7,89 ; \\
M_{\max }=5,82 ; \\
{\left[N_{\max }\right]=8,1 \text { при } 40-80^{\circ} \mathrm{C} ;} \\
{\left[M_{\max }\right]=8,1 \text { при } 40-80^{\circ} \mathrm{C}}\end{array}$ & $\begin{array}{l}N_{\max }=-11,48 ; \\
M_{\max }=8,60 ; \\
{\left[N_{\max }\right]=8,1 \text { при } 40-80^{\circ} \mathrm{C} ;} \\
{\left[M_{\max }\right]=8,1 \text { при } 40-80^{\circ} \mathrm{C}}\end{array}$ & $\begin{array}{l}N_{\max }=-15,08 ; \\
M_{\max }=\mathbf{1 1 , 3 8 ;} \\
{\left[N_{\max }\right]=8,1 \text { при } 40-80^{\circ} \mathrm{C} ;} \\
{\left[M_{\max }\right]=\mathbf{8 , 1} \text { при } 40-80^{\circ} \mathrm{C}}\end{array}$ \\
\hline 0,5 МПа & $\begin{array}{l}N_{\max }=1,98 ; \\
M_{\max }=0,26 ; \\
{\left[N_{\max }\right]=8,1 \text { при } 40-80^{\circ} \mathrm{C} ;} \\
{\left[M_{\max }\right]=8,1 \text { при } 40-80^{\circ} \mathrm{C}}\end{array}$ & $\begin{array}{l}N_{\max }=-7,68 \\
M_{\max }=6,51 \\
{\left[N_{\max }\right]=8,1 \text { при } 40-80^{\circ} \mathrm{C} ;} \\
{\left[M_{\max }\right]=8,1 \text { при } 40-80^{\circ} \mathrm{C}}\end{array}$ & $\begin{array}{l}N_{\max }=-11,28 ; \\
M_{\max }=9,29 ; \\
{\left[N_{\max }\right]=8,1 \text { при } 40-80{ }^{\circ} \mathrm{C} ;} \\
{\left[M_{\max }\right]=8,1 \text { при } 40-80{ }^{\circ} \mathrm{C}}\end{array}$ & $\begin{array}{l}N_{\max }=-14,87 ; \\
M_{\max }=12,07 ; \\
{\left[N_{\max }\right]=8,1 \text { при } 40-80^{\circ} \mathrm{C} ;} \\
{\left[M_{\max }\right]=8,1 \text { при } 40-80^{\circ} \mathrm{C}}\end{array}$ \\
\hline
\end{tabular}

\section{Висновки}

Установлено, що мінімальні зусилля (нетто) в арматурних канатах циліндра захисної оболонки реактора становлять 7,8 $\mathrm{MH}$, а в арматурних канатах купола - 7,6 МН, що необхідно для забезпечення міцності і герметичності залізобетонних конструкцій циліндричної частини захисної оболонки реактора ВВЕР-1000 для всіх можливих комбінацій температур і надлишкового тиску протягом 10 год максимальної проектної аварії.

\section{Список використаної літератури}

1. Выполнение расчетного обоснования надежности СГО ЛСБ энергоблока № 4 на соответствие требованиям действующих НД по определению допустимых усилий натяжения арматурных канатов СПЗО : отчет о НИР (этап 1, ред. 3) / КИЭП. - 181712.218.001РК00 ; Инв № 518-Р/1-518/3.

2. Выполнение расчетного обоснования надежности СГО ЛСБ энергоблока № 4 на соответствие требованиям действующих НД по определению допустимых усилий натяжения арматурных канатов СПЗО : отчет о НИР (этап 2, ред. 1) / КИЭП. - 181712.218.002РК00 ; Инв № 522-Р. - Киев, 2018.

\section{Т. И. Матченко, Т. Ю. Верюжский, Н. А. Сирота, Л. Б. Шамис}

АО «Киевский научно-исследовательский и проектноконструкторский институт "Энергопроект"”, просп. Победьь, 4, г. Киев, 01135, Украина

\section{Анализ прочности защитной оболочки реактора при изменениях температуры и давления, вызванных аварией}

Разработана расчетная модель защитной оболочки и реакторного отделения в целом с использованием оболочечных конечных элементов на базе расчетного комплекса SCAD, которая позволяет задавать любые усилия в любом из 36 арматурных канатов купола и в любом из 96 арматурных канатов цилиндра защитной оболочки. Определены расчетом усилия в арматурных канатах, которые обеспечивают прочность и герметичность железобетонных конструкций защитной оболочки при максимальной проектной аварии для всех комбинации температур и избыточных давлений в течение 10 ч аварии.

Ключевые слова: защитная оболочка, герметичное ограждение, локализирующие системы безопасности, максимальная проектная авария, арматурный канат. 


\section{T. I. Matchenko, T. Yu. Veryuzhskaya, N. O. Sirota, L. B. Shamis}

JSC "Kyiv Research and Design Institute 'Energoproject”, 4, Peremohy av., Kyiv, 01135, Ukraine

\section{Analysis of the Strenght of the Protective Shell of the Reactor with the Change of Temperature and Pressure Caused by the Accident}

A containment shell (CS) is used in the localizing safety systems (LSS) and in the sealed enclosure (SE) of the NPP reactor buildings with VVER-1000 reactors to prevent the release of radioactive substances from the reactor building into the environment in the case of a reactor or steam line accident.

The reinforced concrete structures of the dome and the cylindrical part of the CS are prestressed with steel strands (PS) to provide the strength and tightness of the CS in the case of an accident.

When the strands are tensioned with a force creating stresses in the wires that exceed the low cycle fatigue strength of steel, stress relaxation occurs (loss of forces in the strands) during the operation, which makes it necessary to tension periodically the strands to the design values of the forces. The length of the strand wires increases during the tensioning, which reduces their deformation limit. When the deformation limit is exceeded due to the tensioning of the PS, they can rupture, even if the stress does not exceed the yield strength of steel.

The task is to calculate such minimum forces in the PS of the dome and the cylindrical part of the CS that will provide the strength and tightness of the CS in the case of a maximum design basis accident and to create stresses in the PS wires not exceeding the low cycle fatigue strength of steel, or, even better, not exceeding the high cycle fatigue strength of steel.

The design model of the protective shell and the reactor compartment in general with the use of shell finite elements on the basis of SCAD SC is developed, which allows you to set any effort in any of 36 reinforcing ropes dome and in any of
96 reinforcing ropes containment cylinder. The calculation of the effort in the reinforcing rope, which provides the strength and tightness of reinforced concrete structures with maximum design basis accident for all combinations of temperatures and excess pressure during 10 hours of the accident. The magnitudes of the forces in the reinforcing ropes, which ensure the strength of reinforced concrete structures in the event of a maximum design basis accident, are determined. It was established that the minimum forces (net) in the reinforcing ropes of the cylinder of the protective shell of the reactor are 7.8 $\mathrm{MN}$, and in the $\mathrm{AK}$ dome are 7.6 MN., which provide the strength and tightness of the reinforced concrete structures of the cylindrical part of the protective shell of the reactor VVER-1000 for all possible combinations of temperatures and overpressure within 10 hours of maximum design basis accident.

Keywords: protective shell, hermetic fencing, localizing security systems, maximum design basis accident, reinforcing rope.

\section{References}

1. Research effort report "Implementation of the design justification of the reliability of sealed enclosure system - safety localization system of the power unit no. 4 for compliance with the requirements of the existing regulatory documents (to determine the allowable tension forces of reinforcing ropes containment preloading system)". Stage 1, rev. 3, 181712.218.001PK00, inv. no 518-P/1-518/3. Kyiv Research and Design Institute "Energoproject". (in Russ.)

2. Research effort report "Implementation of the design justification of the reliability of sealed enclosure system - safety localization system of the power unit no. 4 for compliance with the requirements of the existing regulatory documents (to determine the allowable tension forces of reinforcing ropes containment preloading system)". Stage 1, rev. 3, 181712.218.002PK00, inv. no 522-P. Kyiv Research and Design Institute “Energoproject”. (in Russ.)

Надійшла 24.01.2019

Received 24.01.2019 


\section{В. А. Куров, В. О. Посох, Т. В. Пирогов}

ГП «Государственный научно-инженерный иентр систем контроля и аварийного реагирования», просп. Героев Сталинграда, 64/56, г. Киев, 04213, Украина

\section{Разработка и реализация компенсирующих мероприятий по обеспечению сейсмостойкости оборудования и трубопроводов систем, важных для безопасности}

\author{
Ключевые слова: \\ атомная электростанция, \\ компенсирующие мероприятия, \\ проектно-сметная документация, \\ сейсмостойкость, \\ максимальное расчетное \\ землетрясение, \\ техническое решение.
}

\begin{abstract}
Рассмотрены основные подходы к реализации компенсирующих мероприятий по обеспечению сейсмостойкости оборудования и трубопроводов систем, важных для безопасности на примере энергоблока № 1 ОП «Хмельницкая атомная электростанция». Представлены основные варианты технических решений, направленных на повышение сейсмостойкости оборудования и трубопроводов. Обоснование технических решений выполняется расчетным анализом с использованием современных программных кодов.
\end{abstract}

\section{Введение}

Сейсмическая безопасность существующих атомных электростанций (АЭС) признана одной из наиболее важных задач анализа безопасности.

Основной целью сейсмической квалификации существующих АЭС с водо-водяным энергетическим реактором (ВВЭР) является повышение сейсмической безопасности до уровня, рекомендуемого международным сообществом и в соответствии со стандартами Международного агентства по атомной энергии (МАГАТЭ).

В соответствии с постановлением коллегии Госатомрегулирования № 13 [1], необходимо подтверждение стойкости к сейсмическим воздействиям уровня 7 баллов по шкале MSK-64, но не меньше 0,1 g в соответствии с нормами [2]. Таким образом, в рамках реализации мероприятий Комплексной сводной программы повышения уровня безопасности энергоблоков атомных электростанций (КсПБ), выполнены мероприятия № 10101 «Разработка материалов и выполнение квалификации элементов энергоблока» и№ 18101 «Обеспечениесейсмостойкости систем и строительных конструкций».

\section{Исходные события для реализации мероприятий по повышению сейсмостойкости}

Для продления эксплуатации в сверхпроектный период энергоблока № 1 ОП «Хмельницкая АЭС» в рамках реализации мероприятий КсПБ № 10101 для ряда оборудования, важного для безопасности, выполнена квалификация на сейсмические воздействия на основе анализа опыта предыдущих землетрясений с использованием процедуры GIP-BBЭP [3, 4].

По результатам оценки сейсмостойкости важного для безопасности оборудования методом GIP-BBЭP (визуальной инспекции) были обнаружены недостатки (замечания) двух категорий: легкоустранимые замечания и замечания, требующие разработки и реализации компенсирующих мероприятий.

В случае легкоустранимых замечаний меропри-ятия по повышению сейсмостойкости оборудования представляют собой незначительные доработки в части анкеровки и закрепления оборудования и выполняются персоналом АЭС без разработки проектной документации.

Для замечаний, требующих разработки и реализации компенсирующих мероприятий, необхо-

(C) В. А. Куров, В. О. Посох, Т. В. Пирогов, 2019 
димо выполнять техническое переоснащение с разработкой рабочей проектной документации. В даннуюкатегориюзамечаний попадает оборудование с недостатками, связанными с недостаточно жесткой несущей конструкцией, на которой оборудование закреплено, или которая должна обеспечивать жёсткое соединение с несущей строительной конструкцией, a также сейсмическими взаимодействиями с расположенным в непосредственной близости дополнительным оборудованием, трубопроводами, конструкциями.

Для устранения вышеприведенных замечаний разрабатываются компенсирующие мероприятия: проектирование и изготовление сейсмостойкой несущей конструкции для надежного закрепления на ней оборудования; сейсмическая оценка дополнительного оборудования/конструкции (например, расчёт сейсмостойкости); взаимное раскрепление; устранение дополнительного оборудования/конструкций; разработка специальных дополнений к инструкции по эксплуатации такого оборудования и т. п.

В рамках реализации мероприятий КсПБ № 18101 для трубопроводов систем, важных для безопасности, выполнена оценка сейсмостойкости расчетным анализом в соответствии с действующими нормами Украины $[2,5,6]$ с учетом положений методики граничной сейсмостойкости [7].

Оценка сейсмостойкости показала, что некоторые участки трубопроводов не соответствуют критериям прочности при одновременном воздействии технологических нагрузок при нормальной эксплуатации (НЭ) и максимальном расчетном землетрясении (MP3) уровня 7 баллов (0,1 g) по шкале MSK-64. Компенсирующими мероприятиями в таких случаях является либо ослабление существующей опоры трубопровода (например, замена неподвижной жесткой опоры на направляющую), либо установка дополнительной опоры трубопровода в наиболее критическом месте.

Таким образом, по результатам оценки сейсмостойкости и квалификации на сейсмические воздействия для энергоблока № 1 Хмельницкой АЭС определен перечень позиций, для которых необходимо разработать проектную документацию и выполнить компенсирующие мероприятия по обеспечению сейсмостойкости. На рис. 1 представлена блок-схема, результирующая мероприятия по обеспечению сейсмостойкости оборудования и трубопроводов.

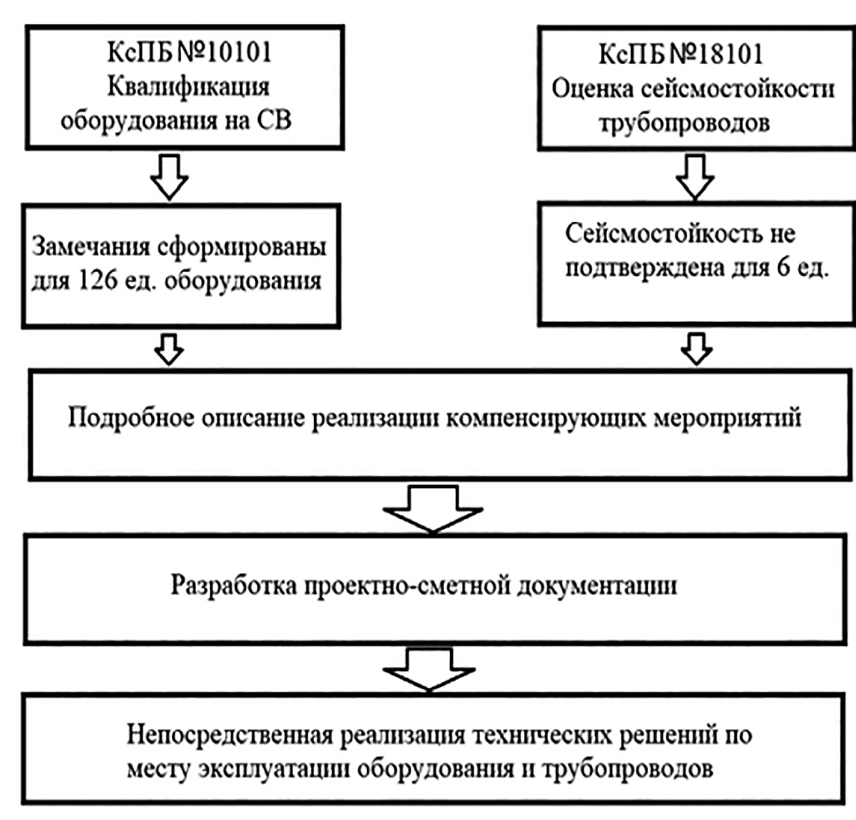

Рис. 1. Блок-схема выполнения мероприятий по обеспечению сейсмостойкости оборудования и трубопроводов

\section{Разработка рабочей проектной документации}

Рабочая проектная документация разрабатывается в соответствии с действующими нормами Украины [8-10] и состоит из рабочих чертежей, сметной документации (локальная смета, ведомость производственных расходов) и пояснительной записки с описанием реализации технического решения.

Рабочие чертежи выполняются для выбранных вариантов технического решения компенсирующих мероприятий. Например, если для повышения сейсмостойкости необходимо установить дополнительную опорную конструкцию трубопровода или оборудования, рабочие чертежи должны содержать подробное описание новой дополнительной опоры.

Из описанных выше типов замечаний следует, что основными техническими решениями для повышения сейсмостойкости оборудования и трубопроводов являются:

разработка дополнительной опорной металлоконструкции трубопровода;

разработка дополнительной опорной металлоконструкции трубопроводной арматуры;

взаимное раскрепление трубопроводов, арматур, арматуры и конструкции, трубопровода и конструкции;

устранение дополнительной конструкции, с которой взаимодействует оборудование. 
Далее рассмотрены примеры реализации компенсирующих мероприятий для повышения сейсмостойкости трубопроводных арматур и трубопроводов систем, важных для безопасности энергоблока № 1 Хмельницкой АЭС.

\section{Разработка дополнительной опорной металлоконструкции трубопровода}

Для оценки сейсмостойкости трубопроводов построена расчетная конечно-элементная модель. Расчет на сейсмические воздействия выполнялся линейно-спектральным методом с учетом собственных форм колебаний трубопроводов. Сейсмические нагрузки определялись с использованием поэтажных спектров ответа уровня МР3 для отметки $(+40,900 ;+36,900)$ реакторного отделения блока № 1 Хмельницкой АЭС для $2 \%$ демпфирования (рис. 2 и 3 ).

По результатам расчета на сейсмические воздействия определено, что участок трубопровода системы компенсации давления не удовлетворяет критериям прочности $1,8[\sigma]$ при комбинации нагружений НЭ + МР3 [2]. Распределение напряжений в рассматриваемом трубопроводе при НЭ + МР3 представлено на рис. 4. На выделенном участке напряжения достигают 230 МПа при допустимых $1,8[\sigma]=212$ МПа.

По результатам расчетного анализа с разными граничными условиями (дополнительные опоры различных типов: направляющая, скользящая, пружинная; различные места установки дополнительной опоры) оптимальным вариантом

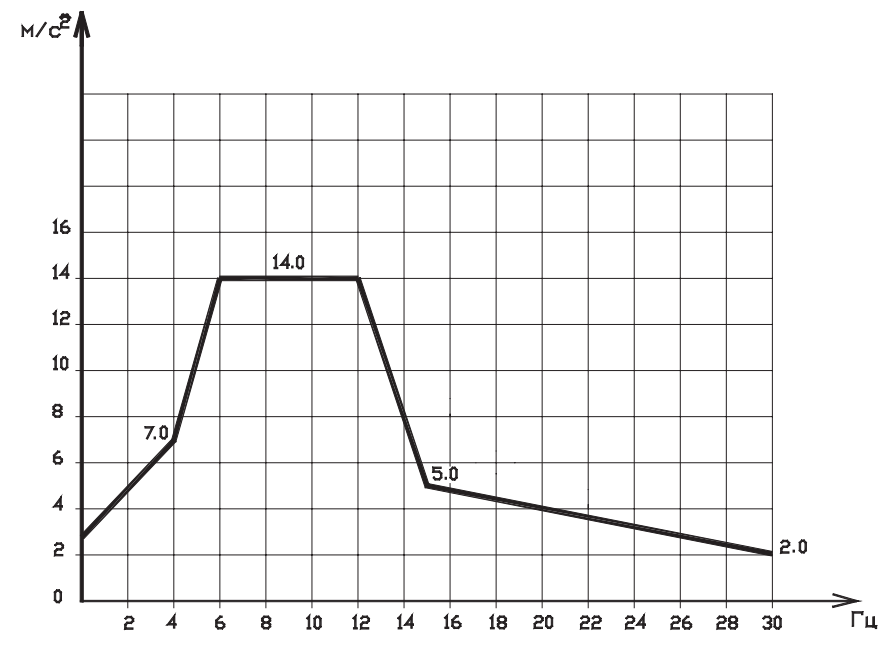

Рис. 2. Обобщенный спектр ответа при горизонтальных колебаниях

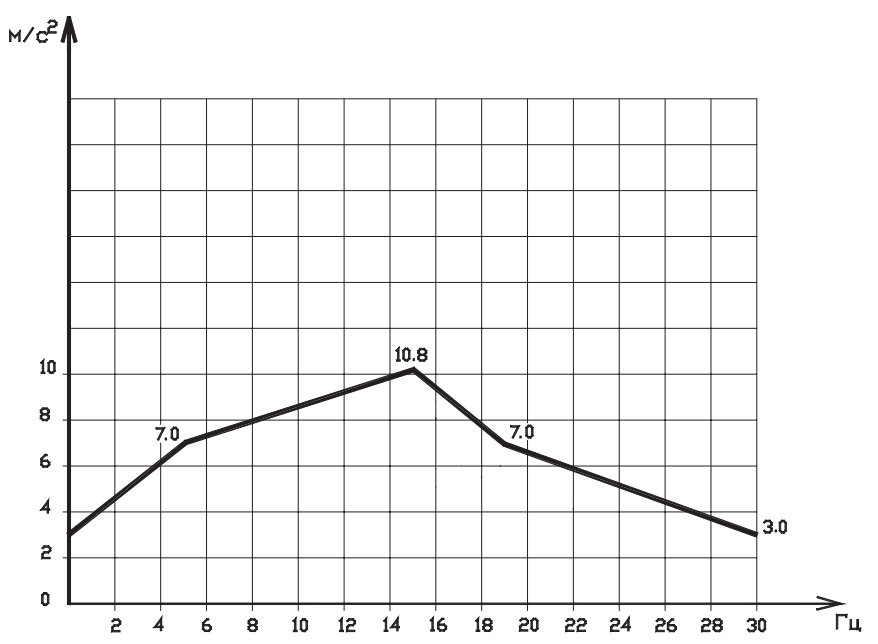

Рис. 3. Обобщенный спектр ответа при вертикальных колебаниях

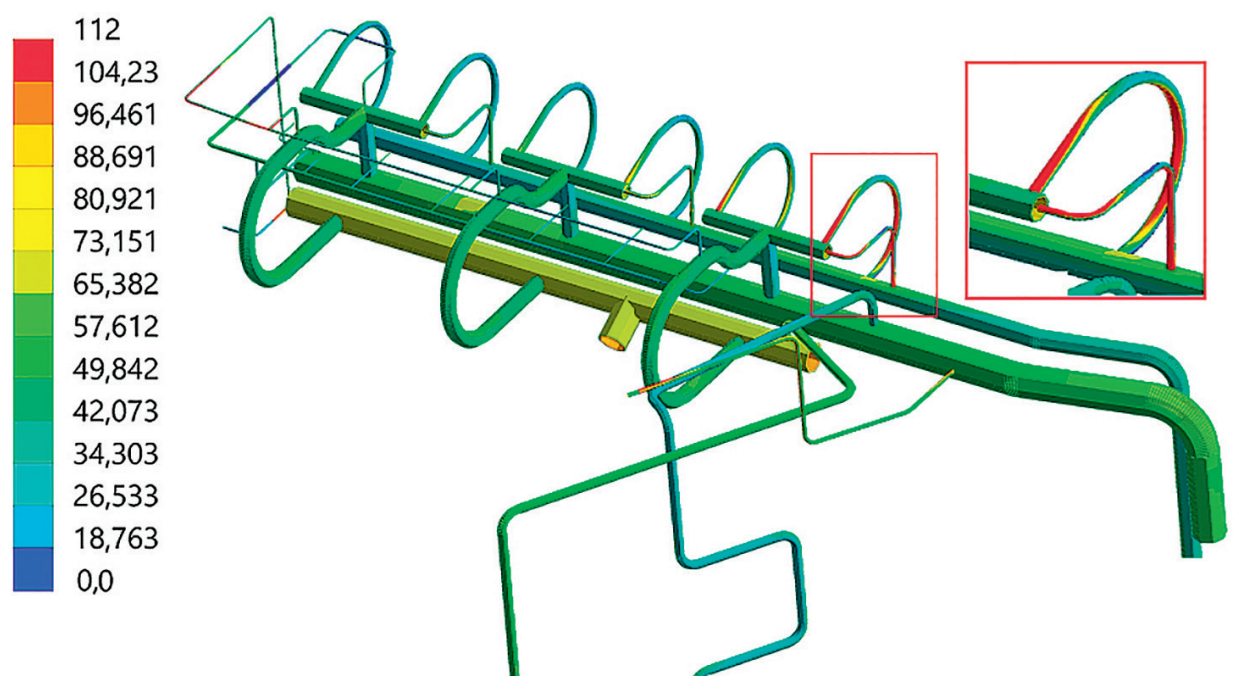

Рис. 4. Распределение напряжений в трубопроводе при НЭ + МР3, МПа 
повышения сейсмостойкости определена установка направляющей опоры трубопровода. По результатам визуальных осмотров по месту эксплуатации рассматриваемых трубопроводов выбрано точное место установки опоры, которую возможно присоединить к соседним металлоконструкциям. При этом металлоконструкции должны выдерживать дополнительные нагрузки, получаемые от веса опоры и трубопроводов, а также нагрузки при потенциальных сейсмических воздействиях уровня MP3 7 баллов по шкале MSK-64. По результатам расчета на прочность определена конфигурация опорнойметаллоконструкции с точными размерами, характеристиками материалов, типами соединения и т. д. Рабочий чертеж опорной металлоконструкции представлен на рис. 5.
Для подтверждения корректного выбора места установки опорной металлоконструкции выполнен дополнительный расчет трубопроводов, учитывающий трехмерную конечно-элементарную модель опорной металлоконструкции (рис. 6). Как видно из рисунка, напряжения в трубопроводе значительно уменьшились (50-60 МПа) по сравнению с расчетом без опоры (230 МПа). При этом нагрузки на саму опорную металлоконструкцию незначительны.

Таким образом, после установки дополнительной опорной металлоконструкции, разработанной на основании проектно-сметной документации, трубопровод будет устойчивым к сейсмическим воздействиям уровня MP3 7 баллов $(0,1 \mathrm{~g})$.

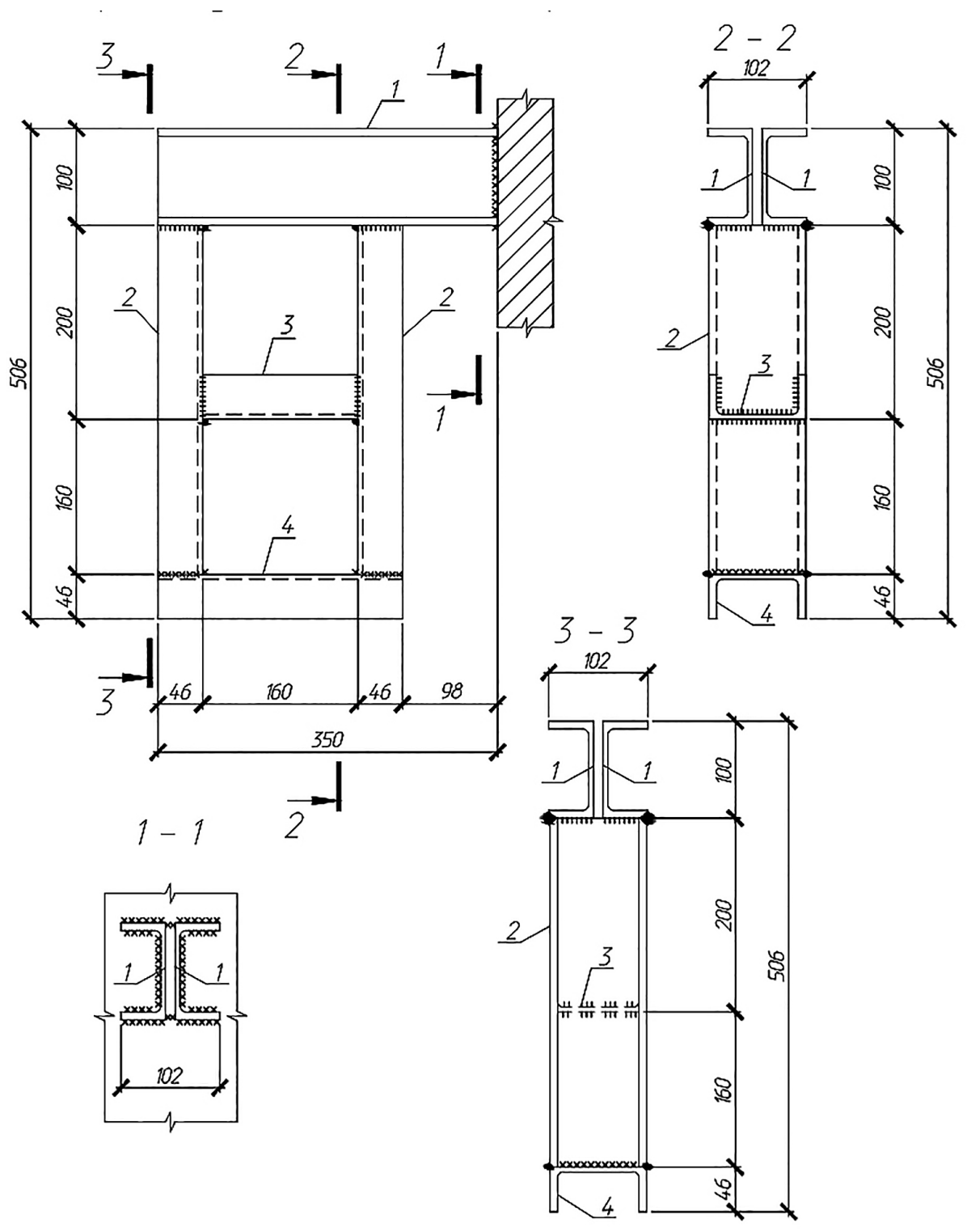

Рис. 5. Чертеж разработанной дополнительной опоры трубопровода 


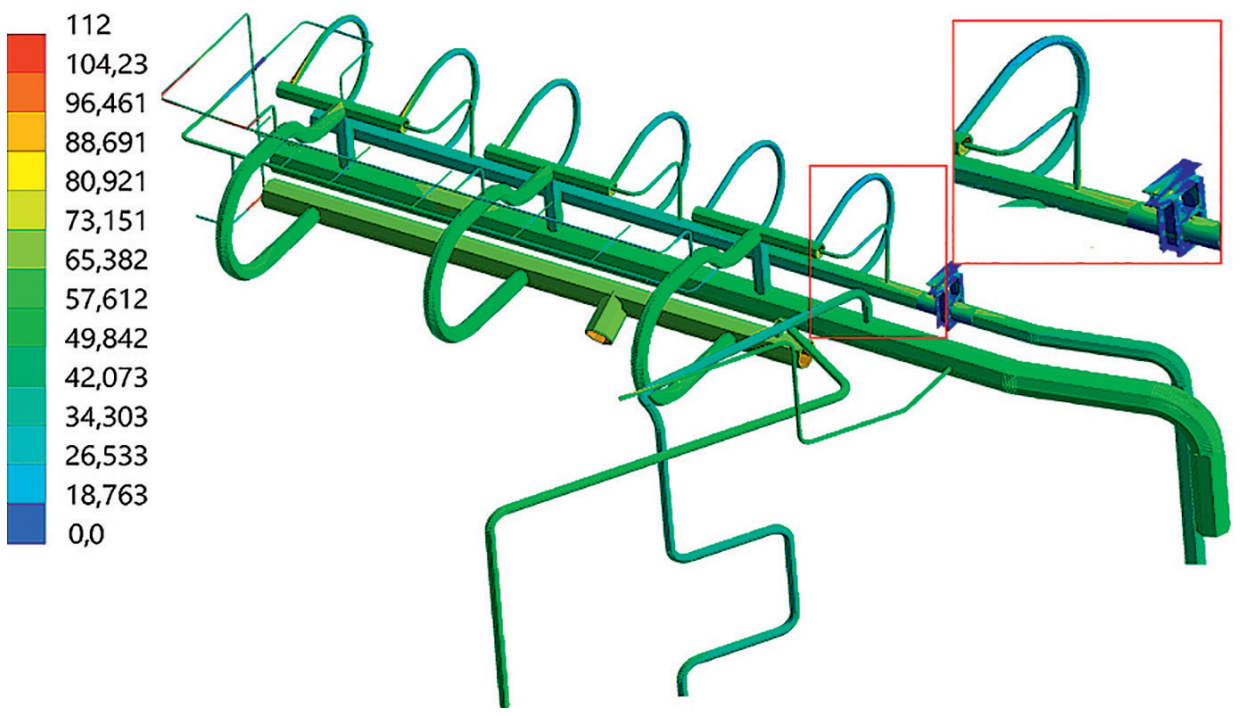

Рис. 6. Распределение напряжений в трубопроводе при НЭ + МРЗ с разработанной опорой, Мпа

\section{Компенсирующиемероприятия,направленные на устранение взаимодействия}

Как было сказано выше, одним из основных замечаний по результатам выполнения оценки сейсмостойкости оборудования, важного для безопасности, методом GIP-BBЭР является взаимодействие квалифицируемого оборудования с близлежащими элементами: трубопроводом, трубопроводной арматурой, воздуховодом, металлоконструкцией, элемен- тами оборудования (кабелями, защитными коробами, пультами управления и т. п.).

Основными путями решения вышеприведенной проблемы являются:

разработка дополнительной опорной металлоконструкции арматуры или трубопровода, на котором расположена арматура;

взаимное раскрепление арматуры с взаимодействующим элементом.

На рис. 7 представлен вариант взаимного рас-
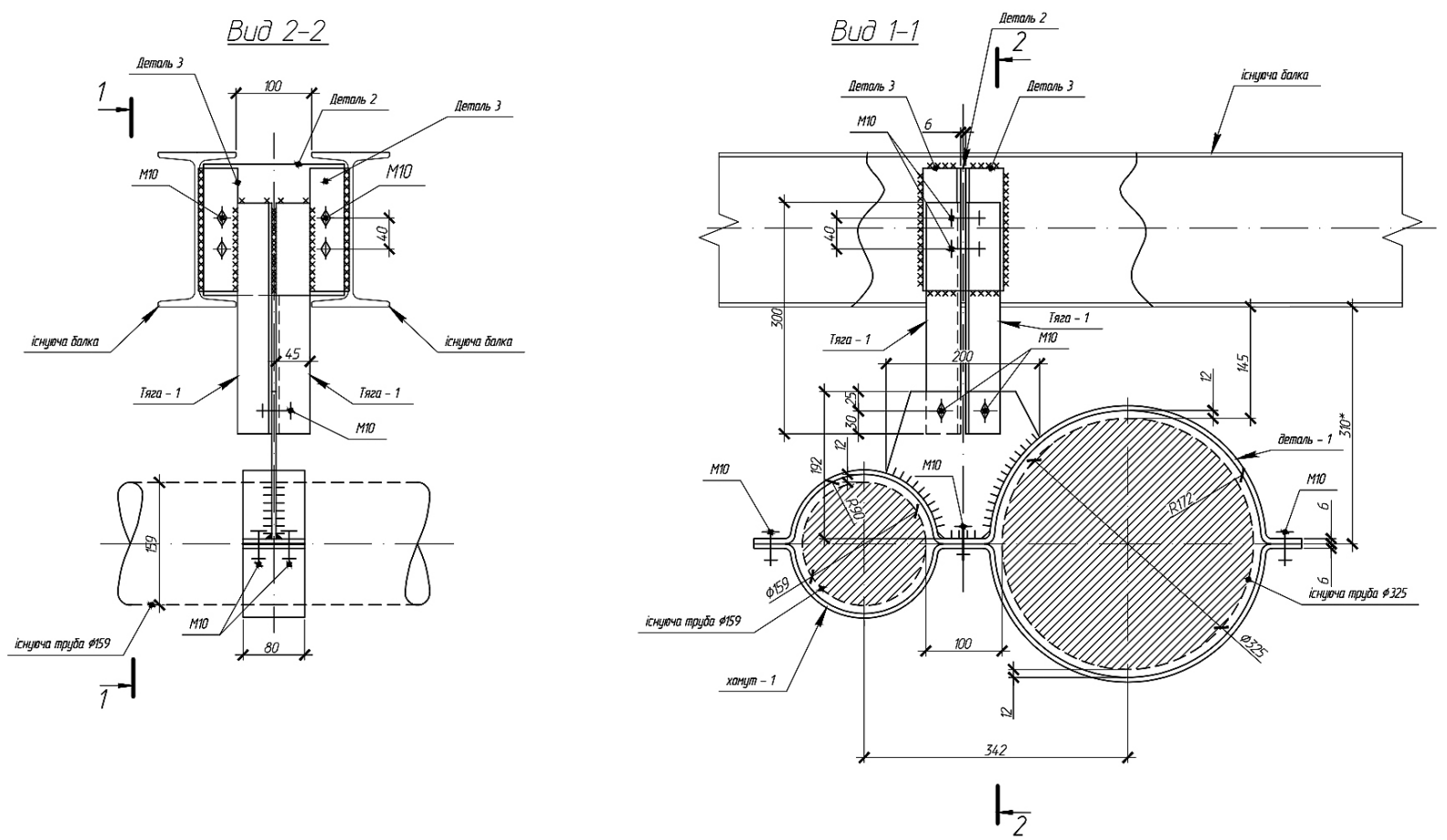

Рис. 7. Чертеж разработанной дополнительной опоры трубопроводов 


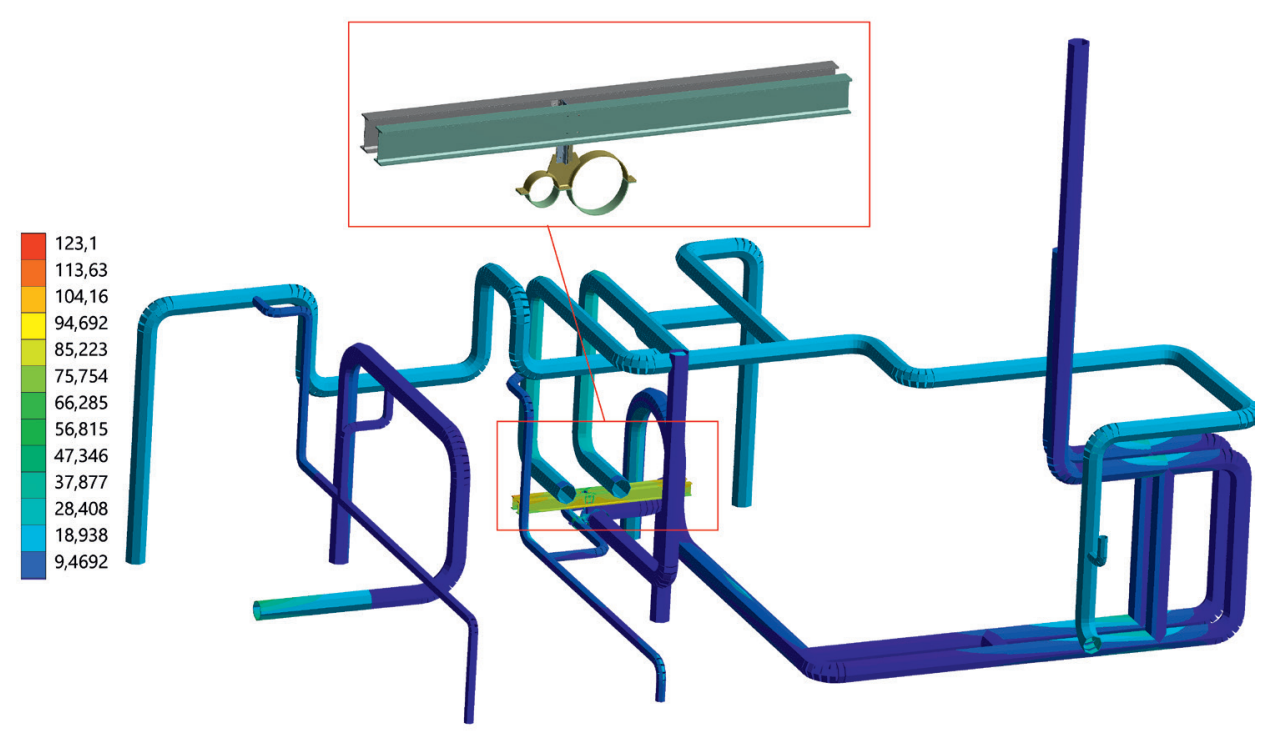

Рис. 8. Распределение напряжений в трубопроводе при НЭ + МР3 с разработанной опорой, МПа

крепления трубопроводов с помощью опорной металлоконструкции дляустранения взаимодействия трубопроводом диаметром 159 мм с трубопроводной арматурой, расположенной на расстоянии 500 мм от дополнительной опоры.

Аналогично описанному в предыдущем пункте подходу выполнен расчет на сейсмические воздействия при комбинации нагружений НЭ + MP3 с разработанной опорной металлоконструкцией. Как видно из рис. 8, напряжения в трубопроводах и опорной металлоконструкции незначительные (до $120 \mathrm{MПа}$ при допустимых $230 \mathrm{MПа).} \mathrm{При} \mathrm{этом} \mathrm{данная} \mathrm{кон-}$ струкция устраняет соударение как трубопроводов, так и арматуры с трубопроводом.

Таким образом, после установки дополнительной опорной металлоконструкции, разработанной на основании проектно-сметной документации, замечание по взаимодействию трубопровода с арматурой будет снято, так как опора обеспечит отсутствие перемещения трубопроводов (и соответственно арматуры) друг к другу, что делает арматуру устойчивой к сейсмическим воздействиям уровня MP3 7 баллов.

Наиболее простым и соответственно экономичным, но не менееэффективным способомустранения замечаний по взаимодействию трубопроводных арматур с соседними арматурами, трубопроводами, конструкциям является взаимное раскрепление. Такое техническое решение обеспечит взаимное перемещение элементов в одно и то же направление при сейсмическом воздействии, что исключит соударение элементов и, как следствие, выход из строя оборудования. Однако такое решение имеет ряд ограничений, связанных с местом эксплуатации оборудования, а также потенциального повышения напряжений в трубопроводах при перемещениях во время сейсмических воздействий, связанных с ограничениями, вызванными от взаимного раскрепления.

На рис. 9 представлены примеры взаимного раскрепления различных элементов.

\section{Заключение}

Действующие требования к сейсмостойкости $[2,11]$ оборудования и трубопроводов АЭС значительно повысились по сравнению с проектными требованиями, что связано в первую очередь с событиями, произошедшими на АЭС «ФукусимаДайичи».

По результатам работ по оценке сейсмостойкости ряд оборудования и трубопроводов не удовлетворяют действующим нормативным документам $[2,6,11]$. В результате чего установлена необходимость разработки компенсирующих мероприятий по повышению сейсмостойкости оборудования и трубопроводов, а следовательно и проектносметной документации для реализации данных мероприятий.

Для каждой единицы оборудования или трубо-провода индивидуально определяется техническое решение, исходя их условий эксплуатации, размещения, результатов поверочных расчетов.

В статье рассмотрены основные примеры технических решений, направленных на повышение сейсмостойкости трубопроводов и оборудования, 

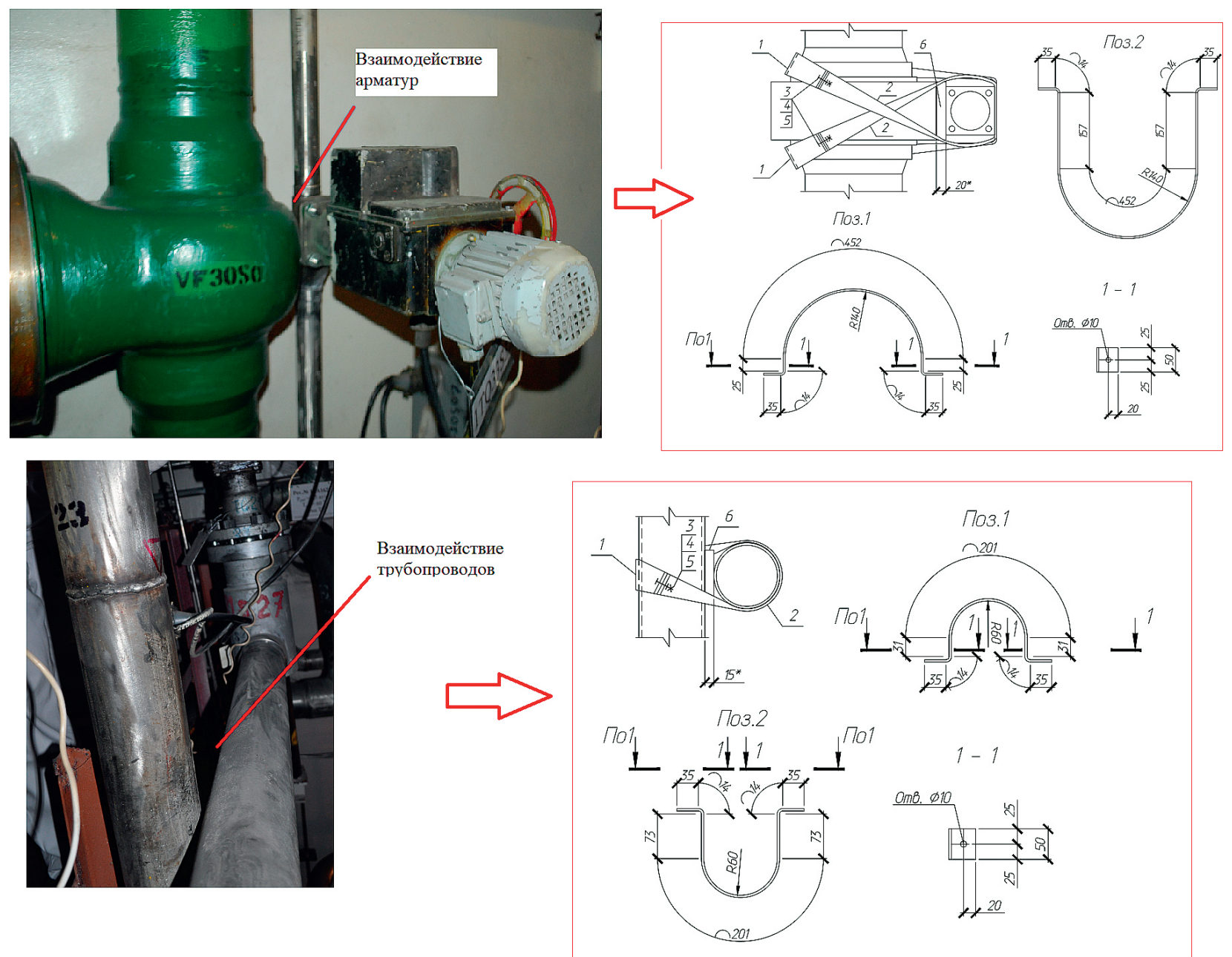

Рис. 9. Примеры взаимного раскрепления элементов оборудования и трубопроводов

в частности трубопроводных арматур. Так, основными решениями для повышения сейсмостойкости оборудования и трубопроводов являются: разработка дополнительной опорной металлоконструкции; взаимное раскрепление взаимодействующих элементов.

Эффективность выбора технического решения подтверждается расчетным анализом, выполненным в соответствии с действующими нормами Украины $[2,5,6]$.

\section{Список использованной литературы}

1. Постановление Коллегии Госатомрегулирования «О результатах выполнения целевой внеочередной оценки состояния безопасности действующих энергоблоков АЭС с учетом Фукусима-Даичи» от 24-25.11.2011 г. № 13 / Госатомрегулирования Украины. - 2011. Режим доступа: http://www.snrc.gov.ua/nuclear/uk/ publish/article/169634.

2. НП 306.2.208-2016. Вимоги до сейсмостійкого проек- тування та оцінки сейсмічної безпеки енергоблоків атомних станцій / Державна інспекція ядерного регулювання України // Офіційний вісник України. - 2016. № 92. - 59 c.

3. Generic Implementation Procedure (GIP) for Seismic Verification of Nuclear Power Plant Equipment. Revision 2A / SQUG [Seismic Qualification Utility Group], 1992. - 31 c.

4. DITI 300/376-RU/R.2. Методология оценки сейсмостойкости оборудования для целей квалификации на сейсмические воздействия / Институт ядерных исследований (г. Ржеж, Чешская Республика). - 2009. - 90 с.

5. ПНАЭ Г-7-002-86. Нормы расчета на прочность оборудования и трубопроводов атомных энергетических установок [Введены с изменениями 01.07.1987г.] / Госатомэнергонадзор СССР. - М. : Энергоатомиздат, 1989. - 525 c.

6. ДБН В.2.6-198:2014. Сталеві конструкції. Норми проектування / Мінрегіон України. - Київ : Укрархбудінформ, 2014. - 199 с.

7. МТ-Т.0.03.326-13. Методика расчетного анализа сейсмостойкости элементов действующих АЭС в 
рамках метода граничной сейсмостойкости / НАЭК «Энергоатом». - Київ, 2013. - 51 с.

8. ДБН А.2.2-3:2014. Склад, порядок розроблення, погодження та затвердження проектної документації для будівництва / Мінрегіон України. - Київ, 2014. - 33 с.

9. ДСТУ Б А.2.4-4:2009. Основні вимоги до проектної і робочої документації / Мінрегіон України. - Київ, 2009. - 66 c.

10. ДСТУ Б Д.1.1-1:2013. Правила визначення вартості будівництва / Мінрегіон України. - Київ, 2013. - 88 с.

11. ДБН В.1.1-12:2014. Будівництво у сейсмічних районах України/ Мінрегіон України. - Київ, 2014. - 110 с.

\section{В. О. Куров, В. О. Посох, Т. В. Пирогов}

ДП «Державний науково-інженерний иентр систем контрою та аварійного реагування», просп. Героїв Сталінграда, 64/56, м. Київ, 04213

\section{Розробка та реалізація компенсувальних заходів із забезпечення сейсмостійкості обладнання та трубопроводів систем, важливих для безпеки}

Розглянуто основні підходи до реалізації компенсувальних заходів із забезпечення сейсмостійкості обладнання і трубопроводів систем, важливих для безпеки на прикладі енергоблока № 1 ВП «Хмельницька атомна електростанція». Представлено основні варіанти технічних рішень, спрямованих на підвищення сейсмостійкості обладнання та трубопроводів. Обгрунтування технічних рішень виконано розрахунковим аналізом з використанням сучасних програмних кодів.

Ключові слова: атомна електростанція, компенсувальні заходи, проектно-кошторисна документація, сейсмостійкість, максимальний розрахунковий землетрус, технічне рішення.

\section{O. Kurov, V. O. Posokh, T. V. Pirogov}

State Enterprise "State Scientific Engineering Center of Control System and Emergency Response", 64/56, Geroiv Stalingrada ave, Kyiv, 04213, Ukraine

Development and implementation of compensating activities for providing the seismic resistance of equipment and pipelines of systems important for safety
One of the requirements for extending operation during the over-design period of NPP power units is to perform seismic resistance assessment (qualification for seismic effects) of equipment and pipelines of systems important to safety. According to the results of such work at power unit 1 of the Khmelnitsky Nuclear Power Plant for a number of equipment and pipelines, it is necessary to perform compensating activities aimed to increase seismic resistance. To implement compensating activities, it is necessary to develop technical solutions based on the design and estimate documentation.

The design and estimate documentation is developed in accordance with the current norms of Ukraine and consists of working drawings, estimate documentation (local estimate, statement of production costs) and an explanatory note describing the implementation of the technical solution.

Working drawings are performed for the selected options for the technical solution of compensating activities. For example, if to increase seismic resistance, it is necessary to install an additional support structure for the pipeline or equipment, the working drawings should contain a detailed description of the new additional support.

The main technical solutions for increasing the seismic resistance of equipment and pipelines are: development of an additional supporting metal pipeline; development of additional steel support for pipeline valves; mutual fastening of interacting elements; elimination of construction with interact of the equipment. The justification of technical solutions is performed by calculation analysis using modern software codes.

The article presents two examples of technical solutions: the development of additional support for the pipeline pressure compensation systems; mutual detachment of pipelines in order to avoid interaction of reinforcement with pipeline.

Keywords: nuclear power plant, compensating activities, design estimates documentation, seismic resistance, maximum calculated earthquake, technical solution.

\section{References}

1. Resolution of the Board of State Nuclear Regulatory Committee of the Ukraine "On the Results of the Implementation of the Target Extraordinary Assessment of the Safety Status of Operating NPP Units Taking into Account Fukushima-Daiichi" of November 24-25, 2011. Available at: http://www.snrc.gov.ua/nuclear/uk/publish/ article/169634. (in Russ.)

2. NP 306.2.208-2016. Requirements for Seismic Resistance Design and Evaluation of Seismic Safety of Ukrainian NPPs. Official Bulletin of Ukraine, 2016, no. 92, art. 59. (in Ukr.) 
3. Generic Implementation Procedure (GIP) for Seismic Verification of Nuclear Power Plant Equipment. Revision 2A / SQUG [Seismic Qualification Utility Group], 1992, 31 p.

4. DITI 300/376-RU/R.2. Methodology for assessing the seismic resistance of equipment for qualification for seismic effects. ÚJV Řež, 2009, 90 p. (in Russ.)

5. Gosatomonenergonadzor of the USSR (1989). PNAE G-7002-86. Standards for strength calculation of equipment and pipelines of nuclear power plants [introduced with changes of 07/01/1987]. Moscow: Energoatomizdat, 525 p. (in Russ.)

6. MinRegion of Ukraine (2014). DBN V.2.6-198: 2014. Steel structures. Design Standards. Kyiv: Ukrrahbudinform, 199 p. (in Ukr.)

7. SE "NNEGC "Energoatom" (2013). MT-T.0.03.326-13.
The method of calculation analysis of the seismic resistance of elements of operating NPPs in the framework of the boundary seismic resistance method. Kyiv, 51 p. (in Russ.)

8. DBN A.2.2-3:2014. Composition, procedure for development, approval and approval of project documentation for construction. Kyiv, Minregion of Ukraine, 2014, 33 p. (in Ukr.)

9. DSTU B A.2.4-4:2009. Basic requirements for design and working documentation. Kyiv: Minregion of Ukraine, 2009, 66 p. (in Ukr.)

10. DSTU B D.1.1-1:2013. Rules for determining the cost of construction. Kyiv, Minregion of Ukraine, 2013, 88 p. (in Ukr.)

11. DBN B.1.1-12:2014. Construction in seismic areas of Ukraine. Kyiv, Minregion of Ukraine, 2014, 110 p. (in Ukr.)

Надійшла 27.02.2019

Received 27.02.2019 


\section{T. I. Матченко}

AT «Київський науково-дослідний та проектно-конструкторський інститут "Енергопроект"», просп. Перемоги, 4, м. Київ, 01135, Україна

\section{Визначення реологічних змін полімерних каналів арматурних канатів}

Ключові слова:

арматурні канати, полімерні матеріали, реологічні зміни, довговічність, каналоутворювачі

\begin{abstract}
Оскільки у процесі роботи канати труться по стінках каналів захисної оболонки реакторного відділення атомної електростанції, з часом руйнуються полімерні каналоутворювачі і захисні трубки арматурних канатів. Для визначення коефіцієнта тертя в часі арматурних канатів між каналоутворювачами упродовж терміну роботи захисної оболонки, необхідно знати довговічність полімерних матеріалів каналоутворювача та полімерних трубок арматурних канатів. Для точного визначення нелінійних процесів деградації полімерів на підставі експериментальних досліджень необхідні методики виконання досліджень та обробки їх результатів. Такі методики відсутні в нормативних документах атомної енергетики і будівельної галузі в Україні. У статті запропонована методика визначення довговічності полімерних матеріалів після їх прискореного старіння за результатами випробування зразків на одновісне розтягнення і руйнування.
\end{abstract}

\section{Вступ}

Захисна оболонка (3О) реакторного відділення (РВ) атомної електростанції (АЕС) забезпечує герметичність внутрішніх приміщень під час максимальної проектної аварії, за якої підвищується надлишковий тиск і градієнт температури. Для забезпечення обтиснення залізобетонної 30 застосовуються арматурні канати (АК), які розташовані в полімерних каналоутворювачах. Розрахунки зусиль в АК, які забезпечують міцність і герметичність 30 4-го РВ Запорізької АЕС, виконані в $[4,5]$. Монтаж каналоутворювачів при будівництві 30 РВ показаний на рис. 1. Проміжки між АК (рис. 2) заповнені змазкою, яка зменшує втрати попереднього напруження від тертя.

Внаслідок натягнення АК забезпечується попереднє напруження стиснення в бетоні і недопущення розкриття тріщин при підвищенні тиску і температури під час аварії. За тривалої експлуатації відбувається релаксація напружень в АК, тому їх періодично підтягують. Під час підтягування АК труться по стінках каналів. Внаслідок цього з часом руйнуються полімерні каналоутворювачі та захисні трубки АК.

Для визначення втрат зусиль в АК внаслідок тертя по стінкам каналів необхідно знати, як змінюється в часі коефіцієнт тертя внаслідок старіння і руйнування полімерів каналу і трубок АК. Для визначення

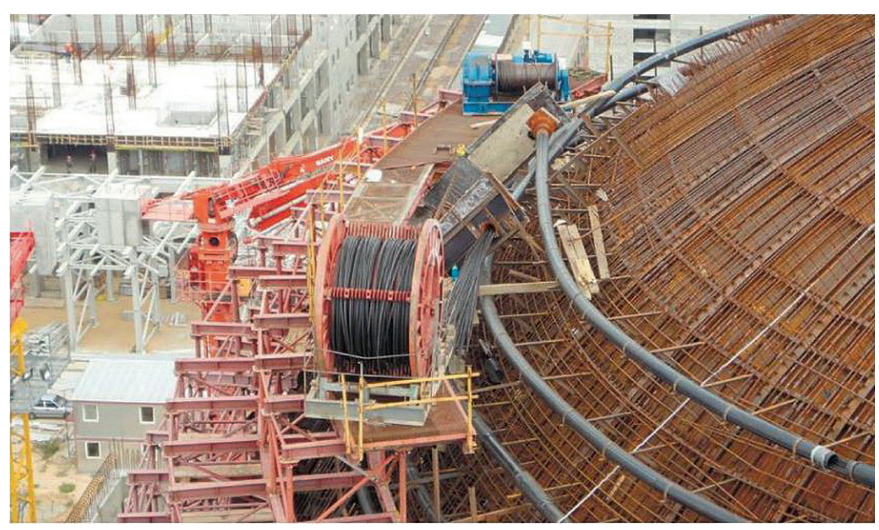

Рис. 1. Монтаж каналоутворювачів захисної оболонки реакторного відділення АЕС

(c) Т. I. Матченко, 2019 


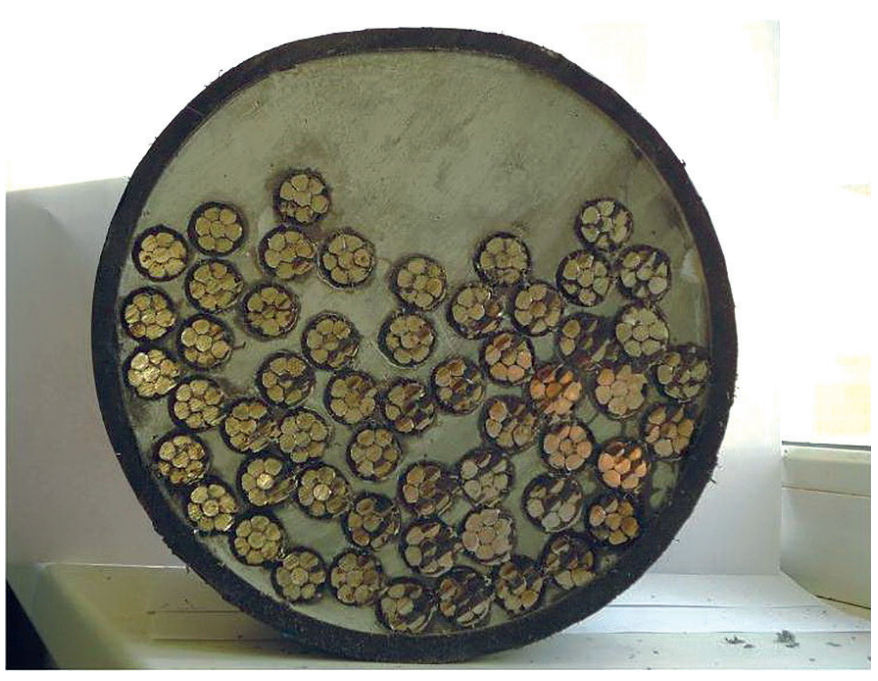

Рис. 2. Перетин каналоутворювача з армоканатами

коефіцієнта тертя АК по каналоутворювачах у часі на період роботи 30 необхідно знати їх довговічність. Довговічність полімерних матеріалів зазвичай менша за довговічність бетону і сталі. У тих випадках, коли критерієм довговічність споруди є довговічність АК, слабкою ланкою $є$ полімерні матеріали. Довговічність полімерних матеріалів є функцією значної кількості механізмів деградації. Для попередньої оцінки деградації полімерних матеріалів можна скористатися величинами швидкості деградації для лінійної моделі процесу, наведеними в [3]. Для більш точного визначення нелінійних процесів деградації полімерів на підставі експериментальних досліджень необхідні методики виконання досліджень і обробки їх результатів. Такі методики відсутні в нормативних документах з атомної енергетики та в будівельній галузі в Україні.

Мета роботи - сформулювати методику визначення довговічності полімерних матеріалів за результатами їх випробувань для механізмів: термічне старіння і радіаційне старіння для можливості іï використання при визначенні довговічності полімерних матеріалів каналоутворювачів і полімерних захисних трубок АК 3 О АЕС.

\section{Основні положення процесу визначення довговічності полімерних матеріалів за результатами випробування зразків}

Пошкодження полімерного матеріалу за будьяким параметром, що контролюється під час обстежень, визначається окремо для кожного механізму деградації. 3 деградації окремих механізмів склада- ється узагальнена деградація і сумарне пошкодження $\omega_{\mathrm{s}}$. Пошкодження вимірюється в долях від одиниці. За відсутності пошкоджень $\omega_{\mathrm{s}}=0$. У випадку, коли відбувається руйнування матеріалу полімеру, $\omega_{\mathrm{s}}=1$.

Окремі механізми деградації і відповідні їм параметри пошкодження $є$ такими: $\omega_{1}$ - температурне старіння; $\omega_{2}$ - радіаційне фотонне старіння; $\omega_{3}$ - радіаційне нейтронне старіння; $\omega_{4}$ - радіаційне ультрафіолетове старіння; $\omega_{5}-$ деформаційне старіння; $\omega_{6}$ - малоциклове термічне старіння; $\omega_{7}$ - багатоциклове термічне старіння; $\omega_{8}$ - малоциклове деформаційне старіння; $\omega_{9}$ - багатоциклове деформаційне старіння; $\omega_{10}$ корозія на поверхні; $\omega_{11}$ - абразивний знос поверхні.

Внаслідок зміни температури полімерного матеріалу змінюються його механічні властивості. Icнують такі критичні температури зміни стану полімерного матеріалу: $T_{\text {K }}$ - температура крихкості; $T_{\text {в }}$ - температура відновлення або пластичності; $T_{\text {п }}$ - температура плавлення.

1) у разі значень температури нижче $T_{K}$ - полімерний матеріал руйнується крихко; малі значення $K_{\text {IC }}$ (критичного значення коефіцієнта інтенсивності напружень для тріщини нормального відриву в матеріалі); матеріал деформується пружно; після руйнування відсутні залишкові пластичні деформації на поверхні злому; швидко відбувається процес старіння; мале значення енергії активації $\left(E_{\mathrm{a}}\right)$; поступове

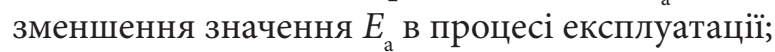

2) у разі значень температури в інтервалі від $T_{K}$ до $T_{\text {в }}$ - полімерний матеріал руйнується в'язко-крихко; коефіцієнт $K_{\text {IC }}$ набуває відносно великих значень; матеріал деформується пружно-пластично; після руйнування є залишкові пластичні деформації на поверхні злому; відносно високі значення енергії активації $E_{\mathrm{a}}$, в цьому стані $E_{\text {a }}$ - const протягом експлуатації;

3) у разі значень температури в інтервалі від $T_{\text {в }}$ до $T_{\text {п }}$ - полімерний матеріал руйнується в'язко; без утворення тріщин; матеріал деформується пластично; у разі зняття напружень заліковуються наслідки процесів старіння, які виникли під час експлуатації за низьких температур; поступово збільшуються зна-

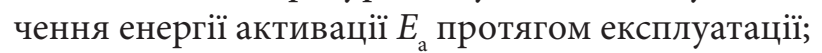

4) у разі значень температури вище $T_{\Pi}$ - полімерний матеріал з твердого стану переходить у рідкий.

Таким чином, визначення довговічності полімерного матеріалу за результатами випробувань після прискореного старіння у разі підвищених температур необхідно виконувати для температури, що не перевищує $T_{\mathrm{B}}$. Прогноз довговічності буде коректним, якщо протягом експлуатації температура по- 
лімерного матеріалу не зменшується нижче $T_{\mathrm{K}}$ i не перевищує $T_{\mathrm{B}}$.

\section{Визначення довговічності полімерних матері- алів за результатами їх випробувань після прискореного старіння від дії температури}

Температурне старіння (параметр деградації $\omega_{1}$ ) визначається залежністю

$$
\omega_{1}(T, t)=\mathrm{S}_{1}(T, t) t(T),
$$

де $t(T)$ - час дії температури $T$ на полімер, год; $S_{1}(T, t)-$ швидкість деградації (в цьому випадку швидкість старіння) полімеру внаслідок дії температури, (долі від одиниці)/год; $\omega_{1}(T, t)$ - параметр, який відображає зміну в часі параметра деградації, який контролюється (наприклад, відносне видовження зразка після розриву $A$ \%) внаслідок дії температури, долі від одиниці.

Швидкість старіння $S_{1}(T, t)$, яка виникає внаслідок дії температури, визначається законом Арреніуса

$$
S_{1}(T, t)=k \times \exp \left(-E_{\mathrm{a}} / R T\right)
$$

де $k$ - коефіцієнт пропорційності, має розмірності долі/год; $T$ - температура полімеру, ${ }^{\circ} \mathrm{K} ; ~ R$ - універсальна газова постійна Больцмана, $R=8,31$ Дж $\times \mathrm{K}^{-1}$ моль $^{-1}$; $E_{\text {a }}$ - еквівалентна енергія активації процесу старіння полімеру, Дж $\times$ моль $^{-1}$.

Отже, для визначення швидкості старіння полімеру за температури експлуатації $T$, необхідно знайти шляхом прискорених випробувань значення параметрів $E_{\text {a }}$ i , які $€$ константами матеріалу для діапазону температур експлуатації $\Delta T$, в межах яких відсутні стрибки та зломи на графіку залежності $S_{1}(T, t)-T$.

Значення контрольованого параметра (умовно позначимо цей параметр як П) на початку експлуатації $(t=0)$ і на час експлуатації $t$ визначається залежностями:

для параметра, що зменшує своє значення протягом експлуатації:

$$
\Pi_{\mathrm{e}}=\Pi_{0}(1-\omega)
$$

а для параметра, що збільшує своє значення:

$$
\Pi_{\mathrm{e}}=\Pi_{0}(1 /(1-\omega)) .
$$

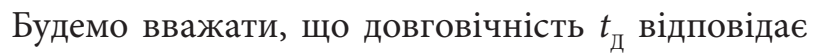
значенню критично допустимого пошкодження $\omega_{u}$.
Для полімерів $\omega_{u}=0,5$, для бетону $\omega_{u}=0,3$, для сталі $\omega_{u}=0,15$.

Рівняння (1) і (2) не змінюються залежно від значення температури полімеру. Параметри $E_{\mathrm{a}} \mathrm{i} k$ не змінюються в межах $\Delta T$. Тоді під час прискореного старіння 3 підвищеною температурою $T_{1}$, пошкодження полімеру величиною $\omega_{u}=0,5$ буде досягнуто за час $t_{1}$.

Існують такі якісні стани полімерного матеріалу, які залежать від температурного інтервалу, в якому перебуває матеріал. Зокрема у разі нормальної експлуатації за середньої температури протягом експлуатації $T_{\mathrm{e}}$ пошкодження величиною $\omega=0,5$ буде досягнуто за час $t=t_{\mathrm{e}}$ за умови, що $T_{1} \mathrm{i} T_{\mathrm{e}}$ знаходяться в межах $\Delta T$

Можна записати

$$
0,5=\omega_{1}\left(T_{1}, t_{1}\right)=\omega_{1}\left(T_{\mathrm{e}}, t_{\mathrm{e}}\right)
$$

Тоді

$$
t_{1} \times k \times \exp \left(-E_{\mathrm{a}} / R T_{1}\right)=t_{\mathrm{e}} \times k \times \exp \left(-E_{\mathrm{a}} / R T_{\mathrm{e}}\right) .
$$

Тоді $t_{\mathrm{e}}$ визначається рівнянням

$$
t_{\mathrm{e}}=t_{1} \times \exp \left(-E_{\mathrm{a}} \times\left(1 / T_{1}-1 / T_{\mathrm{e}}\right) / R\right)
$$

де $t_{\mathrm{e}}$ - довговічність полімеру при його старінні тільки внаслідок дії температури середовища, год.

Невідомими в рівнянні (7) є тільки значення еквівалентної енергії активації старіння $\left(E_{\mathrm{a}}\right)$ матеріалу, що досліджується. Значення $\left(E_{\mathrm{a}}\right)$ можна знайти за результатами двох випробувань зразків з метою визначення їх старіння $\omega_{1}$ за параметром, що контролюється, з попереднім старінням при двох значеннях температури $T$ в межах $\Delta T$. Тоді

$$
\begin{aligned}
& \omega_{1}=t_{1} \times k \times \exp \left(-E_{\mathrm{a}} / R T_{1}\right), \\
& \omega_{2}=t_{2} \times k \times \exp \left(-E_{\mathrm{a}} / R T_{2}\right),
\end{aligned}
$$

де $\omega_{1}, \omega_{2}-$ значення пошкодження полімеру за параметром, що контролюється для першого і другого випробування, долі; $T_{1}, T_{2}$ - температура при першому i другому випробуванні, ${ }^{\circ} \mathrm{K} ; t_{1}, t_{2}$ - час першого і другого випробування, год.

Тоді

$$
E_{\mathrm{a}}=\lg \left[\left(\omega_{2} \times t_{1}\right) \mid\left(\omega_{1} \times t_{2}\right) /\left[1 / T_{1}-1 / T_{2}\right) / R\right] \text {. }
$$


Якщо далі необхідно знайти значення коефіці$є н т а$ пропорційності, то його можна визначити за формулою

$$
k=t_{i} \times \exp \left(-E_{\mathrm{a}} / R T_{i}\right) / \omega_{i}
$$

де $t_{i}, T_{i}, \omega_{i}-$ значення параметрів для випробування з індексом $(i)$.

Аналіз випробувань показує спочатку поступове збільшення, а потім зменшення міцності на розрив полімерного матеріалу внаслідок старіння; спочатку зростання, а потім зменшення видовження зразка після розриву; спочатку збільшення, а потім зменшення площі діаграми деформування.

\section{Визначення швидкості зростання енергії активації полімеру за результатами випробувань при $T>T_{\text {в }}$}

Енергія активації полімеру не змінюється для другого якісного стану в інтервалі температур $T_{\mathrm{K}}-T_{\mathrm{B}}$ i $\epsilon$ константою $E_{\mathrm{a} 2}$ - const. Якщо полімер знаходиться $t$ діб при температурі $T>T_{\text {в в третьому }}$ якісному стані, то його енергія активації визначається за формулою

$$
E_{\mathrm{a} 3}=E_{\mathrm{a} 2}+v_{\mathrm{ET} 3} \times\left(T_{\mathrm{B}}-T\right) \times t
$$

де $v_{\text {Етз }}$ - швидкість зростання енергії активації при дії температури, Дж $\times \mathrm{K}^{-1}$ моль $^{-1}$ ді6 $^{-1} ; t$ - тривалість дії температури $T>T_{\mathrm{B}}$, діб; $T_{\mathrm{B}}$ - температура відновлення або пружно пластичного переходу. Зазвичай $T_{\text {в }}$ знаходиться в діапазоні $(0,6-0,8) \times T_{\Pi} ; T_{\Pi}$ - температура плавлення полімеру, ${ }^{\circ} \mathrm{K}$.

Швидкість зростання енергії активації визначається за формулою

$$
v_{\mathrm{ET} 3}=\left(E_{\mathrm{a} 3}-E_{\mathrm{a} 2}\right) /\left(t \times\left(T_{\mathrm{B}}-T\right)\right) .
$$

Значення $E_{\text {аз }}$ i $E_{\text {а2 }}$ визначаються за формулою (10) за результатами випробувань зразків після нагріву при $T>T_{\mathrm{B}}$ і $T<T_{\mathrm{B}}$.

\section{Визначення швидкості зменшення енергії активації полімеру за результатами випробувань при $T<T_{\text {к }}$}

Якщо полімер знаходиться $t$ діб при температурі $T<T_{\text {K }}$ у першому якісному стані, то його енергія активації визначається за формулою

$$
E_{\mathrm{a} 1}=E_{\mathrm{a} 2}+\mathrm{v}_{E T 1} \times\left(T_{\mathrm{K}}-T\right) \times t,
$$

де $v_{E T 1}$ - швидкість зменшення енергії активації при дії температури, Дж $\times \mathrm{K}^{-1}$ моль $^{-1}$ дi $^{-1} ; T_{\mathrm{K}}$ - температура крихкості або склування полімеру, ${ }^{\circ} \mathrm{K}$.

Швидкість зменшення енергії активації визначається за формулою

$$
v_{\mathrm{ET} 1}=\left(E_{\mathrm{a} 2}-E_{\mathrm{a} 1}\right) /\left(t \times\left(T_{\mathrm{K}}-T\right)\right) .
$$

Значення $E_{\mathrm{a} 1}$ i $E_{\text {а2 }}$ визначаються за формулою (10) за результатами випробувань зразків після нагріву

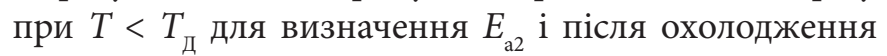
при $T<T_{\mathrm{K}}$ при визначенні $E_{\mathrm{a} 1}$.

\section{Визначення довговічності полімерних матеріалів за результатами їх випробувань після прискореного старіння від дії ультрафіо- летового опромінення}

Полімерні матеріали будівельних конструкцій, що експлуатуються без захисту від сонячного (ультрафіолетового) опромінення, накопичують енергію, яка впливає на структурні зміни і хімічні процеси полімеру. Внаслідок цього відбувається радіаційне ультрафіолетове старіння $\omega_{4}$ полімеру. Потужність накопичення енергії радіаційного опромінення полімеру за один місяць опромінення визначається за формулою

$$
Q_{\mathrm{M}}=Q_{\mathrm{C}} \times k_{n}
$$

де $Q_{\mathrm{C}}$ - середньомісячне значення потужності енергії радіації на горизонтальній поверхні, Вт/(м²× місяць), за [1]; $k_{n}$ - коефіцієнт поглинання енергії матеріалу, долі від одиниці; $Q_{\mathrm{M}}$ - середньомісячне значення сумарної потужності енергії радіації, накопиченої матеріалом, Вт/( $\mathrm{m}^{2} \times$ місяць $)$.

Можна записати $q_{\mathrm{C}}=Q_{\mathrm{C}} / 730,5$, де $q_{\mathrm{C}}$ - середньомісячне значення сумарної потужності енергії радіації, що накопичується матеріалом за одну годину, Вт/(м²× год); 730,5 - кількість годин в одному місяці. Тоді

$$
\omega_{4}\left(q_{\mathrm{C}}, t\right)=S_{\mathrm{C}}(q, t) \times t(q),
$$

де $t(q)$ - час дії ультрафіолетового опромінення, год; $S_{\mathrm{C}}(q, t)$ - швидкість деградації полімеру внаслідок дії ультрафіолетового опромінення, долі/год; $\omega_{4}\left(q_{\mathrm{C}}, t\right)$ - параметр пошкодження, який відображає зміну в часі 
параметрів, які контролюються (наприклад, відносне видовження зразка після його розриву, теплопровідність тощо). Тоді

$$
\omega_{4}\left(q_{\mathrm{C}}, t\right)=A\left(q, t=t_{\mathrm{on}}\right) / A(q, t=0)
$$

де $t_{\text {оп }}$ - тривалість опромінення, год; $t=0$ - час на початку опромінення, год.

Швидкість старіння $S_{\mathrm{C}}(q, t)$ зумовлена дією ультрафіолетового опромінення, визначається залежністю

$$
S_{\mathrm{C}}(q, t)=Z_{1} \times \exp \left(-Z_{2} \times q\right)
$$

де $Z_{1}$ - коефіцієнт, який не має розмірності; $Z_{2}-$ коефіцієнт, $\mathrm{M}^{2} \times$ год/Вт.

Значення коефіцієнтів $Z_{1}$ i $Z_{2} є$ константами матеріалу полімеру, і вони можуть бути визначені за результатами двох серій випробувань. Якщо для першої серії випробувань середня швидкість старіння становить $S_{\mathrm{C}}(q, t)=S_{1}\left(q_{1}, t\right)$ за середній час випробування $t=t_{1}$ при середній потужності опромінення $q=q_{1}$, тоді буде досягнуто значення параметру старіння $\omega=\omega_{\mathrm{u}}=\omega_{1}$, а для другої серії випробування при $S_{\mathrm{C}}(q, t)=S_{2}\left(q_{2}, t\right), t=t_{2}, q=q_{2}$ буде досягнуто значення параметру старіння $\omega=\omega_{u}=\omega_{2}$, то можна записати

$$
\begin{gathered}
\omega_{u}=\omega_{1}=\omega_{2}, \\
S_{1}\left(q_{1}, t\right) \times t_{1}=S_{2}\left(q_{2}, t\right) \times t_{2}, \\
Z_{1} \times \exp \left(-Z_{2} \times q_{1}\right) \times t_{1}=Z_{2} \times \exp \left(-Z_{2} \times q_{2}\right) \\
\times t_{2} .
\end{gathered}
$$

Тоді

$$
Z_{2}=\lg \left[t_{1} / t_{2}\right] /\left(q_{1}-q_{2}\right)
$$

за умови, що $\omega_{1}=\omega_{2}$, після того як визначили $Z_{2}$, знайдемо значення $Z_{1}$ за формулою

$$
Z_{1}=\omega_{1} / \exp \left(-Z_{2} \times q_{1}\right)
$$

або

$$
Z_{1}=\omega_{1} / \exp \left(-Z_{2} \times q_{1}\right)
$$

Довговічність полімеру $t_{\mathrm{e}}$, що експлуатується під дією ультрафіолетового опромінення, визначається за формулами

$$
\begin{gathered}
t_{e}=\omega_{u} / S_{\mathrm{C}}(q, t)=\omega_{u} /\left(Z_{1} \times \exp \left(-Z_{2} \times q_{e}\right)\right), \\
t_{e}=t_{1} \times \exp \left(Z_{2} \times\left(q_{e}-q_{1}\right)\right),
\end{gathered}
$$

де $q_{\mathrm{e}}$ - середня потужність опромінення протягом експлуатації; $q_{1}$ - потужність опромінення під час випробування, Вт/ $\left(\mathrm{M}^{2} \times\right.$ год) ; $t_{1}$ - тривалість опромінення під час випробування, год.

Довговічність полімеру $t_{e}$, що експлуатується в умовах одночасної дії температури та ультрафіолетового опромінення, визначається залежністю

$$
t_{e}=\omega_{u} /\left(S_{\mathrm{T}}\left(T_{\mathrm{e}}, t\right)+S_{\mathrm{C}}\left(q_{\mathrm{e}}, t\right)\right)
$$

де $S_{\mathrm{T}}\left(T_{\mathrm{e}}, t\right)$ - середня швидкість старіння полімеру за середньої температури експлуатації $T_{\mathrm{e}}, S_{\mathrm{C}}\left(q_{\mathrm{e}}, t\right)-$ ceредня швидкість старіння полімеру за середньої потужності ультрафіолетового опромінення $q_{\mathrm{e}}$ протягом експлуатації.

\section{Визначення зсуву критичної температури крихкості полімерного матеріалу внаслідок термічного старіння}

Зсув критичної температури крихкості внаслідок термічного старіння визначається за формулою

$$
\Delta T_{\mathrm{T}}=T_{\mathrm{KT}}-T_{\mathrm{K} 0}
$$

де $\Delta T_{\mathrm{T}}$ - величина зсуву температури, ${ }^{\circ} \mathrm{K} ; T_{\mathrm{KT}}-$ критична температура крихкості матеріалу, який піддається термічному старінню, ${ }^{\circ} \mathrm{K} ; T_{\mathrm{K} 0}$ - критична температура крихкості матеріалу на початку експлуатації (до відліку старіння).

Під критичною температурою крихкості розуміється температура, яка відповідає температурному кордону зміни характеру руйнування полімеру від крихкого до в'язкого. Ця температура визначається за енергією, яка витрачається на руйнування. Показником, який контролюється, є ударна в'язкість матеріалу [2]. За виглядом злому зразка, показником крихкого або в'язкого руйнування приймається відношення площі в'язкої складової в зломі відносно загальної площі злому або значення поперечного розширення зразка в зоні злому.

Для визначення критичної температури крихкості полімеру здійснюють випробування зразка з надрізом типу V на ударний згин у визначеному інтервалі температур. На підставі отриманих результатів 
випробувань будують залежність ударної в'язкості, в'язкої складової в зломі і поперечного розширення зразка залежно від температури випробувань. За заданими критичними значеннями ударної в'язкості і в'язкої складової в зломі з використанням графіків їх залежності від температури, визначають значення критичної температури крихкості полімеру.

Термічного старіння зазнають заготовки під зразки розміром $60 \times 13 \times 13$ мм. Температуру термічного старіння задають відповідно до нормативно-технічної документації на виріб або матеріал, і вона не повинна бути меншою за розрахункову температуру $T_{\mathrm{K}}+30^{\circ} \mathrm{C}$ або перевищувати іiі більше ніж $T_{\text {в }}-30^{\circ} \mathrm{C}$. У процесі витримки зразка за температури старіння допускається коливання температури в межах $\pm 5^{\circ} \mathrm{C}$ від номінального значення температури старіння.

Заготовки зразків для випробувань на ударний згин витримуються за заданої температури протягом 500, 1000, 3000, 5000, 7500, 10000 год. Для полімерів, які не мають екстремума зміни $T_{\text {кт }}$ у процесі старіння за витримки від 5000 до 10000 год, випробування з тривалістю витримки 7500 год допускається не виконувати. У випадку, якщо залежність $T_{\text {кт }}$ від часу старіння має монотонну залежність, що прагнуче до насиченості, експериментальні данні $\Delta T_{\mathrm{T}}=T_{\mathrm{KT}}-T_{\mathrm{K} 0}$ для різних тривалостей старіння апроксимуються рівнянням

$$
\Delta T_{\mathrm{T}}=\Delta T_{\mathrm{T}}^{\lim }\left(1-e^{-p t}\right)
$$

де $\Delta T_{\mathrm{T}}^{\lim }, p$ - емпіричні постійні, які визначаються за допомогою методів математичної статистики; $t$ - тривалість старіння, год.

У випадку екстремального характеру залежності $T_{\text {Кт }}$ від тривалості старіння в перелічених інтервалах часу використовується апроксимація «спадаючої» ділянки залежності за рівнянням

$$
\Delta T_{\mathrm{T}}=\Delta T_{\mathrm{T}}^{\max } \times\left(1-e^{-b \cdot\left(t-t_{\max }\right)}\right)+C
$$

де $\Delta T_{\mathrm{T}}^{\max }$ - зсув критичної температури крихкості матеріалу в околиці екстремума; $t_{\max }$ - тривалість старіння, при якому спостерігається екстремум (максимум); $b$ та $C$ - емпіричні постійні, які визначаються за допомогою методів математичної статистики, ${ }^{\circ} \mathrm{C}$.

Якщо за температури й тривалості старіння, що перевищують перелічені вище показники, відбувається монотонне зменшення $T_{\text {кт }}$, яке не прагне до насиченості, допускається встановлювати залежність
$T_{\mathrm{KT}}$ від часу старіння з використанням параметра Холломона за формулою

$$
T_{\mathrm{KT}}=H_{p}=(T+273) \times(M+\lg (t)) \times 10^{-3},
$$

де $t$ - тривалість старіння, год; $T$ - температура старіння, ${ }^{\circ} \mathrm{C} ; M$ - емпірична постійна, яка визначається методом математичної статистики.

При цьому температура старіння повинна перевищувати встановлену на $50{ }^{\circ} \mathrm{C}$, а тривалість старіння становити 1000, 3000, 5000 год. Вказана в цьому випадку методика може застосовуватися у випадку однакового характеру зміни залежності $T_{\mathrm{KT}}-T$ за використаних температур старіння.

\section{Проведення випробування зразків}

Розміри зразка для випробування на ударну в’язкість показано на рис. 3. Розташування зразка для випробування ударом маятника відображено на рис. 4. Розташування зразка для випробування ударом методом Шарпі показано на рис. 5. Температурний інтервал випробування на ударну в'язкість зразків повинен бути таким, що би в нього обов'язково входила точка $T_{\mathrm{K}}$; $T_{\mathrm{K}} \pm 10^{\circ} \mathrm{C} ; T_{\mathrm{K}} \pm 20^{\circ} \mathrm{C} ; T_{\mathrm{K}} \pm 30^{\circ} \mathrm{C} ; T_{\mathrm{K}} \pm 40{ }^{\circ} \mathrm{C}$. Для кожної температури випробування повинно бути не менше трьох зразків. Якщо орієнтовне значення $T_{\mathrm{K} 1}$ заздалегідь невідоме, допускається виконувати випробування в ін-

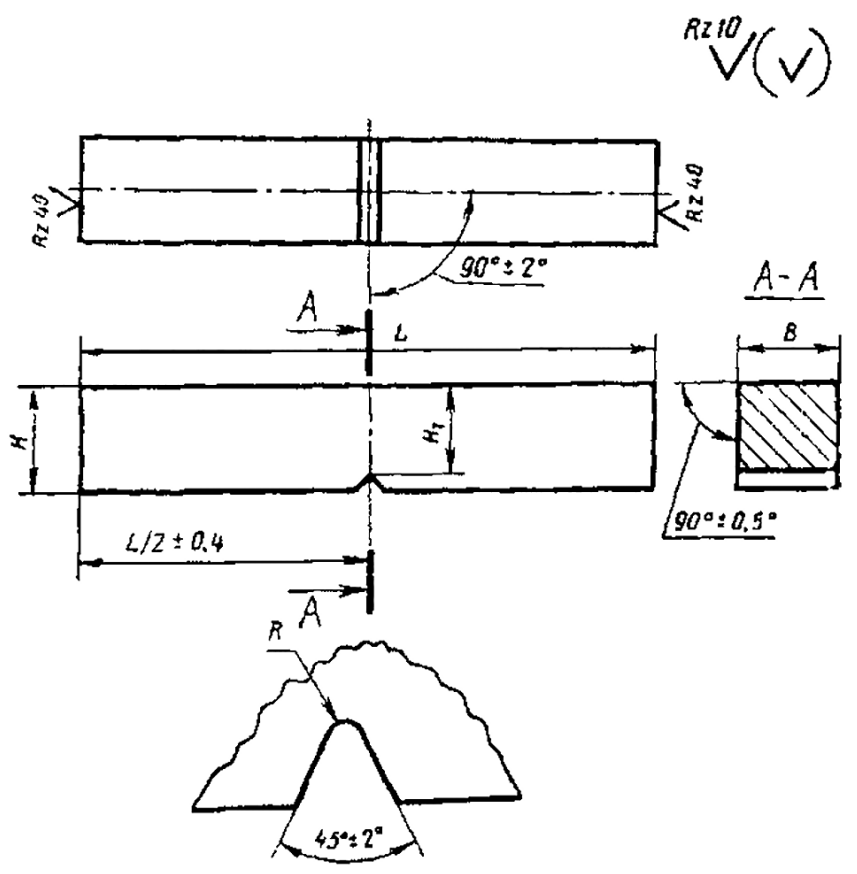

Рис. 3. Зразок для випробування на ударну в'язкість полімерних матеріалів: $\mathrm{B}=3$ мм; $\mathrm{H}=10$ мм 


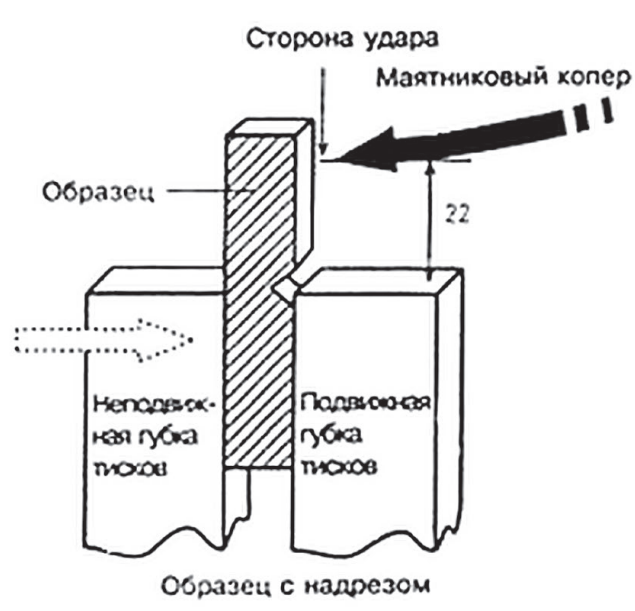

a

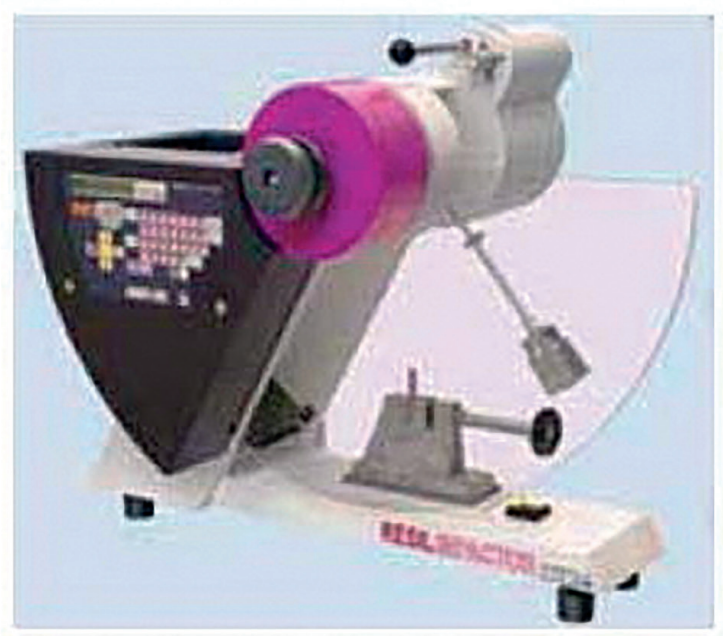

6

Рис. 4. Випробування зразка на ударну в’язкість ударом маятника: а - метод вимірювання ударної міцності за Ізодом; 6 - маятниковий копер для вимірювання ударної міцності за Ізодом, фірма CEAST
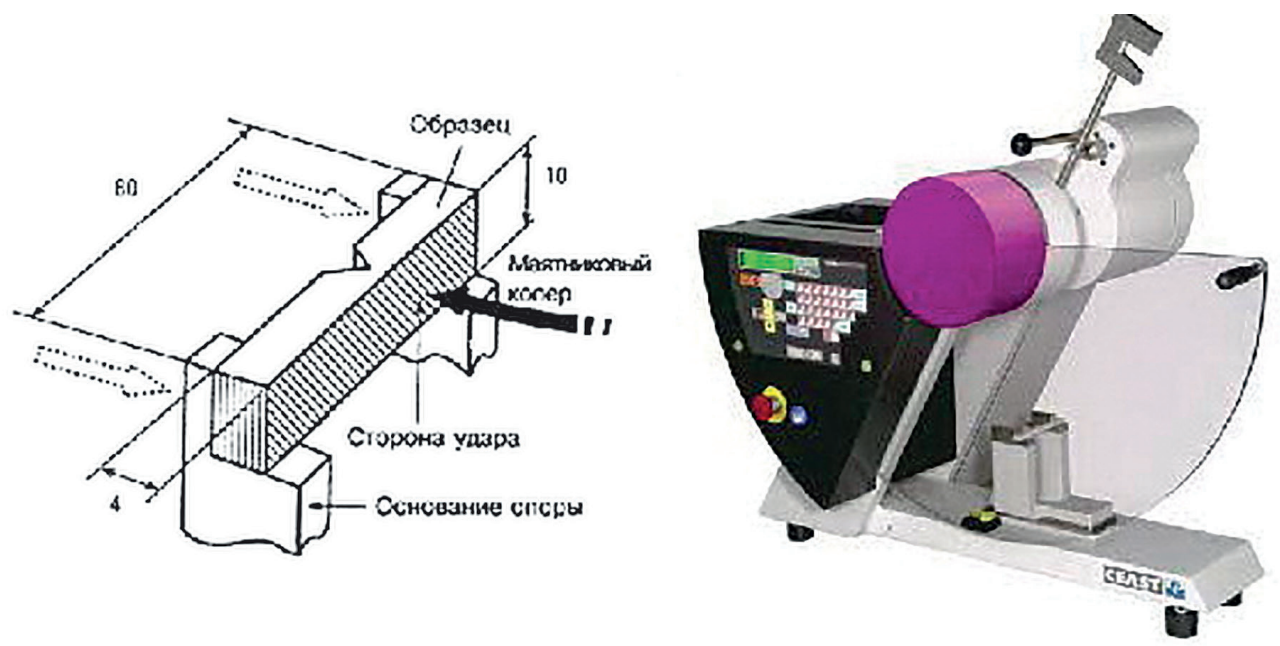

Рис. 5. Випробування зразка на ударну в'язкість методом Шарпі

тервалі температур $\left(T_{\mathrm{K} 1}-10^{\circ} \mathrm{C}\right)<T<\left(T_{\mathrm{K} 1}+40^{\circ} \mathrm{C}\right)$.

У випадку, коли орієнтовне значення $T_{\mathrm{K} 1}$ заздалегідь невідоме, рекомендується визначати значення ударної в’язкості за двох значень температур $20^{\circ} \mathrm{C} \mathrm{i} 0^{\circ} \mathrm{C}$. Далі порівнюють ці значення (які повинні бути не нижче) з критичними значеннями $K C V_{\mathrm{K}}$ визначеними за формулою

$$
K C V_{\mathrm{K}}=R_{p 0,2} \times A \times k_{V} \times b_{1} /\left(\gamma_{\mathrm{C}} \times k_{\mathrm{np}}\right)
$$

де $R_{p 0,2}$ - межа текучості матеріалу за температури $T=20{ }^{\circ} \mathrm{C}$, Па; $A$ - відносне подовження зразка після його розриву, долі; $k_{V}$ - коефіцієнт, який враховує виточку у формі $V$ і дорівнює $k_{V}=10^{-2}$, долі; $b_{1}-$ коефіцієнт, який дорівнює $1 \mathrm{~m} ; \gamma_{\mathrm{C}}-$ коефіцієнт надій- ності, який дорівнює 1,$2 ; k_{\text {пр }}$ - коефіцієнт переходу вимірювань $K C V$ із Дж/ ${ }^{2}$ на Дж/ $\mathrm{cm}^{2}$ і який дорівнює $k_{\text {пр }}=10^{4} \mathrm{~cm} / \mathrm{M}$.

Визначають інтервал подальших температурних випробувань, виходячи з рівняння

$$
\begin{aligned}
K C V & =a+b_{2} \times \exp (c \times T), \\
K C V_{\mathrm{K}} & =a+b_{2} \times \exp \left(c \times T_{\mathrm{K}}\right) .
\end{aligned}
$$

Тоді

$$
\frac{K C V-a}{K C V_{\mathrm{K}}-a}=\exp \left(\mathrm{c} \times\left(\mathrm{T}-T_{\mathrm{K}}\right)\right)
$$


Далі

$$
T_{\mathrm{K}}=T-\lg \left(\frac{K C V-a}{K C V_{\mathrm{K}}-a}\right) / c
$$

де (c) має розмірність $1 /{ }^{\circ} \mathrm{C}$; ( $a$ i $b_{2}$ ) має розмірність, Дж/м². Рівняння (37) має дві невідомі $T_{K}$ i (c). Маючи результати двох випробувань $K C V_{20}$ i $K C V_{0}$ за температур $20^{\circ} \mathrm{C}$ i $0{ }^{\circ} \mathrm{C}$, можна визначити $T_{\mathrm{K} 1}$ у першому приближенні.

У випадку, коли немає можливості провести випробування на ударну в'язкість полімерних матеріалів, значення $T_{\mathrm{K}}$ можна визначити за результатами випробувань зразків на одноосний розрив. У такому випадку $T_{\mathrm{K}}$ визначається за діаграмою зміни залежності відносного видовження зразка після його розриву $(A)$ від температури $(T)$. Значення $T_{\mathrm{K}}$ відповідає злому або стрибку на діаграмі $A-T$. Загальний вигляд універсальної випробувальної машини на розрив зразка показано на рис. 7. Загальний вигляд зразка для випробування на одновісний розрив показаний на рис. 7a, а випробування із застосуванням екстензометра «Пласт» фірми Galdabini - на рис. 76.

\section{Висновки}

1. Викладено процедури визначення довговічності полімерних матеріалів, які старіють унаслідок дії температури та радіаційного опромінення, за результатами їх випробувань на ударну в’язкість та осьове розтягнення.

2. Отримані результати можуть бути використані для визначення реологічних змін полімерних матеріалів, коефіцієнтів тертя арматури по каналу, довговічності полімерних каналів та полімерних захисних трубок АК та інших полімерів, які використовуються в $3 О$ реакторних відділень АЕС.

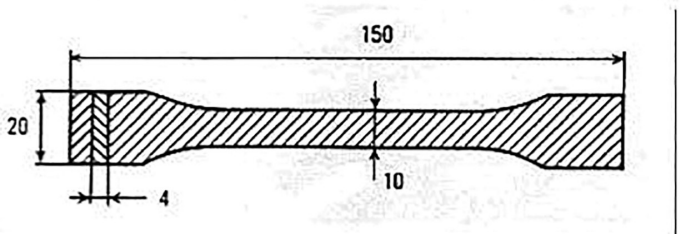

Рис. 6. Універсальний зразок для випробування полімерного матеріалу на одновісне розтягнення відповідно до ISO/R 527:1966, ГОСТ 11262-80 (тип 2); розміри зразка вказані в мм
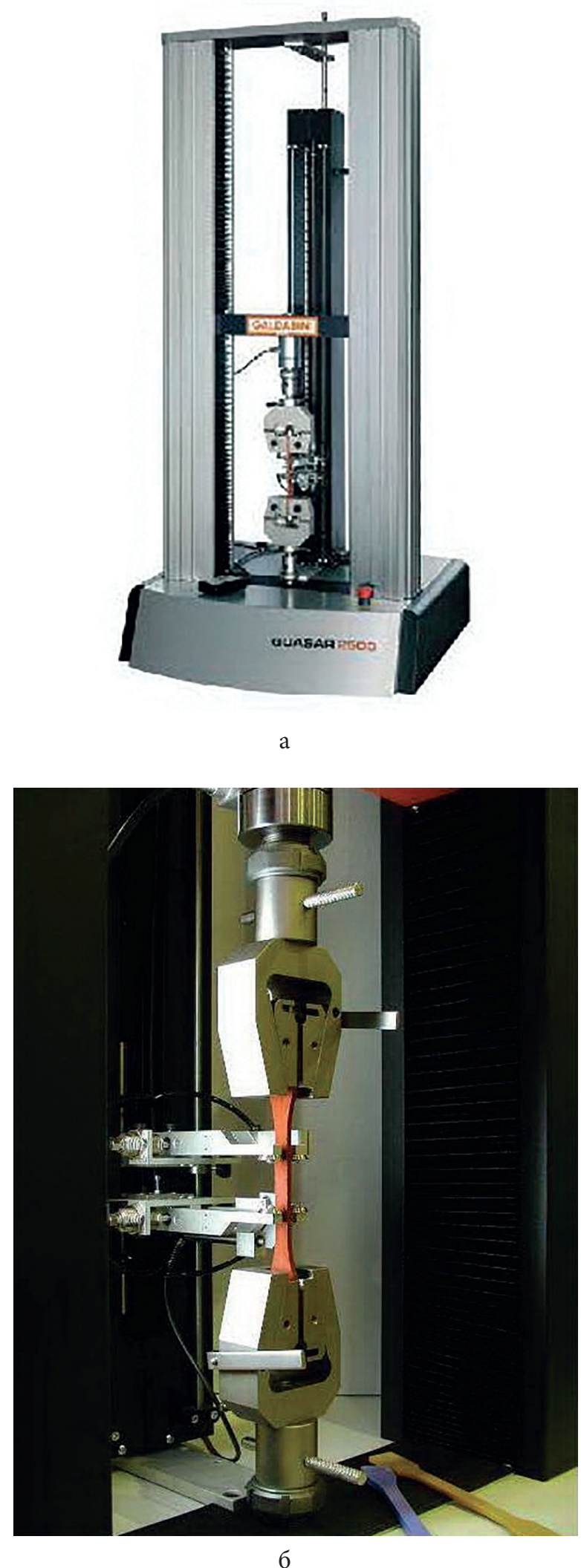

Рис. 7. Універсальна випробувальна машина для проведення механічних випробувань фірми Galdabini; a - загальний вигляд; 6 - випробування із застосуванням екстензометра «Пласт» фірми Galdabini 


\section{Список використаної літератури}

1. ДСТУ-Н Б В.1.1-27:2010. Будівельна кліматологія. Захист від небезпечних геологічних процесів, шкідливих експлуатаційних впливів, від пожежі. [Прийнятий Наказом Мінрегіону України від 16.12.2010 р. № 511, чинний від 01.11.2011р.] / Мінрегіонбуд України. Київ : Укрархбудінформ, 2011. - 123 с.

2. ПНАЭ Г-7-002-86. Нормы расчета на прочность оборудования и трубопроводов атомных энергетических установок [Введены с изменениями 01.07.1987 г.] / Госатомэнергонадзор СССР. - М. : Энергоатомиздат, 1989. - 525 c.

3. Матченко Т. І. Методика оцінки ресурсу ущільнювачів і герметиків будівельних конструкцій / Т. І. Матченко, Л. Б. Шаміс, П. Т. Матченко, Л. Ф. Первушова // Проблеми безпеки атомних електростанцій i Чорнобиля. - 2011. - Вип. 15.- С. 72-84.

4. Выполнение расчетного обоснования надежности СГО ЛСБ энергоблока № 4 на соответствие требованиям действующих НД по определению допустимых усилий натяжения арматурных канатов СПЗО : отчет о НИР (этап 1, ред. 3) / КИЭП. - 181712.218.001РК00 ; Инв № 518-P/1-518/3.

5. Выполнение расчетного обоснования надежности СГО ЛСБ энергоблока № 4 на соответствие требованиям действующих НД по определению допустимых усилий натяжения арматурных канатов СПЗО : отчет о НИР (этап 2, ред. 1) / КИЭП. - 181712.218.002РК00 ; Инв № 522-Р. - Киев, 2018.

\section{Т. И. Матченко}

АО «Киевский научно-исследовательский и проектноконструкторский институт "Энергопроект"», nросп. Победьь, 4, г. Киев, 01135, Украина

\section{Определение реологических изменений полимерных каналов арматурных канатов}

В процессе работы канаты трутся по стенкам каналов защитной оболочки реакторного отделения атомной электростанции. Со временем разрушаются полимерные каналообразователи и защитные трубки арматурных канатов. Для определения коэффициента трения во времени арматурных канатов по каналообразователям в течение работы защитной оболочки необходимо знать долговечность полимерных материалов каналообразователей и полимерных трубок арматурных канатов. Для точного определения нелинейных процессов деградации полимеров на основе экспериментальных исследований необходимы методики выполнения исследований, обработки их результатов. Такие методики отсутствуют в нормативных документах атомной энергетики и в строительной отрасли в Украине. В статье предложена методика определения долговечности полимерных материалов после их ускоренного старения по результатам испытания образцов на одноосное растяжение и разрушение.

Ключевые слова: арматурные канаты, полимерные материалы, реологические изменения, долговечность, каналообразователи.

\section{T. I. Matchenko}

JSC "Kyiv Research and Design Institute 'Energoproject", 4, Peremogy av., Kyiv, 01135, Ukraine

\section{Determination of Relogic Changes of Polymeric Channels of Armature Hands}

The containment of the reactor compartment should ensure the integrity of the interior at the time of the accident. For compression containment tensioning ropes are used. Ropes rub against the wall of the holes in the shell. Due to the tension of the ropes the crack opening is prevented. Over time, polymer protective sheaths of ropes are destroyed. In the wire ropes there are abrasive cracks. It is necessary to know the durability of the polymeric materials of the channel formers and the tubes of the reinforcement ropes to determine the coefficient of friction of reinforcing ropes along the channel formers in time during the operation of the containment. To accurately determine the nonlinear processes of polymer degradation on the basis of experimental studies, a technique is needed for carrying out the testing of polymer samples, processing the results of the studies. Such methods are not available in the regulatory documents of nuclear energy and the construction industry in Ukraine. In the article:

the main provisions of the process of determining the durability of polymer materials based on the results of testing the samples are described;

the procedure of determining the durability of polymeric materials according to their tests after accelerated aging from the temperature action is described;

the procedure of determination of the growth rate of activation energy of a polymer based on the results of tests at $T>T_{\mathrm{V}}$ is stated; 
the procedure of determination of the reduction rate of activation energy of a polymer according to the results of tests at $T<T_{\mathrm{K}}$ is stated;

the procedure of determination of durability of polymeric materials on the results of their tests after accelerated aging from the effect of ultraviolet irradiation is described;

the procedure of determination of the shift of the critical temperature of the fragility of the polymeric material due to thermal aging is described;

the procedure of determination of the durability of polymeric materials aging due to temperature and irradiation based on the results of their tests on impact strength is described;

the procedure of the determination of the durability of polymeric materials aging due to temperature and irradiation based on the results of their axial stretching tests is described.

The obtained results can be used in the determination of rheological changes of polymer materials, coefficients of friction of reinforcement along the channel, durability of polymeric channels and polymeric protective tubes of reinforcing ropes, and other polymers used in protective casings of reactor units of the NPP.

Keywords: reinforcement ropes, polymeric materials, durability, channel formers.

\section{References}

1. DSTU-N B V.1.1-27:2010 Construction climatology. Protection from hazardous geological processes, harmful operational impacts, from fire. Kyiv: Ministry for Regional Development, Building and Housing of Ukraine, 2011, 123 p. (in Ukr.)

2. USSR State Committee for the Supervision of Safe Work in the Nuclear Power Industry (1989). PNAE G-7-002-86. Norms for calculating the strength of equipment and pipelines of nuclear power plants. Moscow: Energoatomizdat, 525 p. (in Russ.)

3. Matchenko T. I., Shamis L. B., Matchenko P. T., Pervushova L. F. (2011). [Methods of assessing the resource and gasket building structures]. Problemy bezpeky atomnyh elektrostantsiy $i$ Chornobylya [Problems of nuclear power plants safety and of Chornobyl], vol. 15, pp. 72-84. (in Ukr.)

4. Research effort report "Implementation of the design justification of the reliability of sealed enclosure system - safety localization system of the power unit no. 4 for compliance with the requirements of the existing regulatory documents (to determine the allowable tension forces of reinforcing ropes containment preloading system)". Stage 1, rev. 3, 181712.218.001PK00, inv. no 518-P/1-518/3. Kyiv Research and Design Institute "Energoproject". (in Russ.)

5. Research effort report "Implementation of the design justification of the reliability of sealed enclosure system - safety localization system of the power unit no. 4 for compliance with the requirements of the existing regulatory documents (to determine the allowable tension forces of reinforcing ropes containment preloading system )". Stage 1, rev. 3, 181712.218.002PK00, inv. no 522-P. Kyiv Research and Design Institute “Energoproject”. (in Russ.)

Надійшла 24.01.2019

Received 24.01.2019 


\section{Theoretical and Practical Aspects of Using Scaling Factor Method to Characterize Operational Solid Radioactive Waste Producible at Nuclear Power Plants}

Keywords:

nuclear power plants, radioactive waste, characterization, scaling factors, key nuclides, difficult to measure radionuclide, correlation factor.

\begin{abstract}
Brief review of the most well-known analytical and methodological materials devoted to the theory and practice in characterization of radioactive waste (RAW) generated at NPPs is presented. The basic principles of method for building scaling factors (SF) and the main features of SF application in technological chain of RAW management are disclosed. It was demonstrated that the basis that allows using the SF methodology is the availability of functional relationships between the activities of various radionuclides, which are simultaneously accumulated during reactor campaign and contamination of various materials. In the course of special investigation, it is needed as follows: to take a representative sample of waste from each stream of materials subject to radiation monitoring; in the laboratory to determine the content of all radionuclides to be certified; when using the methods of statistical data analysis, to identify the key nuclides $(\mathrm{KN})$ and calculate the SF average values, which make it possible, based on the results of gamma-spectrometry of KN content, to estimate alpha and beta-emitting radionuclide activities in RAW packages, whose measurement demands high material costs and time (for DTM - difficult to measure radionuclides). An illustration of impact of different factors and mechanisms, which form DTM nuclides and KN content ratio in solid waste characteristic of RBMK-type reactors, is delivered. The basic requirements and procedures, which are to be reflected in the method to characterize solid RAW from Chornobyl NPP for DTM radionuclides certification using the SF, are determined.
\end{abstract}

\section{Introduction}

Radioactive waste (RAW) is produced from a range of activities resulting in waste streams varying by its form, activity, physical state, etc. The RAW sources are often called as "point of origin" [1], which also contain each nuclear power plant (NPP). During the normal operation of reactor installations or during a NPP decommissioning, a large amount of RAW is generated [2]. Appropriate monitoring of chemical and radiochemical parameters of RAW within the entire life cycle of waste management, and careful testing of the quality of final waste forms and waste packages, are the principal components of any waste management strategy [3]. A failure in monitoring proce- dures at any of its steps can cause important consequences, not only in follow-up steps, but, in some cases it brings to generation of waste packages, which are not compliant with the waste acceptance criteria for long-term storage or burial. The characterization of RAW includes establishing a list of radionuclides, together with their specific activity, inside each package $[3,4]$. The evaluation of radionuclide activities in radwaste is required for its disposal in final repositories. The inventory of radionuclides to be declared with each waste form is numerous and diversified (alpha- and/or beta-emitters). Some of these radionuclides are easy to measure (ETM) with using NDA (non-destructive assay) or DA (destructive assay), but most of them are difficult to measure (DTM) and need

(C) O. V. Mykhailov, V. O. Krasnov, V. M. Bezmylov, 2019 
DA in a laboratory or a calculation with using special codes (e.g. pure beta-emitters). Some of them are impossible to measure (ITM) even in a laboratory. However, it is not true for the other techniques for waste characterization, namely, NDE (non-destructive evaluation), NDA or DA. The technology available today for NDE and NDA is reliable, but costly.

To solve the existing problem, numerous studies were conducted, which allowed establishing quantitative relationships between the activities of ETM and DTM radionuclides in other RAW streams [5]. In subsequent years, the results were confirmed by more detailed studies and made the basis of scaling factor (SF) methodology [6-9].

Similar difficulties hamper full and large-scale characterization of RAW accumulated in large quantities within the territory of Chornobyl NPP (ChNPP) Exclusion Zone. In addition, beside various RAW formed as a result of mitigation of ChNPP Unit 4 accident in 1986 and located in temporary repositories and at ChNPP Shelter object, other RAW sources also exist in the Exclusion Zone: producible under decommissioning work, sites for interim storage of RAW, works related to decontamination of equipment and materials $[2,10]$.

To characterize operational solid RAW of ChNPP origin, introduction of SF methodology (SFM) in Waste Characterization Systems was recommended $[11,12]$. This approach also reflects the policies of IAEA and WANO to extend possible application of SFM to characterize the RAW producible during decommissioning of nuclear facilities and problematic/ legacy wastes, which are to be retrieved from existing storage structures.

The aim of this work is to study SFM basic principles and those used in characterization of different RAW generated in a reactor installation, and also to highlight the main requirements and procedures, which are prescribed in Technique of SF identification to characterize solid RAW accumulated over normal operation period of ChNPP Units.

\section{Basic principles and international standards used in the field of scaling factor methodology}

The disposal of RAW requires the knowledge of its radioactivity content in terms of specific radionuclide concentrations. This information is used by a repository operator and/or regulator to trace radionuclide inventories and concentrations, which are generally limited by repository safety assessment and operating licence [6].
Many of important long-lived radionuclides contained in the RAW are DTM from outside a waste package with using non-destructive techniques because they are of low energy, and non-penetrated by beta or alpha emitting nuclides (i.e. non-gamma emitters). Identification of these DTM nuclides requires the creation of methods, which, in general, involve analysis of waste samples with using complex chemical analyses to separate various radionuclides for measurement. This method is not practical for large amount of waste packages.

Several theoretical techniques for nuclide determination, such as modelling of activation in structural components of reactor core and prediction of fuel nuclide composition in nuclear fuel with using the codes, such as MCNP or SCALE, can be applied [6, 8]. However, it is difficult to predict the nuclide content in very low level-, low- and intermediate-level RAW by purely theoretical methods due to physical and chemical processes involved in RAW generation. Therefore, for such situations it is recommended to implement experimental measurement techniques [7]. Moreover, experimental measurements of nuclide content are the basic tool for validation of theoretical predictions. The main steps in implementing the SFM for RAW characterization in NPPs are shown in the Fig. 1.

A methodology for empirical determination of SFs is described in International Standard ISO 21238:2007 [7]. The SFM is widely used to evaluate DTM nuclides. The SFM is based on development of a correlation between ETM gamma-emitting nuclides (key nuclides $\mathrm{KN}$ ) and DTM nuclides, which are contaminated by different materials in nuclear reactor [6]. The activities of DTM nuclides in waste packages are estimated by $\mathrm{KN}$ activity measurements and subsequent multiplication of this value by SF coefficients calculated on the basis of radionuclide data obtained by sampling and radiochemical analysis (according to established ratios of radioactive concentrations of DTM nuclides/KN). The document [7] gives guidelines for the SFs used in the characterization of RAW producible in water-cooled NPPs and other types of reactor.

One of the most important and responsible steps in successful application of SFM is SF determination for all radiologically significant radionuclides, which must be measured and certified in relation to State regulation. As noted in [4], in many countries, characterization is carried out, mainly, to ensure radiation safety of personnel during the RAW management, nuclear safety and control of commercial product losses. Under the absence of control of long-lived radionuclides, the solu- 


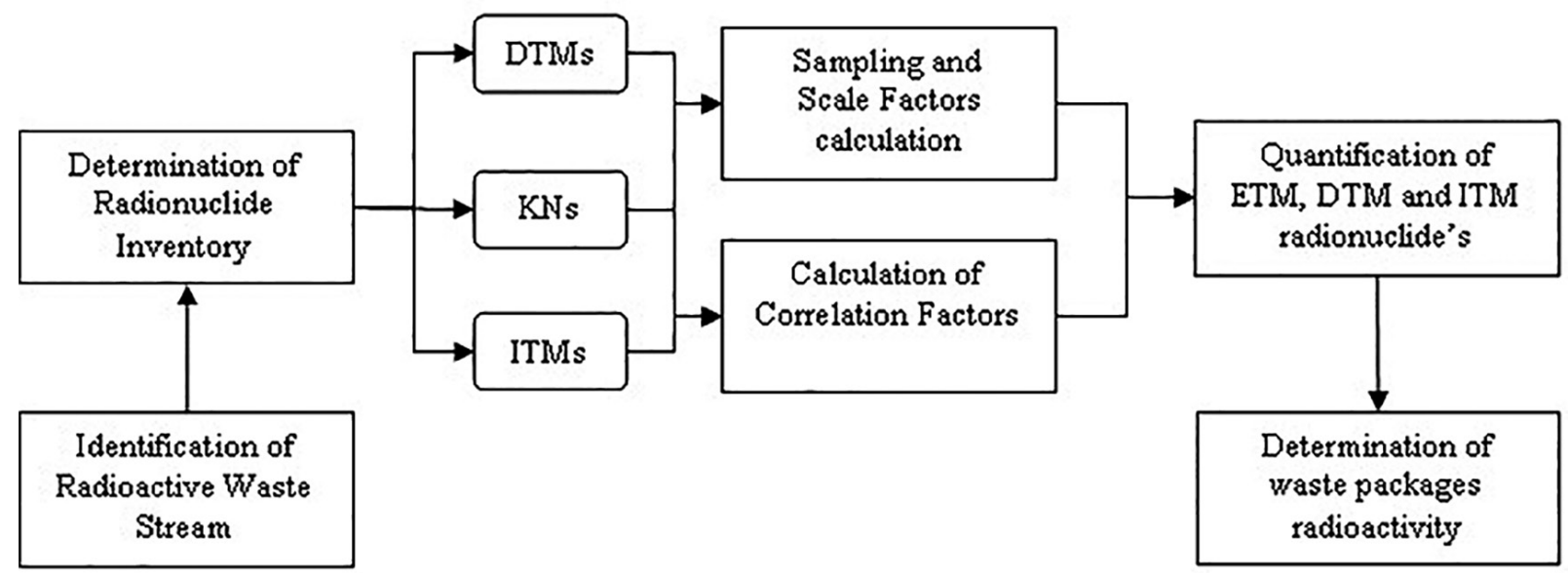

Fig. 1. SF methodology for RAW characterization in NPPs

tion of tasks to assess long-term safety of RAW dumps is difficult and, practically, impossible. For solid RAW accumulated during the normal operation of ChNPP, the list of radionuclides to be certified includes 23 radioactive isotopes, whose majority refers to DTM long-lived radionuclides [13].

Nowadays, SFM methodology was developed to be used in all NPP types: Boiling Water Reactor (BWR), Pressurized Water Reactors (PWR), Gas-cooled Reactor (GCR), water-cooled, water-moderated power reactor (WWER), High Power Channel-type Reactor (RBMK), Pressurized Heavy Water Reactor (PHWR), and others. They are, primarily, applied to operating reactors, but are also used for shutdown reactors and reactors undergoing decommissioning (Japan, Spain, Slovakia, the USA, Lithuania and Ukraine) [6]. As it is described below, some special considerations may be required for reactors undergoing decommissioning, as well as for those, which may have had major fuel damage or environmental contamination incident.

It is important to note the following thing. First, the sampling practices, calculation model and data maintenance practices may differ in various countries (for example, sampling at some stages of development process and/or sampling of waste streams). As a part of this article, we will not discuss this issue in detail, except for discussing the importance of separating waste into streams, which will be done below. An example of basic principles to determine the amount of samples, which are to be taken, may be found in [16].

Second, in the majority of countries, two main methods to calculate mean SF values are used: arithmetic mean (such as Japan, Slovenia and the UK) and geometric (logarithmic) mean (such as Brazil, Canada, France, the Republic of Korea, Italy, Spain, Sweden, Ukraine and the USA). The SF "mean value" is based on the as- sumption that the relationship between a KN and a DTM nuclide is linear over the range of activities of interest. The arithmetic mean will tend to produce a conservative (i.e. high) value, while the geometric mean will tend to produce a more representative average value when the data points are spread over several orders of magnitude. The Fig. 2 shows an example illustrating a degree of SF value overestimation with using a second data analysis method. Other countries, such as Germany, Hungary, Lithuania, Mexico and Slovakia, use a logarithm regression analysis to calculate the SF values.

Third, the KN and DTM grouping practices may also differ. In theory, $\mathrm{KN}$ selection is based on considerations relating to production mechanism, transport parameters and stream exposure in various processes. In practice, the main criterion is the ability to show that a correlation exists between the KN and the DTM nuclide. The Table 1 shows the results of established correlations between various radionuclides in the spectrum of radioactive contamination of waste, and identifies the best KN for a group of radionuclides united by general nature of their origin $[1,3,6,11,14,15]$. In all cases, the important point to be considered is, whether or not, $\mathrm{KN}$ and DTM nuclides show an 'acceptable' correlation for given circumstances. The ultimate determinant in establishing a viable $\mathrm{KN}$ is that, which is easy measurable with using gamma-spectrometry available at the point of generation or place for packaging for disposal.

Fourth, there are some cases where no reliable correlation has been found between KN and DTM nuclides. For example, development of SFs for ${ }^{3} \mathrm{H}$ and ${ }^{14} \mathrm{C}$ has been problematic in the USA for some waste streams [6]. In many of these cases, average values, theoretical values or upper bound values were used instead of SF calculated values (ITM, see Fig. 1). 


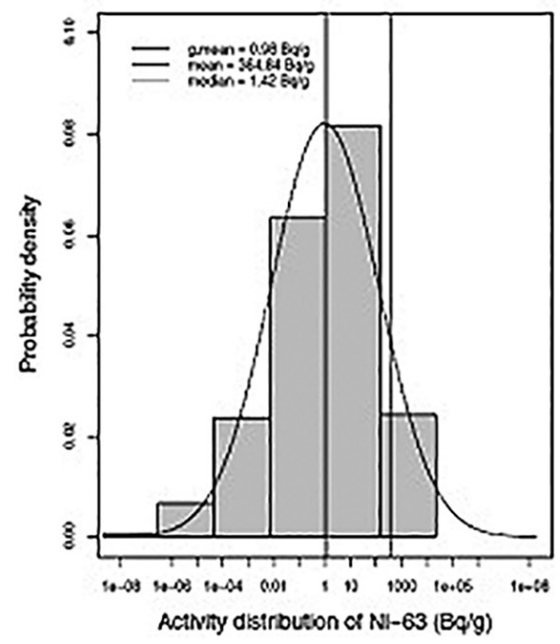

a

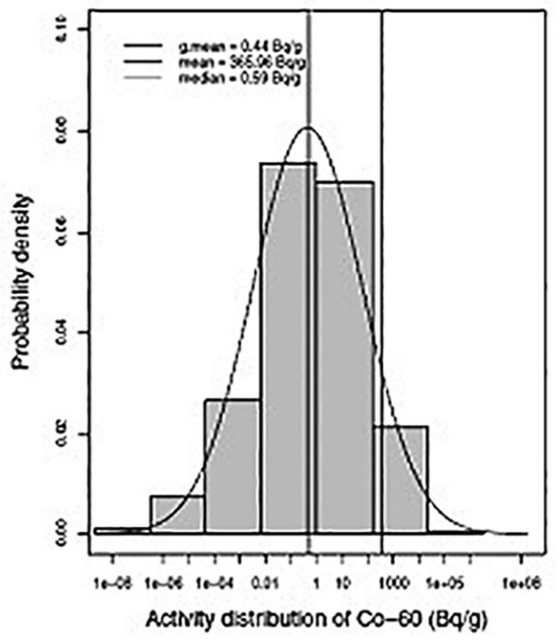

b

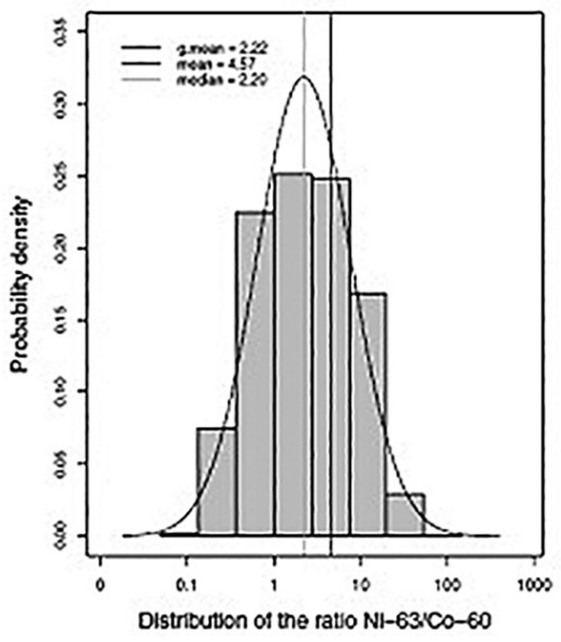

C

Fig. 2. Distribution of Ni-63 (a) and Co-60 (b) logarithm specific activities and their ratio logarithm (c) in irradiated copper [9]. Statistic parameters such as geometric mean (g. mean), mean and median, are represented together on the background of normal logarithmic curve

Table 1. Radionuclides to be, apparently, found in spent fuel treatment facility and solid RAW of normal and accident origin

\begin{tabular}{|c|c|c|c|}
\hline \multirow{2}{*}{$\begin{array}{l}\text { Number of } \\
\text { group }\end{array}$} & \multicolumn{2}{|c|}{ Groups of radionuclides } & \multirow{2}{*}{$\begin{array}{l}\text { Key nuclides } \\
\text { (tracer) }\end{array}$} \\
\hline & general characteristics & nuclides & \\
\hline 1 & $\begin{array}{c}\text { Activation products } \\
\text { (cooling water and steels) }\end{array}$ & ${ }^{10} \mathrm{Be},{ }^{3} \mathrm{H},{ }^{14} \mathrm{C},{ }^{55} \mathrm{Fe},{ }^{57} \mathrm{Co},{ }^{58} \mathrm{Co},{ }^{60} \mathrm{Co},{ }^{59} \mathrm{Ni},{ }^{63} \mathrm{Ni}$, & ${ }^{60} \mathrm{Co}$ \\
\hline 2 & Platinum-group metals & ${ }^{107} \mathrm{Pd},{ }^{106}(\mathrm{Ru}+\mathrm{Rh}),{ }^{103} \mathrm{Ru},{ }^{106} \mathrm{Ru}$ & ${ }^{106} \mathrm{Ru}$ \\
\hline 3 & Fission products & ${ }^{134} \mathrm{Cs},{ }^{135} \mathrm{Cs},{ }^{137} \mathrm{Cs},{ }^{90} \mathrm{Sr},{ }^{129} \mathrm{I},{ }^{99} \mathrm{Tc}{ }^{93} \mathrm{Zr},{ }^{94} \mathrm{Nb}$ & ${ }^{137} \mathrm{Cs},{ }^{60} \mathrm{Co}$ \\
\hline 4 & Lanthanides & ${ }^{144} \mathrm{Ce},{ }^{147} \mathrm{Pm},{ }^{151} \mathrm{Sm},{ }^{154} \mathrm{Eu},{ }^{155} \mathrm{Eu}$ & ${ }^{154} \mathrm{Eu}$ \\
\hline 5 & $\begin{array}{c}\text { Actinides } \\
\text { (similar chemical behavior) }\end{array}$ & ${ }^{244} \mathrm{Cm},{ }^{243} \mathrm{Cm},{ }^{242} \mathrm{Cm},{ }^{241} \mathrm{Am},{ }^{242 \mathrm{~m}} \mathrm{Am},{ }^{243} \mathrm{Am}$ & ${ }^{241} \mathrm{Am}$ \\
\hline 6 & $\begin{array}{c}\text { Actinides } \\
\text { (spent fuel particles in solid RAW) }\end{array}$ & $\begin{array}{c}{ }^{235} \mathrm{U},{ }^{236} \mathrm{U},{ }^{238} \mathrm{U},{ }^{237} \mathrm{~Np},{ }^{238} \mathrm{Pu},{ }^{239} \mathrm{Pu},{ }^{240} \mathrm{Pu},{ }^{241} \mathrm{Pu}, \\
{ }^{242} \mathrm{Pu},{ }^{241} \mathrm{Am},{ }^{243} \mathrm{Am}\end{array}$ & ${ }^{137} \mathrm{Cs},{ }^{60} \mathrm{Co}$ \\
\hline
\end{tabular}

And finally, the fifth one, RAW is produced from a range of activities resulting in waste streams varying by their form, activity, physical state, etc. The sources of RAW are often called as "point of origin" [1], which also include each NPP. On the example of Ignalina NPP, which is closest to Chornobyl NPP by reactor type, the main sources and transfer channels of radionuclides in the RBMK systems can be represented in the form of diagram shown in Fig. 3.

The reactor core is the main contamination source due to generation of radionuclides during neutron capture or nuclear fission and activation of reactor core components. The diagram in Fig. 3 clearly demonstrates three main routes that contaminated coolant of main circulation circuit can be further transferred to the final waste. The found features of formation of radioactive contamination of various materials and stable ratios of radionuclide ac- tivities in their mixtures make the basis in using the SFM to characterize different RAW streams. The above-mentioned features dictate the need in establishing separate SFs for the streams differing in the nature of radioactive contamination occurrence.

\section{Practical SFM application and challenges}

The measurement of the $\mathrm{KN}$ activity in waste packages is performed by one of two methods:

direct gamma assay (at the energy level associated with the $\mathrm{KN}$ );

dose rate measurement in relation to activity conversion, where gross gamma dose rate is measured at some distance from waste package surface, and is used to assume $\mathrm{KN}$ activity via a calculation model. 


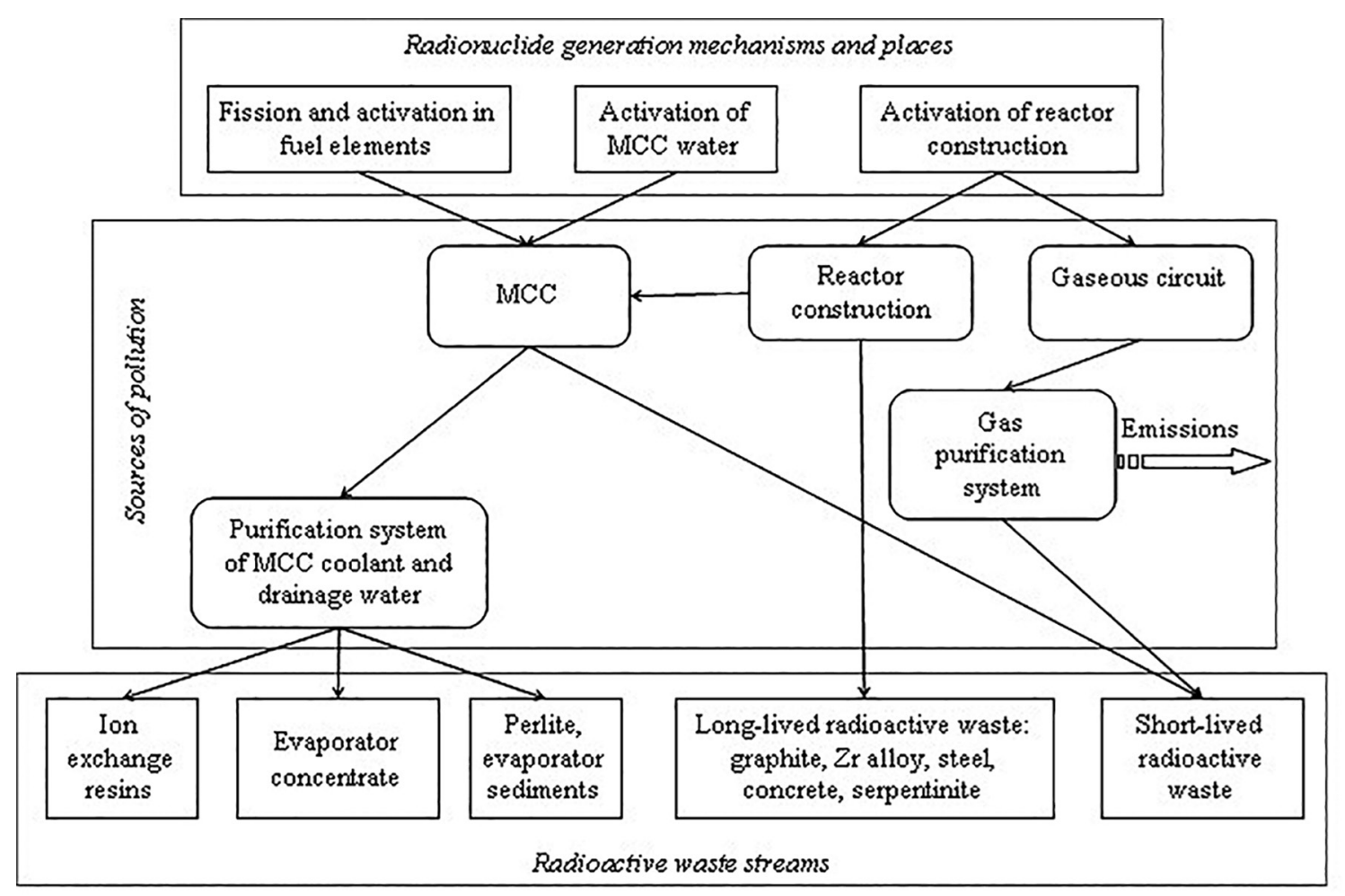

Fig. 3. Example of NPP radioactive waste streams. MCC - main circulation circuit [14]

While direct gamma assay can provide a more accurate $\mathrm{KN}$ measurement, it also requires more sophisticated equipment than the dose rate to activity conversion method. On the contrary, while dose rate to activity conversion method requires simple equipment, it still requires developing multiple conversion factors for various waste package types and geometries and/or waste types, and the use of well-defined measurement geometries in order to ensure result reproducibility.

In practice, the procedure for empirical determination of SFs values for all nuclides to be certified includes the following elements [6]:

sampling of waste streams (including determination of waste streams to be sampled, how many samples are required, how the samples are collected, etc.);

radiochemical analysis for the radionuclides of concern; analysis of data for correlation;

selection of $\mathrm{KN}$ based on evidence of correlation, modeling, or on established practice;

selection of appropriate SF calculation method (e.g. geometric mean, linear regression of logarithms);

assessment of feasibility in combining or grouping the data (for different waste streams, different reactor types, etc.); systematic or additional sampling to validate the SFs, if the nature of waste contamination has changed (e.g. significant changes to major reactor component materials and/or indication of significant fuel failuresand/or waste treatment methods, etc.), and to reduce the summary uncertainty.

Let us briefly mention another important aspect of SFs application problem that has a significant impact on the final accuracy of characterization results. The uncertainty in the SF value derived in determination stage is influenced by the following factors: number of radiochemical analyses; dispersion or variance of data (regression is based on normal distribution) and determination method used (geometric mean, linear regression of logarithm, etc.). Among the possible sources, a limited number of radiochemical analyses are the most important contributors to the summary uncertainty associated with the SF estimation. To reduce the uncertainty, additional radiochemical analysis data may be needed. However, it is necessary to consider the following thing: "The number of data points is sufficient when investment in additional sampling and measurement produces no appreciable improvement in the statistical uncertainty" [16].

In the case of reactor shutdown and of those undergoing decommissioning, ratio of $\mathrm{KN}$ to DTM nuclide will change with the time. The $\mathrm{KN}$ such as ${ }^{60} \mathrm{Co}$ and/or ${ }^{137} \mathrm{Cs}$ will decay faster than the radionuclide of interest (alpha-activity of DTM, which have typically long halflives). Thus, decay correction shall be taken into account when developing and using the SFs. This also must be considered for legacy wastes (e. g. wastes that have been stored for a long period before characterization). 
In the case of those NPPs that have undergone major fuel damage incidents or accidents, different amounts of various radionuclides may have been transported and deposited to various areas inside and outside of the plant, as based on chemical transport properties and volatility of the elements involved. The most representative example of a situation, when it is necessary to take into account such factors affecting the SFs value, is 1986 Chornobyl accident and the peculiarities in formation of radioactive contamination at different distances from the accident epicentre [10]. In 2011, a technique for determination of specific activity of radionuclides in solid RAW of emergency origin on the access port monitor directly in the back of a truck was developed and approved [15]. The results of this work can be considered as a unique example of practical implementation ofSF method to characterize solid waste, which were radioactively contaminated as a result of severe accident at NPP.

\section{Conclusions}

The analysis of information materials, revealing the basic principles of SFM, as applied to the tasks to be solved at the ChNPP, allows making the following conclusions:

1) to characterize solid RAW from the number of operational origin waste, received in specially equipped near-surface repository for solid radwaste (SESRSRW), from non-emergency Units or until April 1986, it is sufficient to follow the standard procedure for establishing the SF according to the results of data analysis for representative samples of solid RAW;

2) the most promising for implementation should be considered the procedure set out in ISO 21238 and, moreover, which is repeatedly recommended by the experts of WANO support mission;

3) the procedure for empiric establishing the SF should include: sampling of waste materials related from selected stream; laboratory analysis of radionuclides content; analysis of data for correlation results; selection of $\mathrm{KN}$ and estimation of SFs values for all DTM nuclides to be certified; systematic sampling to validate the SFs for "problematic" DTM nuclides and to reduce the summary uncertainty of certification results.

\section{References}

1. Selection of Technical Solution for the Management of Radioactive Waste. IAEA-TECDOC-1817. Vienna: IAEA, 2017, 114 p.

2. Nosovskyi A. V., Vasylchenko V. M., Klyuchnykov O. O., Yashchenko Ya. V. (2005) Decommission of Nuclear Power
Installations. Kyiv: Tekhnika, 288 p. (in Russ.)

3. IAEA-TECDOC-1537. Strategy and Methodology for Radioactive Waste Characterization. Vienna: IAEA, 2007, 182 p.

4. Alexandrova T. A., Blokhin P. A., Samoylov A. A., Kuryndin A. V. (2018) Analysis of the RW Radionuclide Composition in the Context of Long-term Safety of Its Disposal. Radioactive Waste, vol. 3, no. 2, pp. 44-51. (in Russ.)

5. Noe M., Muller W., Gens R., et al. (1998) Development of Methods to Provide an Inventory of Radiologically Relevant Radionuclides: Analytical Methods and Correlation of Data. Final Report. Luxenbourg: European Commission, 86 p.

6. Determination and Use of Scaling Factors for Waste Characterization in NPP. IAEA Nuclear Energy Series NW-T-1.18. Vienna: IAEA, 2009, 142 p.

7. ISO 21238:2007. Nuclear energy - Nuclear fuel technology Scaling Factor Method to Determine the Radioactivity of Low- and Intermediate-Level Radioactive Waste Packages Generated at Nuclear Power Plants. Geneva: International Organization for Standardization, 2009, 23 p.

8. ISO 16966:2013. Nuclear Energy - Nuclear Fuel Technology Theoretical Activation Calculation Method to Evaluate the Radioactivity of Activated Waste Generated at Nuclear Reactors. Geneva: International Organization for Standardization, 2013, 45 p.

9. Zherebtsov A. A., Varlakov A. P., Germanov A. V., Melnikov M. V., et al. (2017) Method for Estimating the Content of Alpha- and Beta-Emitting Radionuclides in Radwaste or Radiochemical Industry Using the Matrix of Gamma-emitting radionuclides. Nuclear and Radiation Safety, vol. 85, no. 3, pp. 1-9. (in Russ.)

10. Krasnov V.O., Nosovskyi A. V., Rudko V.M., Shcherbin V.M. (2016) Shelter Object: 30 Years after the Accident. Chornobyl: ISP NPP of NAS of Ukraine, 512 p. (in Ukr.)

11. Improvement of Radioactive Waste Characterization Systems at Existing Nuclear Power Plants of Ukraine and Procedures and Methodology of Clearance from Regulatory Control of Materials. Detail Task B3 report. Contract NSI/2014/341-505. Kyiv, 2017, 29 p. (in Russ.)

12. Methodology and practice in defining nuclide vectors. Final report of WANO Technical Support Mission at Chernobyl NPP (Slavutych, May 14-18, 2018). WANO-MC, 2018, 12 p. (in Russ.)

13. Criteria for acceptance of waste for burial in specially equipped near-surface repository for solid radwaste (SESRSRW). First stage of SESRSRW operation. Acceptance of RAW from SSE ChNPP PTLRW and PTSRW for burial in two symmetrical compartments of SESRSRW. Revision 5. Chornobyl, 2009, 38 p. (in Ukr.)

14. Plukis A., Remeikis V., Juodis L., Plukiene R., Lukauskas D., Gudeli A. (2008) Analysis of nuclide content in Ignalina NPP radioactive waste streams. Lithuanian J. of Phys, vol. 48, no. 4, pp. 375-379.

15. Specific activity of radionuclides in solid radwaste of Shelter Object. Procedure for conduct of measurements with using radiation monitor of automotive vehicle of 
RMAT-01-F type. PCM-ISP NPP-01-11. Chornobyl: ISP NPP of NAS of Ukraine, 2011, 32 p. (in Russ.)

16. Kashiwagi M., Muller W. (2000) Considerations on the activity concentration determination method for low-level waste packages and nuclide data comparison between different countries. Proc. Int. Conf. "Safety of Radioactive Waste Management" (Cordoba, 2000). Vienna: IAEA, pp. 175-179.

\section{О. В. Михайлов, В. О. Краснов, В. М. Безмилов}

Інститут проблем безпеки АЕС НАН Украйни, вул. Кірова, 36а, м. Чорнобиль, 07270, Украӥна

\section{Теоретичні та практичні аспекти застосування методу масштабних коефіцієнтів для характеризації твердих радіоактивних відхо- дів, що утворюються на АЕС}

Представлено короткий огляд найбільш відомих аналітичних і методичних матеріалів, присвячених питанням теорії і практики характеризації радіоактивних відходів (РАВ), які утворюються на АЕС. Розкрито базові принципи побудови методу масштабних коефіцієнтів (МК) та основні особливості його застосування в технологічному ланцюзі поводження з РАВ.

Показано, що фундаментом, який дозволяє використовувати методологію МК, є наявність функціональних взаємозв'язків між активностями різних радіонуклідів, які напрацьовуються одночасно в ході кампанії реактора і забруднюють різні матеріали. У ході спеціального дослідження необхідно: провести відбір репрезентативної вибірки проб відходів від кожного потоку матеріалів, що підлягають радіаційному контролю; в умовах лабораторії визначити вміст усіх радіонуклідів, що підлягають паспортизації; використовуючи методи статистичного аналізу даних, розрахувати середні значення МК, які дозволяють за результатами гамма-спектрометрії активності реперних радіонуклідів (РP) оцінити в упаковках РАВ активність альфа- і бета-випромінюючих радіонуклідів, вимірювання яких вимагає значних матеріальних витрат і часу (радіонукліди, що важко вимірюються - РВВ).

Наочно продемонстровано вплив основних факторів i механізмів, що формують співвідношення вмісту PBB/PP у твердих РАВ, що є характерним для реакторів типу РБМК. Визначено основні вимоги та процедури, які повинні бути відображені в методиці характеризації твердих РАВ Чорнобильської АЕС при паспортизації РВВ із використанням МК.

Ключові слова: АЕС, радіоактивні відходи, характеризація, масштабний коефіцієнт, реперні радіонукліди, важковимірювані радіонукліди, коефіцієнт кореляції.
А. В. Михайлов, В. А. Краснов, В. Н. Безмылов

Институт проблем безопасности АЭС НАН Украины, ул. Кирова, 36а, м. Чернобыль, 07270, Украина

\section{Теоретические и практические аспекты применения метода масштабных коэффициентов для характеризации твердых радиоактивных отходов, образующихся на АЭС}

Представлен краткий обзор наиболее известных аналитических и методических материалов, посвященных вопросам теории и практики характеризации радиоактивных отходов (РАО), которые образуются на АЭС. Раскрыты базовые принципы построения метода масштабных коэффициентов (МК) и основные особенности его применения в технологической цепи обращения с $\mathrm{PAO}$.

Показано, что фундаментом, позволяющим использовать методологию МК, является наличие функциональных взаимосвязей между активностями различных радионуклидов, которые нарабатываются одновременно в ходе кампании реактора и загрязняют различные материалы. В ходе специального исследования необходимо: провести отбор репрезентативной выборки проб отходов от каждого потока материалов, подлежащих радиационному контролю; в лабораторных условиях определить содержание всех радионуклидов, подлежащих паспортизации; используя методы статистического анализа данных, рассчитать средние значения МК, которые позволяют по результатам гамма-спектрометрического определения активности реперных радионуклидов (РP) в упаковках РАО оценить активность альфа- и бета-излучающих радионуклидов, измерение которых требует больших материальных затрат и времени (трудноизмеряемые радионуклиды - ТИР).

Наглядно продемонстрировано влияние основных факторов и механизмов, формирующих соотношение активностей ТИР/РР в твердых $\mathrm{PAO}$, характерное для реакторов типа РБМК. Определены основные требования и процедуры, которые должны быть отражены в методике характеризации твердых РАО Чернобыльской АЭС при паспортизации ТИР с использованием МК.

Ключевые слова: АЭС, радиоактивные отходы, характеризация, масштабный коэффициент, реперные радионуклиды, трудноизмеряемые радионуклиды, коэффициент корреляции.

Надійшла 11.02.2019

Received 11.02.2019 


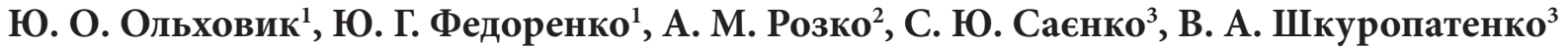 \\ ${ }^{1}$ ДУ «Інститут геохімії навколишнього середовища НАН України», просп. Академіка Палладіна, 34а, м. Київ, 03142, Україна \\ ${ }^{2}$ Інститут геохімї, мінералогії та рудоутворення НАН України ім. М. П. Семененка, просп. Академіка Палладіна, 34, \\ м. Київ, 03142, Україна \\ ${ }^{3}$ Інститут фозики твердого тіла, матеріалознавства та технологій Національного наукового изентру «Харківський \\ фізико-технічний інститут», вул. Академічна, 1, м. Харків, 61108, Украйна
}

\title{
Цементування боратвмісних рідких радіоактивних відходів за підвищеної температури
}

Ключові слова:

радіоактивні відходи, цементування,

радіаційна стійкість, швидкість вилуговування, початок тужавлення, механічна міцність.
Розглянуто особливості цементування боратвмісних концентрованих сольових розчинів. Внесення до пересиченого розчину $(800$ г/дм³ $)$ імітату кубового залишку центрів кристалізації у вигляді дрібнодисперсних порошків бентоніту та портландцементу сприяє утворенню в компаундах великої кількості дрібних кристаликів солей, у тому числі метаборату натрію. Зразки цементних компаундів у цьому випадку мають межу міцності на стиск більше 4,9 МПа, задовільна міцність зразків зберігається після $\gamma$-опромінення дозою 10 кГр та після 30 циклів заморожування відтаювання. Нормована швидкість вилуговування $10^{-3} \mathrm{r} /\left(\mathrm{cm}^{2} \cdot\right.$ доба) досягається на $107 \div 446$ добу. Залежність нормованих показників від складу компаундів надається відповідними рівняннями.

\section{Вступ}

Під час експлуатації атомних електростанцій (АЕС) з водо-водяними енергетичними реакторами (ВВЕР) утворюються і накопичуються великі об'єми рідких радіоактивних відходів (РАВ) низької і середньої активності у вигляді сольових концентратів. Кондиціонування рідких відходів, що містять переважну частину активності, накопиченої у сховищах АЕС, передбачає іх переведення в стабільну фізико-хімічну форму, яка здатна максимально обмежити можливість міграції радіонуклідів у довкілля і бути прийнятною для захоронення в поверхневі сховища на майданчику комплексу «Вектор». Об’єм накопиченого кубового залишку (КЗ) на АЕС Державного підприємства «НАЕК “Енергоатом"» на 31.12.2017 р. становить $9000 \mathrm{~m}^{3}$ із сумарною активністю $\approx 100$ ТБк. КЗ є сольовими розчинами з високою концентрацією, як правило, нітратів і боратів натрію, з питомою активністю до $10^{8}$ Бк/дм³ містять продукти поділу, радіонукліди корозійного походження й різні речовини, які використовуються для підтримки водно-хімічного режиму і дезактивації устаткування.

Найбільш розповсюдженим методом кондиціювання середньо- і низькоактивних відходів є цементування [1-3]. Недоліком згаданого методу є значне збільшення об'єму і, відповідно, вартості витрат у разі довготривалого зберігання i захоронення в поверхневих сховищах. Проте як матриці для іммобілізації рідких РАВ широко використовуються цементні компаунди на основі портландцементу [4]. Ця технологія налічує не один десяток років і дотепер ії використання $\epsilon$ актуальним у зв'язку з можливістю отримання механічно міцних і негорючих отверджених рідких РАВ.

На Ростовській АEC (Російська Федерація) впроваджено метод цементування КЗ із солевмістом 700-750 г/дм ${ }^{3}$ із застосуванням портландцементу, бентоніту і $\mathrm{NaOH}$ [5]. Матриця являє собою

() Ю. О. Ольховик, Ю. Г. Федоренко, А. М. Розко, С. Ю. Саєнко, В. А. Шкуропатенко 
цементно-глиняну суміш (суміш бентоніту і портландцементу марки М-500 (ПЦ 1-500) російських виробників у пропорції $1: 9)$. Рецептура складу цементного компаунду: концентрат КЗ - 38 \%; портландцемент + бентоніт - $59 \%$; розчин $\mathrm{NaOH}(46 \%)-3 \%$. Вміст солей в отриманих цементних компаундах складає $22 \%$.

Згідно з економічними оцінками різних способів переробки рідких РАВ економічно виправданим цементування може стати лише якщо КЗ має концентрацію солей не менше 700-800 г/л [4], однак наразі не існує випарних установок, здатних точно забезпечувати задану концентрацію сольового розчину рідких РАВ для досягнення відповідної якості цементного компаунда. У цьому випадку може бути корисним аналітичне прогнозування нормованих показників, базоване на відповідних експериментальних рівняннях.

Відповідно до національного законодавства РАВ підлягають захороненню лише у твердому стані. Однак конкретних вимог щодо характеристик упаковок РАВ (і відповідно матриць, які вміщують РАВ) рекомендації [6] не наводять, оскільки згадані параметри визначаються під час проектування сховища шляхом встановлення критеріїв приймання відходів до нього [7]. Установлені критерії і вимоги до приймання кондиційованих відходів від заводу з переробки рідких РАВ та заводу з переробки твердих РАВ ДСП «Чорнобильська AEC» для захоронення у два відсіки спеціально обладнаного приповерхневого сховища твердих РАВ [7] мають тимчасовий характер, дійсні тільки на час завантаження двох відсіків і не можуть розглядатися як нормативи для продуктів кондиціювання боратвмісних рідких РАВ АЕС з реакторами типу ВВЕР.

3 огляду на відсутність в Україні відповідного загальнодержавного нормативного документу, автори роботи орієнтувались на загальні технічні вимоги до цементованих РАВ, що наведені у стандарті Російської Федерації ГОСТ Р 51883-2002
«Отходы радиоактивные цементированные» [8] (табл. 1).

Метою роботи було дослідити вплив температури та застосування дисперсного бентоніту під час цементування імітату боратвмісних рідких РАВ на нормовані показники компаундів.

\section{Експериментальна частина}

Згідно з вимогами нормативних документів означені показники (табл. 1) необхідно вимірювати одночасно, тобто кожна партія компаундів повинна відповідати значенням усіх нормованих показників. Для експериментів використовувався імітат КЗ сольового складу (надалі солі імітату).

Сольовий склад імітату кубового залишку, \% мас.

$\mathrm{Na}_{2} \mathrm{~B}_{4} \mathrm{O}_{7} \cdot 5 \mathrm{H}_{2} \mathrm{O}$ 60,1

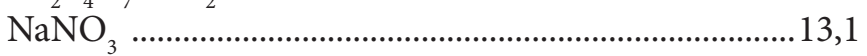

$\mathrm{NaCl}$

$\mathrm{KOH}$

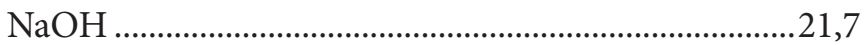

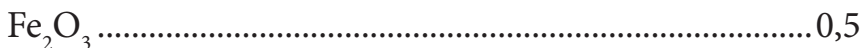

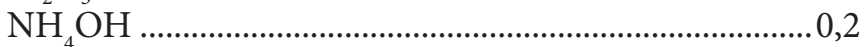

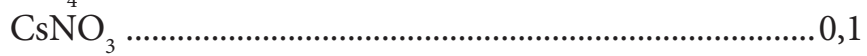

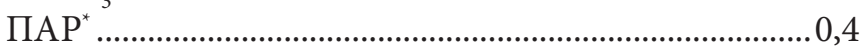

*Як поверхнево-активну речовину (ПАР) використано препарат «Щит», який застосовується на АЕС України для дезактивації обладнання і прання одягу персоналу.

Під час вивчення поведінки солей імітату у водному розчині було встановлено, що при розчиненні у воді температура розчину (імітату) підвищується вище $60{ }^{\circ} \mathrm{C}$. За підвищеної температури імітат представляє собою рідкий розчин. У разі охолодження імітату до температури $26 \div 27{ }^{\circ} \mathrm{C}$ відбувається його пересичення через відсутність центрів кристалізації. Надалі починається кристалізація, і температура підвищується до $40 \div 42{ }^{\circ} \mathrm{C}$. Після підвищення температу-

Таблиця 1. Характеристики цементованих рідких РАВ (компаундів)

\begin{tabular}{|c|c|c|}
\hline Показник & $\begin{array}{c}\text { Значення } \\
\text { показника }\end{array}$ & Метод випробування \\
\hline Максимальна швидкість вилуговування ${ }^{137} \mathrm{Cs}$, г/(cм² д доба) & $10^{-3}$ & ГОСТ 29114-91 \\
\hline Мінімальна механічна міцність (границя міцності на стиснення), МПа & 4,9 & ГОСТ 310.4-81 \\
\hline Морозостійкість (кількість циклів замерзання/відмерзання) & 30 & ГОСТ 10060.1-95 \\
\hline Радіаційна стійкість під час опромінення, Гр & $1 \cdot 10^{6}$ & \multirow{2}{*}{$\begin{array}{c}\text { Вимірювання } \\
\text { механічної міцності }\end{array}$} \\
\hline Стійкість до перебування у воді, діб & 90 & \\
\hline
\end{tabular}




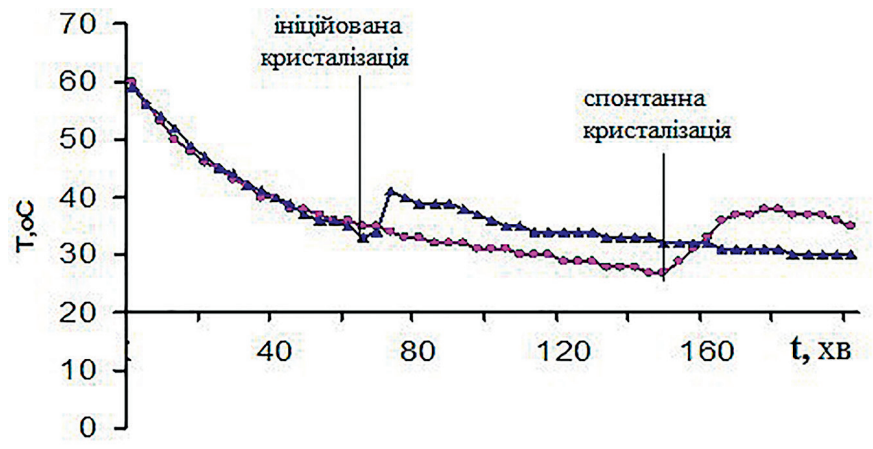

$\multimap$ імітат $\simeq$ імітат+бентоніт

Рис. 1. Температурний хід за охолодження імітату

ри відбувається ії зниження, і з'являються кристали переважно метаборату, які поступово виростають до розмірів $2 \div 3$ мм, що посилює неоднорідність компаундів.

Якщо за температури $40 \div 60{ }^{\circ} \mathrm{C}$ до початку спонтанної кристалізації ввести в імітат центри кристалізації у вигляді дрібних частинок бентоніту фр. <100 мкм, то хід охолодження пересиченого розчину змінюється і кристалізація відбувається раніше за більш високої температури (рис. 1).

У цьому випадку формується значна кількість дуже дрібних кристаликів, які входять у цементну матрицю, що менше впливає на міцність та радіаційну стійкість компаундів.

Подібне слід очікувати і в разі поєднання з імітатом частинок портландцементу. Таким чином, створення компаундів доцільно робити за підвищеної температури, тому всі зразки компаундів для досліджень були виготовлені за температури імітату $40 \div 42{ }^{\circ} \mathrm{C}$.

Виконання роботи проводилось шляхом аналізу результатів факторного експерименту [9]. Фактора- ми були обрані масові кількості солей імітату, води, цементу, що був поєднаний з бентонітом у співвідношенні 10 : 1 (надалі цемент).

Відповідно до факторного експерименту базо-

вими обрано такі масові співвідношення:

вода /цемент = 0,5;

вода $/$ солі імітату $=1,0$;

бентоніт $/$ цемент $=0,1$.

\section{Склад базового компаунда, \%}

Солі імітату ............................................................. 23,8

Портландцемент ..................................................... 47,6

Бентоніт .............................................................. 4,

Вода...................................................................... 23,

Надалі означені три фактори варіювалися на $\pm 10 \%$ відносно базових значень. Остаточна маса компонентів у зразках наведена в табл. 2.

Для проведення експериментів були виготовлені зразки різних розмірів. Межа міцності на стиск вимірювалась на зразках $5 \times 5 \times 5$ см [10], опромінювались зразки розміром 1,5 × 1,5 × 1,5 cм, що обумовлено геометрією каналу опромінення. Швидкість вилуговування визначалась на зразках із зовнішньою поверхнею близько $80 \mathrm{~cm}^{2}$.

Випробування на стиск зразків компаундів проведені на електромеханічному пресі марки ZD 10/90 (виробництво - Німеччина), максимальне навантаження - 10 т. Імітацію опромінення здійснювали на прискорювачі електронів ЛУ-10 з енергією $10 \mathrm{MeB}$, середній струм пучка - 800 мкА, частота проходження імпульсів - 250 Гц, швидкість вилуговування стабільного цезію визначалась на двохпроменевому атомно-абсорбційному спектрофотометрі (AA 8500F «Jarrel-Н»), тужавлення зразків компаундів - за допомогою приладу Віка.

Таблиця 2. Початок тужавлення і маса компонентів у зразках для факторного експерименту

\begin{tabular}{|c|c|c|c|c|}
\hline \multirow{2}{*}{ Номер серії } & Початок & \multicolumn{3}{|c|}{ Маса, г } \\
\cline { 3 - 5 } & тужавлення, хв & солі імітату & вода & цемент \\
\hline M-350/1 & 115 & 416 & 416 & 915,2 \\
\hline M-350/1a & 110 & 416 & 416 & 915,2 \\
\hline M-352/1 & 160 & 457 & 457 & 1006,5 \\
\hline M-352/2 & 190 & 457 & 374 & 823,9 \\
\hline M-352/3 & 70 & 457 & 374 & 1006,5 \\
\hline M-352/4 & 75 & 457 & 457 & 823,9 \\
\hline M-352/5 & 315 & 374 & 457 & 1006,5 \\
\hline M-352/6 & 225 & 374 & 374 & 823,9 \\
\hline M-352/7 & 85 & 374 & 374 & 1006,5 \\
\hline M-352/8 & 95 & 374 & & 823,9 \\
\hline
\end{tabular}




\section{Результати досліджень та їх аналіз}

Початок тужавлення. Інтервал часу від закінчення поєднування всіх компонентів цементних компаундів до початку їх тужавлення $є$ важливою технологічною характеристикою водоцементних сумішей.

Результати вимірювань показали, що залежно від складу компаундів початок тужавлення становить від 70 хв (зразок 352/3) до 215 хв (зразок 352/5) (табл. 2).

Отримане рівняння регресії у цьому випадку виглядає так:

$$
\mathrm{t}_{\text {туж }}=189,6+0,29 m_{\mathrm{c}}+1,32 m_{\mathrm{B}}-0,11 \mathrm{~m}_{\text {प' }} R^{2}=0,94,
$$

де $t_{\text {туж }}$ - початок тужавлення, хв; $m_{c}$ - маса солей імітату в компаунді, г; $m_{\text {в }}$ маса води в компаунді, г; $m_{\text {ц }}$ - маса цементу в компаунді, г.

Рівняння показує, що на початок тужавлення найбільше впливає кількість води у компаунді, а найменше - кількість цементу з бентонітом.

Механічна мічність. Зразки компаундних матеріалів були випробувані на міцність під час одноосного стискування. Переважна кількість зразків здебільшого зберегла форму куба з тріщинами по вертикальних гранях. Аналіз отриманих результатів показав, що межа міцності всіх зразків перевершує нормований показник 4,9 МПа, і складає 8,2 $\div$ 19,8 МПа. Визначено рівняння регресії, яке пов’язує показник міцності $(\delta)$ зі складом компаундів:

$$
\delta=-23,3+0,006 m_{\mathrm{c}}+0,045 m_{\mathrm{B}}+0,019 m_{\text {म् }} .
$$

Коефіцієнт кореляції між експериментальними та розрахованими за рівнянням результатами складає $R^{2}=0,71$. Такий коефіцієнт свідчить, що у вивченні межі міцності були недостатньо враховані чинники температури.

Унаслідок змішування імітату з цементом температура суміші знижується залежно від маси цементу та його температури. Подальше іiі зниження залежить від маси зразків, відповідно цементування відбувається за значно нижчих температур. Вплив температури як додаткового чинника має бути вивчений додатково.

Експеримент щодо визначення механічних властивостей компаундів, які безперервно перебували у воді 90 діб, показав, що за цей час межа міцності знизилась приблизно на 20 \%, але майже вдвічі перевищувала нормований показник.

Швидкість вилуговування. Підрахунки отриманих даних щодо вилуговування стабільного цезію дали результати, відображені в табл. 3 .

У разі подовження терміну експерименту швидкість вилуговування зменшується і за деякий час виходить на нормований показник.

Термін $J_{\text {доба }}$ за який швидкість вилуговування стає $1 \cdot 10^{-3} \mathrm{\Gamma} /\left(\mathrm{cm}^{2} \cdot\right.$ доба $)$, описується рівнянням

$$
J_{\text {доба }}=1867+0,027 m_{\mathrm{c}}-2,96 m_{\mathrm{B}}-0,51 m_{\text {ц }} \text {. }
$$

Коефіцієнт кореляції $R^{2}=0,96$.

3 рівняння видно, що найбільше впливає на термін виходу на нормований показник кількість води у компаунді, зі збільшенням якої термін виходу скорочується.

Радіаційна стійкість. Сольовий плав, класифікований як середньоактивні відходи, має активність $n 10^{7}$ Бк/л. Виконані розрахунки свідчать, що за 160 років зберігання цементний компаунд набере дозу 0,41 кГр. Враховуючи це, а також можливість нерівномірного розподілу радіонуклідів цезію в цементних компаундах, що може збільшити дозу самоопромінення окремих компаундів, доза імітаційного $\gamma$-опромінення була підвищена до 10 кГр. Загальний вигляд досліджуваних зразків до та після $\gamma$-опромінення представлено на рис. 2.

Під час візуального огляду опромінених зразків слідів механічного руйнування у вигляді відколів та

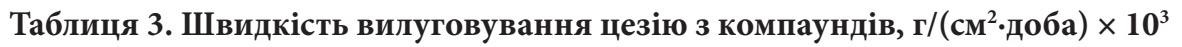

\begin{tabular}{|c|c|c|c|c|c|c|c|}
\hline \multirow{2}{*}{$\begin{array}{c}\text { Номер } \\
\text { зразка }\end{array}$} & $\begin{array}{c}\text { Термін виходу } \\
\text { на нормований } \\
\text { показник }\end{array}$ & \multicolumn{7}{|c|}{ Термін вилуговування, доба } \\
\cline { 3 - 8 } & 1 & 1 & 3 & 7 & 14 & 21 & 28 \\
\hline M352/1 & 107 & 64,5 & 24 & 11,5 & 6,2 & 4,4 & 3,3 \\
\hline M352/2 & 251 & 42,0 & 23 & 12,5 & 7,4 & 5,3 & 4,4 \\
\hline M352/4 & 446 & 44,0 & 27,9 & 16,0 & 9,4 & 6,7 & 5,7 \\
\hline M352/6 & 178 & 45,0 & 23,5 & 12,6 & 7,3 & 3,9 & 4,5 \\
\hline M352/7 & 355 & 42,0 & 24,2 & 13,8 & 8,2 & 6,1 & 5,0 \\
\hline
\end{tabular}




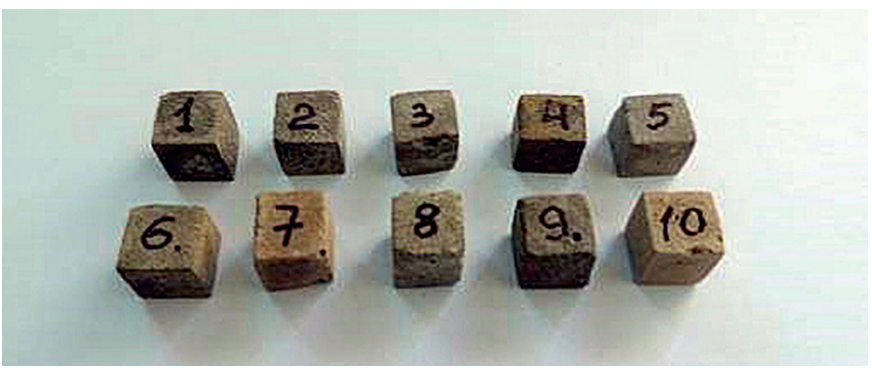

a

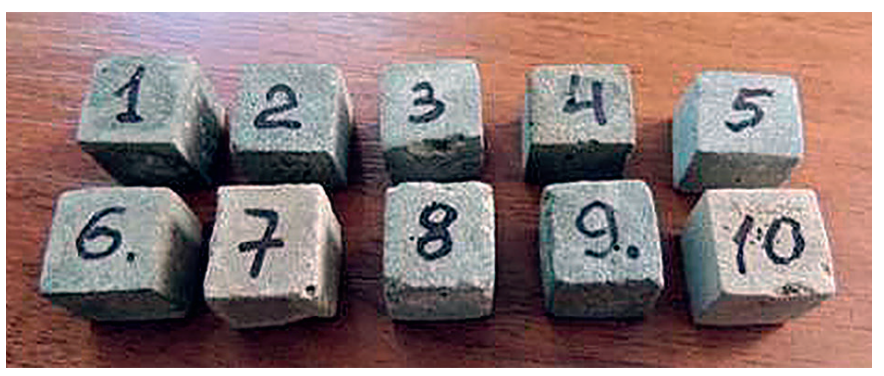

6

Рис. 2. Вигляд зразків: а - до опромінення; б - після $\gamma$-опромінення дозою 10 кГр

Таблиця 4. Межа міцності на стиск зразків цементних компаундів, неопромінених та $\gamma$-опромінених до дози 10 кГр

\begin{tabular}{|c|c|c|c|c|c|}
\hline \multirow{2}{*}{$\begin{array}{l}\text { Номер } \\
\text { зразка }\end{array}$} & \multicolumn{2}{|c|}{ До опромінення } & \multicolumn{2}{|c|}{ Після опромінення } & \multirow{2}{*}{$\begin{array}{c}\text { Зміна міцності після } \\
\text { опромінення, \% }\end{array}$} \\
\hline & зусилля, кгс & межа міцності, МПа & зусилля, кгс & межа міцності, МПа & \\
\hline M-350 & 230 & 10,0 & 275 & 12,0 & +20 \\
\hline M-351 & 220 & 9,6 & 230 & 10,0 & +4 \\
\hline M-352/1 & 535 & 23,3 & 275 & 12,0 & -48 \\
\hline M-352/2 & 365 & 15,9 & 365 & 15,9 & 0 \\
\hline M-352/3 & 355 & 15,5 & 325 & 14,2 & -8 \\
\hline M-352/4 & 415 & 18,1 & 285 & 12,4 & -31 \\
\hline M-352/5 & 225 & 9,8 & 325 & 14,2 & +45 \\
\hline M-352/6 & 500 & 21,8 & 345 & 15,0 & -31 \\
\hline M-352/7 & 445 & 19,4 & 375 & 16,3 & -16 \\
\hline M-352/8 & 240 & 10,5 & 195 & 8,5 & -19 \\
\hline
\end{tabular}

тріщин не виявлено. Також не виявлено зміни кольору в опромінених зразках порівняно з неопроміненими. Для порівняння значення межі міцності на стиск опромінених та неопромінених зразків наведено у табл. 4.

Значення міцності на стиск зразків після імітаційного $\gamma$-опромінення наведені поряд зі значенням міцності зразків еквівалентних складів та в еквівалентному віці твердіння в повітряно-вологих умовах.

3 таблиці видно, що межа міцності на стиск більшості зразків зменшується, крім зразків № М-350, M-351 та M-352/5, для яких характерне підвищення межі міцності після опромінення. Зменшення межі міцності зразків після $\gamma$-опромінення, ймовірно, зумовлене тим, що за інтенсивного $\gamma$-опромінення відбувається нагрів зразків і відповідно видалення незв'язаної води [8].

Морозостійкість. Зразки цементних компаундів партій № M-350, M-351 та M-352/1-8 були випробувані на морозостійкість (30 циклів заморожування - відтанення). Отримані результати наведено в табл. 5.
Отримані дані випробувань на морозостійкість зразків показали, що найкращі показники морозостійкості спостерігаються у зразків партії № M-352/3, зміна міцності яких після випробування на морозостійкість становить 29,4 \% за допустимої межі в 25 \%. Характерно, що зразки цієї партії показали також і високу радіаційну стійкість, демонструючи низьке зменшення міцності після опромінення - 8 \%. Випробувані на морозостійкість зразки партій № М-352/3, M-352/4 та M-352/7 залишалися достатньо міцними і перевищували нормований показник 4,9 МПа, наведений у [8]. Слід зазначити, що за показниками механічної міцності зазначені зразки також перевищують параметри структурної стабільності іммобілізованих у матрицю рідких РАВ, що наведені у галузевому стандарті ДП «НАЕК “Енергоатом”» [11].

\section{Висновки}

У процесі роботи з цементування імітату боратвмісних рідких РАВ із сольовим вмістом 800 г/дм³ за температури вище спонтанної кристалізації $\left(40{ }^{\circ} \mathrm{C}\right)$ та 3 
Таблиця 5. Результати випробувань зразків на міцність на стиск після 30 циклів заморожування

\begin{tabular}{|c|c|c|c|c|c|}
\hline \multirow{2}{*}{$\begin{array}{l}\text { Номер } \\
\text { зразка }\end{array}$} & \multicolumn{2}{|c|}{ Контрольні зразки } & \multicolumn{2}{|c|}{ Після тесту на морозостійкість } & \multirow{2}{*}{$\begin{array}{c}\text { Зміна міцності } \\
\text { після тесту на } \\
\text { морозостійкість, \% }\end{array}$} \\
\hline & міцність, МПа & $\begin{array}{c}\text { середнє значення, } \\
\text { МПа }\end{array}$ & міцність, МПа & $\begin{array}{c}\text { середнє значення, } \\
\text { МПа }\end{array}$ & \\
\hline M-352/3 (1) & 12,2 & \multirow{2}{*}{13,1} & - & - & \multirow{4}{*}{$-29,4$} \\
\hline$M-352 / 3(2)$ & 14,0 & & - & - & \\
\hline M-352/3 (3) & - & - & 9,1 & \multirow{2}{*}{9,25} & \\
\hline M-352/3 (4) & - & - & 9,4 & & \\
\hline $\mathrm{M}-352 / 4(1)$ & 13,3 & \multirow{2}{*}{14,4} & - & - & \multirow{4}{*}{$-44,8$} \\
\hline M-352/4 (2) & 15,5 & & - & - & \\
\hline M-352/4 (3) & - & - & 7,6 & \multirow{2}{*}{7,95} & \\
\hline M-352/4 (4) & - & - & 8,3 & & \\
\hline M-352/7 (1) & 25,3 & \multirow{2}{*}{22,55} & - & - & \multirow{4}{*}{$-41,7$} \\
\hline M-352/7 (2) & 19,8 & & - & - & \\
\hline M-352/7 (3) & - & - & 11,2 & \multirow{2}{*}{13,15} & \\
\hline M-352/7 (4) & - & - & 15,1 & & \\
\hline
\end{tabular}

застосуванням бентонітового порошку фр. < 100 мкм у співвідношенні з цементом 1 : 10, отримано результати:

1. Досліджені зразки мали межу міцності на стиск більше 4,9 МПа, швидкість вилуговування стабільно-

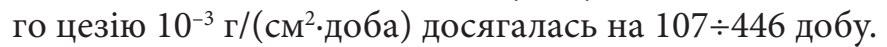
Зразки після $\gamma$-опромінення дозою 10 кГр зберігали високу міцність на стиск і відповідали регламентованим вимогам. Міцність зразків на стиск після 30 циклів заморожування була вище регламентованої величини.

2. Отримано рівняння, які пов'язують маси солей імітату, води та цементу і бентоніту з терміном початку тужавлення, межею міцності на стиск та терміном досягання нормованого показника під час вилуговування. Рівняння дозволяють враховувати зміну величин показників при оптимізації співвідношень між компонентами.

3. Спосіб цементування рідких РАВ за підвищених температур після вивчення впливу температури на нормовані показники компаундів різного компонентного складу може мати практичне застосування, якщо факторами (аргументами) додатково розглядати температуру та щільність сольового концентрату.

Вважаємо необхідною розробку національного нормативного документа, який би визначив загальні технічні умови до цементованих РАВ (цементних компаундів), отриманих введенням рідких РАВ у матриці на основі неорганічних в'яжучих речовин.

\section{Список використаної літератури}

1. Козлов П. В. Цементирование кубовых остатков АЭС с размещением компаунда в хранилищах наливного типа / П. В. Козлов, О. М. Слюнчев, К. В. Кирьянов и др. // Атомная энергия. - 2011. - Т. 111. - № 3. С. 148-154.

2. Козлов П. В. Цементирование как способ отверждения жидких радиоактивных отходов / П. В. Козлов, О. М. Слюнчев, С. И. Ровный и др. // Цемент и его применение. - 2009. - Вып. 6. - С. 67-72.

3. Ершов Б. Г. Иммобилизация средне- и высокоактивных отходов в цементную матрицу: влияние облучения на образование газов и выщелачивание радионуклидов / Б. Г. Ершов, Т. К. Юрик и др. // Вопросы радиационной безопасности. - 2008. - № 1.C. 3-15.

4. Маслов М. В. Исследование схем обращения с накопленными радиоактивными отходами в целях их подготовки для окончательной изоляции / М. В. Маслов, В. С. Гупало, В. Н. Чистяков // Горный информационно-аналитический бюллетень. - 2012. № 1. - С. 160-164.

5. Ростовская АЭС эксплуатирует установку цементирования жидких радиоактивных отходов // EnergyLand. info. - Режим доступа: http://www.energyland.info/ analitic-show-104136.- Название с экрана.

6. РД 306.4.098-2004. Рекомендації щодо встановлення критеріїв приймання кондиційованих радіоактивних відходів на захоронення у приповерхневих сховищах 
[затверджено Наказом Державного комітету ядерного регулювання України № 160 від 25.10.2004 р.].

7. Критерії приймання радіоактивних відходів на захоронення в спеціально обладнаному приповерхневому сховищі твердих радіоактивних відходів (СОПСТРВ). Перший етап експлуатації СОПСТРВ. Приймання РАВ від ЗПРРВ та ЗПТРВ ДСП ЧАЕС для захоронення в два симетричних відсіки СОПСТРВ. - Чорнобиль, 2009. - 38 c.

8. ГОСТ Р 51883-2002. Отходы радиоактивные цементированные. Общие технические требования / Госстандарт России. - М. : ИПК Издательство стандартов, 2002. - 7 с.

9. Новик Ф. С. Оптимизация процессов технологии металлов методами планирования экспериментов / Ф. С. Новик, Я. Б. Арсов. - М. : Машиностроение; София : Техника, 1980. - 304 с.

10. ASTM C293/C293M-10. Standard Test Method for Flexural Strength of Concrete (Using Simple Beam With Center-Point Loading) / ASTM International. - 2010. doi: 10.1520/C0293_C0293M-10.

11. Короткоіснуючі низько- та середньоактивні відходи АЕС. Вимоги до кінцевого продукту переробки СОУ ЯЕК 1.037:2013. Затверджено наказом Міністерства енергетики та вугільної промисловості України від 28.10.2013 № 790. - Київ, 2013.

\section{Ю. А. Ольховик ${ }^{1}$, Ю. Г. Федоренко ${ }^{1}$,} А. Н. Розко ${ }^{2}$, С. Ю. Саенко ${ }^{3}$ В. А. Шкуропатенко

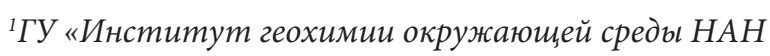
Украины», просп. Академика Палладіна, 34а, г. Киев, 03142, Украина

${ }^{2}$ Институт геохимии, минералогии и рудообразования НАН Украины им. Н. П. Семененко, просп. Академика Палладина, 34, г. Киев, 03142, Украина

${ }^{3}$ Институт физики твердого тела, материаловедения и технологий ННЦ «Харьковский бизико-технический институт», ул. Академическая, 1, г. Харьков, 61108, Украина

\section{Цементирование боратсодержащих жидких радиоактивных отходов при повышенной температуре}

Рассмотрены особенности цементирования боратсодержащих концентрированных солевых растворов. Внесение в перенасыщенный раствор 800 г/дм³ солей имитата центров кристаллизации в виде порошка бентонита и портландцемента способствует образованию в компаун- дах большого количества мелких кристалликов солей, в том числе метабората натрия.

Образцы цементных компаундов в этом случае имеют предел прочности на сжатие больше 4,9 МПа, удовлетворительная прочность образцов сохраняется после $\gamma$-облучения дозой 10 кГр и после 30 циклов замораживания - оттаивания. Нормированная скорость выщелачивания $10^{-3} \mathrm{r} /\left(\mathrm{cm}^{2} \cdot\right.$ сутки $)$ достигается на $107 \div 446$ сутки.

Зависимость нормированных показателей от состава компаундов приводится в соответствующих уравнениях.

Ключевые слова: радиоактивные отходы, цементирование, радиационная стойкость, скорость выщелачивания, начало схватывания, механическая прочность.

Yu. A. Olkhovik ${ }^{1}$, Yu. G. Fedorenko', A. N. Rozko' ${ }^{2}$, S. Yu. Saenko ${ }^{3}$, V. A. Shkuropatenko ${ }^{3}$

${ }^{1} S I$ "The Institute of Environmental Geochemistry of the National Academy of Sciences of Ukraine”, 34 a, Palladin ave., Kyiv, 03142, Ukraine

${ }^{2}$ M. P. Semenenko Institute of Geochemistry, Mineralogy and Ore Formation of the National Academy of Sciences of Ukraine, 34, Palladin ave., Kyiv, 03142, Ukraine

${ }^{3}$ Institute of Solid-State Physics, Materials Science and Technology of the National Science Center "Kharkov Institute of Physics and Technology", 1, Akademichna st., Kharkiv, 61108, Ukraine

\section{Cementation of Boron-Containing Liquid Radioactive Waste at Elevated Temperature}

The features of cementation of borate-containing concentrated salt solutions, which, in their composition simulate liquid radioactive solutions of atomic power plants with WWER reactors, are considered. The addition of salts of imitate of crystallization centers in the form of bentonite powder and portland cement in an over-saturated solution $\left(800 \mathrm{~g} / \mathrm{dm}^{3}\right)$ promotes the formation of a large number of small crystals of salts, including sodium metaborate, in the compounds.

The purpose of the work was to investigate the effect of temperature and the bentonite during cementation of borate liquid radionuclide radwaste imitation on the normalized indexes of compounds. Tests for compression of samples of compounds were carried out on the electromechanical press of the brand ZD 10/90 (production - Germany), the maximum load - 10 t. Imitation of irradiation was carried out on an electron accelerator LU-10 with energy of $10 \mathrm{MeV}$, the rate of leaching of stable cesium was determined by an atomic absorption spectrophotometer AA 8500F «Jarrel-H», annealing of samples 
of compounds - using the device Vick.

The samples of cement compounds that have been synthesized under these conditions have a compressive strength of more than $4.9 \mathrm{MPa}$, and the satisfactory strength of the samples is preserved after $\gamma$-irradiation with a dose of $10 \mathrm{kGy}$ and after 30 cycles of freezing-thawing. The visual inspection of irradiated samples of mechanical fracture marks in the form of chips and cracks and color changes did not reveal. The normalized leaching rate of $10^{-3} \mathrm{~g} /\left(\mathrm{cm}^{2} \cdot \mathrm{d}\right)$ is achieved on $107 \div 446$ days.

The equations that associate the masses of imitate, water, cement and bentonite salts with the term of the beginning of gripping, the limit of compressive strength and the time of reaching the normalized value during leaching are obtained. The equations allow taking into account the change in the values of the parameters when optimizing the relations between the components.

Keywords: radioactivity, radiation firmness, speed of lixiviating, speed of consolidation, mechanical durability.

\section{References}

1. Kozlov P. V., Slyunchev O. M., Kiryanov K. V. (2011) [Cementing of bottoms of nuclear power plants with the placement of the compound in bulk storages]. Atomnaya energiya [Atomic energy], vol. 111, no. 3, pp. 148-154. (in Russ.)

2. Kozlov P. V., Slyunchev O. M , Smooth S. I. (2009) [Cementation as a method of solidifying liquid radioactive waste]. Tsement $i$ yego primeneniye [Cement and its application], vol. 6, pp. 67-72. (in Russ.)

3. Ershov B. G., Yurik T. K. (2008) [Immobilization of medium and high level waste in the cement matrix: the effect of irradiation on the formation of gases and leaching of radionuclides]. Voprosy radiatsionnoy bezopasnosti [Radiation Safety Issues], no. 1, pp. 3-15. (in Russ.)

4. Maslov M. V., Gupalo B. C., Chistyakov V. N. (2012) [Investigation of schemes for the management of accumu- lated radioactive waste in order to prepare them for final isolation]. Gornyi informatsionno analiticheskiy byulleten' [Mining Information Analytical Bulletin], no. 1, pp. 160164. (in Russ.)

5. [Rostov NPP operates an installation for liquid radioactive waste cementation] (17.05.2013) EnergyLand. info. Available at: http://www.energyland.info/analitic-show-104136. (in Russ.)

6. $\mathrm{RD}$ 306.4.098-2004. Recommendations on the establishment of criteria for the acceptance of conditioned radioactive waste for disposal in near-surface storage facilities. Approved by order of the State Nuclear Regulatory Committee of Ukraine from the no. 160, dated 25.10.2004. (in Ukr.)

7. Criteria for the acceptance of radioactive waste for disposal in a specially equipped near-surface storage facility for solid radioactive waste (SOPSTRV). The first stage of operation of SOPSTRV. Acceptance of radioactive waste from ZPPRW and ZPTRW of ChNPP for disposal in two symmetric compartments of SOPSTRV. Chornobyl, 2009, 38 p. (in Russ.)

8. GOST R 51883-2002. Waste radioactive cemented. General technical requirements. Moscow, IPK Publishing house of standards, 2002, 7 p. (in Russ.)

9. Novik F. S., Arsov Ya. B. (1980) Optimizatsiya protsessov tekhnologii metallov metodami planirovaniya eksperimentov [Optimization of metal technology processes using experimental planning methods]. Moscow: Mechanical Engineering; Sofia: Technique, 304 p. (in Russ.)

10. ASTM C293/C293M-10. Standard Test Method for Flexural Strength of Concrete (Using Simple Beam With Center-Point Loading). ASTM International, West Conshohocken, PA, 2010. doi: 10.1520/C0293_C0293M-10.

11. SOU YaEK 1.037: 2013. Short-lived low- and intermediate-level waste of NPPs. Requirements for the final processing product. Approved by the order of the Ministry of Energy and Coal Industry of Ukraine dated October 28, 2013, no. 790. Kyiv, 2013. (in Ukr.)
Надійшла 04.03.2019

Received 04.03.2019 


\author{
А. М. Максименко ${ }^{1}$, М. Д. Бондарьков ${ }^{1}$, Б. Я. Осколков ${ }^{1}$, В. А. Сейда ${ }^{2}$, В. Н. Дубас \\ ${ }^{1}$ ГНИУ «Чернобыльский иентр по проблемам ядерной безопасности, радиоактивных отходов и радиоэкологии», \\ ул. 77-й Гвардейской Дивизии, 11, г. Славутич, а/я 151, 07101, Украина

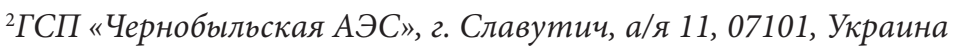

\title{
Результаты исследований трудноизмеряемых радионуклидов в металле демонтируемого оборудования Чернобыльской АЭС и оценка коэффициентов масштабирования
}

\author{
Ключевые слова: \\ Чернобыльская атомная \\ электростанция, \\ коэффициент масштабирования, \\ трудноизмеряемый радионуклид, \\ удельная активность, \\ радиоактивные отходы, \\ освобождение от регулирующего \\ контроля.
}

Представлены результаты исследований трудноизмеряемых радионуклидов ${ }^{55} \mathrm{Fe}$, ${ }^{59} \mathrm{Ni},{ }^{63} \mathrm{Ni},{ }^{90} \mathrm{Sr},{ }^{239},{ }^{240} \mathrm{Pu},{ }^{238} \mathrm{Pu},{ }^{241} \mathrm{Pu},{ }^{241} \mathrm{Am},{ }^{234} \mathrm{U},{ }^{235,},{ }^{236} \mathrm{U},{ }^{238} \mathrm{U}$ поверхностного загрязнения металла демонтируемого оборудования Чернобыльской атомной электростанции. Даны оценки коэффициентов масштабирования для трудноизмеряемых радионуклидов.

\section{Введение}

В процессе снятия Чернобыльской атомной электростанции (ЧАЭС) с эксплуатации демонтируется большое количество оборудования, металл которого имеет только поверхностное радиоактивное загрязнение. При условии успешной дезактивации данного металла возможно снятие с него регулирующего контроля путем прекращения [1]. Исследование всего объема демонтируемого металла на предмет содержания трудноизмеряемых радионуклидов (ТИРН) является задачей сложной и дорогостоящей. Снижение затрат на измерение удельной активности ТИРН возможно путем измерения ключевых радионуклидов с последующим расчетом ТИРН по эмпирическим коэффициентам масштабирования (КМ) [2, 3].

Основными целями данной работы были определение активности ключевых радионуклидов (КРН) и ТИРН в слое поверхностного загрязнения дезактивированного металла и расчет соответствующих КМ.
Для достижения поставленных целей необходимо было решить задачу по измерению удельной активности КРН и ТИРН на уровнях ниже установленных критериев освобождения [1].

Данные исследования проведены по заказу ГСП «Чернобыльская АЭС», основные результаты представлены в отчете о научно-исследовательской работе [4].

\section{Объекты исследования}

В рамках данной работы были исследованы фрагменты демонтированного теплообменного оборудования блока № 1 ЧАЭС: фрагмент паропровода на второй ступени сепаратора-пароперегревателя (СПП); жалюзи СПП; фрагмент корпуса теплообменника бойлера промышленного контура теплосети (БПТ); трубки конденсатора турбин.

После демонтажа оборудования в машинном зале первой очереди ЧАЭС в соответствии с техническим заданием ЧАЭС [5] проводилась его фрагментация и дезактивация.

() А. М. Максименко, М. Д. Бондарьков, Б. Я. Осколков, В. А. Сейда, В. Н. Дубас, 2019 
Материальный состав фрагментов оборудования, выбранного для проведения исследований, представлен в табл. 1.

Таблица 1. Материальный состав фрагментов оборудования, выбранного для проведения исследований

\begin{tabular}{|c|c|}
\hline Наименование & Название сплава \\
\hline Фрагмент СПП & Нержавеющая сталь 0Х18Н10Т \\
\hline $\begin{array}{c}\text { Жалюзи сепаратора- } \\
\text { пароперегревателя }\end{array}$ & Нержавеющая сталь 0Х18Н10Т \\
\hline $\begin{array}{c}\text { Фрагмент корпуса } \\
\text { БПТ }\end{array}$ & Углеродистая сталь \\
\hline $\begin{array}{c}\text { Трубки конденсатора } \\
\text { турбин }\end{array}$ & $\begin{array}{c}\text { Медно-никелевый сплав } \\
\text { (МНЖ-5-1) }\end{array}$ \\
\hline
\end{tabular}

\section{История формирования радиоактивного загрязнения объектов исследования}

Радиоактивное загрязнение объектов исследования обусловлено активированными коррозионными отложениями на внутренней поверхности трубопроводов [6]. Кроме среды теплоносителя КМПЦ, трубки конденсатора турбин контактировали c охлаждающей водой пруда-охладителя, что в условиях ЧАЭС в послеаварийный период приводило к дополнительному радиоактивному загрязнению, не свойственному для нормальной эксплуатации (наличие аварийных радионуклидов).

Формирование первичного радиоактивного загрязнения объектов исследования началось с пуском блока № 1 ЧАЭС (1977 г.) и продолжалось до его останова (1996 г.). За этот период произошли две радиационные аварии [7-9], которые могли значительно изменить радионуклидные соотношения поверхностного загрязнения объектов исследования путем привнесения в его состав продуктов деления и трансурановых элементов в количестве, не характерном для режима нормальной эксплуатации РБМК-1 [10].

Вотдельных случаях при превышении критериев радиационного контроля [11] производилась дополнительная абразивная дезактивация, которая могла привести к изменению соотношений радионуклидов, являющихся предметом настоящего исследования.

\section{Отбор проб}

Учитывая низкие уровни радиоактивного загрязнения, характерные для поверхностей дезак- тивированного металла, для получения численных значений результатов измерений удельной активности радионуклидов отбор проб металла производился в точках с максимальными уровнями общего поверхностного радиоактивного загрязнения. Если перепад значений радиоактивного загрязнения на поверхности объекта исследования не превышал $30 \%$, то точки для отбора проб намечали равномерно по поверхности объекта. От каждого объек-та исследований отбирали по пять точечных проб металла. В намеченной точке фрагмент металла вырезали, маркировали и упаковывали. Аналитический материал (поверхностное радиоактивное загрязнение) для измерения удельной активности радионуклидов снимали со всей поверхности точечной пробыметалла. Этуоперациюосуществлялив в лабораторных условиях. Для снятия использовали радиационно чистые ручные режущие инструменты. Поверхностный слой срезали до чистого металла, который имеет характерный металлический блеск. Глубина снятия составляла 0,1-0,3 мм. Для контроля полноты снятия поверхностного загрязнения определялась удельная активность ${ }^{137} \mathrm{Cs}$ в слое чистого металла. Данный метод отбора поверхностного слоя металла отличается своей трудоемкостью. В среднем отбор одной пробы занимает одну восьмичасовую рабочую смену. Однако применение электромеханических режущих инструментов или электрохимических методов могло привести к неконтролируемым потерям отдельных радионуклидов за счет повышения температуры и газообразования, и как следствие - приводить к изменению соотношений радионуклидов.

Отобранный аналитический материал представлял собой смесь оксидов металлов и металлической стружки.

\section{Методики измерения}

Измерения проводились в четыре этапа:

1) подготовка счетного образца и измерение активности гамма-излучающих радионуклидов, включая ключевые радионуклиды ${ }^{60} \mathrm{Co}$ и ${ }^{137} \mathrm{Cs}$;

2) растворение счетного образца после гаммаспектрометрии в смеси азотной и соляной кислот и отбор аликвоты для радиохимического анализа ${ }^{55} \mathrm{Fe}$, ${ }^{59} \mathrm{Ni},{ }^{63} \mathrm{Ni}$;

3) отбор аликвоты для радиохимического анализа ${ }^{239,240} \mathrm{Pu},{ }^{238} \mathrm{Pu},{ }^{241} \mathrm{Pu},{ }^{241} \mathrm{Am},{ }^{234} \mathrm{U},{ }^{235,236} \mathrm{U},{ }^{238} \mathrm{U}$;

4) отбор навески аналитического материала и определение активности ${ }^{10} \mathrm{Be}$. 


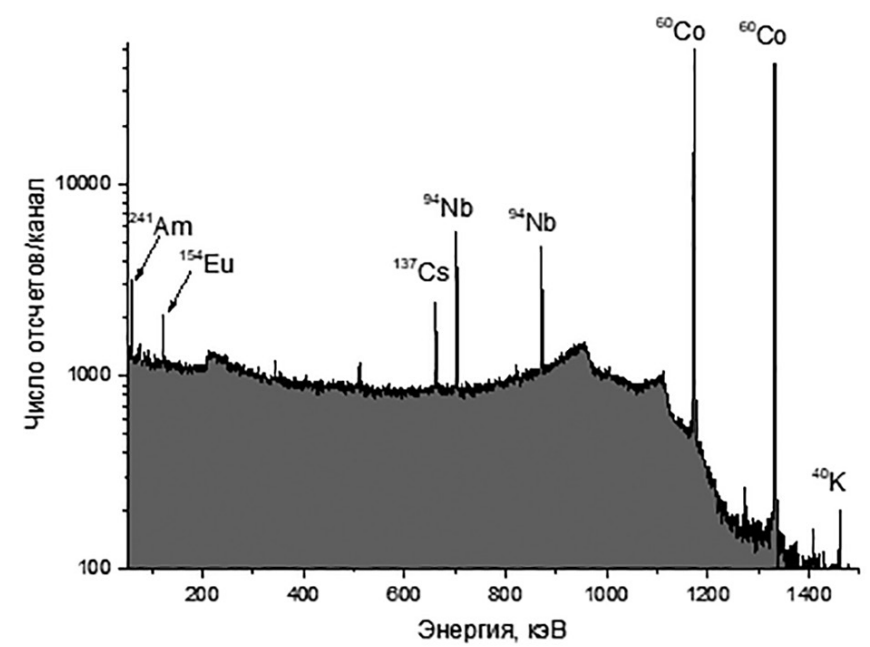

Рис. 1. Фрагмент энергетического спектра, полученного на детекторе GC3019 от пробы № ЖСП 3.

Время измерения 82917 с

Активность гамма-излучающих радионуклидов измеряли на спектрометре производства CANBER$\mathrm{RA}$ с полупроводниковым блоком детектирования GC3019. Для измерения навеску аналитического материала помещали в пластиковую чашку Петри с внешним диаметром 36 мм и толщиной стенки 0,7 мм. Пример спектра приведен на рис. 1.

Для калибровки спектрометра по эффективности использовали радионуклидный источник метрологического назначения типа ОИСН-1 [12] с радионуклидами ${ }^{152} \mathrm{Eu},{ }^{137} \mathrm{Cs},{ }^{44} \mathrm{Ti}$. В наиболее активных образцах на спектрометре с детектором GC3019 были измерены активности радионуклидов: ${ }^{40} \mathrm{~K},{ }^{60} \mathrm{Co},{ }^{94} \mathrm{Nb},{ }^{137} \mathrm{Cs},{ }^{154} \mathrm{Eu},{ }^{241} \mathrm{Am}$.

После измерения и обработки результатов гамма-спектрометрического анализа для проведения радиохимического анализа ТИРН часть счетного образца растворяли в смеси кислот $\mathrm{HCl}$ и $\mathrm{HNO}_{3}$ (1:1) [13].

Радиохимический анализ ${ }^{55} \mathrm{Fe},{ }^{59} \mathrm{Ni},{ }^{63} \mathrm{Ni}$ проводили по ранее разработанной методике, представленной в отчете о научно-исследовательской работе [14].

Активность ${ }^{55} \mathrm{Fe}$ и ${ }^{59} \mathrm{Ni}$ в подготовленных счетных образцах измеряли на низкоэнергетическом германиевом детекторе GL0520R фирмы CANBERRA. Примеры полученных энергетических спектров ${ }^{55} \mathrm{Fe}$ и ${ }^{59} \mathrm{Ni}$ представлены на рис. 2 и 3 соответственно.

После измерения активности ${ }^{59} \mathrm{Ni}$ счетный образец никеля помещали в стеклянный сцинтилляционный флакон объемом 20 мл и растворяли осадок

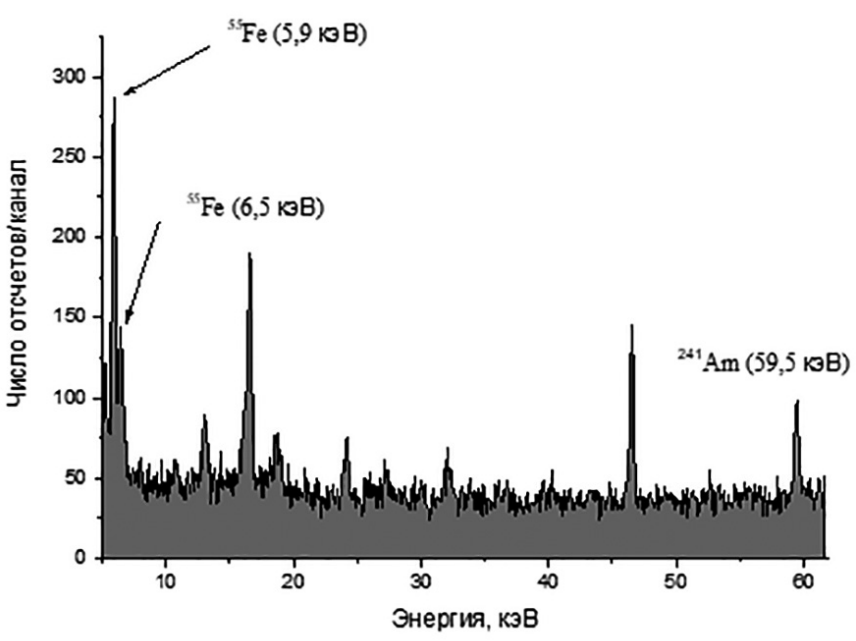

Рис. 2. Фрагмент энергетического спектра, полученного на детекторе GL0520R от счетного образца ${ }^{55} \mathrm{Fe}$ пробы № ЖСП 3. Время измерения 352891 с

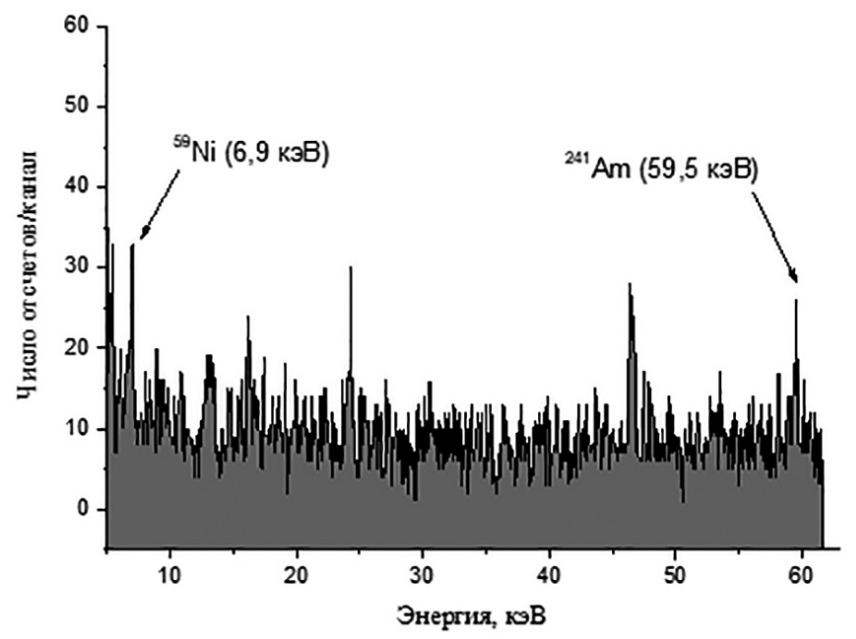

Рис. 3. Фрагмент энергетического спектра, полученного на детекторе GL0520R от счетного образца ${ }^{59+63} \mathrm{Ni}$ пробы № ЖСП 3. Время измерения 82773 с

$\mathrm{Ni}(\mathrm{DMG})_{2}$ в 1 мл водного раствора соляной кислоты с молярной концентрацией 0,5 моль $\cdot$ дм $^{-3}$. К полученному раствору добавляли 14 мл сцинтилляционного коктейля Ultima Gold AB и измеряли активность ${ }^{63} \mathrm{Ni}$ по его бета-излучению на жидкостном сцинтилляционном анализаторе TRI-CARB 2500TR. Примеры спектров ${ }^{63} \mathrm{Ni}$, полученные на TRI-CARB 2500TR, показаны на рис. 4.

Радиохимический анализ ${ }^{90} \mathrm{Sr},{ }^{239,}{ }^{240} \mathrm{Pu},{ }^{238} \mathrm{Pu},{ }^{241} \mathrm{Pu}$, ${ }^{241} \mathrm{Am},{ }^{234} \mathrm{U},{ }^{235,}{ }^{236} \mathrm{U},{ }^{238} \mathrm{U}$ проводили по адаптированной для данного типа образцов методике [15]. 


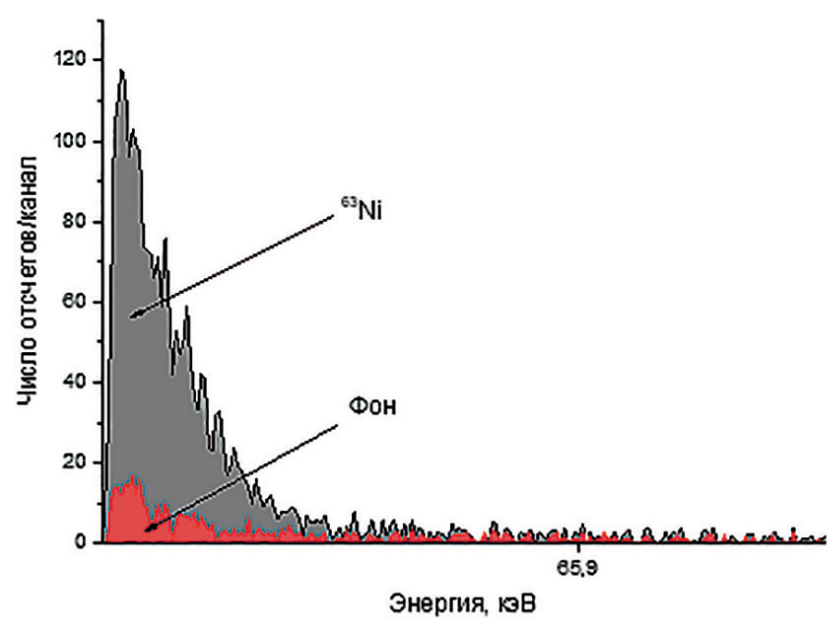

Рис. 4. Бета-спектр ${ }^{63} \mathrm{Ni}$ пробы № ЖСП 3 и спектр фона. Время измерения пробы равнялось времени измерения фона - 1200 с

Счетные образцы для измерения ${ }^{90} \mathrm{Sr}$ готовили в виде оксалата стронция, нанесенного на бумажный фильтр. Коэффициент химического выхода стронция определяли гравиметрическим методом. Активность счетного образца ${ }^{90} \mathrm{Sr}$ измеряли на газо-проточном низкофоновом пропорциональном счетчике [16].

Коэффициент химического выхода урана определяли по внесенному трассеру ${ }^{232} \mathrm{U}$. Альфаспектрометрические счетные образцы урана готовили методом электролиза [17]. Активность счетного образца измеряли на альфа-спектрометре с пассивированными ионно-имплантированными планарными кремниевыми детекторами. Пример альфа-спектра изотопов урана представлен на рис. 5.

Коэффициент химического выхода плутония определяли по внесенному трассеру ${ }^{242} \mathrm{Pu}$. Альфаспектрометрические образцы для измерения изотопов плутония готовили осаждением плутония в форме $\mathrm{Pu} / \mathrm{NdF}_{3}$ на мембраны с диаметром пор 0,1 мкм [18]. Активность счетного образца измеряли на альфа-спектрометре с пассивированными ионноимплантированными планарными кремниевыми детекторами. Пример альфа-спектра изотопов плутония представлен на рис. 6.

Активность ${ }^{241} \mathrm{Pu}$ измеряли по его бетаизлучению на жидкостном сцинтилляционном спектрометре (ЖСС). Для этого альфа-спектрометрический счетный образец после измерения и расчета активности альфа-излучающих изотопов плутония помещали в сцинтилляционный флакон и

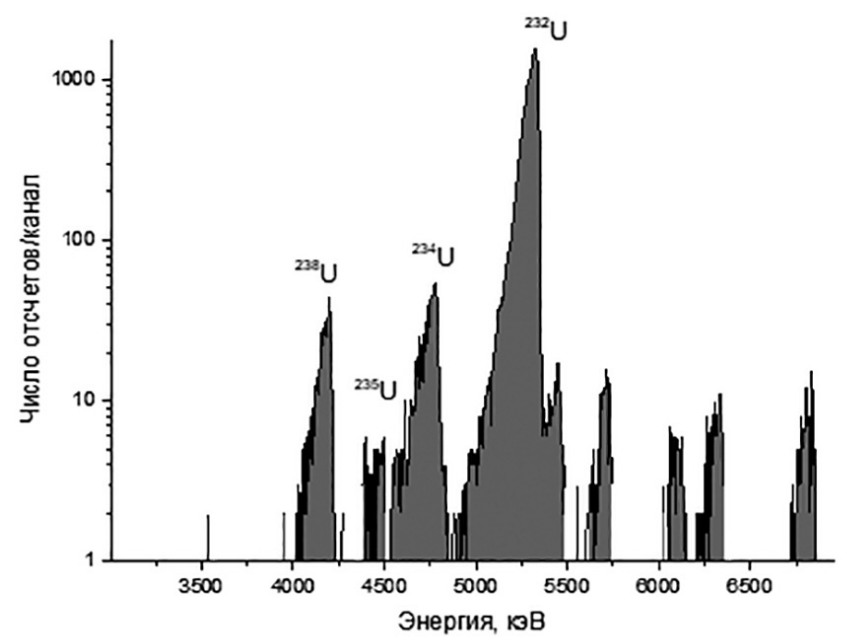

Рис. 5. Альфа-спектр изотопов урана, измеренный в пробе № ЖСП 3. Время измерения пробы 1254593 с

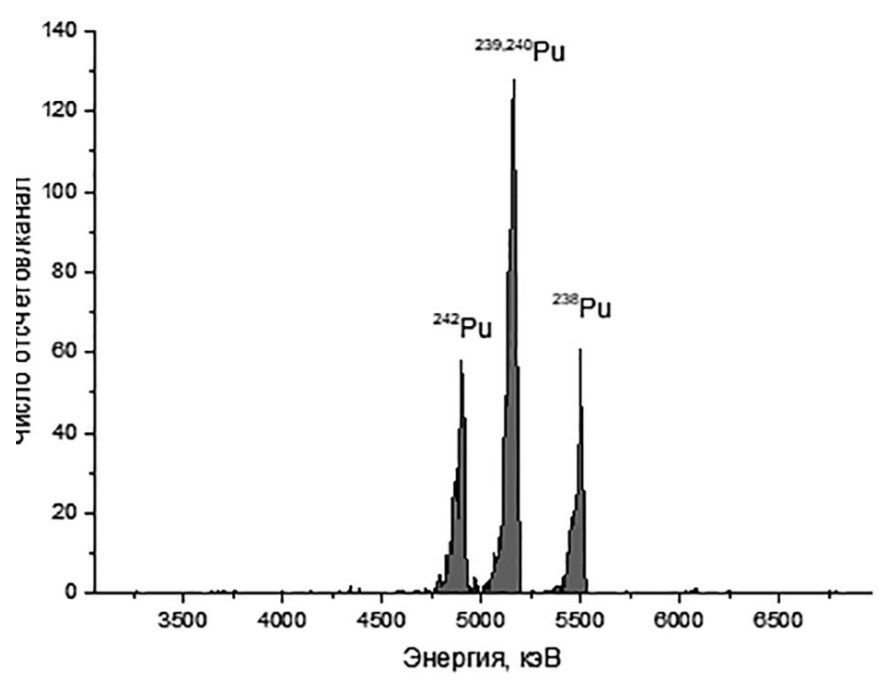

Рис. 6. Альфа-спектр изотопов плутония, измеренный в пробе № ЖСП 3. Время измерения пробы 69075 с

готовили счетный образец для измерения на ЖСС, как это описано в [15].

Коэффициент химического выхода америция и кюрия определяли по внесенному в пробу трассеру ${ }^{243} \mathrm{Am}$. Альфа-спектрометрические образцы для измерения изотопов америция и кюрия готовили методом электролиза [17]. Активность счетного образца измеряли на альфа-спектрометре с пассивированными ионно-имплантированными планарными кремниевыми детекторами. Пример альфа-спектра изотопов америция и кюрия представлен на рис. 7. 


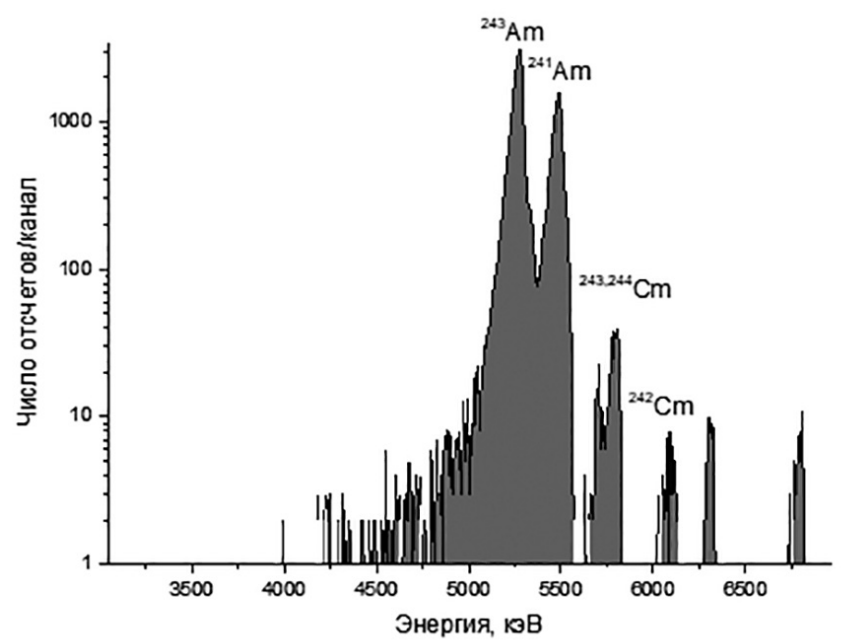

Рис. 7. Альфа-спектр изотопов америция и кюрия, измеренный в пробе № ЖСП З. Время измерения пробы 192191 с

\section{Активность радионуклидов в объектах исследований}

Результаты измерений удельной активности радионуклидов, обнаруженных в отобранных пробах, представлены в табл. 2 и 3 [4]. Суммарная погрешность результатов измерений, указанных в табл. 2 и 3, не превышает 50 \% для доверительной вероятности 0,95.

\section{Ключевые радионуклиды}

Основываясь на критериях отнесения радионуклидов к ключевым [2], из перечисленных в табл. 2 и 3 в качестве таковых могут рассматриваться ${ }^{60}$ Со и ${ }^{137} \mathrm{Cs}$. Рассчитанные коэффициенты корреляции между этими радионуклидами и некоторыми из ТИРН составляют следующие величины: ${ }^{60} \mathrm{Co}-{ }^{63} \mathrm{Ni}-0,60$; ${ }^{137} \mathrm{Cs}-{ }^{90} \mathrm{Sr}-0,44 ;{ }^{137} \mathrm{Cs}-{ }^{239,}{ }^{240} \mathrm{Pu}-0,61 ;{ }^{137} \mathrm{Cs}-{ }^{241} \mathrm{Pu}-0,64$; ${ }^{137} \mathrm{Cs}-{ }^{241} \mathrm{Am}-0,66$.

\section{Парциальный вклад радионуклидов в суммарную активность и коэффициенты масштабирования}

Значения парциального вклада рассчитаны как соотношение медианного значения удельной активности радионуклида к сумме удельных активностей радионуклидов. Значение коэффициента масштабирования рассчитано как отношение медианного значения радионуклида к медианному значению ключевого радионуклида. Полученные величины представлены в табл. 4.

Таблица 2. Результаты измерений удельной активности радионуклидов в пробах металла корпуса теплообменика и жалюзи, Бк/г

\begin{tabular}{|c|c|c|c|c|c|c|c|c|c|c|}
\hline \multirow{2}{*}{$\mathrm{PH}^{*}$} & \multicolumn{5}{|c|}{ Корпус теплообменника } & \multicolumn{5}{|c|}{ Жалюзи } \\
\hline & 1 & 2 & 3 & 4 & 5 & 1 & 2 & 3 & 4 & 5 \\
\hline${ }^{40} \mathrm{~K}$ & $6,7 \mathrm{E}-02$ & $3,6 \mathrm{E}-02$ & $<0,1$ & $8,1 \mathrm{E}-02$ & $6,8 \mathrm{E}-02$ & $2,7 \mathrm{E}-01$ & $1,3 \mathrm{E}-01$ & $3,5 \mathrm{E}-01$ & $1,0 \mathrm{E}-01$ & $1,9 \mathrm{E}-01$ \\
\hline${ }^{60} \mathrm{Co}$ & $3,5 \mathrm{E}+00$ & $2,9 \mathrm{E}+00$ & $3,5 \mathrm{E}+00$ & $4,6 \mathrm{E}+00$ & $2,3 \mathrm{E}+00$ & $2,0 \mathrm{E}+01$ & $2,5 \mathrm{E}+01$ & $5,3 \mathrm{E}+01$ & $3,4 \mathrm{E}+01$ & $3,9 \mathrm{E}+01$ \\
\hline${ }^{90} \mathrm{Sr}$ & $4,3 \mathrm{E}-02$ & $6,3 \mathrm{E}-02$ & $3,0 \mathrm{E}-02$ & $6,4 \mathrm{E}-02$ & $2,1 \mathrm{E}-02$ & $1,1 \mathrm{E}-01$ & $1,6 \mathrm{E}-01$ & $1,1 \mathrm{E}+00$ & $3,7 \mathrm{E}-01$ & $8,7 \mathrm{E}-01$ \\
\hline${ }^{94} \mathrm{Nb}$ & 7,9E-03 & $1,8 \mathrm{E}-02$ & $1,1 \mathrm{E}-02$ & $1,6 \mathrm{E}-02$ & $<0,013$ & $6,5 \mathrm{E}-01$ & $6,4 \mathrm{E}-01$ & $2,6 \mathrm{E}+00$ & $1,5 \mathrm{E}+00$ & $1,6 \mathrm{E}+00$ \\
\hline${ }^{137} \mathrm{Cs}$ & $3,6 \mathrm{E}-02$ & $3,6 \mathrm{E}-02$ & $3,1 \mathrm{E}-02$ & $9,2 \mathrm{E}-02$ & $4,1 \mathrm{E}-02$ & $3,5 \mathrm{E}-01$ & $4,0 \mathrm{E}-01$ & $9,0 \mathrm{E}-01$ & $1,4 \mathrm{E}+00$ & $8,0 \mathrm{E}-01$ \\
\hline${ }^{154} \mathrm{Eu}$ & $<0,017$ & $<0,01$ & $<0,01$ & $<0,016$ & $<0,008$ & $1,0 \mathrm{E}-01$ & $1,8 \mathrm{E}-01$ & 2,7E-01 & $1,4 \mathrm{E}-01$ & $2,5 \mathrm{E}-01$ \\
\hline${ }^{239,}{ }^{240} \mathrm{Pu}$ & $3,3 \mathrm{E}-02$ & 1,9E-02 & $8,2 \mathrm{E}-02$ & 4,7E-02 & $1,3 \mathrm{E}-02$ & $1,2 \mathrm{E}-01$ & 1,7E-01 & $5,3 \mathrm{E}-01$ & $3,3 \mathrm{E}-01$ & 3,7E-01 \\
\hline${ }^{238} \mathrm{Pu}$ & $1,1 \mathrm{E}-02$ & $8,5 \mathrm{E}-03$ & $1,6 \mathrm{E}-02$ & $1,2 \mathrm{E}-02$ & $3,0 \mathrm{E}-03$ & $4,5 \mathrm{E}-02$ & $5,6 \mathrm{E}-02$ & 1,7E-01 & $1,2 \mathrm{E}-01$ & $1,2 \mathrm{E}-01$ \\
\hline${ }^{241} \mathrm{Pu}$ & $3,4 \mathrm{E}-01$ & $1,8 \mathrm{E}-01$ & $2,3 \mathrm{E}-01$ & 2,9E-01 & $3,3 \mathrm{E}-01$ & $1,6 \mathrm{E}+00$ & $1,7 \mathrm{E}+00$ & $6,2 \mathrm{E}+00$ & $4,0 \mathrm{E}+00$ & $4,4 \mathrm{E}+00$ \\
\hline${ }^{241} \mathrm{Am}$ & $2,3 \mathrm{E}-02$ & $3,1 \mathrm{E}-02$ & $2,3 \mathrm{E}-02$ & $3,3 \mathrm{E}-02$ & $5,9 \mathrm{E}-03$ & $2,5 \mathrm{E}-01$ & $4,0 \mathrm{E}-01$ & $1,0 \mathrm{E}+00$ & $6,8 \mathrm{E}-01$ & $7,4 \mathrm{E}-01$ \\
\hline${ }^{234} \mathrm{U}$ & $2,2 \mathrm{E}-02$ & $1,4 \mathrm{E}-03$ & $5,4 \mathrm{E}-03$ & $1,2 \mathrm{E}-03$ & $1,1 \mathrm{E}-03$ & $1,3 \mathrm{E}-02$ & $1,6 \mathrm{E}-02$ & 1,9E-02 & 1,7E-02 & $3,1 \mathrm{E}-02$ \\
\hline${ }^{235,236} \mathrm{U}$ & $<0,000026$ & $<0,000014$ & $<0,000014$ & $<0,000010$ & $<0,000018$ & $<0,000030$ & $1,6 \mathrm{E}-03$ & $1,8 \mathrm{E}-03$ & $1,1 \mathrm{E}-03$ & $<0,000026$ \\
\hline${ }^{238} \mathrm{U}$ & $1,3 \mathrm{E}-02$ & $6,3 \mathrm{E}-04$ & $3,0 \mathrm{E}-03$ & $3,9 \mathrm{E}-04$ & 8,9E-04 & $6,6 \mathrm{E}-03$ & $8,6 \mathrm{E}-03$ & $1,1 \mathrm{E}-02$ & $9,2 \mathrm{E}-03$ & $1,2 \mathrm{E}-02$ \\
\hline${ }^{59} \mathrm{Ni}$ & $<0,706$ & $<0,716$ & $<0,624$ & $<0,591$ & $<0,653$ & $<0,932$ & 5,6E-01 & $4,6 \mathrm{E}-01$ & $<1,672$ & 7,1E-01 \\
\hline${ }^{63} \mathrm{Ni}$ & $2,2 \mathrm{E}+00$ & $<2,152$ & $2,9 \mathrm{E}+00$ & $<2,108$ & $<1,953$ & $1,4 \mathrm{E}+01$ & $2,5 \mathrm{E}+01$ & $2,7 \mathrm{E}+01$ & $6,4 \mathrm{E}+01$ & $4,3 \mathrm{E}+01$ \\
\hline${ }^{55} \mathrm{Fe}$ & $<0,926$ & $<0,676$ & $<0,794$ & $<0,632$ & $<0,630$ & $2,8 \mathrm{E}+00$ & $9,1 \mathrm{E}+00$ & $3,2 \mathrm{E}+00$ & $9,9 \mathrm{E}+00$ & $7,1 \mathrm{E}+00$ \\
\hline
\end{tabular}

*PН - радионуклиды 
Таблица 3. Результаты измерений удельной активности радионуклидов в пробах металла МНЖ трубки и трубопровода СПП, Бк/г

\begin{tabular}{|c|c|c|c|c|c|c|c|c|c|c|}
\hline \multirow{2}{*}{$\mathrm{PH}$} & \multicolumn{5}{|c|}{ МНЖ трубки } & \multicolumn{5}{|c|}{ Трубопровод СПП } \\
\hline & 1 & 2 & 3 & 4 & 5 & 1 & 2 & 3 & 4 & 5 \\
\hline${ }^{40} \mathrm{~K}$ & $1,2 \mathrm{E}-01$ & $<0,11$ & $<0,18$ & $<0,184$ & $<0,17$ & $1,4 \mathrm{E}-01$ & $<0,224$ & $<0,26$ & $<0,23$ & $<0,25$ \\
\hline${ }^{60} \mathrm{Co}$ & $7,2 \mathrm{E}-02$ & $3,8 \mathrm{E}-02$ & $6,6 \mathrm{E}-02$ & $7,3 \mathrm{E}-01$ & $1,3 \mathrm{E}-01$ & $2,6 \mathrm{E}-01$ & $4,9 \mathrm{E}-02$ & $3,7 \mathrm{E}+00$ & $5,0 \mathrm{E}-01$ & $3,5 \mathrm{E}+00$ \\
\hline${ }^{90} \mathrm{Sr}$ & $<0,050$ & $4,8 \mathrm{E}-01$ & $4,2 \mathrm{E}-01$ & $1,4 \mathrm{E}-01$ & $1,3 \mathrm{E}-01$ & $1,6 \mathrm{E}-01$ & $2,5 \mathrm{E}-01$ & $5,4 \mathrm{E}-01$ & $2,4 \mathrm{E}-01$ & $1,6 \mathrm{E}+00$ \\
\hline${ }^{94} \mathrm{Nb}$ & $4,0 \mathrm{E}-03$ & $2,3 \mathrm{E}-03$ & $4,0 \mathrm{E}-03$ & $2,8 \mathrm{E}-02$ & $8,7 \mathrm{E}-03$ & $<0,018$ & $3,9 \mathrm{E}-03$ & $1,1 \mathrm{E}-01$ & $6,2 \mathrm{E}-02$ & 9,7E-02 \\
\hline${ }^{137} \mathrm{Cs}$ & $1,1 \mathrm{E}-01$ & $8,7 \mathrm{E}-01$ & $6,4 \mathrm{E}-01$ & $7,2 \mathrm{E}-01$ & $7,2 \mathrm{E}-01$ & $1,5 \mathrm{E}-01$ & $2,5 \mathrm{E}-01$ & $2,9 \mathrm{E}-01$ & $3,1 \mathrm{E}-01$ & $5,3 \mathrm{E}-01$ \\
\hline${ }^{154} \mathrm{Eu}$ & $<0,007$ & $<0,008$ & $<0,0148$ & $<0,012$ & $<0,0106$ & $<0,021$ & 2,3E-02 & $6,6 \mathrm{E}-02$ & $<0,014$ & 4,9E-02 \\
\hline${ }^{239,240} \mathrm{Pu}$ & $5,0 \mathrm{E}-03$ & $4,1 \mathrm{E}-03$ & 4,7E-03 & $1,5 \mathrm{E}-02$ & $2,3 \mathrm{E}-01$ & $1,1 \mathrm{E}-02$ & $4,1 \mathrm{E}-02$ & $1,5 \mathrm{E}-01$ & $1,8 \mathrm{E}-01$ & $9,0 \mathrm{E}-02$ \\
\hline${ }^{238} \mathrm{Pu}$ & $2,7 \mathrm{E}-03$ & $2,3 \mathrm{E}-03$ & 2,9E-03 & $7,1 \mathrm{E}-03$ & $9,5 \mathrm{E}-02$ & $6,3 \mathrm{E}-03$ & $1,8 \mathrm{E}-02$ & $6,8 \mathrm{E}-02$ & $6,0 \mathrm{E}-02$ & 4,4E-02 \\
\hline${ }^{241} \mathrm{Pu}$ & $1,6 \mathrm{E}-01$ & $1,3 \mathrm{E}-01$ & $1,1 \mathrm{E}-01$ & $3,1 \mathrm{E}-01$ & $3,2 \mathrm{E}+00$ & $1,3 \mathrm{E}-01$ & $6,8 \mathrm{E}-01$ & $2,9 \mathrm{E}+00$ & $6,1 \mathrm{E}-01$ & $1,4 \mathrm{E}+00$ \\
\hline${ }^{241} \mathrm{Am}$ & $3,7 \mathrm{E}-02$ & 7,7E-03 & $6,0 \mathrm{E}-03$ & $2,9 \mathrm{E}-02$ & $2,7 \mathrm{E}-01$ & $2,4 \mathrm{E}-02$ & $7,0 \mathrm{E}-02$ & $2,4 \mathrm{E}-01$ & $2,9 \mathrm{E}-02$ & $1,2 \mathrm{E}-01$ \\
\hline${ }^{234} \mathrm{U}$ & $7,2 \mathrm{E}-03$ & 3,3E-03 & $1,4 \mathrm{E}-03$ & $2,8 \mathrm{E}-03$ & $2,5 \mathrm{E}-03$ & $2,8 \mathrm{E}-03$ & 1,7E-03 & $1,4 \mathrm{E}-03$ & 4,4E-03 & 4,4E-03 \\
\hline${ }^{235,}{ }^{236} \mathrm{U}$ & $<0,000013$ & $<0,000012$ & $<0,000012$ & $<0,000012$ & $<0,000039$ & $<0,000015$ & $<0,000099$ & $<0,000094$ & $<0,000011$ & $<0,000013$ \\
\hline${ }^{238} \mathrm{U}$ & $5,3 \mathrm{E}-03$ & 1,9E-03 & $1,1 \mathrm{E}-03$ & $1,8 \mathrm{E}-03$ & 2,7E-04 & 2,7E-03 & $2,3 \mathrm{E}-03$ & $2,5 \mathrm{E}-03$ & 3,9E-03 & $3,3 \mathrm{E}-03$ \\
\hline${ }^{59} \mathrm{Ni}$ & $<0,594$ & $<0,599$ & $<0,585$ & $<0,601$ & $<0,460$ & $<0,442$ & $<0,429$ & $<0,461$ & $<0,634$ & $<0,594$ \\
\hline${ }^{63} \mathrm{Ni}$ & $<2,115$ & $1,7 \mathrm{E}+00$ & $<2,022$ & $<1,977$ & $<1,957$ & $<2,088$ & $<1,965$ & $5,0 \mathrm{E}+00$ & $<1,947$ & $7,8 \mathrm{E}+00$ \\
\hline${ }^{55} \mathrm{Fe}$ & $<0,668$ & $<0,941$ & $<0,839$ & $1,1 \mathrm{E}+00$ & $<0,709$ & $<0,730$ & $<0,619$ & $<0,622$ & $<0,601$ & $<0,676$ \\
\hline
\end{tabular}

Таблица 4. Результаты расчета парциального вклада радионуклидов в суммарную активность и коэффициент масштабирования

\begin{tabular}{|c|c|c|c|c|c|}
\hline $\mathrm{PH}$ & $\begin{array}{c}\text { Количество } \\
\text { значений, } \\
\text { взятых для } \\
\text { расчета } \\
\text { медианы, n }\end{array}$ & \begin{tabular}{|c|} 
Медианное \\
значение удельной \\
активности \\
РН, Бк/г
\end{tabular} & $\begin{array}{c}\text { Парциальный } \\
\text { вклад РН } \\
\text { в суммарную } \\
\text { активность }\end{array}$ & $\begin{array}{c}\text { Коэффициент } \\
\text { масштабирования } \\
\text { РН } /{ }^{60} \text { Со и суммарная } \\
\text { неопределенность }\end{array}$ & $\begin{array}{c}\text { Коэффициент } \\
\text { масштабирования } \\
\text { РН/137Сs и суммарная } \\
\text { неопределенность }\end{array}$ \\
\hline${ }^{60} \mathrm{Co}$ & 21 & 2,860 & $13,81 \%$ & - & $8,171 \pm 214,10$ \\
\hline${ }^{90} \mathrm{Sr}$ & 20 & 0,163 & $0,79 \%$ & $0,057 \pm 1,63$ & $0,466 \pm 214,10$ \\
\hline${ }^{94} \mathrm{Nb}$ & 18 & 0,023 & $0,11 \%$ & $0,008 \pm 1,20$ & $0,065 \pm 9,70$ \\
\hline${ }^{137} \mathrm{Cs}$ & 21 & 0,350 & $1,69 \%$ & $0,122 \pm 1,20$ & - \\
\hline${ }^{154} \mathrm{Eu}$ & 8 & 0,119 & $0,57 \%$ & $0,041 \pm 1,20$ & $0,339 \pm 1,98$ \\
\hline${ }^{239}, 240 \mathrm{Pu}$ & 20 & 0,064 & $0,31 \%$ & $0,023 \pm 0,62$ & $0,184 \pm 1,98$ \\
\hline${ }^{238} \mathrm{Pu}$ & 20 & 0,017 & $0,08 \%$ & $0,006 \pm 0,62$ & $0,049 \pm 0,74$ \\
\hline${ }^{241} \mathrm{Pu}$ & 20 & 0,475 & $2,30 \%$ & $0,166 \pm 0,62$ & $1,358 \pm 0,74$ \\
\hline${ }^{241} \mathrm{Am}$ & 20 & 0,035 & $0,17 \%$ & $0,012 \pm 0,59$ & $0,100 \pm 4,17$ \\
\hline${ }^{238} \mathrm{U}$ & 20 & 0,003 & $0,01 \%$ & $0,001 \pm 0,03$ & $0,008 \pm 0,07$ \\
\hline${ }^{59} \mathrm{Ni}$ & 3 & 0,556 & $2,69 \%$ & $0,195 \pm 4,98$ & $1,589 \pm 0,07$ \\
\hline${ }^{63} \mathrm{Ni}$ & 10 & 10,866 & $52,48 \%$ & $3,799 \pm 99,92$ & $31,045 \pm 251,80$ \\
\hline${ }^{55} \mathrm{Fe}$ & 6 & 5,172 & $24,98 \%$ & $1,808 \pm 99,92$ & $14,778 \pm 84,61$ \\
\hline \multicolumn{2}{|c|}{ Суммарная активность, Бк/г } & 20,7 & - & - & - \\
\hline
\end{tabular}




\section{Выводы}

Использованные в данной работе подходы к отбору проб и методы измерения позволили с достаточной достоверностью определить активность ТИРН в пробах металла демонтируемого оборудования ЧАЭС и рассчитать для них КМ и их суммарные неопределенности, которые могут быть использованы в практике.

Большие значения суммарной неопределенности коэффициентов масштабирования обусловлены различиями в соотношениях радионуклидов радиоактивного загрязнения исследованных фрагментов оборудования, причиной которых может быть дифференцированное применение дезактивации (проводилась дезактивация только тех фрагментов, уровни загрязнения которых превышали установленные уровни).

Полученные результаты позволяют сделать вывод о том, что для определения КМ с целью освобождения от регулирующего контроля необходим тщательный подход к формированию потока PM, для которых применяется одинаковый способ дезактивации.

\section{Список использованной литературы}

1. НП 306.4.159-2010. Порядок звільнення радіоактивних матеріалів від регулюючого контролю у рамках практичної діяльності. [Прийнятий Наказом Державного комітету ядерного регулювання України від 01.04.2010 р. № 84, чинний від 06.09.2010р.]. Київ, 2010.

2. ISO 21238:2007. Nuclear Energy - Nuclear Fuel Technology - Scaling Factor Method to Determine the Radioactivity of Low- and Intermediate-level Radioactive Waste Packages Generated at Nuclear Power Plants / International Organization for Standardization, 2007. - 23 p.

3. Determination and Use of Scaling Factors for Waste Characterization in Nuclear Power Plants / International Atomic Energy Agency // IAEA Nuclear Energy Series. No. NW-T-1.18. - Vienna, 2009.

4. Выполнение измерений образцов металла оборудования, демонтируемого в машинном зале первой очереди ГСП ЧАЭС с последующим расчетом коэффициентов пропорциональности для трудноизмеряемых радионуклидов : отчет о НИР / ГНИУ «Чернобыльский центр по проблемам ядерной безопасности, радиоактивных отходов и радиоэкологии». - Славутич, 2016.

5. Технічне завдання на демонтаж, переробку, звіль- нення від регулюючого контролю обладнання та конструкцій машинної зали 1-го блоку ДСП ЧАЕС.

6. Герасимов В. В. Водный режим атомных станций / В. В. Герасимов, А. И. Касперович, О. И. Мартынова. М. : Атомиздат, 1976. - 400 c.

7. Чернобыльская катастрофа / Под ред. В. Г. Барьяхтара - Киев : Наук. думка, 1995. - 559 с.

8. Герасько В. Н. Объект «Укрытие». История, состояние и перспективы / В. Н. Герасько, А. А. Ключников, А. А. Корнеев и др. - Киев : Интерграфик, 1997. $224 \mathrm{c}$.

9. Доллежаль Н. А. Анализ причин и последствий аварийного разрыва канала 62-44 реактора блока № 1 Чернобыльской АЭС. Отчет 4.50. - М., 1983.

10. ТВС РБМК-1000. Техническое описание. 862.00.000 ТО.

11. Технологические радиационные критерии, 39Э-ЦРБ / ГСП «Чернобыльская АЭС». - 2016. - 22 с.

12. Паспорт № 01-0041-05 на радионуклидный источник метрологического назначения типа ОИСН с радионуклидами европий-152, цезий-137, титан-44. Государственное предприятие / Одесский научно-производственный центр экологической безопасности. Одесса, 2005.

13. Бок. Р. Методы разложения в аналитической химии / Р. Бок. - М. : Химия, 1984. - 432 с.

14. Определение радиоизотопного состава и активности специзделий в центральных залах блоков № 1, 2, 3, которые не подлежат переработке отходов ЛИД. Разработка методики измерения специзделий. Подготовка предложений относительно обращения с ними : отчет о НИР / М. Д. Бондарьков, А. М. Максименко, Б. Я. Осколков и др.; ГНИУ «Чернобыльский центр по проблемам ядерной безопасности, радиоактивных отходов и радиоэкологии». Славутич, 2013.

15. Vajda N. Simultaneous determination of long-lived radionunuclides in environmental samples / N. Vajda, Zs. Molnar, E. Kabai, Sz. Osvath // Environmental Radiochemical Analysis II. - 2003. - P. 185-196.

16. Operating Manual. FHT 770 T Multi-Low-LevelCounter for measurement of low level alpha and beta activity in samples up to $60 \mathrm{~mm}$ diameter. Eberline Instruments.

17. IAEA Analytical Quality in Nuclear Applications Series No. 37. A Procedure for the Sequential Determination of Radionuclides in Environmental Samples. - Vienna : International Atomic Enerбgy Agency, 2014.

18. IAEA Analytical Quality in Nuclear Applications No. IAEA/ AQ/11. A Procedure for the Rapid Determination of $\mathrm{Pu}$ Isotopes and Am-241 in Soil and Sediment Samples by Alpha Spectrometry. - Vienna : International Atomic Energy Agency, 2009.

19. Ампелегова Н. И. Дезактивация в ядерной энергетике / Н. И. Ампелегова, Ю. М. Симановский, А. А. Трапезников. - М. : Энергоиздат, 1982. - 256 с. 
А. М. Максименко ${ }^{1}$, М. Д. Бондарьков ${ }^{1}$, Б. Я. Осколков ${ }^{1}$, В. А. Сейда ${ }^{2}$, В. Н. Дубас

${ }^{1}$ ДНДУ «Чорнобильський иентр з проблем ядерної безпеки, радіоактивних відходів та радіоекологї», м. Славутич, a/c 151, 07101, Україна

${ }^{2}$ ДСП «Чорнобильська АЕС», м. Славутич, a/c 11, 07101, украйна

\section{Результати досліджень важковимірюваних радіонуклідів у металі обладнання Чорнобильської АЕС, що демонтується, і оцінка коефіцієнту масштабування}

Представлено результати досліджень важковимірюваних радіонуклідів ${ }^{55} \mathrm{Fe},{ }^{59} \mathrm{Ni},{ }^{63} \mathrm{Ni},{ }^{90} \mathrm{Sr},{ }^{239},{ }^{240} \mathrm{Pu},{ }^{238} \mathrm{Pu},{ }^{241} \mathrm{Pu}$, ${ }^{241} \mathrm{Am},{ }^{234} \mathrm{U},{ }^{235,}{ }^{236} \mathrm{U},{ }^{238} \mathrm{U}$ поверхневого забруднення металу обладнання Чорнобильської AEC, що демонтується. Дано оцінки коефіцієнтів масштабування для важковимірюваних радіонуклідів.

Ключові слова: Чорнобильська АЕС, коефіцієнт масштабування, важковимірюваний радіонуклід, питома активність, радіоактивні відходи, звільнення від регулюючого контролю.

\section{A. M., Maksymenko ${ }^{1}$, M. D. Bondarkov ${ }^{1}$, B. Ya. Oskolkov', V. A. Seida' ${ }^{2}$ V. N. Dubas ${ }^{2}$}

'SSRI "Chornobyl Center for Nuclear Safety, Radioactive Waste and Radioecology", Slavutych, 07101, Ukraine

${ }^{2}$ SSE “Chornobyl NPP”, Slavutych, 07101, Ukraine

\section{Results for Studies of Hard-to-Measure Radionuclides in the Metal of Chornobyl Nuclear Power Plant Equipment being Dismanlted, and Estimation of Scaling Factor}

The results of studies are presented for hard-to-measure radionuclides ${ }^{55} \mathrm{Fe},{ }^{59} \mathrm{Ni},{ }^{63} \mathrm{Ni},{ }^{90} \mathrm{Sr},{ }^{239}{ }^{240} \mathrm{Pu},{ }^{238} \mathrm{Pu},{ }^{241} \mathrm{Pu},{ }^{241} \mathrm{Am}$, ${ }^{234} \mathrm{U},{ }^{235},{ }^{236} \mathrm{U},{ }^{238} \mathrm{U}$ in the surface contamination of the metal of ChNPP equipment, being dismantled. The estimation of scaling factors for hard-to-measure radionuclides is given.

In the process of the Chornobyl NPP decommissioning, a large amount of equipment is dismantled, the metal of which has only the surface radioactive contamination. Under condition of successful decontamination of this metal, it is possible to release it from the regulatory control by clearance. The study of complete volume of the metal being dismantled for hard-to-measure radionuclides (HMR) content is a complex and expensive task. Reducing the cost for HMR specific activity measurement is possible by measuring key radionuclides followed by calculating HMR using the empirical scaling factors (SF).

The main objectives of this work were to determine the activity of key radionuclides (KR) and HMR in the surface contamination layer of the decontaminated metal and to calculate the corresponding SF. To achieve the set objectives, it was necessary to solve the problem of measuring the specific activity of KR and HMR at the levels below the established exemption criteria.

These studies were carried out to the order of the SSE "Chornobyl NPP", the main results are presented in the research report.

The measurements were carried out in four stages. The first stage was the preparation of the counting sample and measurement of the gamma-emitting radionuclides activity, including key radionuclides ${ }^{60} \mathrm{Co}$ and ${ }^{137} \mathrm{Cs}$. The second stage was the dissolution of the counting sample after gamma spectrometry in the mixture of nitric and hydrochloric acids and the selection of an aliquot for the radiochemical analysis of ${ }^{55} \mathrm{Fe},{ }^{59} \mathrm{Ni},{ }^{63} \mathrm{Ni}$. The third stage was the selection of an aliquot for the radiochemical analysis of ${ }^{239,}{ }^{240} \mathrm{Pu},{ }^{238} \mathrm{Pu},{ }^{241} \mathrm{Pu},{ }^{241} \mathrm{Am},{ }^{234} \mathrm{U},{ }^{235,}{ }^{236} \mathrm{U},{ }^{238} \mathrm{U}$. The fourth stage is the selection of a sample weight of the analytical material and determination of ${ }^{10} \mathrm{Be}$ activity.

Based on the criteria of referring radionuclides as key, of those listed in the Tables 2, 3, ${ }^{60} \mathrm{Co}$ and ${ }^{137} \mathrm{Cs}$ can be considered as such radionuclides. The calculated correlation coefficients between these radionuclides and some of HMR are presented as the following values: ${ }^{60} \mathrm{Co}-{ }^{63} \mathrm{Ni}-0.60 ;{ }^{137} \mathrm{Cs}-{ }^{90} \mathrm{Sr}-0.44$; ${ }^{137} \mathrm{Cs}-{ }^{239,}{ }^{240} \mathrm{Pu}-0.61 ;{ }^{137} \mathrm{Cs}-{ }^{241} \mathrm{Pu}-0.64 ;{ }^{137} \mathrm{Cs}-{ }^{241} \mathrm{Am}-0.66$.

The approaches to sampling used in this work and measurement methods made it possible to fairly reliably determine the activity of HMR in the metal samples of the ChNPP equipment being dismantled and to calculate SF for them and their total uncertainties that can be used in practice.

The large values of the total uncertainty of the scaling factors are due to the differences in the radionuclide ratios of radioactive contamination of the studied equipment fragments, the cause of which may be the differential use of decontamination (decontamination only of those fragments, which contamination levels exceeded the established levels, was carried out).

The obtained results allow us to conclude that, in order to determine SF for the purpose of exemption, it is necessary to apply the careful approach to the formation of the RM flux, for which the same method of decontamination is used.

Keywords: Chornobyl nuclear power plant, scaling factor, hard-to-measure radionuclide, specific activity, radioactive waste, release. 


\section{References}

1. NP 306.4.159-2010. Order of radioactive materials release in the framework of the practical activity. Kyiv, 2010. (in Ukr.)

2. ISO 21238:2007. Nuclear Energy - Nuclear Fuel Technology - Scaling Factor Method to Determine the Radioactivity of Low- and Intermediate-level Radioactive Waste Packages Generated at Nuclear Power Plants. International Organization for Standardization, 2007, 23 p.

3. International Atomic Energy Agency (2009) Determination and Use of Scaling Factors for Waste Characterization in Nuclear Power Plants. IAEA Nuclear Energy Series, No. NW-T-1.18, Vienna.

4. Research effort report "Vypolneniye izmereniy obraztsov metalla oborudovaniya, demontiruyemogo $v$ mashinnom zale pervoy ocheredi GSP CHAES s posleduyushchim raschetom koeffitsiyentov proportsionalnosti dlya trudnoizmeryayemykh radionuklidov" [Measurement of metal samples of equipment dismantled in the turbine hall of the SSE ChNPP 1st Stage with the further calculation of the proportionality coefficients for hard-to-measure radionuclides], State Scientific and Research Institution "Chornobyl Center for Nuclear Safety, Radioactive Waste and Radioecology", Slavutych. 2016. (in Russ.)

4. Terms of Reference for dismantling, processing, release of the equipment and constructions of the turbine hall of the SSE ChNPP Unit 1. (in Ukr.)

5. Gerasimov V. V., Kasperovich A. I., Martynova O. I. (1976) Vodnyy rezhim atomnykh stantsiy [Water regime of nuclear power plants]. Moscow: Atomizdat, 400 p. (in Russ.)

6. Bariahtar V. G. (Ed.) (1995) Chernobylskaya katastrofa [Chernobyl accident]. Kyiv: Naukova Dumka, 559 p. (in Russ.)

7. Gerasko V. N., Klyuchnikov A. A., Korneev A. A., Kupny V. I., et al. (1997) Obyekt "Ukrytiye". Istoriya, sostoyaniye $i$ perspektivy [Shelter Object. History, status and prospects]. Kyiv, Intergraph, 224 p. (in Russ.)

8. DollezhalN.A.(1983)Analizprichin iposledstviyavariynogo razryva kanala 62-44 reaktora bloka №1 Chernobylskoy AES [Analysis of the reasons and consequences of the emergency rupture of channel 62-44 of the Chernobyl NPP Unit 1 reactor. Report 4.50], Moscow. (in Russ.)
9. FA RBMK-1000. Technical description, 862.00.000 TO. (in Russ.)

10. Technological radiation criteria, 39E-RPD. SSE Chernobyl NPP, 2016, 22 p. (in Russ.)

11. Passport No. 01-0041-05 for the radionuclide source of metrological designation of OISN type with radionuclides europium-152, cesium-137, titanium-44. Odesa: State Enterprise "Odessa Research and Production Center for Ecological Safety”, 2005. (in Russ.)

12. Bock R. (1984) Metody razlozheniya v analiticheskoy khimii [Methods of decomposition in analytical chemistry]. Chemistry, Moscow, 432 p. (in Russ.)

13. Bondarkov M. D., Maksimenko A. M., Oskolkov B. Ya., et al. (2013) Research effort report "Determination of radioisotope composition and activity of special items in the central halls of Units 1,2, 3, which are not subject to LLCL waste processing. Development of methods for measuring special products. Preparation of proposals on their management". Slavutych: SSRI "Chornobyl Center for Nuclear Safety, Radioactive Waste and Radioecology”. (in Russ.)

14. Vajda N., Molnar Zs., Kabai E., Osvath Sz. (2003), Simultaneous determination of long-lived radionunuclides in environmental samples. Environmental Radiochemical Analysis II, June, 185-196 pp.

15. Operating Manual. FHT 770 T Multi-Low-LevelCounter for measurement of low level alpha and beta activity in samples up to $60 \mathrm{~mm}$ diameter. Eberline Instruments.

16. IAEA Analytical Quality in Nuclear Applications Series No. 37 (2014) A Procedure for the Sequential Determination of Radionuclides in Environmental Samples. International Atomic Energy Agency, Vienna.

17. IAEA Analytical Quality in Nuclear Applications No. IAEA/ AQ/11 (2009) A Procedure for the Rapid Determination of Pu Isotopes and Am-241 in Soil and Sediment Samples by Alpha Spectrometry. International Atomic Energy Agency, Vienna.

18. Ampelegova N. I., Simanovsky Yu. M., Trapeznikov A. A. (1982) Dezaktivatsiya $v$ yadernoy energetike [Decontamination in nuclear power]. Moscow: Energoizdat, 256 p. (in Russ.)
Надійшла 28.03.2019

Received 28.03.2019 


\author{
В. К. Шинкаренко, В. О. Кашпур, Г. Г. Скоряк, О. А. Свирид \\ Інститут проблем безпеки АЕС НАН України, вул. Кірова, 36а, м. Чорнобиль, 07270, Украӥна
}

\title{
Новий безпечний конфайнмент і радіоактивні аерозолі в ближній зоні Чорнобильської атомної електростанції
}

\author{
Ключові слова: \\ об'єкт «Укриття», \\ Новий безпечний конфайнмент, \\ об'ємна активність повітря, \\ гарячі частинки, \\ авторадіографія.
}

\begin{abstract}
Наведено дані про стан забруднення радіоактивними аерозолями приземного шару атмосфери ближньої зони Чорнобильської атомної електростанції після спорудження арки нового безпечного конфайнмента (НБК). Незважаючи на досить високу питому активність повітря під накриттям НБК внаслідок проведення робіт під ним, на прилеглій території спостерігається зменшення рівня забруднення приземного шару повітря не лише порівняно з рівнем під час будівництва арки, а й $з$ рівнем, що передував початку будівництва. На повітряних фільтрах, що були експоновані під аркою НБК, спостерігається зменшення частки крупних гарячих частинок, що пояснюється особливостями розташування пробовідбірника.
\end{abstract}

\section{Вступ}

Відомо, що створення об'єкта «Укриття» повністю не ліквідувало проблему викидів радіоактивних матеріалів у навколишнє середовище [1-3]. Будівництво нового безпечного конфайнмента (НБК) є одним з основних етапів перетворення 4-го енергоблока Чорнобильської атомної електростанції (ЧАЕС) на екологічно безпечну систему, покликану забезпечити безпеку персоналу, населення та навколишнього середовища [4]. У ході будівництва під час виконання комплексу робіт на промисловому майданчику та на прилеглій до об’єкта «Укриття» території відбувалося розпорошення раніше накопичених радіоактивних матеріалів з утворенням радіоактивних аерозолів. Наявність таких антропогенних джерел радіоактивного аерозолю змінної інтенсивності і тривалості в поєднанні 3 мінливістю метеорологічних умов істотно впливали на радіоаерозольну ситуацію поблизу об’єкта «Укриття» [5-7]. Основний елемент НБК - об'єкт «Арка» - було встановлено в кінці 2016 р., але сам об’єкт ще не зданий в експлуатацію, зокрема не проведена повна його герметизація. Необхідно відзначити, що крім завдання ізоляції 4-го енергоблока від навколишнього середовища, будівництво НБК повинно дати змогу безпечно проводити роботи з залишками блока, при цьому проектом допускаються досить високі рівні об'ємної активності радіоактивних ае-

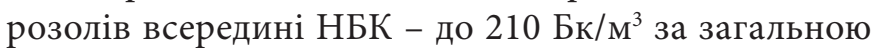
бета-активністю [8].

Метою роботи є дослідження динаміки аерозольної ситуації в ближній зоні ЧАЕС в умовах НБК протягом 2017 p.

\section{Матеріали та методика експерименту}

Відповідно до програми контролю радіаційного забруднення приземного шару атмосфери поблизу об'єкта «Укриття» протягом року в безперервному режимі працювали чотири фільтровентиляційні установки (ФВУ): ФВУ-1 «Ventmeca» розташована на схід від санпропускника СП-1430 приблизно за 500 м від південно-західного кута машинного залу; ФВУ-2 «Тайфун» - знаходиться на відстані 1,4 км, біля адміністративного корпусу об’єкта «Укриття»; ФВУ-3 «Град-1.8», яка була розміщена безпосередньо біля південної стіни машинного залу. Після монтажу об’єкта «Арка» ця ФВУ виявилась всередині НБК, де і продовжує працювати. ФВУ-4 - «Град-1.0» розташована 3 північної сторони 4-го блока (рис. 1).

(c) В. К. Шинкаренко, В. О. Кашпур, Г. Г. Скоряк, О. А. Свирид, 2019 
Таблиця 1. Основні технічні характеристики ФВУ

\begin{tabular}{|l|c|c|c|c|}
\hline \multicolumn{1}{|c|}{ Характеристики ФВУ } & $\begin{array}{c}\text { ФВУ-1 } \\
\text { «Ventmeca» }\end{array}$ & $\begin{array}{c}\text { ФВУ-2 } \\
\text { «Тйфун» }\end{array}$ & $\begin{array}{c}\text { ФВУ-3 } \\
\text { «рад-1.8» }\end{array}$ & $\begin{array}{c}\text { ФВУ-4 } \\
\text { «рад-1.0» }\end{array}$ \\
\hline Широта місцезнаходження & $51^{\circ} 23^{\prime} 13.0^{\prime \prime}$ & $51^{\circ} 23^{\prime} 39.9^{\prime \prime}$ & $51^{\circ} 23^{\prime} 17.9^{\prime \prime}$ & $51^{\circ} 23^{\prime} 26.8^{\prime \prime}$ \\
\hline Довгота місцезнаходження & $30^{\circ} 05^{\prime} 31.4^{\prime \prime}$ & $30^{\circ} 04^{\prime} 50.8^{\prime \prime}$ & $30^{\circ} 05^{\prime} 52.4^{\prime \prime}$ & $30^{\circ} 06^{\prime} 09.2^{\prime \prime}$ \\
\hline Висота відбирання проби, м & 1,0 & 2,5 & 1,8 & 1,0 \\
\hline Продуктивність, $\mathrm{M}^{3} /$ год & 300 & 4500 & 450 & 450 \\
\hline Площа фільтра, $\mathrm{M}^{2}$ & 0,36 & 0,78 & 0,56 & 0,56 \\
\hline
\end{tabular}

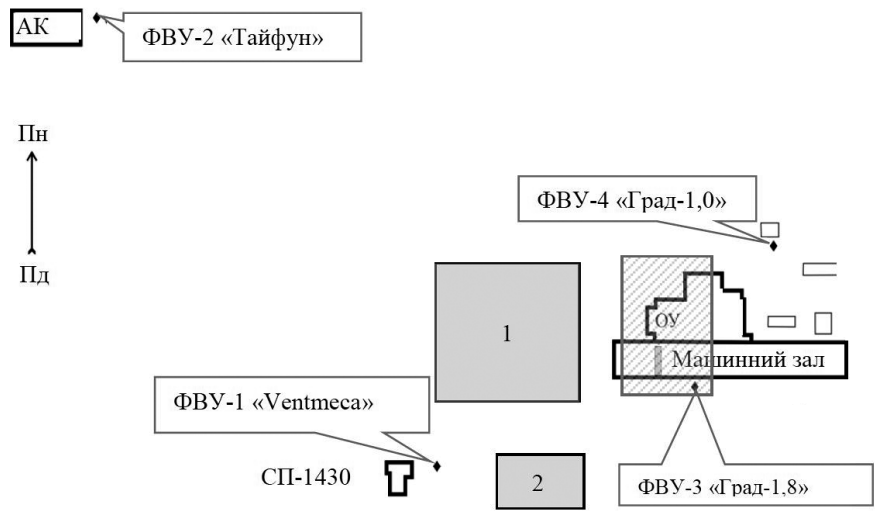

Рис. 1. Схема розташування ФВУ в ближній зоні об’єкта «Укиття»:

- орієнтовне положення об’єкта «Арка» (НБК-2);

- основний (1) та допоміжний (2) промислові майданчики

Основні характеристики ФВУ наведено в табл. 1. Матеріал повітряних фільтрів - тканина Петрянова ФПП-15-1,5. Періодичність зміни фільтрів 7 діб.

Вимірювання активності ${ }^{137} \mathrm{Cs}$ на повітряних фільтрах проводили за допомогою напівпровідникового гамма-спектрометра.

Одержання та обробку авторадіограм фрагментів фільтрів проводили відповідно до методик, описаних в $[9,10]$ з використанням медичної рентгенівської плівки фірми Carastream.

\section{Результати та їх обговорення}

Динаміка питомої активності повітря у приземному шарі атмосфери поблизу об'єкта «Укриття» представлена на рис. 2. (ФВУ-3 («Град-1.8») 301.03 по 15.05.2017 р. не працювала у зв'язку з проведенням робіт безпосередньо біля ФВУ та ії ремонтом.) Необхідно зазначити, що на ФВУ, розташованих поза межами НБК, спостерігається суттєве зниження об’ємної активності ${ }^{137} \mathrm{Cs}$ у порівнянні з роками до будівництва НБК і особливо в період будівництва самого НБК (рис. 3).
У той же час активність ${ }^{137} \mathrm{Cs}$ в повітрі під накриттям НБК внаслідок виконання робіт з демонтажу радіоактивно забруднених об'єктів залишалась досить високою. Матрицю кореляцій між об'ємними активностями ${ }^{137} \mathrm{Cs}$ в приземному шарі повітря поблизу ФВУ 1-4 наведено в табл. 2. Спостерігаються незначні, але статистично достовірні кореляції між об’ємними активностями для ФВУ, розташованих поза межами НБК (ФВУ-1, -2, -4). Водночас достовірні кореляції між об'ємними активностями всередині (ФВУ-3) і зовні НБК відсутні. Це свідчить про відсутність суттєвого впливу виносу радіоактивного аерозолю з-під об' єкта «Арка» на об'ємну активність аерозолю в інших пунктах спостережень.

Зауважимо, що в період будівництва спостерігались достовірні кореляції між об'ємними активностями поблизу ФВУ-3 та розташованими неподалік ФВУ-1 і ФВУ-4. Це свідчило про перекриття аерозольними хмаринами, що виникли під час проведення демонтажу фрагментів машинного залу, місць розташування цих ФВУ [7].

Авторадіограми, наведені на рис. 4, ілюструють відмінності картини аерозольного забруднення всередині і зовні НБК. Авторадіограма зліва містить велику кількість плям, обумовлених гарячими частинками (ГЧ). Для порівняння взято авторадіограму повітряного фільтра ФВУ-1 «Ventmeca» від 18-25.07.2017 р., оскільки авторадіограма від 20-26.09.2017 р. виявилася неінформативною, тобто практично чистою внаслідок малої об'ємної активності ${ }^{137} \mathrm{Cs}$ поблизу ФВУ-1 у цей час.

Результати визначень числа ГЧ, сумарної бета-активності досліджених фрагментів, мінімальні і максимальні значення активності виявлених ГЧ представлено в табл. 3. Зауважимо, що мінімальні значення активності ГЧ, які виявлено на фільтрі, відповідають обмеженням авторадіографічного методу визначення за таких умов, а аж ніяк не відсутністю 

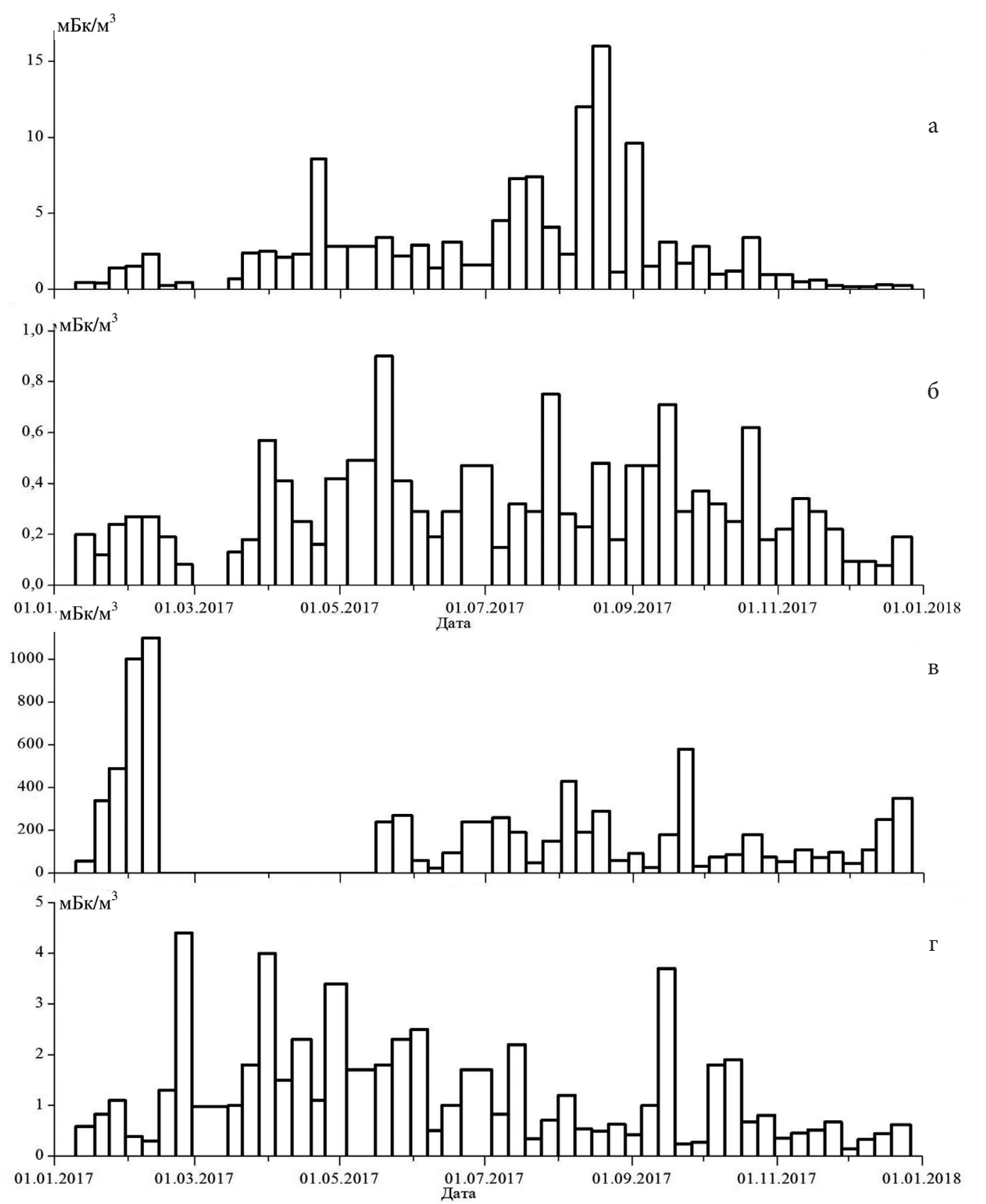

Рис. 2. Динаміка об’ємної активності ${ }^{137} \mathrm{Cs}$ у приземному шарі повітря поблизу об’єкта «Укриття»: a - ФВУ-1 «Ventmeca»; 6 - ФВУ-2 «Тайфун»; в - ФВУ-3 «Град-1.8»; г - ФВУ-4 «Град-1.0»

Таблиця 2. Коефіцієнти парних кореляцій об'ємних активностей аерозолів ${ }^{137}$ Cs у місцях розташування ФВУ

\begin{tabular}{|l|c|c|c|c|}
\hline & ФВУ-1 & ФВУ-2 & ФВУ-3 & ФВУ-4 \\
\hline ФВУ-1 & 1 & $\mathbf{0 , 3 6}$ & 0,01 & $-0,07$ \\
\hline ФВУ-2 & $\mathbf{0 , 3 6}$ & 1 & 0,00 & $\mathbf{0 , 3 7}$ \\
\hline ФВУ-3 & 0,01 & 0,00 & 1 & $-0,16$ \\
\hline ФВУ-4 & $-0,07$ & $\mathbf{0 , 3 7}$ & $-0,16$ & 1 \\
\hline
\end{tabular}

Примітка. Жирним шрифтом виділено коефіцієнти з рівнем достовірності $\mathrm{p}>$ 0,95. 


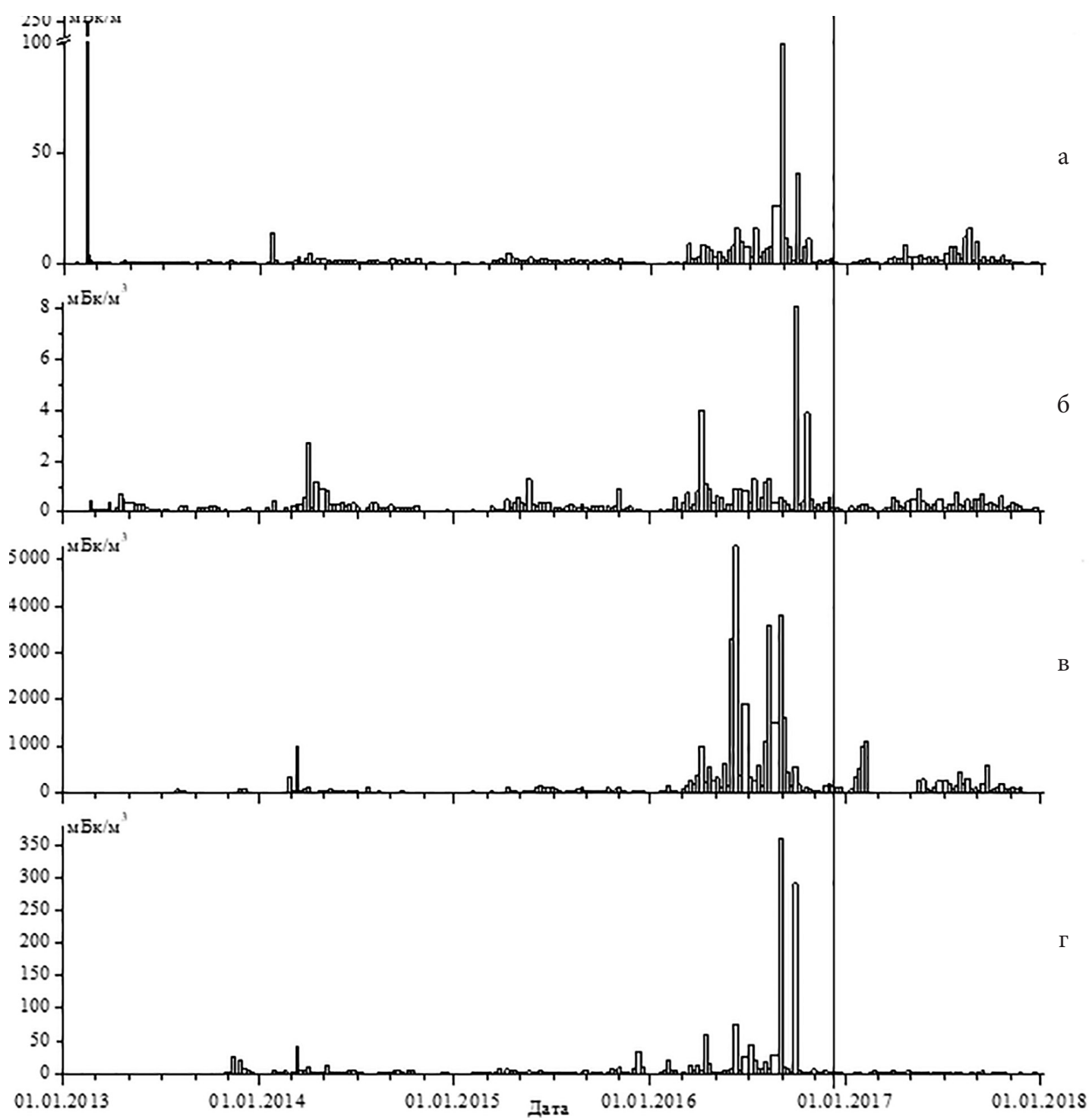

Рис. 3. Динаміка об’ємної активності ${ }^{137} \mathrm{Cs}$ у приземному шарі повітря поблизу об'єкта «Укриття»: а - ФВУ-1 «Ventmeca»; 6 - ФВУ-2 «Тайфун»; в - ФВУ-3 «Град-1.8»; г - ФВУ-4 «Град-1.0».

Вертикальною лінією відмічено час насування об’єкта «Арка»

Таблиця 3. Результати досліджень ГЧ на фрагментах фільтрів

\begin{tabular}{|c|c|c|c|c|c|c|c|}
\hline \multirow[t]{2}{*}{ Установка } & \multirow{2}{*}{$\begin{array}{c}\text { Дата } \\
\text { експозиції }\end{array}$} & \multirow{2}{*}{$\begin{array}{c}\text { Прокачаний } \\
\text { об’єм } \\
\text { повітря, м }{ }^{3}\end{array}$} & \multirow{2}{*}{$\begin{array}{c}\text { Активність }{ }^{137} \mathrm{Cs} \\
\text { на фільтрі, Бк }\end{array}$} & \multirow{2}{*}{$\begin{array}{c}\text { Знайдена } \\
\text { бета-активність на } \\
\text { фрагменті, Бк }\end{array}$} & \multicolumn{2}{|c|}{$\begin{array}{c}\text { Активність } \\
\text { частинки, Бк }\end{array}$} & \multirow{2}{*}{$\begin{array}{c}\text { Число ГЧ на } \\
\text { фрагменті }\end{array}$} \\
\hline & & & & & $\max$ & $\min$ & \\
\hline \multirow{5}{*}{ ФВУ-3 } & $24-31.01 .2017$ & 40723 & $2,00 \cdot 10^{4}$ & $3,57 \cdot 10^{3}$ & 21,4 & 0,304 & 3725 \\
\hline & $31.01-7.02 .2017$ & 40382 & $4,04 \cdot 10^{4}$ & $4,63 \cdot 10^{3}$ & 36,5 & 0,201 & 6450 \\
\hline & $07-14.02 .2017$ & 6000 & $6,60 \cdot 10^{3}$ & 949 & 41 & 0,034 & 4770 \\
\hline & $02-08.08 .2017$ & 30836 & $1,33 \cdot 10^{4}$ & 979 & 6,81 & 0,24 & 2284 \\
\hline & $20-26.09 .2017$ & 9000 & $5,31 \cdot 10^{3}$ & 723 & 4,44 & 0,034 & 3770 \\
\hline ФВУ-4 & $21-28.02 .2017$ & 40966 & $1,80 \cdot 10^{2}$ & 75 & 1,85 & 0,10 & 470 \\
\hline ФВУ-1 & $18-25.07 .2018$ & 60390 & $4,47 \cdot 10^{2}$ & 173 & 18,5 & 0,10 & 789 \\
\hline
\end{tabular}




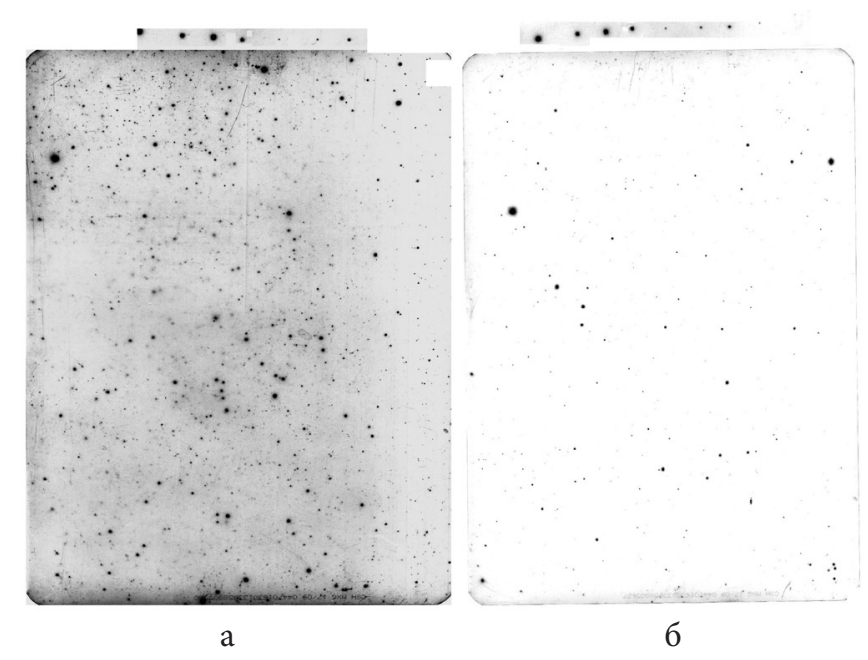

Рис. 4. Авторадіограми фрагментів повітряних фільтрів: а - ФВУ-3 «Град-1,8» від 20-26.09.2017 р.; б - ФВУ-1 «Ventmeса» від 18-25.07.2017 р. Вгорі - авторадіограми лінійки частинок 3 відомою активністю

ГЧ з меншими активностями. Бачимо, що мінімальні виявлені активності для фільтрів, експонованих всередині об'єкта «Арка», відповідають випадкам з мінімальними прокачаними об'ємами повітря. Це вказує на перевантаження фільтра ГЧ.

Одержані розподіли за логарифмом активності числа частинок та сумарної активності ГЧ на інтервалі наведено на рис. 5. Для зручності замість логарифмів активності наведені значення активностей, що відповідають цим інтервалам, в верхній частині наведено значення мінімально можливих діаметрів ${ }^{1}$ ГЧ. Зліва гістограми обмежені мінімальними активностями, що їх може виявити метод авторадіографії за таких умов. Для фрагмента (а) межа визначення зміщена в сторону більш активних часток. На фільтрі, що був експонований на тій же установці протягом меншого часу (б), спостерігаються ГЧ з суттєво меншими активностями.

\section{Висновки}

1. Після встановлення арки НБК у проектне положення в ближній зоні об’єкта «Укриття» спостерігається зменшення рівня забруднення приземного шару повітря, незважаючи на те, що внаслідок
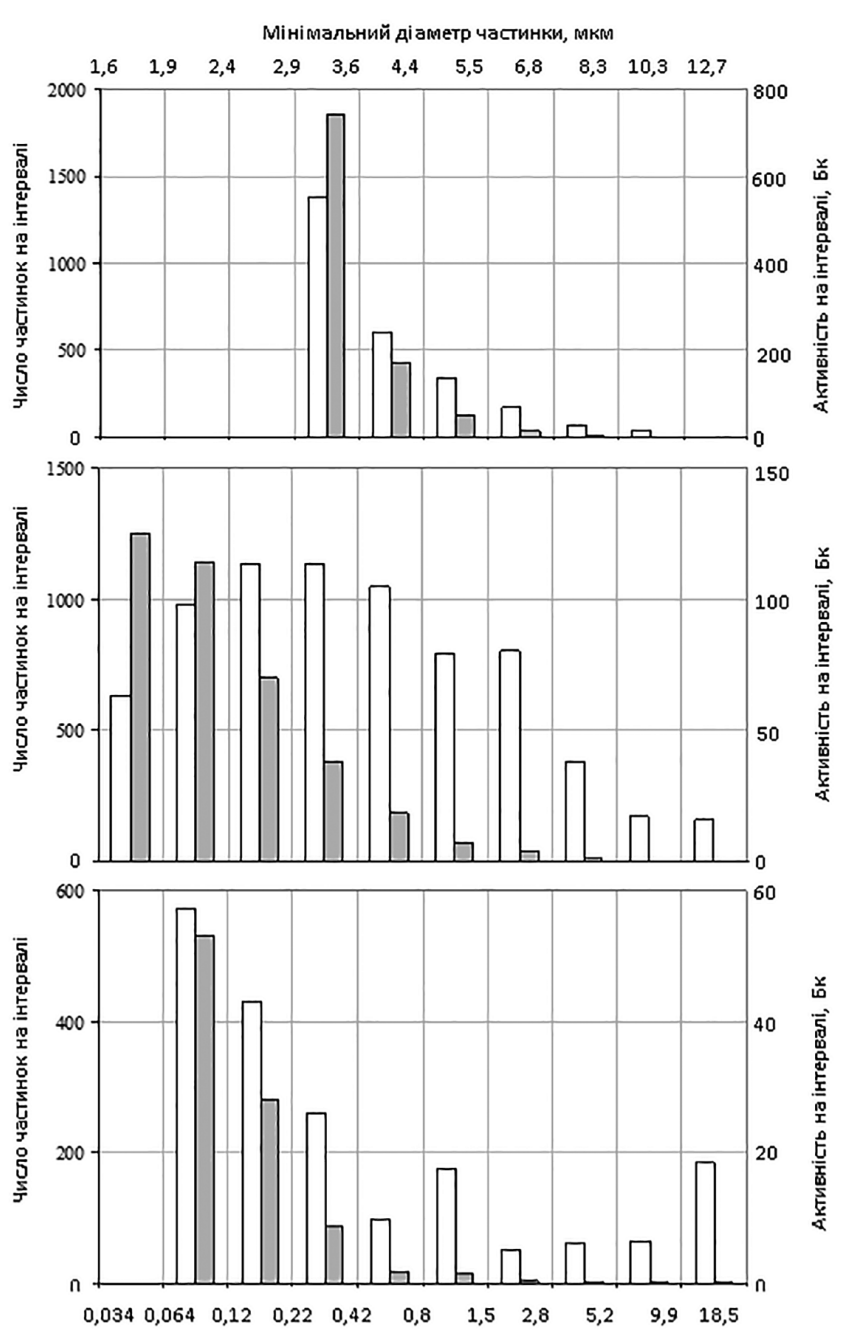

Рис. 5. Розподіл числа частинок та їхньої сумарної активності за інтервалами логарифма активності:

$\square$ - активність, $\square$ - число частинок; a - ФВУ-3, 02-08.08.2017 p., $V=30836 \mathrm{~m}^{3} ; 6-$ ФВУ-3,

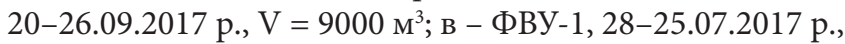
$\mathrm{V}=60390 \mathrm{M}^{3}$

проведення монтажних робіт питома активність повітря під накриттям НБК залишається досить високою.

2. Відсутність кореляцій між об’ємними активностями ${ }^{137} \mathrm{Cs}$ у повітрі всередині (ФВУ-3) і зовні НБК свідчить про відсутність суттєвого впливу виносу радіоактивного аерозолю 3-під об'єкта «Арка» на об'ємну активність аерозолю в інших пунктах спостережень.

1. Авторадіографічні дослідження дозволяють оцінити сумарну бета-активність окремих ГЧ. Знаючи середню питому активність опроміненого палива, можна знайти мінімальний аеродинамічний діаметр паливної частки 3 даною бета-активністю. Гаряча частинка з такою ж активністю, але іншого ізотопного складу (з меншою питомою активністю) матиме відповідно більший аеродинамічний діаметр. Аналогічне збільшення аеродинамічного діаметра відбудеться в разі об’єднання паливної частки з неактивною пиловою часткою з утворенням великої частинки-наїзника. 
3. Розташований в ізольованій частині простору під аркою НБК (між південною стіною машинного залу і стіною самої арки) пробовідбірник Град-1,8 дає дещо спотворену картину розподілу ГЧ за активністю, що виражається у відсутності великих високоактивних частинок, що, імовірно, випадають поблизу місць проведення робіт під аркою раніше, ніж встигають перелетіти стіну машинного залу.

4. Для одержання об’єктивної картини розподілу ГЧ в просторі під аркою НБК необхідно встановити хоча б один додатковий пробовідбірник в районі центральної частини під аркою. 3 огляду на досить високі активності радіоактивних аерозолів бажано зменшити час експозиції повітряних фільтрів.

5. Для з'ясування питання про дійсні аеродинамічні діаметри ГЧ необхідні вимірювання за допомогою імпактора.

\section{Список використаної літератури}

1. Гаргер Е. К. Физико-химические характеристики аэрозоля 30-километровой зоны ЧАЭС в 19862013 гг. / Е. К. Гаргер, В. О. Кашпур, Г. Г. Скоряк, В. К. Шинкаренко // Проблеми безпеки атомних електростанцій і Чорнобиля. - 2014. - Вип. 23. C. 54-65.

2. Огородников Б. И. Радиоактивные аэрозоли объекта «Укрытие»: 1986-2006 гг. : монография / Б. И. Огородников, Э. М. Пазухин, А. А. Ключников. - Чернобыль : ИПБ АЭС НАН Украины, 2008. 456 с.

3. Огородников Б. И. Радиоактивные аэрозоли объекта «Укрытие» (обзор). Ч. 2.2: Концентрации радиоактивных аэрозолей на промплощадке объекта «Укрытие» / Б. И. Огородников, Н. И. Павлюченко, Э. М. Пазухин Чернобыль, 2004. - 44 с. - (Препринт / НАН Украины, МНТЦ «Укрытие»; 04-1).

4. Закон України «Про загальні засади подальшої експлуатації і зняття з експлуатації Чорнобильської АЕС та перетворення зруйнованого четвертого енергоблока цієї АЕС на екологічно безпечну систему» від 11.12.1998 р. № 309-XIV // Відомості Верховної Ради України. - 1999. - № 4. - С. 33.

5. Шинкаренко В. К. Результаты исследований аэрозольных фильтров, экспонированных до, во время и после разрушения крыши машинного зала 4-го энергоблока Чернобыльской АЭС / В. К. Шинкаренко, В. О. Кашпур, Г. Г. Скоряк // Проблеми безпеки атомних електростанцій і Чорнобиля. - 2014. - Вип. 23. - С. 45-53.

6. Шинкаренко В. К. Оценка аэрозольной радиационной обстановки на промплощадке ЧАЭС во время проведения работ по строительству НБК / В. К. Шинкаренко, В. О. Кашпур, Г. Г. Скоряк,
А. К. Калиновский // Проблеми безпеки атомних електростанцій і Чорнобиля. - 2016. - Вип. 27. - С. 58-66.

7. Garger E. K. Assessment of aerosol radiation environment in short-range region of ChNPP during building of the new safe confinement // E. K. Garger, V. K. Shynkarenko, V. A. Kashpur, G. G. Skorjak, A. K. Kalinovsky. - 2017. No. 29. - pp. 78-84.

8. Документ з безпеки в рамках концепції проекту ПК-1 НБК / SIP-N-LI-22-A500_-CDS-001-01. Revision 1-Appendix. - 2008. - 63 c.

9. Шинкаренко В. К. К определению активности «горячих» частиц радиографическим методом / В. К. Шинкаренко // Проблеми безпеки атомних електростанцій і Чорнобиля. - 2008. - Вип. 9. C. $130-139$.

10. Шинкаренко В. К. К вопросу о погрешностях определения $\beta$-активности горячих частиц методом авторадиографии / В. К. Шинкаренко // Проблеми безпеки атомних електростанцій і Чорнобиля. - 2018. Вип. 30. - С. 109-118. - doi.org/10.31717/18133584.18.30.13.

\section{В. К. Шинкаренко, В. А. Кашпур, Г. Г. Скоряк, А. А. Свирид}

Институт проблем безопасности АЭС НАН Украины, ул. Кирова, 36а, м. Чернобыль, 07270, Украина

\section{Новый безопасный конфайнмент и радиоактивные аэрозоли в ближней зоне Чернобыльской атомной электростанции}

Приведены данные о состоянии загрязнения радиоактивными аэрозолями приземного слоя атмосферы ближней зоны Чернобыльской атомной электростанции после сооружения арки нового безопасного конфайнмента (НБК). Несмотря на достаточно высокую удельную активность воздуха под навесом НБК в результате проведения работ под ним, на прилегающей территории наблюдается уменьшение уровня загрязнения приземного слоя воздуха не только по сравнению с уровнем при строительстве арки, но и с уровнем, предшествовавшим началу строительства.

На воздушных фильтрах, экспонированных под аркой НБК, наблюдается уменьшение доли крупных горячих частиц, что объясняется особенностями расположения установленного здесь пробоотборника.

Ключевые слова: объект «Укрытие», новый безопасный конфайнмент, объемная активность воздуха, горячие частицы, авторадиография. 


\section{K. Shynkarenko, V. A. Kashpur, G. G. Skorjak, A. A. Svirid}

Institute for Safety Problems of Nuclear Power Plants, NAS of Ukraine, Lysogirska str., 12, Kyiv, 03028, Ukraine

\section{New Safe Confinement and Radioactive Aerosols in Short-Range Region of Chornobyl Nuclear Power Plant}

The construction of a new safe confinement (NSC) is one of the main stages in transforming the 4th power unit of the Chernobyl Nuclear Power Plant into an environmentally safe system designed to ensure safety of personnel, public and environment. Additionally to the task of isolating the 4th power unit from the environment, the construction of the NSC should enable safe work with residues of the 4th unit, while the project allows quite high levels of volumetric activity of radioactive aerosols inside the NSC - up to 210 $\mathrm{Bq} / \mathrm{m} 3$ in total beta activity. The purpose of this work is to study the dynamics of the aerosol situation in the near zone of the Chernobyl NPP under the influence of the NSC during 2017.

The sampling of the aerosol was carried out by filtering air through filters from Petryanov tissue, the exposure time was 7 days.

The data on the contamination by radioactive aerosols of the atmosphere surface layer in the near zone of the Chernobyl NPP after constructing the Arch of the new safe confinement are represented. Despite the relatively high air activity there the roof of the NSC, caused by work made under, the decrease of the surface air layer pollution on the adjacent territory comparable not only to the pollution level during the Arch construction, but also comparable to the level before the start of constructing, is observed. There are statistically significant correlations between the ${ }^{137} \mathrm{Cs}$ volume activities in the air near samplers located outside the NSC observed, while there are no significant correlations between the volume activities inside and outside the NSC. This indicates the absence of a significant effect of the radioactive aerosol release from the "Arch" object on the volume activity of the aerosol at other observation points.

On air filters exposed under the NSC Arch, a decrease in the proportion of large hot particles is observed, that could be explained by the peculiarities of local sampler positioning.

Keywords: Shelter object, new safe confinement, volumetric air activity, hot particles, autoradiography.

\section{References}

1. Garger E. K., Kashpur V. A., Skorjak G. G., Shynkarenko V. K. (2014). [Physical and chemical characteristics of the aerosol of the $30 \mathrm{~km}$ zone of ChNPP in 1986-2013]. Problemy bezpeky atomnyh elektrostantsiy $i$ Chornobylya [Problems of nuclear power plants safety and of Chornobyl], vol. 23, pp. 54-64. (in Ukr.)

2. Ogorodnikov B. I., Pazukhin E. M., Kliuchnykov A. A. (2008). Radioaktivnye aerozoli obekta "Ukrytie": 1986-2006 gg. [Radioactive aerosols of the Shelter object: 1986-2006]. Chornobyl: ISP NPP NAS of Ukraine, 456 p. (in Russ.)

3. Ogorodnikov B. I., Pavlyuchenko N. I., Pazukhin E. M. (2004). Radioaktivnye aerozoli obekta "Ukrytie" (obzor). Ch. 2.2: Kontsentratsii radioaktivnykh aerozoley na promploshchadke obekta "Ukrytie" [Radioactive aerosols of the Shelter object (a review). Part 2.2. Concentrations of radioactive aerosols in industrial site of the Shelter object] [Preprint]. Chornobyl: ISTC "Shelter", 44 p. (in Russ.)

4. The Law of Ukraine "On General Principles of Further Operation and Decommissioning of Chornobyl NPP and Transformation of Ruined Fourth Power Unit of This NPP into Ecologically Safe System" of December 11, 1998, No. 309-XIV. Vidomosti Verkhovnoi Rady Ukrainy, no. 4, p. 33. (in Ukr.)

5. Shynkarenko V. K, Kashpur V. A., Skorjak G. G. (2014). [Results of studies of the aerosol filters exposed before, during and after the destruction of the roof of the machine hall of Chernobyl NPP 4th block]. Problemy bezpeky atomnyh elektrostantsiy $i$ Chornobylya [Problems of nuclear power plants safety and of Chornobyl], vol. 23, pp. 45-53. (in Russ.)

6. Shynkarenko V. K., Kashpur V. A., Skorjak G. G., Kalinovsky A. K. (2016). [Assessment of aerosol radiation situation on ChNPP industrial platform during work on building a New safe confinement]. Problemy bezpeky atomnyh elektrostantsiy $i$ Chornobylya [Problems of nuclear power plants safety and of Chornobyl], vol. 27, pp. 5866. (in Russ.)

7. Garger E. K., Shynkarenko V. K., Kashpur V. A., Skorjak G. G., Kalinovsky A. K. (2017). [Assessment of aerosol radiation environment in short-range region of ChNPP during building of the New safe confinement]. Problemy bezpeky atomnyh elektrostantsiy $i$ Chornobylya [Problems of nuclear power plants safety and of Chornobyl], vol. 29, pp. 78-84.

8. NSC CS-1 Concept Design Safety Document SIP-N-LI-22A500_-CDS-001-01. Revision 1-Appendix, 2008, 63 p.

9. Shynkarenko V. K. (2008). [To definition of activity of hot particles by a radiographic method]. Problemy bezpeky atomnyh elektrostantsiy $i$ Chornobylya [Problems of nuclear power plants safety and of Chornobyl], vol. 9, pp. 130-139. (in Russ.)

10. Shynkarenko V. K. (2018). [To problems of hot particles $\beta$-activity determination errors by the autoradiography method]. Problemy bezpeky atomnyh elektrostantsiy $i$ Chornobylya [Problems of nuclear power plants safety and of Chornobyl], vol. 30, pp. 109-118. doi. org/10.31717/1813-3584.18.30.13. (in Russ.)

Надійшла 12.12.2018

Received 12.12.2018 
А. С. Лагуненко, В. Е. Хан, А. А. Одинцов, В. П. Ковальчук, Т. А. Кравчук, А. К. Калиновский, В. А. Кашпур, А. А. Свирид, А. В. Ткач, С. В. Юрчук

\section{Радиоактивные аэрозоли около скопления лавообразных топливосодержащих материалов в помещении 012/7 объекта «Укрытие» в 2017-2018 гг.}

Ключевые слова:

объект «Укрытие», лавообразные топливосодержащие материалы, радиоактивные аэрозоли, объемная активность, соотношение радионуклидов.
Представлены радионуклидный состав и объемные активности аэрозолей и их выпадений в помещении 012/7 объекта «Укрытие» в 2017-2018 гг. Пробы отбирали в 0,5 м от южного края лавообразных топливосодержащих материалов (ЛТСМ). Установлено, что суммарная концентрация аэрозолей-носителей ${ }^{90} \mathrm{Sr}+{ }^{90} \mathrm{Y}$ и ${ }^{137} \mathrm{Cs}$ колебалась в диапазоне 0,1-6 Бк/м². При этом на долю ${ }^{137} \mathrm{Cs}$ приходилось $33 \%$. Гамма-спектрометрические измерения и радиохимические анализы показали, что усредненные отношения радионуклидов-продуктов аварии 4-го блока ЧАЭС в аэрозольных пробах и образцах ЛТСМ практически идентичны. Это свидетельствует о том, что происходит деструкция ЛТСМ и частичный переход материалов в аэрозольное состояние.

\section{Введение}

В первые дни после аварии на Чернобыльской атомной электростанции (ЧАЭС) в 1986 г. произошло формирование лавообразных топливосодержащих материалов (ЛТСМ), в которых находилось большое количество ядерного топлива и радиоактивных продуктов деления. При растекании лава оказалась во многих помещениях, в том числе в подаппаратном помещении (на высотной отметке $+9,00$ ), парораспределительном коридоре (на отметке $+6,00$ ), бассейне-барботере (на отметке+3,00 и 0,00) и других местах [1].

Хотя с момента аварии и образования ЛТСМ прошло более 30 лет, сведений об их состоянии, а тем более разрушении, крайне мало. В этом плане важные исследования радиоактивного аэрозоля были проведены в 2010-2011 гг. в помещении 012/7 на самой низкой высотной отметке (0 м) объекта «Укрытие», куда протекла лава [2]. Пробы аэрозоля отбирали на трехслойные фильтры Петрянова в 15-20 см от южного края ЛТСМ. Установлено, что в воздухе помещения объемная активность суммы долгоживущих бета-излучающих нуклидов $(\Sigma \beta)$, представленных ${ }^{90} \mathrm{Sr}+{ }^{90} \mathrm{Y},{ }^{137} \mathrm{Cs}$, колебалась в диапазоне 5-100 Бк/ $/ \mathrm{M}^{3}$. При этом на долю ${ }^{137} \mathrm{Cs}$ приходилось не более 10-20\%. Отношение концентраций ${ }^{137} \mathrm{Cs} /{ }^{241} \mathrm{Am}$ было близко к 15. Носителями радионуклидов были аэрозоли крупнее 1 мкм. Состав и отношения радионуклидовпродуктов аварии 4-го блока ЧАЭС в аэрозольных пробах и образцах ЛТСМ оказались практически идентичными. Авторы публикации [2] считают, что в помещении 012/7 происходила деструкция лавы и ее частичный переход в аэрозольное состояние.

27 ноября 2016 г. «Арка» нового безопасного конфайнмента (НБК) была установлена в проектное положение над объектом «Укрытие». Завершение создания НБК в 2018 г. обусловливает кардинальное изменение ряда факторов внешнего влияния на ЛТСМ: прекращение поступления осадков из окружающей среды в помещения объекта «Укрытие», смещение средней сезонной температуры в объекте в положительную сторону. В результате изменения температурно-влажностного режима происходит постепенное высыхание водных скоплений и () А. С. Лагуненко, В. Е. Хан, А. А. Одинцов, В. П. Ковальчук, Т. А. Кравчук, А. К. Калиновский, В. А. Кашпур, А. А. Свирид, А. В. Ткач, С. В. Юрчук, 2019 
понижение влажности воздухав помещениях сЛТСМ. Это, в свою очередь, может привести к значительному повышению концентрации радиоактивного аэрозоля в помещениях объекта «Укрытие» в результате вторичного пылеподъема с поверхностей ЛТСМ. Последнее предопределило необходимость систематических исследований воздушной среды, в частности радиоактивных аэрозолей, непосредственно в местах локализации ЛТСМ при фактических температурных, влажностных, воздухообменных, радиационных и других условиях, существующих в объекте «Укрытие». Этому посвящена данная работа, выполненная в 2017-2018 гг. в помещении 012/7.

\section{Описание помещения 012/7 и находящегося там скопления ЛТСМ}

Скопление ЛТСМ в помещении 012/7 расположено на высотной отметке 0,00 в системе бассейна-барботера 4-го блока ЧАЭС. В соответствии с [3] ширина скопления в основании (направление запад-восток) $\sim 2$ м, длина (направление север-юг) $~ 3$ м. Его наибольшая высота над полом $~ 0,8$ м. Скопление до уровня $0,2-0,4$ м над полом залито бетоном, поступавшим сюда в 1986 г. при возведении каскадной стены объекта «Укрытие». В этом скоплении, получившем название «куча ББ- 1 », содержится 1,0 \pm 0,5 т урана (рис. 1).

При экспериментах по пылеподавлению и локализации ЛТСМ в марте 2000 г. южная половина скопления была покрыта слоем кремнийорганического

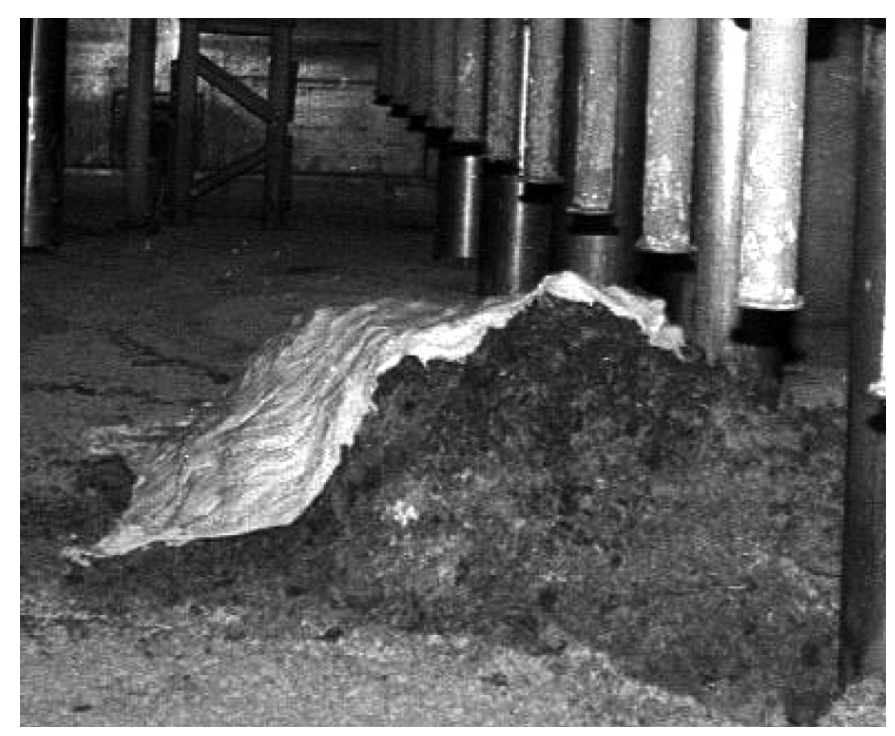

Рис. 1. Скопление ЛТСМ, частично укрытое «ЭКОР-25ММ» (белая пленка), в помещении 012/7 компаунда «ЭКОР-25ММ» толщиной 1-3 см [4]. Эта белая пленка видна на рис. 1. В связи с этим полностью открытая горизонтальная проекция ЛТСМ составляет около 2,5 м². Доступ к скоплению ЛТСМ возможен из коридора 006/2 через помещения $009 / 4$ и 012/8.

\section{Методы и средства отбора проб и измерений}

Аэрозоли отбирались с помощью воздухоотборника типа RadeCo H810 в течение суток со скоростью, обеспечивающей за время экспозиции около $100 \mathrm{M}^{3}$ прокачиваемого воздуха.

Использовались пакеты, состоящие из фильтров АФА РСП-20 и АФА РМП-20 площадью $20 \mathrm{~cm}^{2}$. Пакеты устанавливались в специальном фильтродержателе. После окончания сеанса проботбора пакеты демонтировались, фильтры осматривались на наличие внешних повреждений и в полиэтиленовых пакетах отправлялись на анализ. Пробы аэрозоля отбирали в непосредственной близости (на расстоянии примерно 0,5 м) от южного края скопления ЛТСМ. Вся аппаратура размещалась на специальной тележке (рис. 2 и 3), которую затем вкатывали в помещение 012/7 к южному концу скопления ЛТСМ, т. е. условия пробоотбора были такие же, как и в 20102011 гг. [2].

Для оценки плотности выпадения аэрозоля в помещении рядом с воздухоотборником устанавливали кювету, на дне которой размещали фильтровальную бумагу (см. рис. 2 и 3). Отобранные пробы

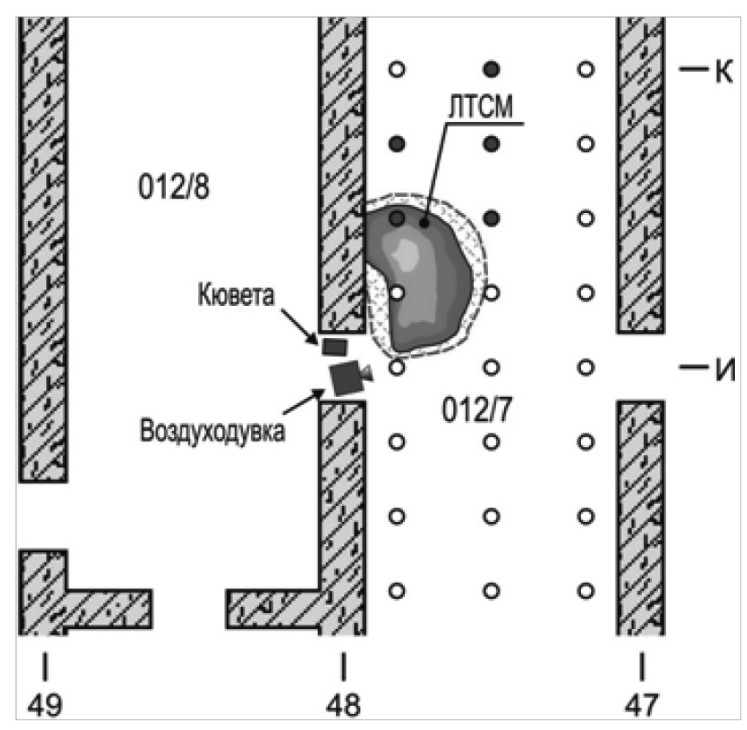

Рис. 2. Отбор проб аэрозоля из помещения 012/7 


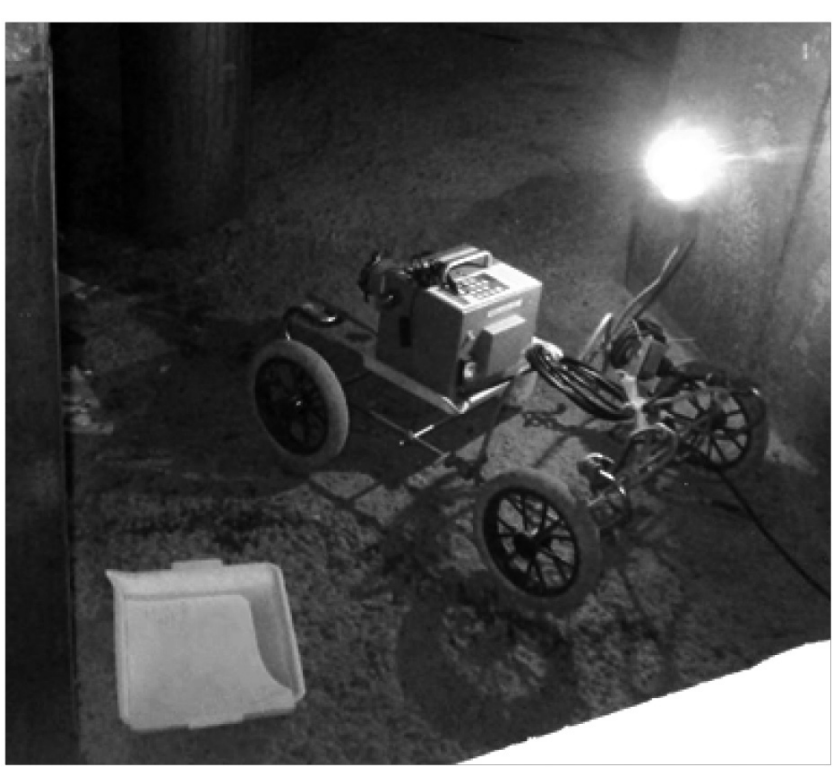

Рис. 3. Пробоотборный комплекс в непосредственной близости к скоплению ЛТСМ в помещении 012/7

в полиэтиленовых пакетах отправляли на анализ для проведения гамма-спектрометрических и радиохимических анализов.

Измерение бета-активности проб выполняли на приборе РКБ4-1ем через 4-5 сут., когда полностью распадались дочерние продукты радона и торона. В результате определяли содержание $\Sigma \beta$.

Последующие измерения радиоактивных веществ выполняли на гамма-спектрометрическом комплексе, состоящем из полупроводникового детектора GL2020R из сверхчистого германия с бериллиевым окном толщиной 500 мкм и 8192-канального амплитудного анализатора импульсов. Измерительный диапазон охватывает энергии от 10 до 1400 кэВ. Детектор имеет разрешение 0,57 и 1,2 кэВ для энергий гамма-квантов 122 кэВ (гамма-линия ${ }^{57} \mathrm{Co}$ ) и 661,6 кэВ (гамма-линия ${ }^{137} \mathrm{Cs}$ ) соответственно. По результатам измерений рассчитывали содержание в фильтрах ${ }^{137} \mathrm{Cs},{ }^{154} \mathrm{Eu} \mathrm{и}{ }^{241} \mathrm{Am}$.

Проба аэрозоля (от 15.02.11) и четыре пробы аэрозольного выпадения за 2017-2018 гг. были еще проанализированы радиохимическими методами. После озоления проб и растворения зольных остатков активность ${ }^{90} \mathrm{Sr}$ определяли бета-радиометрическими измерениями, a ${ }^{238} \mathrm{Pu},{ }^{239+240} \mathrm{Pu}$ и ${ }^{241} \mathrm{Am}$ - с помощью альфа-спектрометрии.

Впериодпроведенияотборовпробаэрозоля (май 2017 г. - июль 2018 г.) осуществлялась непрерывная фиксация значений температуры и относительной влажности в помещении 012/8 посредством регистратора Elitech RC-4HA/C, установленного в координатах И-2000/49-1500 (в 5 м от места пробоотбора). С февраля по май 2017 г. контроль этих параметров выполнялся с помощью гигротермометра TH-mini с выносным датчиком температуры-влажности.

\section{Результаты исследований}

Результаты радиометрических и гамма-спектрометрических измерений проб аэрозолей, отобранных из помещения 012/7, приведены в табл. 1. За период февраль 2017 г. - июль 2018 г. было отобрано 16 проб.

Таблица 1. Характеристики радиоактивных аэрозолей в помещении 012/7 объекта «Укрытие» в 2017-2018 гг.

\begin{tabular}{|c|c|c|c|c|c|}
\hline \multirow{2}{*}{$\begin{array}{c}\text { Дата } \\
\text { отбора }\end{array}$} & \multicolumn{4}{|c|}{ Концентрация, Бк/м³ } & \multirow{2}{*}{${ }^{137} \mathrm{Cs} / \Sigma \beta$} \\
\hline & ${ }^{137} \mathrm{Cs}$ & ${ }^{154} \mathrm{Eu}$ & ${ }^{241} \mathrm{Am}$ & $\sum \beta$ & \\
\hline \multicolumn{6}{|c|}{2017 г. } \\
\hline $14-15.02$ & 0,83 & $8,3 \cdot 10^{-3}$ & $6,4 \cdot 10^{-2}$ & 4,0 & 0,21 \\
\hline $11-12.04$ & $6,2 \cdot 10^{-2}$ & - & - & 0,11 & 0,56 \\
\hline $26-27.04$ & 0,24 & - & - & 0,82 & 0,29 \\
\hline $07-08.06$ & 0,55 & $4,4 \cdot 10^{-3}$ & $3,4 \cdot 10^{-2}$ & 2,4 & 0,23 \\
\hline $10-11.07$ & 0,38 & - & - & 0,83 & 0,46 \\
\hline $22-23.08$ & $7,2 \cdot 10^{-2}$ & - & - & 0,42 & 0,17 \\
\hline $11-12.09$ & $8,6 \cdot 10^{-2}$ & - & - & 0,17 & 0,51 \\
\hline $24-25.10$ & 0,14 & - & - & 0,22 & 0,64 \\
\hline $14-15.11$ & 0,74 & - & $3,2 \cdot 10^{-2}$ & 2,3 & 0,32 \\
\hline \multicolumn{6}{|c|}{2018 г. } \\
\hline $16-17.01$ & 1,5 & $9,7 \cdot 10^{-3}$ & $9,1 \cdot 10^{-2}$ & 5,8 & 0,26 \\
\hline $22-23.02$ & 0,67 & - & - & 2,6 & 0,26 \\
\hline $12-13.03$ & 0,62 & - & - & 2,8 & 0,22 \\
\hline $17-18.04$ & 0,20 & - & - & 1,7 & 0,12 \\
\hline $14-16.05^{\star}$ & 0,51 & - & $1,6 \cdot 10^{-2}$ & 4,1 & 0,12 \\
\hline 04-05.06 & $4,8 \cdot 10^{-2}$ & - & - & 0,12 & 0,40 \\
\hline $03-04.07$ & $4,7 \cdot 10^{-2}$ & - & - & $8,8 \cdot 10^{-2}$ & 0,57 \\
\hline
\end{tabular}

* $14-16.05 .18$ аэрозоли отбирались в течение 2 сут.

(200 м³ прокачанного воздуха).

В период с февраля 2017 г. по июль 2018 г. наиболее высокие концентрации ${ }^{137} \mathrm{Cs}$ в воздухе помещения 012/7 зарегистрированы 17 января 2018 г., а наиболее низкие - 4 июля 2018 г. За весь период наблюдения величина $\Sigma \beta$ варьировала в диапазоне

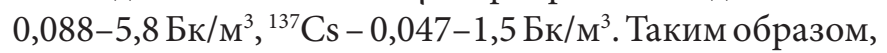
минимальные и максимальные значения активности 
${ }^{137} \mathrm{Cs}$ и $\Sigma \beta$ различались на два порядка величины. Из-за низких концентраций определить ${ }^{241} \mathrm{Am}$ и ${ }^{154} \mathrm{Eu}$ во всех отобранных пробах на полупроводниковом спектрометре не удалось. По результатам отдельных

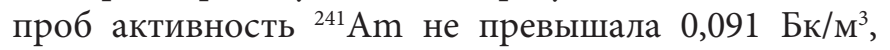
a ${ }^{154} \mathrm{Eu}-0,0097$ Бк/ $\mathrm{M}^{3}$.

Усредненные значения концентраций ${ }^{137} \mathrm{Cs}$ и $\Sigma \beta$ за весь период наблюдения составили 0,42 и 1,8 Бк/ ${ }^{3}$ соответственно, что на порядок величины меньше значения, полученного при наблюдениях в 20102011 гг. [2].

В 2017-2018 гг. среднее значение отношений концентраций ${ }^{137} \mathrm{Cs} / \Sigma \beta=0,33$. Из полученной величины отношения следует, что вклад ${ }^{137} \mathrm{Cs}$ в сумму бетаизлучающих нуклидов-продуктов Чернобыльской аварии составлял 33 \%. Причем в 2017 г. этот вклад составил 37 \%, а в 2018 г. снизился до 27 \%. Для сравнения, в период наблюдений в 2010-2011 гг. вклад ${ }^{137} \mathrm{Cs}$ в сумму бета-излучающих нуклидов-продуктов Чернобыльской аварии составлял лишь $13 \%$.

Динамика объемной активности аэрозолей-носителей ${ }^{137} \mathrm{Cs}$ в воздухе помещения 012/7 и значения относительной влажности, наблюдаемые в периоды пробоотборов, представлены на рис. 4. Относительная влажность воздуха в помещении 012/7 в период наблюдения варьировала от 45 до $97 \%$.

Для сравнения, в период наблюдений в 2010-2011 гг. относительная влажность воздуха в помещении 012/7 варьировала от 30 до 85 \%.

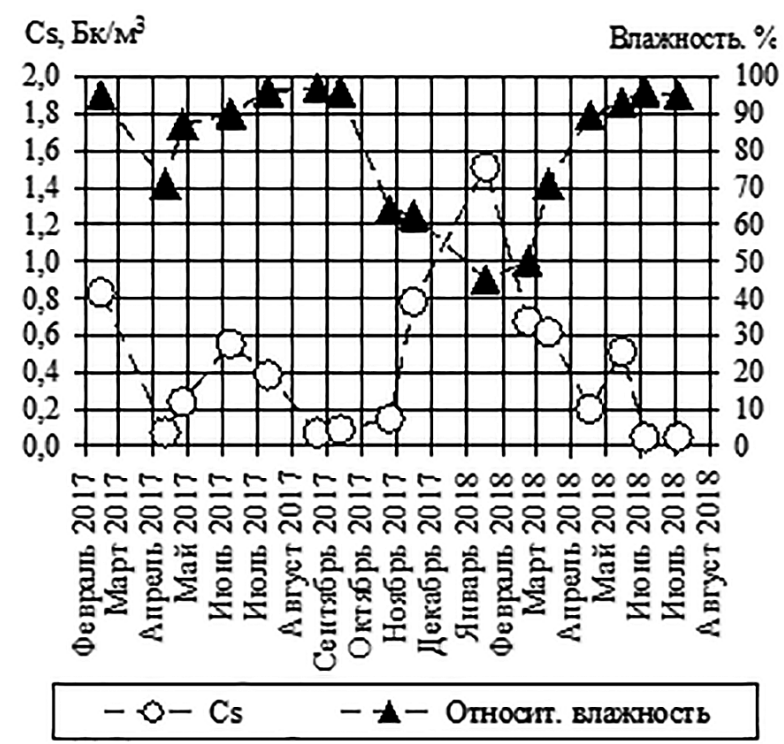

Рис. 4. Объемная активность аэрозолей-носителей

${ }^{137} \mathrm{Cs}$ и относительная влажность в помещении 012/7 в 2017-2018 гг.
Наиболее низкуювлажность (45-50 \%) наблюдали в январе 2017 г. и феврале 2018 г. Высокая влажность (96-97 \%) зафиксирована в июле-сентябре 2017 г. и в июне-июле 2018 г. (95-96 \%), когда среднесуточная температура в атмосфере окружающей среды достигала $20-21^{\circ} \mathrm{C}$.

В отличие от влажности среднесуточная температура воздуха в помещении 012/7 была стабильная. В холодный период года она опускалась от 13 до 9 'C, а в теплый период, когда происходил прогрев объекта «Укрытие», возрастала до $12-13{ }^{\circ} \mathrm{C}$. Такой режим обеспечивался огромной массой бетонных и металлических сооружений объекта «Укрытие» и расположением помещения 012/7 на высотной отметке 0 м, т. е. в подвале, где воздухообмен был незначительный.

Как следует из рис. 4, сравнительно малые значения влажности воздуха соответствовали в большинстве случаев высокой концентрации радиоактивного аэрозоля. Высокие значения влажности совпали по времени с низкими значениями концентрации радиоактивного аэрозоля.

Проба аэрозоля, отобранная 15 февраля 2017 г., после гамма-спектрометрических измерений была проанализирована радиохимическим методом. Полученные результаты с неопределенностью измерения \pm (10-30) \% приведены в табл. 2.

Таблица 2. Радионуклидный состав

(Бк, на дату отбора) пробы аэрозоля из помещения 012/7, отобранной 15.02.2017 г.

\begin{tabular}{|l|l|}
\hline${ }^{90} \mathrm{Sr}$ & $160 \pm 40$ \\
\hline${ }^{137} \mathrm{Cs}$ & $83 \pm 10$ \\
\hline${ }^{154} \mathrm{Eu}$ & $0,83 \pm 0,18$ \\
\hline${ }^{238} \mathrm{Pu}$ & $0,92 \pm 0,10$ \\
\hline${ }^{239+240} \mathrm{Pu}$ & $2,5 \pm 0,05$ \\
\hline${ }^{241} \mathrm{Am}$ & $6,4 \pm 0,65$ \\
\hline${ }^{244} \mathrm{Cm}$ & $0,097 \pm 0,02$ \\
\hline
\end{tabular}

Для сопоставления радионуклидных составов аэрозоля и скопления лавоподобных топливосодержащих материалов были проанализированы несколько гранул лавовой коры из южного края скопления.

Результаты их гамма-спектрометрии и радиохимического анализа по состоянию на 1 сентября 2018 г. приведены в табл. 3. 
Таблица 3. Содержание радионуклидов (МБк/г) в гранулах ЛТСМ из помещения 012/7

\begin{tabular}{|l|l|}
\hline${ }^{90} \mathrm{Sr}$ & $31 \pm 9,3$ \\
\hline${ }^{137} \mathrm{Cs}$ & $18 \pm 2,4$ \\
\hline${ }^{154} \mathrm{Eu}$ & $0,22 \pm 0,055$ \\
\hline${ }^{155} \mathrm{Eu}$ & $0,026 \pm 0,008$ \\
\hline${ }^{241} \mathrm{Am}$ & $2,0 \pm 0,29$ \\
\hline${ }^{238} \mathrm{Pu}$ & $0,44 \pm 0,093$ \\
\hline${ }^{239+240} \mathrm{Pu}$ & $0,98 \pm 0,02$ \\
\hline
\end{tabular}

По данным, приведенным в табл. 1 и 3, рассчитаны усредненные за 2017-2018 гг. соотношения радионуклидов в аэрозолях, а также аналогичные соотношения в гранулах ЛТСМ (табл. 4).

Таблица 4. Соотношения радионуклидов по результатам гамма-спектрометрии

\begin{tabular}{|l|c|c|}
\hline \multicolumn{1}{|c|}{ Объект } & $\begin{array}{c}\text { Аэрозоль } \\
2017-2018 \text { гг. }\end{array}$ & $\begin{array}{c}\text { Гранулы ЛТСМ } \\
\text { (на 01.09.18) }\end{array}$ \\
\hline${ }^{137} \mathrm{Cs} /{ }^{241} \mathrm{Am}$ & 20 & $9,0 \pm 1,8$ \\
\hline${ }^{137} \mathrm{Cs} /{ }^{154} \mathrm{Eu}$ & 127 & $82 \pm 16$ \\
\hline${ }^{241} \mathrm{Am} /{ }^{154} \mathrm{Eu}$ & 8,3 & $9,1 \pm 1,8$ \\
\hline
\end{tabular}

Из табл. 4 видно, что в аэрозолях величины отношений ${ }^{137} \mathrm{Cs} /{ }^{241} \mathrm{Am}$ и ${ }^{137} \mathrm{Cs} /{ }^{154} \mathrm{Eu}$ существенно больше, чем в гранулах лавовой корки. Из этого следует, что аэрозоль в помещении 012/7 в период наблюдения был существенно обогащен радиоцезием, чего в 2010-2011 гг. не наблюдалось. Установленные соотношения ${ }^{137} \mathrm{Cs} /{ }^{154} \mathrm{Eu} \mathrm{и}{ }^{137} \mathrm{Cs} /{ }^{241} \mathrm{Am}$ показывают, что в помещение в 2017-2018 гг. периодически поступали аэрозоли-носители радиоцезия от иных источников, находящихся, вероятно, вне помещения. В отличие от цезия отношения концентраций труднолетучих радиоизотопов в аэрозолях и гранулах из скопления ЛТСМ имеют близкие значения (см. табл. 4).

По результатам радиохимических анализов были получены соотношения активностей нуклидов в аэрозольной пробе от 15.02.17 и гранулах ЛТСМ (табл. 5). Соотношения радионуклидов в пробе аэрозоля представлены в пересчете на 01.09.18.

Из табл. 5 следует, что соотношения радионуклидов в пробе аэрозоля и в гранулах из скопления ЛТСМ имеют близкие значения. Расхождения результатов связаны как с неопределенностью измерения, так и неоднородностью состава ЛТСМ в помещении 012/7.
Таблица 5. Соотношения радионуклидов по результатам радиохимических анализов (в пересчете на 01.09.18)

\begin{tabular}{|l|c|c|}
\hline \multicolumn{1}{|c|}{ Объект } & Аэрозоль & Гранулы \\
\hline${ }^{241} \mathrm{Am} /{ }^{154} \mathrm{Eu}$ & 8,9 & 9,1 \\
\hline${ }^{241} \mathrm{Am} /{ }^{238} \mathrm{Pu}$ & 7,1 & 4,5 \\
\hline${ }^{241} \mathrm{Am} /{ }^{239+240} \mathrm{Pu}$ & 2,6 & 2,0 \\
\hline${ }^{90} \mathrm{Sr} /{ }^{241} \mathrm{Am}$ & 25 & 16 \\
\hline${ }^{137} \mathrm{Cs} / \Sigma \beta$ & 0,21 & 0,22 \\
\hline
\end{tabular}

На последний фактор было обращено внимание еще в публикациях $[2,5]$. Таким образом, отношения концентраций радиоизотопов в аэрозолях позволяют сделать вывод о том, что в помещении 012/7 вследствие эрозии поверхности ЛТСМ происходит генерация радиоактивного аэрозоля, который попадает в воздушную среду помещения. Этот механизм подтверждается результатами определения дисперсности аэрозольных частиц, приведенными в работе [2].

За период март 2017 г. - июль 2018 г. был выполнен отбор 9 проб выпадений радиоактивного аэрозоля в помещении 012/7.

Результаты гамма-спектрометрического анализа проб выпадений радиоактивного аэрозоля в помещении 012/7 представлены в табл. 6.

Как видно из данных табл. 6, за весь период наблюдений величина $\Sigma \beta$ варьировалав диапазоне 240 -

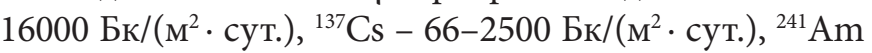

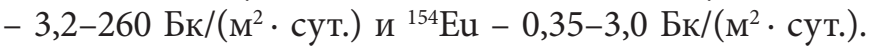
Таким образом, минимальные и максимальные значения различались на два порядка величины. При этом максимальная плотность выпадения аэрозоля наблюдалась с 4 октября по 1 ноября 2017 г. Однако большинство результатов экспонирования планшетов в 2017 г. и до февраля 2018 г. находилось в узких диапазонах значений: $\Sigma \beta-1100-2700,{ }^{137} \mathrm{Cs}-210-410,{ }^{241} \mathrm{Am}-17-43$ и ${ }^{154} \mathrm{Eu}-2-5$ Бк/(м ${ }^{2}$ суут.). Из этого следует, что в этот период в помещении 012/7 сохранялась устойчивая повышенная плотность выпадения аэрозоля по сравнению с предшествующим периодом экспонирования планшета. Необходимо отметить, что экспонирование с 08.10.14 по 22.04.17 пришлось в основном на период до надвижки «Арки» НБК. Из таблицы также видно, что величина плотности выпадения радиоаэрозоля в 2018 г. снизилась по сравнению с 2017 г. до значений, которые наблюдались до надвижки «Арки».

Как видно из представленных данных, за весь период наблюдений среднее значение отношения 
Таблица 6. Плотность выпадений аэрозоля в помещении 012/7

\begin{tabular}{|c|c|c|c|c|c|c|}
\hline \multirow{2}{*}{$\begin{array}{c}\text { Дата установки } \\
\text { планшета }\end{array}$} & \multirow{2}{*}{$\begin{array}{c}\text { Дата замены } \\
\text { планшета }\end{array}$} & \multirow{2}{*}{$\begin{array}{c}\text { Экспозиция, } \\
\text { сут. }\end{array}$} & \multicolumn{4}{|c|}{ Плотность выпадений, Бк/(м² · сут.) } \\
\hline & & & ${ }^{137} \mathrm{Cs}$ & ${ }^{154} \mathrm{Eu}$ & ${ }^{241} \mathrm{Am}$ & $\Sigma \beta$ \\
\hline 08.10 .14 & 22.03 .17 & 896 & 68 & 0,54 & 4,5 & $3,1 \cdot 10^{2}$ \\
\hline 22.03 .17 & 06.07 .17 & 106 & $4,1 \cdot 10^{2}$ & 5,0 & 43 & $2,1 \cdot 10^{3}$ \\
\hline 06.07 .17 & 03.08 .17 & 28 & $3,7 \cdot 10^{2}$ & 4,8 & 38 & $2,4 \cdot 10^{3}$ \\
\hline 03.08 .17 & 06.0917 & 34 & $3,0 \cdot 10^{2}$ & 3,2 & 29 & $1,9 \cdot 10^{3}$ \\
\hline 06.08 .17 & 04.10 .17 & 28 & $3,0 \cdot 10^{2}$ & 3,3 & 29 & $1,8 \cdot 10^{3}$ \\
\hline 04.1017 & 01.11 .17 & 28 & $2,5 \cdot 10^{3}$ & 30 & $2,6 \cdot 10^{2}$ & $1,2 \cdot 10^{4}$ \\
\hline 01.11 .17 & 06.02 .18 & 97 & $2,1 \cdot 10^{2}$ & 2,0 & 17 & $1,0 \cdot 10^{3}$ \\
\hline 06.02 .18 & 15.05 .18 & 98 & 71 & 0,35 & 3,2 & $2,4 \cdot 10^{2}$ \\
\hline 15.05 .18 & 04.07.18 & 50 & 66 & 0,37 & 4,3 & $2,9 \cdot 10^{2}$ \\
\hline
\end{tabular}

В табл. 7 представлены результаты гамма-спектрометрических измерений и радиохимического анализа проб выпадения аэрозоля в помещении 012/7.

Таблица 7. Радионуклидный состав аэрозольных выпадений в помещении 012/7 объекта «Укрытие»

\begin{tabular}{|c|c|c|c|c|c|c|c|c|c|}
\hline \multirow{2}{*}{$\begin{array}{l}\text { Даты установки- } \\
\text { снятия планшета }\end{array}$} & \multirow{2}{*}{$\begin{array}{l}\text { Экспози- } \\
\text { ция, сут. }\end{array}$} & \multicolumn{7}{|c|}{ Плотность выпадения аэрозоля, Бк/(м² · сут.) } & \multirow{2}{*}{$\begin{array}{c}\mathrm{U}, \\
\left.\text { мкг/(} \mathrm{M}^{2} \cdot \text { сут. }\right)\end{array}$} \\
\hline & & ${ }^{137} \mathrm{Cs}$ & ${ }^{154} \mathrm{Eu}$ & ${ }^{90} \mathrm{Sr}$ & ${ }^{238} \mathrm{Pu}$ & ${ }^{239+240} \mathrm{Pu}$ & ${ }^{241} \mathrm{Am}$ & ${ }^{244} \mathrm{Cm}$ & \\
\hline 09.10.14-22.03.17 & 896 & 68 & 0,54 & $1,7 \cdot 10^{2}$ & 0,97 & 2,1 & 4,5 & 0,10 & 0,65 \\
\hline 22.03.17-06.07.17 & 106 & $4,1 \cdot 10^{2}$ & 5,0 & $8,2 \cdot 10^{2}$ & 7,1 & 17 & 43 & 0,79 & - \\
\hline $04.10 .17-01.11 .17$ & 28 & $2,5 \cdot 10^{3}$ & 30 & $4,8 \cdot 10^{3}$ & 56 & $1,2 \cdot 102$ & $2,6 \cdot 10^{2}$ & 4,3 & 0,96 \\
\hline $01.11 .17-06.02 .18$ & 97 & $2,1 \cdot 10^{2}$ & 2,0 & $4,0 \cdot 10^{2}$ & 2,8 & 5,7 & 17 & 0,28 & 0,70 \\
\hline
\end{tabular}

По данным, приведенным в табл. 6 и 7, рассчитаны усредненные за 2017-2018 гг. соотношения радионуклидов в выпадениях аэрозоля в помещении 012/7 (табл. 8).

Таблица 8. Соотношения радионуклидов в выпадениях аэрозоля в помещении 012/7

\begin{tabular}{|l|c|c|c|c|c|c|c|}
\hline $\begin{array}{c}\text { Дата установки-снятия } \\
\text { планшета }\end{array}$ & ${ }^{137} \mathrm{Cs} /{ }^{154} \mathrm{Eu}$ & ${ }^{137} \mathrm{Cs} /{ }^{241} \mathrm{Am}$ & ${ }^{241} \mathrm{Am} /{ }^{154} \mathrm{Eu}$ & ${ }^{90} \mathrm{Sr} /{ }^{241} \mathrm{Am}$ & ${ }^{241} \mathrm{Am} /{ }^{238} \mathrm{Pu}$ & ${ }^{241} \mathrm{Am} /{ }^{239+240} \mathrm{Pu}$ & ${ }^{137} \mathrm{Cs} / \Sigma \beta$ \\
\hline $08.10 .14-22.03 .17$ & 130 & 15 & 8,3 & 38 & 4,6 & 2,1 \\
\hline $22.03-06.07 .17$ & 82 & 9,4 & 9,1 & 19 & 6,1 & 0,22 \\
\hline $06.07-03.08 .17$ & 77 & 9,7 & 7,7 & - & - & - & 0,20 \\
\hline $03.08-06.09 .17$ & 93 & 10 & 9,1 & - & - & - & 0,16 \\
\hline $06.09-04.10 .17$ & 89 & 10 & 8,3 & - & - & 0,16 \\
\hline $04.10-01.11 .17$ & 83 & 9,6 & 8,3 & 18 & 4,6 & 2,2 & 0,21 \\
\hline $01.11 .17-06.02 .18$ & 107 & 12 & 8,8 & 24 & 6,1 & 3,0 & 0,21 \\
\hline $06.02-15.05 .18$ & 199 & 22 & 9,0 & - & - & - & 0,30 \\
\hline $15.05-04.07 .18$ & 178 & 15 & 12 & - & - & - & 0,23 \\
\hline $\begin{array}{l}\text { Среднее значение за пе- } \\
\text { риод 22.03.17-06.02.18 }\end{array}$ & 89 & 10 & 8,6 & 20 & 5,6 & 4,1 \\
\hline $\begin{array}{l}\text { Среднее значение за пе- } \\
\text { риод 06.02-04.07.18 }\end{array}$ & 189 & 19 & 10,5 & - & - & - \\
\hline $\begin{array}{l}\text { Среднее значение за 2017- } \\
\text { 2018 гг. }\end{array}$ & 123 & 13 & 9,1 & - & & - \\
\hline
\end{tabular}


концентраций ${ }^{137} \mathrm{Cs} / \Sigma \beta=0,20$ (при минимальном значении 0,15 и максимальном 0,30$),{ }^{137} \mathrm{Cs} /{ }^{241} \mathrm{Am}$ $=13$ (минимум 9,4, максимум 22), ${ }^{137} \mathrm{Cs} /{ }^{154} \mathrm{Eu}=$ 123 (минимум 82, максимум 199) и ${ }^{241} \mathrm{Am} /{ }^{154} \mathrm{Eu}=$ 9,1 (минимум 7,7, максимум 12). Из полученной средней величины ${ }^{137} \mathrm{Cs} / \Sigma \beta$ следует, что вклад ${ }^{137} \mathrm{Cs}$ в сумму бета-излучающих нуклидов-продуктов Чернобыльской аварии составлял $20 \%$.

Из табл. 8 следует, что соотношения радионуклидов в пробах выпадений аэрозоля и в гранулах из скопления ЛТСМ в помещении 012/7 (см. табл. 4 и 5) имеют близкие значения. Расхождения результатов связаны, как уже отмечалось ранее, с неопределенностью измерения и неоднородностью состава ЛТСМ. Кроме того, из сопоставления соотношений ${ }^{137} \mathrm{Cs} /{ }^{154} \mathrm{Eu} \mathrm{и}{ }^{137} \mathrm{Cs} /{ }^{241} \mathrm{Am}$ в ЛТСМ с радионуклидным составом выпадений в помещении следует, что на протяжении 2018 г. радиоаэрозольные выпадения обогащены ${ }^{137} \mathrm{Cs}$ относительно состава находящихся здесь ЛТСМ. Поскольку ЛТСМ были обеднены радиоцезием в процессе образования лавы и ее растекания по помещениям объекта «Укрытие», то источниками дополнительного цезия являются аэрозоли-носители ${ }^{137} \mathrm{Cs}$. Эти аэрозоли, вероятно, образуются в результате деструкции поверхностей, на которые ранее сорбировались частицы-носители конденсационного цезия.

Представленные данные показывают, что источниками радиоаэрозольного выпадения в помещении 012/7 являются в основном аэрозоли, которые генерируются с поверхности ЛТСМ из этого помещения. Некоторую долю выпадений формируют аэрозолиносители радиоцезия от иных источников, возможно, находящихся вне помещения.

\section{Выводы}

1. В 2017-2018 гг. в помещении 012/7 объекта «Укрытие» отобраны и проанализированы 16 проб радиоактивных аэрозолей - продуктов Чернобыльской аварии и 9 проб аэрозольных выпадений, при этом величина $\Sigma \beta$ варьировала в диапазоне $0,088-5,8$ Бк/ $\mathrm{m}^{3}$, ${ }^{137} \mathrm{Cs}-0,047-1,5$ Бк/$/ \mathrm{M}^{3}$, активность ${ }^{241} \mathrm{Am}$ не превышала $0,091 \mathrm{Б \kappa} / \mathrm{M}^{3}, \mathrm{a}^{154} \mathrm{Eu}-0,0097 \mathrm{Б \kappa} / \mathrm{M}^{3}$. Таким образом, объемная активность аэрозоля в помещении в 2017-2018 гг. на порядок величины меньше значений, полученных при наблюдениях в 2010-2011 гг., что связано, по-видимому, с повышением влажности в помещении.

2. Соотношения радионуклидов в пробах аэрозоля воздуха и его выпадения, а также в гранулах из скопления ЛТСМ в помещении 012/7 имеют близкие значения, что свидетельствует о разрушении лавы и спонтанном переходе продуктов деструкции в аэрозольное состояние.

\section{Список использованной литературы}

1. Ядерное топливо в объекте «Укрытие» / Р.Э. Арутюнян, Л. А. Большов, А. А. Боровой и др. - Москва : Наука, 2010. $-240 \mathrm{c}$.

2. Огородников Б. И. Аэрозоли - свидетели разрушения лавообразных топливосодержащих материалов в объекте «Укрытие» / Б. И. Огородников, В. Е. Хан, В. П. Ковальчук // Проблеми безпеки атомних електростанцій і Чорнобиля. - 2013. - Вип. 20. - С. 94-106.

3. Лавообразные топливосодержащие материалы в бассейне-барботере и парораспределительном коридоpe 4-го блока Чернобыльской АЭС / А. А. Боровой, А. А. Ключников, В. А. Краснов и др. // Проблеми Чорнобиля. - 2001 - Вип. 7. - С. 181-193.

4. Объект «Укрытие»: 1986-2006 / А. А. Ключников, В. А. Краснов, В. М. Рудько, В. Н. Щербин. - Чернобыль : Ин-т проблем безопасности АЭС НАН Украины, 2006. $168 \mathrm{c}$.

5. Пазухин Э. М. Лавообразные топливосодержащие массы 4-го блока Чернобыльской АЭС: топография, физико-химические свойства, сценарий образования / Э. М. Пазухин // Радиохимия. - 1994. - Т. 36. - № 2. C. $97-142$.

О. С. Лагуненко, В. Є. Хан, О. О. Одінцов, В. П. Ковальчук, Т. А. Кравчук, О. К. Калиновський, В. О. Кашпур, О. А. Свирид, А. В. Ткач, С. В. Юрчук

Інститут проблем безпеки АЕС НАН України, вул. Кірова, 36а, м. Чорнобиль, 07270, Україна

Радіоактивні аерозолі біля скупчення лавоподібних паливовмісних матеріалів у приміщенні 012/7 об’єкта «Укриття» у 2017-2018 рр.

Представлено радіонуклідний склад і об’ємні активності аерозолів та їхні випадіння у приміщенні 012/7 об'єкта «Укриття» у 2017-2018 рр. Проби відбирали в 0,5 м від південного краю скупчення лавоподібних паливовмісних матеріалів (ЛПВМ). Установлено, що сумарна концентрація аерозолів-носіїв ${ }^{90} \mathrm{Sr}+{ }^{90} \mathrm{Y} \mathrm{i}{ }^{137} \mathrm{Cs}$ коливалася в діапазоні 0,1-6 Бк/ $\mathrm{m}^{3}$. При цьому на частку ${ }^{137} \mathrm{Cs}$ припадало $33 \%$. Гамма-спектрометричні вимірювання та радіохімічні аналізи показали, що середні співвідношення радіонуклідів-продуктів аварії 4-го блока Чорнобильської атомної електро- 
станції в аерозольних пробах і зразках ЛПВМ практично ідентичні. Це свідчить про те, що відбувається деструкція ЛПВМ і частковий перехід матеріалів в аерозольний стан.

Ключові слова: об’єкт «Укриття», лавоподібні паливовмісні матеріали, аерозолі, об’ємна активність, співвідношення радіонуклідів.

\section{A. S. Lagunenko, V. E. Khan, O. O. Odintsov, V. P. Kovalchuk, T. A. Kravchuk, A. K. Kalinovskiy, V. O. Kashpur, O. A. Svirid, A.V. Tkach, S. V. Yurchuk}

Institute for Safety Problems of Nuclear Power Plants, NAS of Ukraine, Kirova str., 36a, Chornobyl, 07270, Ukraine

\section{Radioactive Aerosols in 2017-2018 near Lava-Like Fuel Contained Materials in Premise 012/7 of the Shelter Object}

The data on radionuclide composition and volumetric activity of aerosols sampled in 2017-2018 in the room 012/7 of the Shelter object, into which the lava-like fuel-containing materials (LFCMs) flew after the accident, are presented. All the samples were taken from one point at around $50-\mathrm{cm}$ distance from southern edge of LFCM cluster footing. Relative air humidity in the room $012 / 7$, depending on a year season, was varying from 45 to $97 \%$. During a day, it sometimes was changing at 5-10\%. Differing from the humidity, air temperature in the room $012 / 7$ was very stable. In cold year period, it was at the level of $12-13{ }^{\circ} \mathrm{C}$, and in the warm period, it was fluctuating within the range of around $9^{\circ} \mathrm{C}$. No daily changes were observed. It was stated that concentration of beta-emitting aerosol-carriers $\left({ }^{90} \mathrm{Sr}+{ }^{90} \mathrm{Y}\right.$ and $\left.{ }^{137} \mathrm{Cs}\right)$ was fluctuating within the range of $0.1-6 \mathrm{~Bq} / \mathrm{m}^{3}$. Besides, ${ }^{137} \mathrm{Cs}$ share made $33 \%$. On top of that, in 2017 year this contribution made $37 \%$, and in 2018 it dropped to $27 \%$. As a comparison, during survey period of 2010-2011 years, ${ }^{137}$ Cs contribution in the sum of beta-emitting nuclides of Chernobyl accident products made $13 \%$ only. When comparing the ratios of ${ }^{137} \mathrm{Cs} /{ }^{154} \mathrm{Eu}$ и ${ }^{137} \mathrm{Cs} /{ }^{241} \mathrm{Am}$ in LFCM with radionuclide content of aerosol releases in the room $012 / 7$ it follows that during the year of 2018 the aerosol precipitation was enriched by ${ }^{137} \mathrm{Cs}$ relatively to the content of LFCM available in this place. Since the LFCM were depleted by radioactive cesium during lava formation process and their spreading along the rooms of Shelter Object, thus, a source of additional cesium were ${ }^{137} \mathrm{Cs}$ aerosol-carriers. These aerosols were, apparently, produced as result of surfaces degradation, on which condensation cesium's particle-carriers were earlier sorbed. Gamma-spectrometric measurements and radiochemical analyses have demonstrated that the content and ratio of radionuclides-products of ChNPP Unit 4 accident in aerosol samples and LFCM specimens were, practically, identical. It testifies that LFCM destruction and particular transfer of materials in aerosol state occurs.

Keywords: Shelter object, aerosols, volume activity, lava-like fuel-containing materials, radionuclide ratios.

\section{References}

1. Arutyunyan R. E., Bolshov L. A., Borovoi A. A., et al. (2010) Yadernoe toplivo v obekte "Ukrytie" [Nuclear fuel in the Shelter object]. Moscow: Nauka, 240 p. (in Russ.)

2. Ogorodnikov B. I., Khan V. E., Kovalchuk V. P. (2013) Aerozoli - svideteli razrusheniya lavoobraznykh toplivosoderzhashchikh materialov v obekte "Ukrytie" [Aerosols as evidences of destruction in the Shelter object]. Problemy bezpeky atomnykh electrostantsiy $i$ Chornobylya [Problems of nuclear power plants' safety and of Chornobyl], vol. 20, pp. 94-106. (in Russ.)

3. Borovoy A. A., Lagunenko A. S., Pazukhin E. M. (2000) Novye otsenki kolichestva yadernogo topliva, nakhodyashchegosya na nizhnikh otmetkakh obekta "Ukrytie" [The new estimations of the nuclear fuel quantity allocated into the Shelter object low floor levels]. Problemy Chornobylya [Problems of Chornobyl], vol. 6, pp. 13-16. (in Russ.)

4. Klyuchnikov A. A., Krasnov V. A., Rudko V. M., Scherbin V. N. (2006) "Ukryttya" object: 1986 - 2006 [The Shelter object]. Chornobyl: Institute for Safety Problems of NPP, NAS of Ukraine, 168 p. (in Russ.)

5. Pazukhin E. M. (1994) Lava fuel containing materials of the Chernobyl NPP unit 4: topography, physical-chemical properties, scenario of formation. Radiohimiya [Radiochemistry], vol. 36, no. 2, pp. 97-142. (in Russ.)

Надійшла 17.09.2018

Received 17.092018 


\section{Правила для авторів}

\section{Загальні вимоги}

1. Редакція збірника «Ядерна енергетика та довкілля» приймає раніше неопубліковані авторські статті, що відповідають профілю видання та мають наукове та практичне значення. Тексти статей та всі матеріали до них повинні бути ретельно відредаговані та перевірені.

2. Статті, які є результатами робіт, проведених в інших організаціях, повинні мати супровідний документ від цих організацій. Разом зі статтею до редакції журналу має бути поданий документ про можливість відкритої публікації матеріалів та згоду авторів на поширення їх через мережу Інтернет.

3. Матеріали, що надходять до редакції для публікування, проходять обов'язкове рецензування. Зауваження рецензентів направляють розробнику матеріалів без вказівки імен рецензентів. Після отримання рецензій і відповіді автора редакційна рада ухвалює рішення про можливість і порядок публікації роботи. Редакція залишає за собою право відхилити статтю без зазначення причин, при цьому рукописи не повертаються авторам. Незначні правки стилістичного, номенклатурного та формального характеру вносять до тексту без узгодження з автором.

4. Рукопис статті журналу варто подати в паперовому вигляді з підписами всіх авторів на останній сторінці, а також електронної версії (на електронному носії або електронною поштою). Стаття подається в одному примірнику українською, російською або англійською мовою.

5. Електронна версія статті повинна бути створена за допомогою текстового редактора Microsoft Word 3 урахуванням таких вимог: шрифт - Times New Roman; кегель - 11 пт; міжрядковий інтервал - 1,5; розстановка переносів - переносів немає; форматування - по ширині; колір шрифту - чорний; абзацний відступ - 1,5 см; розміри полів, мм: зліва - 24 мм, справа - 16 мм, зверху - 22 мм, знизу - 28 мм.

Розмір шрифту надписів на рисунках і підписів до них, а також і таблиць - 10 пт.

6. Загальний обсяг статті разом з графічними матеріалами не повинен перевищувати 15 сторінок формату А4.

7. На титулі статті має бути представлено ії УДК.

Українською, російською та англійською мовами слід навести:

прізвище, ім'я та по батькові автора;

його учений ступінь, звання, посаду, ідентифікатор ORCID;

повну назва організації, де працює автор, і її поштову адресу;

назву статті;

анотацію та ключові слова.

8. У разі співавторства додатково слід вказати прізвище, ім'я та по батькові автора, відповідального за контактування з редакцією, його телефон і адресу електронної пошти.

9. Графічний матеріал (чорно-білий) подають окремими від тексту файлами у форматі EPS, TIFF або JPG з густиною точок на дюйм не менше 300 dpi. Зображення повинні бути якомога зрозумілішими. Назви та докладне пояснення змісту слід наводити в підписах під рисунками, а не на самих ілюстраціях. Текст не повинен повторювати інформацію, представлену в рисунках, він має тільки давати основні висновки за ними та резюмувати інформацію. Якщо рисунки мають малу кількість даних, їх варто замінити описом у тексті. Якщо рисунок складається з кількох підрисунків (a, 6, в, ...), то підпис до рисунка має містити опис кожного з підрисунків.

Графіки повинні відображати великі обсяги даних ясно і зрозуміло. Оформляючи в статті графіки, автор має переконатися, що в них підписано всі осі, вказано всі одиниці виміру для величин, підписано всі криві й масиви даних.

Схеми допомагають визначити ключові деталі в процесі, тому мають бути позбавлені зайвої інформації. 
Оформляючи схему, потрібно підписати всі ключові елементи й навести додаткові пояснення в ії заголовку та основному тексті.

10. Таблиці нумерують послідовно, відповідно до першого згадування про них у тексті. Перед кожною таблицею повинна стояти іiі назва. Слід розшифрувати всі нестандартні абревіатури у виносках, використовуючи таку послідовність символів: *, **. Слід упевнитися, що кожна таблиця процитована в тексті.

11. Формули створюють у формульному редакторі MathType Equation або MS Equation та нумерують у круглих дужках з правого боку. Грецькі і кириличні літери в формулах варто набирати прямим шрифтом (опція «текст»), латинські - курсивом. Позначення величин і символи в тексті і таблицях варто набирати як елементи тексту (а не як об’єкти формульного редактора).

12. Посилання на рисунок, графік, схему або таблицю є обов'язковим у тексті статті та згадується безпосередньо перед рисунком, графіком, схемою або таблицею.

13. Скорочення слів, словосполучень, назв, термінів, за винятком загальноприйнятих, можливе тільки після їх повного першого згадування в тексті. Далі таке слово або формулювання слід вживати лише в скороченому вигляді.

14. Одиниці вимірювання мають бути вказані у відповідних метричних одиницях або в їх десяткових кратних одиницях.

15. Матеріали, які не відповідають зазначеним вимогам, редакцією не розглядаються.

16. Виплата авторського гонорару не передбачається.

\section{Структура та зміст статті}

1. Стаття повинна бути побудована за традиційним для світової науковоїперіодики планом: структурована за розділами та завершуватися конкретними висновками, в яких у лаконічній формі викладено результати роботи та пропозиції автора, що випливають із викладеного матеріалу.

2. Назва статті повинна відображати основну ідею дослідження; акцентувати на важливості дослідження; бути лаконічною; зацікавлювати читачів.

3. Прізвища авторів англійською мовою подаються відповідно до прийнятої міжнародної системи транслітерації (з української - відповідно до Постанови Кабінету Міністрів України № 55 від 27.01.2010 «Про впорядкування транслітерації українського алфавіту латиницею», з російської - відповідно до «Системы транслитерации Библиотеки конгресса США»). Наведення прізвища у різних системах транслітерації призводить до дублювання профілів (ідентифікаторів) автора в базі даних (профіль створюється автоматично в разі збігу його даних по двох публікаціях).

4. Анотація - це стисла інформація про зміст статті. Багато читачів знайомитимуться тільки з анотацію статті, тому вона має бути зрозумілою та інформативною за умови опублікування ії окремо від статті. Вона не має повторювати відомості, що містяться в заголовку.

Анотація українською та російською мовами має бути розміром приблизно 1000 знаків. Оскільки єдиним джерелом інформації щодо змісту статті для іноземних спеціалістів $є$ анотація англійською мовою, вона має бути більшою за обсягом (не менше 1800 знаків), більш структурованою та не має бути перекладним варіантом анотаціїукраїнською або російською. Оптимальним для такої анотаціїє структурування відповідно до основних елементів самої статті (актуальність, матеріали та методи, висновки тощо). Вона має бути інформативною (позбавленою загальних слів), змістовною (відображати основний зміст статті та результатів досліджень) і містити термінологію, характерну для іноземних спеціальних текстів. Неприйнятним $\epsilon$ нередагований автоматичний переклад за допомогою онлайн-сервісів.

5. Ключові слова використовуються для індексування роботи в електронних системах та мережі Інтернет. Чим краще будуть підібрані ключові слова до роботи, тим більше людей зможуть ії знайти, здійснюючи пошук за такими самими ключовими словами. Це збільшить читаність статті, а отже, підвищить ймовірність іiі цитування. Ключові слова повинні відображати зміст статті та бути конкретними у своїй предметній галузі.

6. Структура статті передбачає такі основні розділи:

вступ;

стан проблеми та аналіз літературних даних; 
постановка завдань дослідження;

матеріали дослідження, експериментальна частина;

інтерпретація результатів та їх апробація;

висновки.

Вступ має надати читачеві інформацію (зокрема довідкового характеру), необхідну для того, щоб зрозуміти, яке питання вивчалося, а також причини, з яких автор проводить дослідження. У вступі стисло потрібно відобразити передумови до проведення дослідження: подати загальне розуміння проблеми, яку автор порушив, й аргументовано обгрунтувати актуальність дослідження, описати проблему та тематику, а також навести актуальні знання, пов'язані з розглянутими науково-дослідницькими завданнями.

Стан проблеми та аналіз літературних даних дає змогу виявити «нішу», де автори проводять наукові дослідження. Розділ пишуть на основі публікацій періодичних наукових видань (книги, підручники, монографії, стандарти, звіти до таких не належать). Огляд періодики з проблеми, що досліджується автором, має охоплювати джерела не більше 10-річної давності (у галузі IT-технологій - 5-річної давності). Обов'язковим $є$ огляд закордонних наукових періодичних видань. Цей розділ є одним із найважливіших, оскільки з нього випливає, наскільки автор особисто розуміє стан проблеми, яку береться досліджувати.

У літературному огляді висвітлюють не вирішені іншими вченими частини проблеми, які досліджує автор; викладають причини цього дослідження; чітко визначають цілі дослідження, які повинні узгоджуватися 3 іншою частиною рукопису; наводять посилання на важливі джерела, які дають змогу повніше розкрити суть роботи.

Правильно підібраний літературний огляд передбачає:

цитування автором найбільш релевантних результатів попередніх досліджень і пояснення того, наскільки вони співвідносяться з поточним дослідженням;

посилання на дослідження різних дослідницьких груп;

посилання на оригінальні дослідження, а не на велику кількість оглядових статей;

максимальна користь цитат для читача (читачеві не цікаво, коли автор посилається на велику кількість своїх робіт або на інші роботи для того, щоб показати глибину своїх знань);

посилання на результати інших досліджень, які або суперечать отриманим автором результатам (якщо такі є), або підтверджують їх.

Джерела в тексті статті повинні бути відсортовані за порядком згадування.

Матеріали дослідження, експериментальна частина $€$ розділом, зі змісту якого має бути зрозуміло, як отримано всі результати. Варто описати систему дослідження (методи, методику тощо). Методи, які використовували для обробки даних, мають бути обгрунтовані (спиратися на статистику). Автор, який використав методику опублікованого дослідження, повинен послатися на неї та дати резюме процедури в тексті статті.

Результати дослідження мають бути чітко визначені, а підсумкові результати - об'єктивно підтверджені (наприклад, результатами математичного, статистичного, імітаційного моделювання, натурними експериментами, фундаментальними положеннями наукових дисциплін у відповідній предметній галузі).

Інтерпретація результатів та їх апробація передбачає приклади практичних рішень (результати чисельних експериментів, графіки, діаграми тощо) на основі отриманих автором наукових результатів. Приклади дають змогу оцінити адекватність запропонованих теоретичних рішень та їх практичну значимість. Потрібно вказати, в умовах якого виробництва були впроваджені або можуть бути впроваджені результати досліджень.

Якщо результати не є основною метою статті, їх можна узагальнити й не публікувати дані детально. Тим не менш, у разі недостатньої кількості інформації читач може втратити довіру до дослідження, припустивши, що автор приховує слабкі докази.

Висновки відображають, наскільки матеріал дослідження відповідає його цілям, сформульованим у вступі. Варто означити, чи існують альтернативні інтерпретації отриманих результатів та порівняти отримані результати з результатами інших досліджень.

Доречно вказати, як результати наукової розвідки можуть вплинути на майбутні дослідження, чи є в дослідженні обмеження. Перевірте відповідність описаних висновків отриманим даним. 


\section{7. Список використаної літератури}

Всіцитати, методи, моделі, рисунки, таблиці тощо, запозиченіз інших робіт, обов’язково супроводжуються посиланням на першоджерело.

Посилання на список літератури повинні бути пронумеровані послідовно відповідно до їх порядку у тексті. Оскільки посилання відіграють важливу роль у багатьох розділах статті, нездатність навести достатню кількість посилань на інші роботи може зменшити шанси для статті бути опублікованою. Кожна констатація факту чи опис попередніх висновків має супроводжуватися посиланням на першоджерело.

Правильне описання джерел, на які посилаються автори, є запорукою того, що цитовану публікацію буде враховано в процесі оцінювання наукової діяльності ії авторів, а отже, й організації, регіону, країни. За цитуванням журналу визначається його науковий рівень, авторитетність тощо.

3 метою включення журналу до міжнародних баз даних у статтях видання потрібно використовувати відповідні стандарти подання пристатейних списків літератури.

Після статті має бути розміщено два списки:

1) Список використаної літератури - джерела мовою оригіналу, оформлені відповідно до вимог українського стандарту бібліографічного опису ДСТУ ГОСТ 7.1:2006 «Бібліографічний запис. Бібліографічний опис. Загальні вимоги та правила складання».

2) References - той самий список літератури, де українські та російські джерела транслітеровані в латинському алфавіті та подані за допомогою міжнародної системи запису посилання American Psychological Association (APA).

\section{Оформлення бібліографічного списку «Список використаної літератури»}

1. Основним нормативним документом для оформлення списку літератури є ДСТУ ГОСТ 7.1:2006 «Бібліографічний запис. Бібліографічний опис. Загальні вимоги та правила складання».

2. Бібліографічний опис складають за такою загальною формою:

Автори. Основна назва [Загальне позначення матеріалу] = Паралельна назва : відомості, що стосуються назви / перші відомості про відповідальність ; відомості про інших осіб чи установи, які несуть інтелектуальну відповідальність за видання. - Відомості про повторність видання / Відповідальність за повторне видання. - Зона специфічних відомостей. - Місце видання : Видавництво, рік. - Фізична (кількісна) характеристика. - (Серія. Підсерія ; №, т.). - Примітки. - Стандартний номер та умови доступності.

Елементи, виділені жирним шрифтом, $є$ факультативними.

3. Бібліографічний опис кожного окремого документа складається на мові цього документа.

4. У випадках, коли документ має одного, двох, трьох авторів - у заголовку вказується прізвище тільки першого автора (спочатку прізвище, потім ініціали). За косою рискою в зоні назви та відомостей про відповідальність вказуються прізвища авторів з ініціалами (обов'язково повторюється прізвище першого автора, зазначеного у заголовку бібліографічного опису; спочатку ініціали, потім прізвище).

5. Проміжки між знаками та елементами запису є обов'язковими і використовують для розрізнення знаків граматичної і приписаної пунктуації.

6. Уніфіковані форми скорочень українською та латинською мовами: та інші (et alii) - та ін. (et. al.); i так далі (et cetera) - і т. д. (etc.); без місця (sine loco) - б. м. (s. 1.); без видавця (sine nomine) - б. в. (s. n.).

7. Джерела у списку варто розміщувати послідовно відповідно до їх порядку у тексті.

\section{Оформлення списку літератури «References»}

1. Список літератури («References») для Scopus та інших зарубіжних баз даних (БД) необхідно наводити окремим блоком, повторюючи список, наданий українською/російською мовою, незалежно від того, $є$ в ньому іноземні джерела чи немає.

2. За основу побудови посилання в списку літератури латиницею в журналі «Ядерна енергетика та довкілля» взято принципи формування бібліографічних посилань American Psychological Association (APA). Відповідно до специфіки адаптації бібліографічного опису матеріалів українською та російською мовами 
враховано рекомендації експерта бази даних Scopus О. В. Кирилової.

Бібліографічні посилання латиницею для журналу створюють за принципом, що дасть змогу зарубіжним наукометричним базам у найлегший спосіб фіксувати дані про елементи кожного посилання та забезпечити коректні показники їх цитованості.

3. В опис статті необхідно вносити всіх авторів, не скорочуючи перелік до трьох, як це рекомендовано чинними в Україні державними стандартами.

4. Деякі елементи бібліографічного опису подають курсивом, як показано на зразках нижче.

5. У випадках оформлення україно- або російськомовного джерела іншою мовою після заголовка і відомостей про видання, транслітерованих латиницею, в [квадратних дужках] вказується переклад українського (російського) заголовка разом з відомостями про видання в англійську мову.

6. Для транслітерування прізвищ авторів, назв статей, книжок, видавництв тощо варто користуватися онлайн-конвертерами окремо для українською та російської мов, посилання на які подані нижче. Ці ресурси пропонують найпоширеніші варіанти транслітерування: для української мови - згідно з чинним стандартом; для російської - відповідно до правил Держдепартаменту США. Такий підхід дозволить уніфікувати дані для міжнародних баз, адже різні системи транслітерації сприятимуть створенню різних результатів.

Онлайн-конвертер з української мови для транслітерації: http://translit.kh.ua/?passport.

Онлайн-конвертер з російської мови для транслітерації: http://ru.translit.net/?account=bgn.

1. Для україномовних і російськомовних статей, які використовують з журналів, рекомендуємо такий варіант структури бібліографічних посилань в References:

ПІБ авторів (транслітерація);

рік видання в дужках;

назва статті у варіанті, що транслітерується, і переклад назви статті англійською мовою в квадратних дужках [ ];

назва джерела (транслітерація) і переклад назви джерела англійською мовою [ ];

вихідні дані з позначеннями англійською мовою.

позначення мови оригіналу (in Russ., in Ukr.).

2. Спростити процес створення списку «References» дають змогу ресурси автоматичного формування бібліографічних описів за пропонованими стандартами. Причому описи можна створювати для різних видів публікацій (книга, стаття з журналу, інтернет-ресурс тощо). Приклади таких сайтів: http://www.easybib.com; http://www.bibme.org.

\section{Приклади}

\section{Стаття з періодичного видання}

Автор(и) (рік видання). [Переклад назви статті англійською мовою]. Транслітерована назва періодичного видання [Переклад назви видання англійською мовою], випуск (vol.), номер (no.), сторінки (pp.). (in Ukr.)/ (in Russ.)

Ogorodnikov B. I., Skorbun A. D. (2006). [On the possibility of predicting the level of aerosol activity in the ventilation system of the Shelter]. Problemy bezpeky atomnykh elektrostantsii i Chornobylia [Problems of nuclear power plants safety and of Chernobyl], vol. 4, pp. 121-124. (in Russ.)

\section{Книга}

Автор(и) (рік видання). Транслітерована назва книги [Переклад назви книги англійською мовою]. Місто: Видавництво, кількість сторінок (р.). (in Ukr.)/(in Russ.)

Nigmatulin R. I. (1987). Dinamika mnogofaznykh sred [Dynamics of multiphase media]. Moscow: Nauka Publ., 464 p. (in Russ.)

\section{Стаття зі збірника доповідей конференцій}

Автор(и) (рік видання). Транслітерована назва статті [Переклад назви статті англійською мовою]. Proceedings of the Назва конференції англійською мовою (країна, місто, дата проведення) (еds. (редактори, 
редколегія - якщо є)), Місто видання: Видавництво, сторінки (pp.). (in Ukr.)/(in Russ.)

Mikhaylov A. V. (2017). Materialnye i geometricheskie parametry toplivosoderzhashchikh mass s vysokim soderzhaniem urana v novom bezopasnom konfaynmente - Obekte «Ukrytiye» [Material and geometric parameters of fuel-containing masses with high uranium content in a new safe confinement - Shelter object]. Proceedings of the XXIV Annual scientific conference of Institute for Nuclear Research of National Academy of Sciences of Ukraine (Kyiv, April 10-13, 2017). Kyiv: Institute for Nuclear Research, pp. 122-123. (in Russ.)

\section{Автореферат дисертації}

Автор (рік видання). Транслітерована назва дисертації [Переклад назви дисертації англійською мовою] (PhD Thesis), Місто: Видавництво, кількість сторінок (р.) (in Ukr.)/(in Russ.)

Khabarova H. V. (2016). Ekolohichnyi ryzyk zabrudnennia atmosfernoho povitria vykydamy teplovykh elektrostantsii pry vykorystanni kamianoho vuhillia [Environmental risk of atmospheric air pollution by thermal power plants in case of coal using] (PhD Thesis). Kharkiv, [s. n.], 24 p. (in Ukr.)

\section{Стаття з електронного періодичного видання}

Автор(и) (рік видання). [Переклад назви статті англійською мовою]. Транслітерована назва періодичного видання [Переклад назви періодичного видання англійською мовою], випуск (vol.), номер (no.), сторінки (pp.). Available at: (електронна адреса статті) (accessed (дата відвідування сайту)). (in Ukr.)/(in Russ.)

Barbashev S. (2016). [Current status and activities to improve environmental]. Yaderna enerhetyka ta dovkillia [Nuclear power and the environment], vol. 7, no. 1, pp. 4-12. Available at: http://dnic.com.ua/_ld/0/84_1_7_2016_ Pur_2.pdf (accessed 03.12.2017). (in Russ.)

\section{Законодавчі та нормативні документи}

Вид документа та назва. Дата прийняття, номер документа. Транслітерована назва періодичного видання [Переклад назви періодичного видання англійською мовою], випуск (vol.), номер (no.), сторінки (pp.). (in Ukr.)/(in Russ.)

The Law of Ukraine "On General Principles of Further Operation and Decommissioning of Chornobyl NPP and Transformation of Ruined Fourth Power Unit of This NPP into Ecologically Safe System" of December 11, 1998, No. 309-XIV. Vidomosti Verkhovnoi Rady Ukrainy, no. 4, p. 33. (in Ukr.)

\section{Стандарт}

Код стандарта. Назва англійською мовою. Місто видання: Видавництво, рік видання, сторінки (рр.). (in Ukr.)/(in Russ.)

GOST 8.586.5-2005. Method of measurement. Measurement of flow rate and volume of liquids and gases by means of orifice devices. Moscow, Standartinform Publ., 2007. 10 p. (in Russ.)

\section{Патент}

Автор(и) (рік) Транслітерована назва патента [Переклад назви дисертації англійською мовою]. Код патента, рік.

Palkin M. V. et. al. (2006) Sposob orientirovaniia po krenu letatel'nogo apparata s opticheskoi golovkoi samonavedeniia [The way to orient on the roll of aircraft with optical homing head]. Patent RF, no. 2280590. (in Russ.) 